\title{
The Idaho National Engineering and Environmental Laboratory Source Water Assessment
}

\author{
G. Sehlke
}

March 2003

Idaho National Engineering and Environmental Laboratory Bechtel BWXT Idaho, LLC 


\title{
The Idaho National Engineering and Environmental Laboratory Source Water Assessment
}

\author{
Gerald Sehlke
}

March 2003

\section{Idaho National Engineering and Environmental Laboratory Idaho Falls, Idaho 83415}

Prepared for the

U.S. Department of Energy

Assistant Secretary for Environmental Management

Under DOE Idaho Operations Office

Contract DE-AC07-99ID13727 



\begin{abstract}
The Idaho National Engineering and Environmental Laboratory (INEEL) covers approximately $890 \mathrm{mi}^{2}$ and includes 12 public water systems that must be evaluated for Source water protection purposes under the Safe Drinking Water Act. Because of its size and location, six watersheds and five aquifers could potentially affect the INEEL's drinking water sources. Based on a preliminary evaluation of the available information, it was determined that the Big Lost River, Birch Creek, and Little Lost River Watersheds and the eastern Snake River Plain Aquifer needed to be assessed. These watersheds were delineated using the United States Geologic Survey's Hydrological Unit scheme. Well capture zones were originally estimated using the RESSQC module of the Environmental Protection Agency's Well Head Protection Area model, and the initial modeling assumptions and results were checked by running several scenarios using Modflow modeling. After a technical review, the resulting capture zones were expanded to account for the uncertainties associated with changing groundwater flow directions, a thick vadose zone, and other data uncertainties. Finally, all well capture zones at a given facility were merged to a single wellhead protection area at each facility. A contaminant source inventory was conducted, and the results were integrated with the well capture zones, watershed and aquifer information, and facility information using geographic information system technology to complete the INEEL's Source Water Assessment. Of the INEEL's 12 public water systems, three systems rated as low susceptibility (EBR-I, Main Gate, and Gun Range), and the remainder rated as moderate susceptibility. No INEEL public water system rated as high susceptibility. We are using this information to develop a source water management plan from which we will subsequently implement an INEEL-wide source water management program. The results are a very robust set of wellhead protection areas that will protect the INEEL's public water systems yet not too conservative to inhibit the INEEL from carrying out its missions.
\end{abstract}




\section{CONTENTS}

ABSTRACT

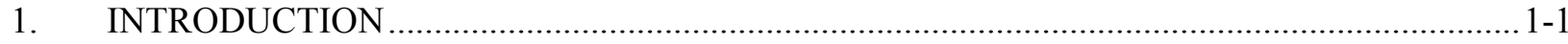

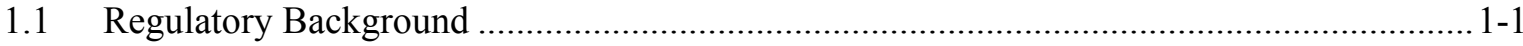

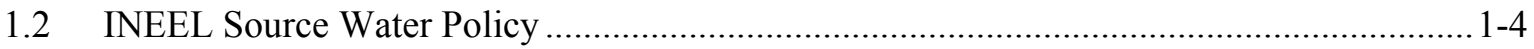

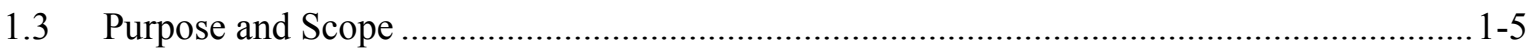

1.4 Overview of INEEL Facilities with Public Water Systems ............................................. 1-6

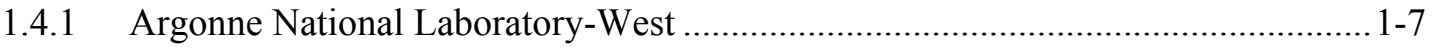

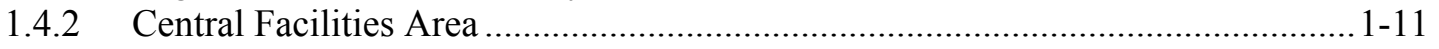

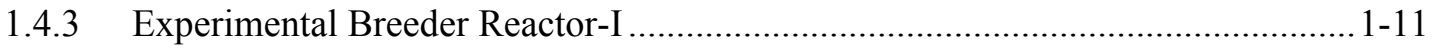

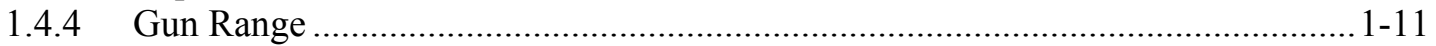

1.4.5 Idaho Nuclear Technology and Engineering Center....................................... 1-11

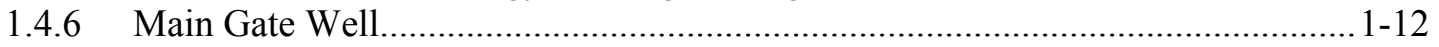

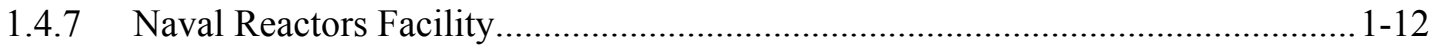

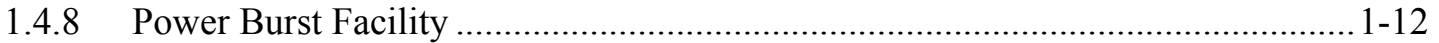

1.4.9 Radioactive Waste Management Complex .........................................................1-13

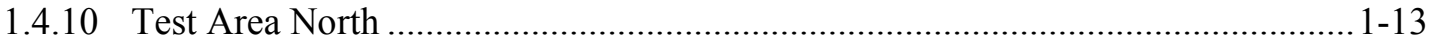

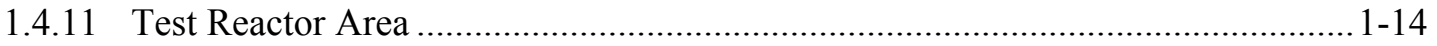

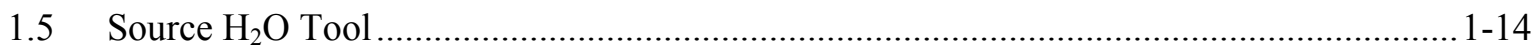

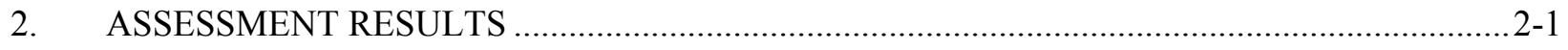

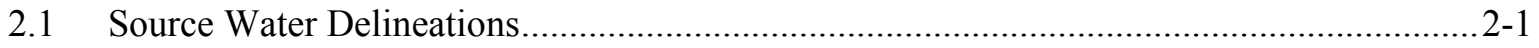

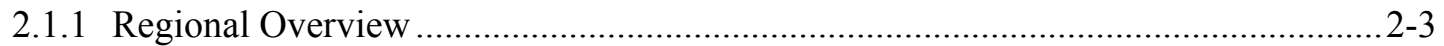

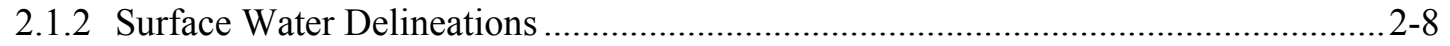

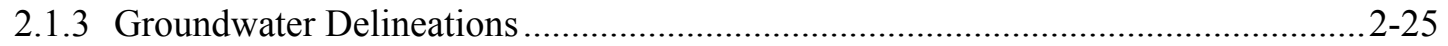

2.1.4 Facility-Specific Wellhead Protection Zones ......................................................2-32

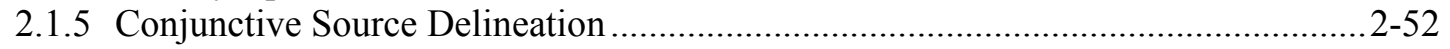

2.2 Contaminant Sources Identification and Inventory................................................... 2-56

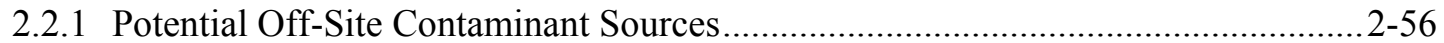

2.2.2 Potential INEEL Facility Contaminant Sources ......................................................2-63

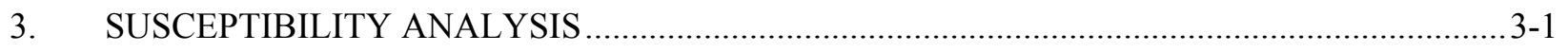

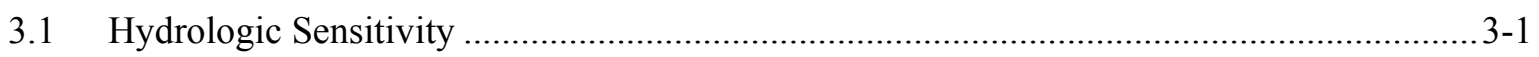

3.2 Evaluation of Potential Contaminant Sources/Land Use ................................................ 3-4 
Evaluation of System Construction......................................................................... $3-5$

3.4 Contaminants of Interest Detected In INEEL Public Water Systems ............................... 3-5

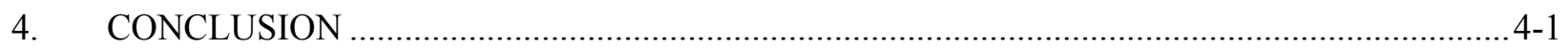

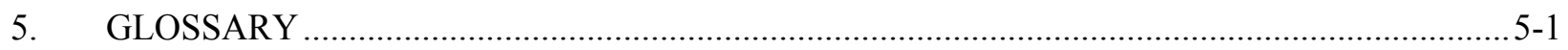

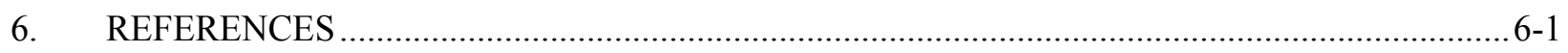

Appendix A, Facility-Specific Wellhead Protection Area Maps

Appendix B, Summary of Potential Contaminant Sources within INEEL Wellhead Protection Areas

Appendix C, As-Built Drawing for INEEL Public Water System Wells

Appendix D, Contaminants of Interest Detected in INEEL Drinking Water Samples for FY-1997-FY-2001

Appendix E, Source $\mathrm{H}_{2} \mathrm{O}$ User's Guide

\section{FIGURES}

1-1. Location of the Idaho National Engineering and Environmental Laboratory .............................. 1-2

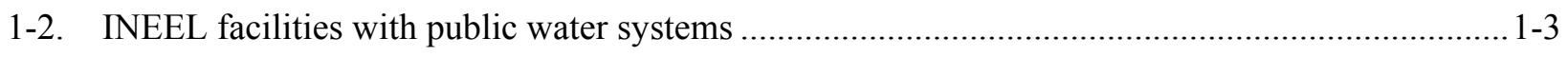

2-1. The Upper Snake River Basin surface water resources.........................................................2-4

2-2. Upper Snake River Basin groundwater resources ............................................................. 2-6

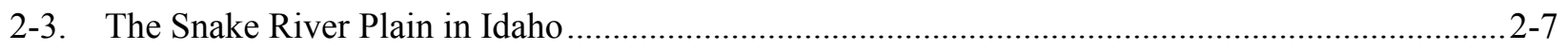

2-4. INEEL-related watersheds ("Pioneer Basins") and public drinking water system facilities.........2-10

2-5. Pioneer Basin surface water resources …....................................................................... 2-11

2-6. The American Falls Watershed …......................................................................................2-12

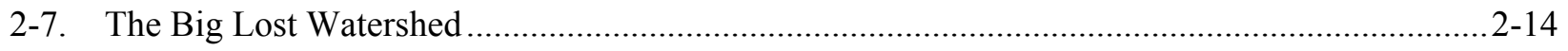

2-8. Big Lost River diversion and spreading areas (adapted from Bennett 1986) .............................2-17

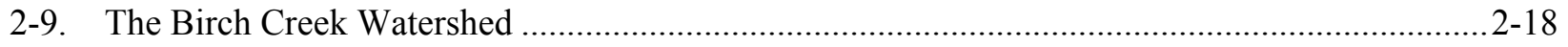

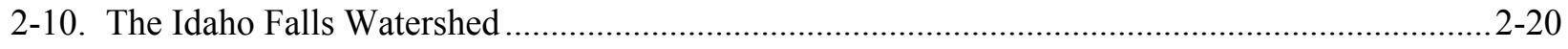

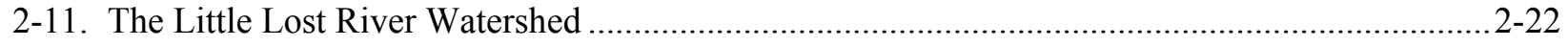

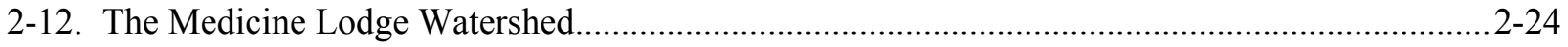




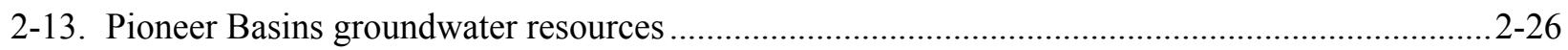

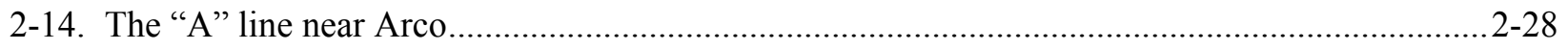

2-15. Elevation of the water table, Snake River Plain Aquifer (1999) ............................................2-30

2-16. INEEL wellhead protection zones ................................................................................ 2-39

2-17. Argonne National Laboratory-West drinking water wellhead protection areas ..........................2-41

2-18. Central Facilities Area drinking water wellhead protection areas .............................................2-43

2-19. Experimental Breeder Reactor-I drinking water wellhead protection areas...............................2-44

2-20. Gun Range drinking water wellhead protection areas ....................................................... 2-45

2-21. Idaho Nuclear Technology and Engineering Center drinking water wellhead

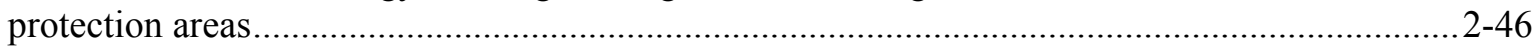

2-22. Main Gate drinking water wellhead protection areas ........................................................... 2-48

2-23. Naval Reactors Facility drinking water wellhead protection areas ..........................................2-49

2-24. Power Burst Facility drinking water wellhead protection areas ..............................................2-50

2-25. Radioactive Waste Management Complex drinking water wellhead protection areas..................2-51

2-26. Test Area North/Containment Test Facility and Test Area North/Technical Support Facility drinking water wellhead protection areas ..................................................... 2-53

2-27. Test Reactor Area drinking water well protection areas .......................................................2-54

2-28. INEEL surface water/groundwater conjunctive areas ............................................................2-55

2-29. Development and land use near the Idaho National Engineering and Environmental Laboratory

2-30. Distribution of chloride in water from the Snake River Plain Aquifer in the south-central part of the INEEL, 1988 (Bartholomay 1998)...

2-31. Distribution of nitrate in water from the Snake River Plain Aquifer in the south-central part of the INEEL, 1998 (Bartholomay 1998).....

2-32. Distribution of specific conductance in water from the Snake River Plain Aquifer in the south-central part of the INEEL, 1998 (Bartholomay 1998)................................2-80

2-33. Distribution of tritium in water from the Snake River Plain Aquifer in the south-central part of the INEEL, 1998 (Bartholomay 1998)

2-34. Distribution of strontium-90 in water from the Snake River Plain Aquifer in the south-central part of the INEEL, 1998 (Bartholomay 1998)... 
2-35. Distribution of soil and groundwater contaminants relative to wellhead protection areas at the INEEL

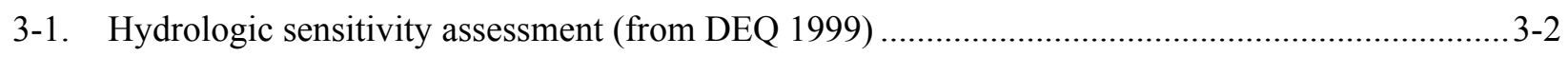

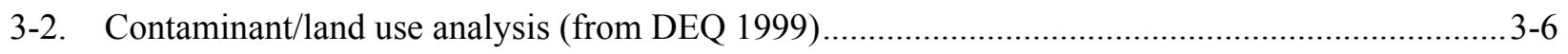

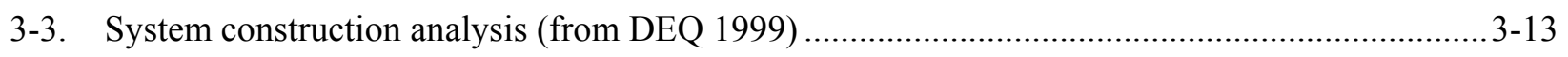

4-1. Susceptibility Rating Sheet............................................................................................. $4-2$

TABLES

1-1. Facilities at the INEEL with public water systems.............................................................. $1-8$

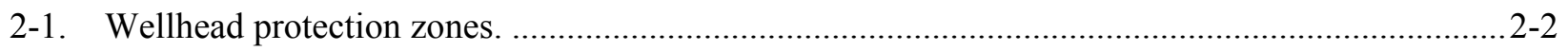

2-2. Calculated-fixed method radii for wells in eastern Snake River Plain basalt (DEQ 1999)............2-2

2-3. Watersheds in the Upper Snake River Basin, Idaho, Utah, Wyoming. .....................................2-5

2-4. Watersheds and aquifers directly associated with the INEEL ..................................................

2-5. EPA-listed streams in the Big Lost River Watershed (17040218)..........................................2-15

2-6. EPA-listed streams in the Little Lost River Watershed (17040217)......................................2-21

2-7. EPA-listed streams in the Medicine Lodge Watershed (17040215). .......................................2-23

2-8. RESSQC program variables at each INEEL public water system facility...............................2-34

2-9. Summary of INEEL wellhead protection area delineation specifications.................................2-38

2-10. Summary of potential sources of groundwater contamination (DEQ 1997)............................2-57

2-11. Clean Water Aact 303(d) listed streams tributary to the INEEL............................................2-60

2-12. Argonne National Laboratory-West constituents of concern for source water protection ............2-65

2-13. Central Facilities Area constituents of interest for source water protection................................2-66

2-14. Idaho Nuclear Technology and Engineering Center constituents of interest for

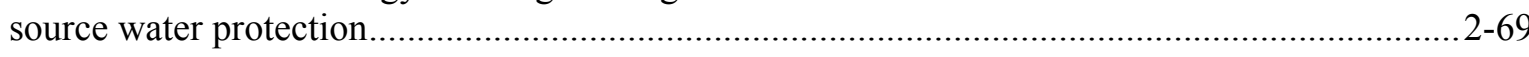

2-15. Naval Reactors Facility constituents of interest for source water protection ............................2-71

2-16. Power Burst Facility constituents of interest for source water protection ..................................2-72

2-17. Radioactive Waste Management Complex constituents of interest for source water protection. 
2-18. Test Area North constituents of interest for source water protection

2-19. Test Reactor Area constituents of interest for source water protection.

3-1. Hydrologic sensitivity analysis of INEEL public water systems

3-2. State of Idaho contaminant categories (from DEQ 1999).

3-3. State of Idaho contaminant leachability classes (from DEQ 1999).

3-4. INEEL groundwater potential contaminant sources/land use analysis....................................... $3-9$

3-5. INEEL drinking water well construction evaluation....................................................... $3-11$

3-6. Five-year summary of drinking water parameters of interest at the INEEL. ............................ 3-14

4-1. Overall susceptibility ratings of public water systems at the INEEL........................................ $4-3$ 


\section{ACRONYMS}

\begin{tabular}{|c|c|}
\hline ANP & Aircraft Nuclear Propulsion \\
\hline ANL-W & Argonne National Laboratory-West \\
\hline ATR & Advanced Test Reactor \\
\hline BBWI & Bechtel BWXT Idaho, LLC \\
\hline CERCLA & Comprehensive Environmental Response, Compensation, and Liability Act \\
\hline CFA & Central Facilities Area \\
\hline CTF & Containment Test Facility \\
\hline CWA & Clean Water Act \\
\hline D\&D & decommissioned and decontaminated \\
\hline DEQ & Idaho Department of Environmental Quality \\
\hline DOE-ID & DOE Idaho Operations Office \\
\hline EBR-I & Experimental Breeder Reactor No. 1 \\
\hline EBR-II & Experimental Breeder Reactor No. 2 \\
\hline ECF & Expended Core Facility \\
\hline EPA & U.S. Environmental Protection Agency \\
\hline ETR & Engineering Test Reactor \\
\hline FCF & Fuel Cycle Facility \\
\hline FMF & Fuel Manufacturing Facility \\
\hline GIS & geographic information system \\
\hline gpm & gallons per minute \\
\hline HFEF & Hot Fuel Examination Facility \\
\hline IDAPA & Idaho Administrative Procedures Act \\
\hline IET & Initial Engine Test Facility \\
\hline INEEL & Idaho National Engineering and Environmental Laboratory \\
\hline INEL & Idaho National Engineering Laboratory \\
\hline INTEC & Idaho Nuclear Technology and Engineering Center \\
\hline IOC & inorganic compounds \\
\hline IWD & Industrial Waste Ditch \\
\hline $\mathrm{L} \& \mathrm{O}$ & Laboratory and Office building \\
\hline MCL & maximum contaminant level \\
\hline MTR & Materials Test Reactor \\
\hline NPDES & National Pollutant Discharge Elimination System \\
\hline NODA & Naval Ordnance Disposal Area \\
\hline NRF & Naval Reactors Facility \\
\hline NRTS & National Reactor Testing Station \\
\hline PBF & Power Burst Facility \\
\hline PDWS & Public Drinking Water System \\
\hline
\end{tabular}




\begin{tabular}{|c|c|}
\hline $\begin{array}{l}\text { PEW } \\
\text { PL } \\
\text { PREPP } \\
\text { PWS }\end{array}$ & $\begin{array}{l}\text { Process Equipment Waste } \\
\text { Public Law } \\
\text { Process Experimental Pilot Plant } \\
\text { public water system }\end{array}$ \\
\hline $\begin{array}{l}\text { RCRA } \\
\text { RWMC }\end{array}$ & $\begin{array}{l}\text { Resources Conservation and Recovery Act } \\
\text { Radioactive Waste Management Complex }\end{array}$ \\
\hline $\begin{array}{l}\text { SDA } \\
\text { SDWA } \\
\text { SL } \\
\text { SMC } \\
\text { SOC } \\
\text { SPERT }\end{array}$ & $\begin{array}{l}\text { Subsurface Disposal Area } \\
\text { Safe Drinking Water Act } \\
\text { sewage lagoons } \\
\text { Special Manufacturing Capability } \\
\text { synthetic organic compound } \\
\text { Special Power Excursion Reactor }\end{array}$ \\
\hline $\begin{array}{l}\text { TAN } \\
\text { TAN/CTF } \\
\text { TAN/TSF } \\
\text { TCE } \\
\text { TRA } \\
\text { TREAT } \\
\text { TRU } \\
\text { TSA } \\
\text { TSF }\end{array}$ & $\begin{array}{l}\text { Test Area North } \\
\text { Test Area North/Contained Test Facility } \\
\text { Test Area North/Technical Support Facility } \\
\text { trichloroethylene } \\
\text { Test Reactor Area } \\
\text { Transient Reactor Test Facility } \\
\text { transuranic } \\
\text { Transuranic Storage Area } \\
\text { Technical Support Facility }\end{array}$ \\
\hline $\begin{array}{l}\text { USGS } \\
\text { USRB }\end{array}$ & $\begin{array}{l}\text { United States Geological Survey } \\
\text { Upper Snake River Basin }\end{array}$ \\
\hline VOC & volatile organic compound \\
\hline $\begin{array}{l}\text { WEC } \\
\text { WRRTF } \\
\text { WHPA }\end{array}$ & $\begin{array}{l}\text { Westinghouse Electric Company } \\
\text { Water Reactor Research Test Facility } \\
\text { Well Head Protection Area }\end{array}$ \\
\hline $\mathrm{PF}$ & Zero Power Physics Reactor \\
\hline
\end{tabular}




\section{INEEL Source Water Assessment Program 1. INTRODUCTION}

The 1996, Congress amended the Safe Drinking Water Act (P.L.104-182) extensively, in part to establish a "Source Water Assessment Program." This program requires all public water systems to:

- $\quad$ Delineate those areas that supply water to their systems

- Evaluate all significant potential sources of contamination within those areas

- $\quad$ Evaluate the system's susceptibility to becoming contaminated by those sources [Sections 1453 and 1428(b)].

Each of the major operational facilities and some smaller miscellaneous facilities at the Idaho National Engineering and Environmental Laboratory (INEEL) have their own public water systems. The source of water for each of the INEEL drinking water systems is groundwater pumped from the eastern Snake River Plain Aquifer. Since the INEEL operates public water systems, it is required to conduct a source water assessment and develop a source water assessment and management program.

The INEEL is a government-owned reservation, in southeastern Idaho, approximately 25 miles west of Idaho Falls, Idaho (Figure 1-1). The INEEL covers approximately $890 \mathrm{mi}^{2}$, extending a maximum 39 miles from north to south and 36 miles from east to west. There are nine major operational areas at the INEEL, in addition to miscellaneous facilities (Figure 1-2). Additional support and administrative facilities are located in Idaho Falls.

The federal government established the INEEL in 1949 as the National Reactor Testing Station for the construction and testing of various kinds of nuclear reactors, primarily to demonstrate reactor safety. Of the 52 reactors built at the INEEL, only two are still active. Nonreactor research activities included testing of irradiated fuels, the recovery of uranium from spent fuels, reactor training, and storage of low-level and transuranic (TRU) wastes. In 1975, the INEEL was also designated as one of the nation's five National Environmental Research Parks for the scientific study of the environment and land management (Fritzen 1991). The INEEL's current mission is centered on the development, demonstration, and deployment of advanced science and engineering technology and information to the private sector. The emphasis of this mission is to improve United States competitiveness and security, the efficient production and use of energy, and the quality of life and the environment worldwide.

\subsection{Regulatory Background}

To protect the nation's drinking water resources, Congress amended the Safe Drinking Water Act (SDWA) extensively (Pubic Law 99-339, 100 Stat. 666, 1986), including the establishment of a national "Wellhead Protection Program." The purpose of the wellhead protection program was to protect the public water system's groundwater supplies from contamination. This program required each state to develop a statewide groundwater protection program. In 1989, the Idaho legislature enacted the Groundwater Quality Protection Act, which called for the formation of a Groundwater Quality Council, which subsequently developed the State's Groundwater Quality Plan. The State's Groundwater Quality Plan established the basis for the State of Idaho's Wellhead Protection Plan (DEQ 1997). However, while the 1986 SDWA amendments made it mandatory that each state develop a statewide wellhead protection 


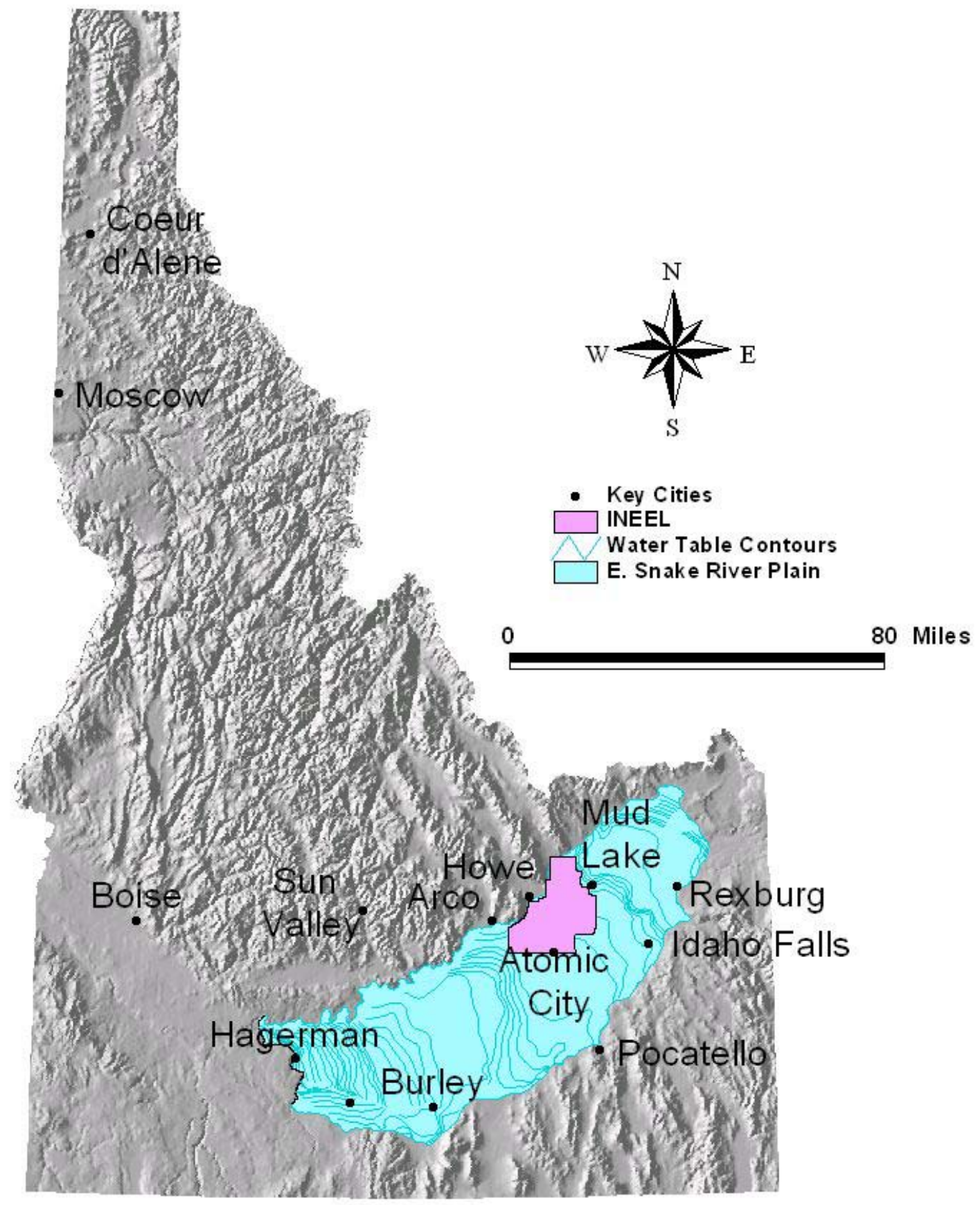

Figure 1-1. Location of the Idaho National Engineering and Environmental Laboratory. 


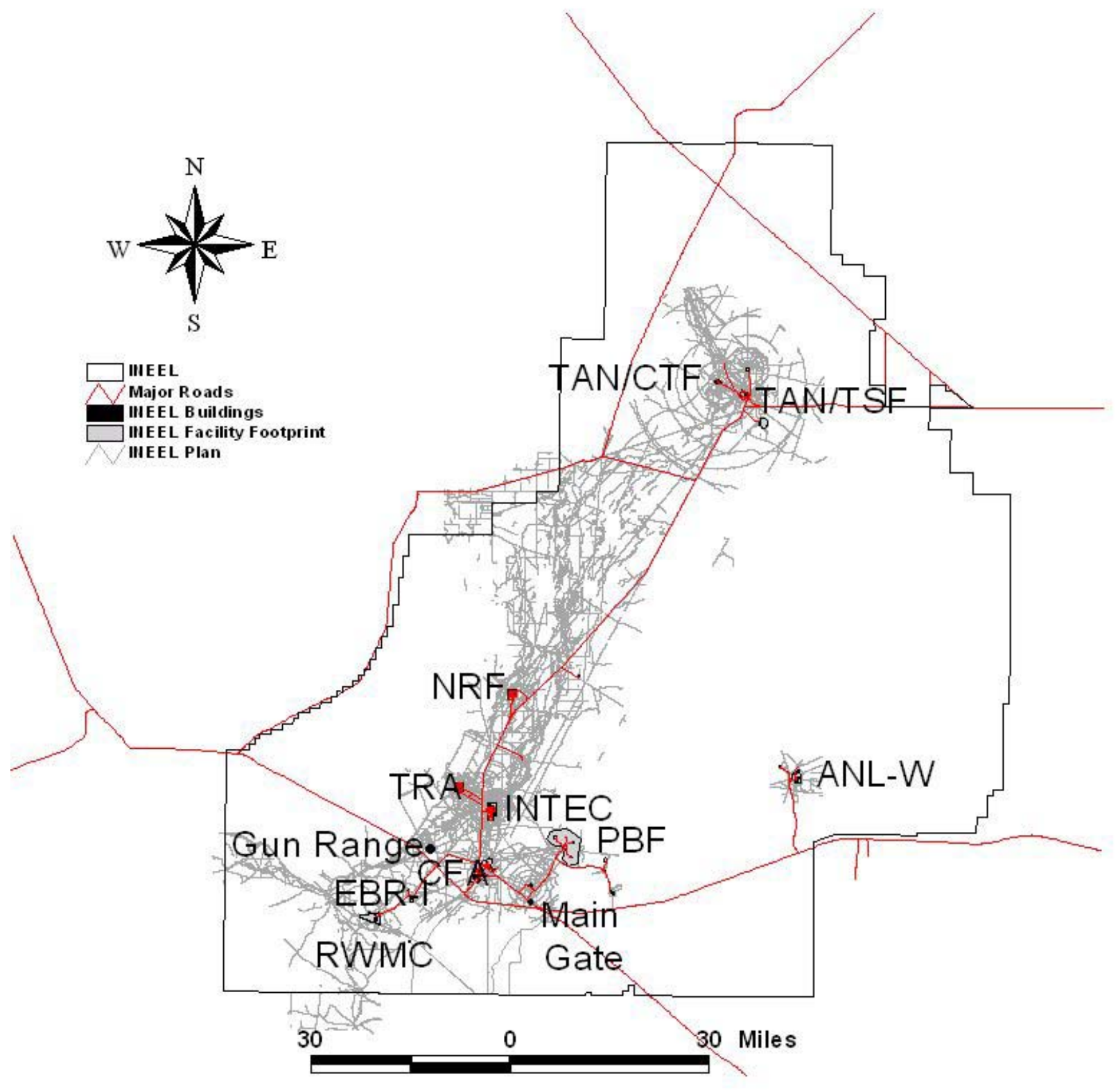

Figure 1-2. INEEL facilities with public water systems. 
program, the State of Idaho's Wellhead Protection Plan did not mandate the development and implementation of local or regional wellhead programs. The Wellhead Protection Plan established a framework for public water systems that chose to develop a wellhead program, but it made the development and implementation of those programs voluntary.

In 1996, Congress again extensively amended the Safe Drinking Water Act (P.L.104-182), in part to establish a "Source Water Assessment Program." This amendment included specific requirements for state source water assessment programs (Sections 1453 and 1428(b)) and for source water petition programs (Section 1454). This program is mandatory for all public water systems. It requires each public water system to:

- $\quad$ Delineate the boundaries of all sources of water that supply water to their system

- Identify all significant potential sources of contamination within those boundaries

- $\quad$ Evaluate its susceptibility to becoming contaminated by those sources.

The State of Idaho has federal "Primacy" over all Safe Drinking Water Act regulations within the state including federal facilities such as the INEEL. According to those responsibilities, the Idaho Department of Environmental Quality (DEQ) wrote the 1999 Idaho Source Water Assessment Plan (DEQ 1999). The Idaho Source Water Assessment Plan establishes a statewide program that meets the requirements of the SDWA Amendments of 1996 (P.L. 104-182) for state source water assessment programs (Sections 1453 and 1428(b)) and for source water petition programs (Section 1454). This plan establishes a framework for developing and implementing source water assessment programs for all public water systems in Idaho.

In 1993, the INEEL committed to develop a comprehensive Wellhead Protection Program for the INEEL (DOE/ID-10274). The appropriate information collected and the activities undertaken under that Wellhead Protection Program is one of the primary sources for this Source Water Assessment Program.

\subsection{INEEL Source Water Policy}

It is the INEEL's policy to provide safe, high quality drinking water to all personnel and visitors. At a minimum, all drinking water at the INEEL meets the requirements of the SDWA. To the extent practical, the INEEL's goal is to protect all sources of drinking water from contamination. Water treatment options are only used when source water protection efforts are insufficient to meet SDWA standards. The INEEL will implement its goal through proactive approaches including:

- Contaminant source inventory and control

- $\quad$ Properly locating and constructing drinking water wells

- Use of appropriate physical barriers

- Administrative procedures and requirements.

The INEEL will actively monitor its drinking water sources and will, as necessary, establish proactive management plans and emergency contingency plans to protect the safety and health of both INEEL personnel and visitors. 


\subsection{Purpose and Scope}

The purpose of this INEEL Source Water Assessment Plan is to evaluate the potential of unacceptable levels of water-related contaminants being introduced into any of the INEEL's public water systems. In Fiscal Year 2003, this Source Water Assessment Plan will be followed by the development of an INEEL Source Water Management Plan. Together, these two plans will provide the necessary information and outline the framework and requirements for the INEEL to meet the intent and criteria of the SDWA Sources Water Assessment and Management Programs and to protect the INEEL's public water systems from unacceptable types/concentrations of contaminants.

Under Idaho's Source Water Assessment Program, the Idaho Department of Environmental Quality (DEQ) has committed to conduct all source water assessments within the state unless a given public water system volunteers to participate in the assessment or conduct their own assessment. In 1994, the INEEL committed to develop its own comprehensive wellhead protection program and has since committed to the state to develop its own source water assessment and protection plans. Since the City of Idaho Falls supplies drinking water at the INEEL's Idaho Falls facilities, the City's Source Water Assessment and Management Plans will address those facilities.

In 1994, the INEEL decided to initiate a wellhead protection program via its Ground Water Protection Management Program (see DOE/ID-10274 1994). Although the program was voluntary, INEEL began delineating and evaluating wellhead protection areas in accordance with the state's draft Idaho Wellhead Protection Plan in 1996. The reason for doing so at that time was that the program's framework provided a very practical and logical process for the INEEL to evaluate and protect its drinking water sources. During this period, groundwater flow and contaminant assessments were completed. Even though the INEEL did not complete a formal wellhead protection plan at that time, much of this earlier work was used as the basis for removing sources of contamination from wellhead protection areas. In addition, it was used for siting facilities and screening activities to evaluate what sources of contamination might negatively impact the INEEL's water supplies. Much of this earlier wellhead protection work is incorporated into this Source Water Assessment Plan.

One of the major differences between the state's earlier wellhead protection program and this Source Water Assessment Program is that this later program requires an evaluation of all sources of water that supply water and can potentially contaminate a public water system. The INEEL's evaluation entailed a quick preliminary evaluation of all the watersheds and aquifers surrounding the INEEL that may hydrologically influence the INEEL or be hydrologically influenced by the INEEL. Initially, this evaluation began with the Upper Snake River Basin. The evaluation was then able to focus on only those watersheds and aquifers that can directly impact the INEEL's public water systems to determine qualitatively whether they pose a risk to the INEEL's public water systems.

In addition to meeting the INEEL's Safe Drinking Water System Source Water Assessment needs, these evaluations will help the INEEL:

- $\quad$ Better manage its water resources in an integrated water resource manner

- $\quad$ Meet DOE's obligations under the "Unified Federal Policy for Ensuring a Watershed Approach to Federal Land and Resource Management" (EPA 2000)

- $\quad$ Respond in case of a water-based emergency or threat situation. 
To be considered "complete" by the Environmental Protection Agency, each source water assessment program plan must:

- Delineate the source water protection area for each public water system

- Inventory all significant potential sources of contamination within that source water protection area

- $\quad$ Determine the public water system's susceptibility to contamination by sources inventoried within each source water area

- $\quad$ Notify the public about the source water assessment.

To meet these criteria, the INEEL's Source Water Assessment Program Plan:

- Documents the location of INEEL production and potable water wells

- Delineates the boundaries of the area that provides water to the public water system (i.e., the Source Water Program Area). This task includes determining watershed(s) and aquifer(s) contributing water directly to the system

- $\quad$ Delineates wellhead protection areas

- Inventories all significant potential sources of contaminants in the wellhead protection areas that may impact the public water system. This includes all point and non-point sources that may contribute a significant source of contaminants or pollutants, in quantities that may have a significant impact on the supply

- $\quad$ Evaluates the susceptibility of each public water system to contamination

- $\quad$ Develops wellhead protection policies and procedures.

\subsection{Overview of INEEL Facilities with Public Water Systems}

There are nine major operational areas and numerous smaller facilities or areas (e.g., small guard shacks, storage buildings, administrative support buildings, and various other buildings) throughout the INEEL (Figure 1-2). Each major facility has its own source(s) of drinking water and/or production water. The smaller facilities may or may not have their own on-site source of water, depending on its purpose, use, and status (e.g., active or inactive). In all cases, the on-site source of drinking at the INEEL is groundwater pumped from the eastern Snake River Plain Aquifer.

A public water system is defined as a system that serves 25 or more people on a regular basis or has 15 or more service connections. According to the Idaho Regulations for Public Water Systems (Idaho Administrative Procedures Act [IDAPA] 58.01.08), drinking water systems are classified as either:

- “Community" systems (e.g., cities and subdivisions)

- "Nontransient noncommunity" systems (e.g., schools and factories that have their own well) - more stringent requirements than transient, noncommunity water systems. Includes the remaining INEEL public water systems. 
- "Transient noncommunity" systems (e.g., campgrounds and restaurants that have their own well) - includes the Experimental Breeder Reactor (EBR)-I, the Gun Range, and the Main Gate

Historically, the INEEL has withdrawn water from 32 different water wells. Presently, the INEEL monitors 12 public water systems at 12 INEEL facilities/areas that withdraw water from a total of 21 wells (Table 1-1). These withdrawals are allowed under a single, site-wide federal Reserved Water Right. In 1990, The U.S. Department of Energy Idaho Operations Office (DOE-ID) negotiated an agreement with the State of Idaho quantifying that water right. At the completion of the Snake River Basin Adjudication, this right will include all groundwater pumped at the INEEL (Water Rights Agreement between the State of Idaho and the United States, for the United States Department of Energy, 1990). It establishes a maximum pumping rate of $80 \mathrm{ft}^{3} / \mathrm{s}$ to a maximum volume of $35,000 \mathrm{acre}-\mathrm{ft} / \mathrm{year}$ $\left(1.14 \times 10^{10} \mathrm{gal} / \mathrm{year}\right)$, and a maximum consumptive use volume of $35,000 \mathrm{acre}-\mathrm{ft} / \mathrm{year}$ $\left(1.14 \times 10^{10} \mathrm{gal} /\right.$ year $)$.

The following sections describe the location and provide a brief overview of each INEEL facility that has a public water system.

\subsubsection{Argonne National Laboratory-West}

Argonne National Laboratory-West (ANL-W) is located in the southeastern portion of the INEEL. ANL-W is operated by the University of Chicago under the guidance of the U.S. Department of Energy Chicago Operations Office, and is supported by a local area office (DOE-CH-AAO). ANL-W has administrative control over approximately 890 acres, while the facilities themselves cover less than 60 acres.

Construction began at the present ANL-W site in the mid-1950s and became operational in stages from 1959 through the mid-1960s. The ANL-W was constructed to research and develop liquid metal fast breeder reactor technology.

The ANL-W consists of seven major research complexes:

- $\quad$ Experimental Breeder Reactor No. 2 (EBR-II)

- $\quad$ Transient Reactor Test Facility (TREAT)

- $\quad$ Zero Power Physics Reactor (ZPPR)

- $\quad$ Fuel Manufacturing Facility (FMF)

- $\quad$ Hot Fuel Examination Facility (HFEF)

- $\quad$ Fuel Cycle Facility (FCF)

- $\quad$ Laboratory and Office building (L\&O).

The ANL-W public water system (PWS\# 6060036) serves approximately 675 people. The system consists of two wells and their associated infrastructure as shown in Table 1-1. Water pumped from these wells is disinfected with a mixed oxidant system and then enters the ANL-W distribution system downstream of booster pumps located in building ANLW-754. 
Table 1-1. Facilities at the INEEL with public water systems.

\begin{tabular}{|c|c|c|c|c|c|c|c|c|}
\hline Facility Name & $\begin{array}{c}\text { PWS } \\
\text { Number }\end{array}$ & System Type & Wells & Location & $\begin{array}{c}\text { Yr } \\
\text { Completed }\end{array}$ & $\begin{array}{c}\text { Depth } \\
(\mathrm{ft})\end{array}$ & Use & $\begin{array}{c}\text { Pump Type, } \\
\text { Horsepower, } \\
\text { Pumping Capacity }\end{array}$ \\
\hline \multirow[t]{2}{*}{$\begin{array}{l}\text { Argonne National } \\
\text { Laboratory- West } \\
\text { (ANL-W) }\end{array}$} & \multirow[t]{2}{*}{6060036} & \multirow[t]{2}{*}{$\begin{array}{l}\text { Nontransient, } \\
\text { noncommunity }\end{array}$} & EBR-II \#1 & $\begin{array}{l}\text { ANL-W } \\
754\end{array}$ & 1958 & 747 & $\begin{array}{l}\text { Production and } \\
\text { potable water }\end{array}$ & $\begin{array}{l}\text { Turbine } \\
200 \text { horsepower } \\
900 \text { gpm at } 700 \mathrm{TDH}\end{array}$ \\
\hline & & & EBR-II \#2 & $\begin{array}{l}\text { ANL-W } \\
756\end{array}$ & 1959 & 753 & $\begin{array}{l}\text { Production and } \\
\text { potable water }\end{array}$ & $\begin{array}{l}\text { Turbine } \\
200 \text { horsepower, } \\
900 \text { gpm at } 700 \mathrm{TDH}\end{array}$ \\
\hline \multirow[t]{2}{*}{$\begin{array}{l}\text { Central Facilities } \\
\text { Area (CFA) }\end{array}$} & \multirow[t]{2}{*}{6120008} & \multirow[t]{2}{*}{$\begin{array}{l}\text { Nontransient, } \\
\text { noncommunity }\end{array}$} & CFA \#1 & CFA 651 & 1942. & 685 & $\begin{array}{l}\text { Production and } \\
\text { potable water }\end{array}$ & $\begin{array}{l}\text { Submersible } \\
150 \text { horsepower } \\
650 \text { gpm }\end{array}$ \\
\hline & & & CFA \#2 & CFA 642 & 1944 & 681 & $\begin{array}{l}\text { Production and } \\
\text { potable water }\end{array}$ & $\begin{array}{l}\text { Submersible } \\
125 \text { horsepower } \\
600 \mathrm{gpm}\end{array}$ \\
\hline $\begin{array}{l}\text { Experimental } \\
\text { Breeder Reactor-I } \\
\text { (EBR-I) }\end{array}$ & 6120009 & $\begin{array}{l}\text { Transient, } \\
\text { noncommunity }\end{array}$ & EBR-I & EBR 711 & 1949 & 1,075 & & $\begin{array}{l}\text { Submersible, } \\
200 \text { horsepower } \\
800 \text { gpm }\end{array}$ \\
\hline Gun Range & 6120025 & $\begin{array}{l}\text { Transient, } \\
\text { noncommunity }\end{array}$ & $\begin{array}{l}\text { Gun Range } \\
\text { Well (Rifle } \\
\text { Range Well) }\end{array}$ & B21-607 & 1990 & 626 & Potable water & $\begin{array}{l}\text { Submersible } \\
20 \text { horsepower } \\
200 \text { gpm }\end{array}$ \\
\hline \multirow{2}{*}{$\begin{array}{l}\text { Idaho Nuclear } \\
\text { Technology and } \\
\text { Engineering } \\
\text { Center (INTEC) }\end{array}$} & \multirow[t]{2}{*}{6120012} & \multirow[t]{2}{*}{$\begin{array}{l}\text { Nontransient, } \\
\text { noncommunity }\end{array}$} & $\begin{array}{l}\text { CPP \#4 } \\
(\mathrm{CPP}-04)\end{array}$ & $\begin{array}{l}\text { Near CPP } \\
1767\end{array}$ & 1983 & 700 & Potable water & $\begin{array}{l}\text { Submersible } \\
100 \text { horsepower } \\
400 \text { gpm }\end{array}$ \\
\hline & & & $\begin{array}{l}\text { CPP \#5 } \\
(\mathrm{CPP}-05)\end{array}$ & $\begin{array}{l}\text { Near CPP } \\
1767\end{array}$ & 1991 & 725 & & $\begin{array}{l}\text { Submersible } \\
100 \text { horsepower } \\
400 \text { gpm }\end{array}$ \\
\hline Main Gate & 6120015 & $\begin{array}{l}\text { Transient, } \\
\text { noncommunity }\end{array}$ & $\begin{array}{l}\text { Main Gate } \\
\text { Well } \\
\text { (Badging } \\
\text { Facility Well) }\end{array}$ & B27-605 & 1985 & 644 & Potable water & $\begin{array}{l}\text { Submersible } \\
5 \text { horsepower } \\
20 \text { gpm }\end{array}$ \\
\hline
\end{tabular}


Table 1-1. (continued).

\begin{tabular}{|c|c|c|c|c|c|c|c|c|}
\hline Facility Name & $\begin{array}{c}\text { PWS } \\
\text { Number }\end{array}$ & System Type & Wells & Location & $\begin{array}{c}\mathrm{Yr} \\
\text { Completed } \\
\end{array}$ & $\begin{array}{l}\text { Depth } \\
\text { (ft) }\end{array}$ & Use & $\begin{array}{c}\text { Pump Type, } \\
\text { Horsepower, } \\
\text { Pumping Capacity }\end{array}$ \\
\hline \multirow[t]{2}{*}{$\begin{array}{l}\text { Naval Reactors } \\
\text { Facility (NRF) }\end{array}$} & \multirow[t]{2}{*}{6120016} & \multirow[t]{2}{*}{$\begin{array}{l}\text { Nontransient, } \\
\text { noncommunity }\end{array}$} & NRF-2 & NRF-612 & 1951 & 528 & Potable water & $\begin{array}{l}\text { Vertically oriented, } \\
\text { centrifugal, multi-stage } \\
350 \text { horsepower } \\
2,000 \mathrm{gpm}\end{array}$ \\
\hline & & & NRF-3 & NRF-622 & 1956 & 546 & Potable water & $\begin{array}{l}\text { Vertically oriented, } \\
\text { centrifugal, multi-stage } \\
300 \text { horsepower } \\
2,000 \mathrm{gpm}\end{array}$ \\
\hline \multirow[t]{2}{*}{$\begin{array}{l}\text { Power Burst } \\
\text { Facility (PBF) }\end{array}$} & \multirow[t]{2}{*}{6120019} & \multirow[t]{2}{*}{$\begin{array}{l}\text { Nontransient, } \\
\text { noncommunity }\end{array}$} & $\begin{array}{l}\text { PBF \#1 } \\
\text { (SPERT-1) }\end{array}$ & $\begin{array}{l}\text { PER } 601 \\
602\end{array}$ & 1955 & 653 & $\begin{array}{l}\text { Production and } \\
\text { potable water }\end{array}$ & $\begin{array}{l}\text { Submersible } \\
80 \text { horsepower } \\
400 \text { gpm }\end{array}$ \\
\hline & & & $\begin{array}{l}\text { PBF \#2 } \\
\text { (SPERT-2) }\end{array}$ & PER 614 & 1960 & 1,217 & $\begin{array}{l}\text { Production and } \\
\text { potable water }\end{array}$ & $\begin{array}{l}\text { Turbine } \\
200 \text { horsepower } \\
800 \text { gpm }\end{array}$ \\
\hline $\begin{array}{l}\text { Radioactive } \\
\text { Waste } \\
\text { Management } \\
\text { Complex } \\
\text { (RWMC) }\end{array}$ & 6120018 & $\begin{array}{l}\text { Nontransient, } \\
\text { noncommunity }\end{array}$ & $\begin{array}{l}\text { RWMC } \\
\text { Production } \\
\text { Well }\end{array}$ & WMF 603 & 1974 & 685 & $\begin{array}{l}\text { Production and } \\
\text { potable water }\end{array}$ & $\begin{array}{l}\text { Line shaft } \\
75 \text { horsepower } \\
240 \mathrm{gpm}\end{array}$ \\
\hline \multirow{2}{*}{$\begin{array}{l}\text { Test Area } \\
\text { North/Contained } \\
\text { Test Facility } \\
\text { (TAN/CTF) }\end{array}$} & \multirow[t]{2}{*}{6120013} & \multirow[t]{2}{*}{$\begin{array}{l}\text { Nontransient, } \\
\text { noncommunity }\end{array}$} & $\begin{array}{l}\text { CTF \#1 } \\
\text { (FET-1) }\end{array}$ & TAN 632 & 1957 & 339 & $\begin{array}{l}\text { Production and } \\
\text { potable water }\end{array}$ & $\begin{array}{l}\text { Line shaft } \\
100 \text { horsepower } \\
1,000 \mathrm{gpm}\end{array}$ \\
\hline & & & $\begin{array}{l}\text { CTF \#2 } \\
(\text { FET-2) }\end{array}$ & TAN 639 & 1968 & 462 & $\begin{array}{l}\text { Production and } \\
\text { potable water }\end{array}$ & $\begin{array}{l}\text { Turbine } \\
100 \text { horsepower } \\
1,000 \text { gpm }\end{array}$ \\
\hline
\end{tabular}


Table 1-1. (continued).

\begin{tabular}{|c|c|c|c|c|c|c|c|c|}
\hline Facility Name & $\begin{array}{c}\text { PWS } \\
\text { Number }\end{array}$ & System Type & Wells & Location & $\begin{array}{c}\text { Yr } \\
\text { Completed } \\
\end{array}$ & $\begin{array}{c}\text { Depth } \\
(\mathrm{ft})\end{array}$ & Use & $\begin{array}{c}\text { Pump Type, } \\
\text { Horsepower, } \\
\text { Pumping Capacity }\end{array}$ \\
\hline \multirow{2}{*}{$\begin{array}{l}\text { Test Area } \\
\text { North/Technical } \\
\text { Support Facility } \\
\text { (TAN/TSF) }\end{array}$} & \multirow[t]{2}{*}{6120021} & \multirow[t]{2}{*}{$\begin{array}{l}\text { Nontransient, } \\
\text { noncommunity }\end{array}$} & $\begin{array}{l}\text { TSF \#1 } \\
\text { (ANP-01) }\end{array}$ & TAN 612 & 1953 & 365 & $\begin{array}{l}\text { Production and } \\
\text { potable water }\end{array}$ & $\begin{array}{l}\text { Line shaft } \\
80 \text { horsepower } \\
1,000 \mathrm{gpm}\end{array}$ \\
\hline & & & $\begin{array}{l}\text { TSF \#2 } \\
\text { (ANP-02) }\end{array}$ & TAN 613 & 1953 & 346 & $\begin{array}{l}\text { Production and } \\
\text { potable water }\end{array}$ & $\begin{array}{l}\text { Line shaft } \\
80 \text { horsepower } \\
1,000 \mathrm{gpm}\end{array}$ \\
\hline \multirow[t]{3}{*}{$\begin{array}{l}\text { Test Reactor Area } \\
\text { (TRA) }\end{array}$} & \multirow[t]{3}{*}{6120020} & \multirow[t]{3}{*}{$\begin{array}{l}\text { Nontransient, } \\
\text { noncommunity }\end{array}$} & TRA \#1 & TRA 601 & 1950 & 600 & $\begin{array}{l}\text { Production and } \\
\text { potable water }\end{array}$ & $\begin{array}{l}\text { Line shaft } \\
700 \text { horsepower } \\
3,200 \mathrm{gpm}\end{array}$ \\
\hline & & & TRA \#3 & TRA 650 & 1957 & 602 & $\begin{array}{l}\text { Production and } \\
\text { potable water }\end{array}$ & $\begin{array}{l}\text { Line shaft } \\
600 \text { horsepower } \\
3,800 \text { gpm }\end{array}$ \\
\hline & & & TRA \#4 & TRA 672 & 1963 & 975 & $\begin{array}{l}\text { Production and } \\
\text { potable water }\end{array}$ & $\begin{array}{l}\text { Line shaft } \\
350 \text { horsepower } \\
2,000 \text { gpm }\end{array}$ \\
\hline
\end{tabular}




\subsubsection{Central Facilities Area}

Central Facilities Area (CFA) is located in the south-central part of the INEEL and is operated by Bechtel BWXT Idaho, LLC (BBWI) through the DOE Idaho Operations Office (DOE-ID). The original facilities were built in the 1940s and 1950s to house Naval Gunnery Range personnel and were later used for office space for National Reactor Testing Station (NRTS) personnel. The facilities have been modified over the years and now provide four major types of functional space: craft, office, services, and laboratory space.

The CFA public water system (PWS \# 6120008) serves approximately 800 employees. The system consists of two wells, a disinfection system, and their associated infrastructure shown in Table 1-1. Water pumped from these wells enters the CFA distribution system at CFA-1603.

\subsubsection{Experimental Breeder Reactor-I}

Experimental Breeder Reactor-I (EBR-I) consists of the Reactor Building and Annex (EBR-601), situated on approximately 10 acres approximately 6 miles southwest of CFA and is operated by BBWI for DOE-ID. EBR was constructed in 1949 and the early 1950s. Criticality was first achieved in 1951, and several reactor cores were tested. EBR-I was decontaminated and decommissioned in 1963 and has been designated as a national historic site. EBR-I is now operated as a museum on a seasonal basis.

The EBR-I public water system (PWS \#6120009) serves a larger number of visitors from Memorial Day to Labor Day. The system consists of one well and its associated infrastructure shown in Table 1-1. Water pumped from this well enters the EBR-I distribution system at EBR-601.

\subsubsection{Gun Range}

The Gun Range (also known as the Rifle Range or the Weapons Complex) was constructed in 1950 as a firing range for INEEL security forces to practice firing weapons. It is 3 miles west of the CFA, off Portland Avenue. It is operated by BBWI for DOE-ID. The Gun Range has a deep-water well for water supply, telephone lines, a septic tank and seepage pit, an underground electrical supply, and the practice range.

The Gun Range public water system (PWS\# 6120025) serves approximately 12 people. This system consists of one well and its associated infrastructure shown in Table 1-1. Water from this well enters the Gun Range distribution system at Building B-21-608.

\subsubsection{Idaho Nuclear Technology and Engineering Center}

The Idaho Nuclear Technology and Engineering Center (INTEC) covers approximately 200 acres in the south-central part of the INEEL and is operated by BBWI for DOE-ID. INTEC was constructed in the late 1940s to reprocess spent nuclear fuel from naval and research reactors. INTEC includes laboratories and processing facilities, process chemical storage facilities, process chemical and waste transfer pipelines, process waste storage and disposal facilities, office and maintenance facilities, and nonprocess waste disposal facilities. The principal facilities at INTEC are listed below:

- $\quad$ Fuel storage facilities

- $\quad$ Fuel reprocessing facilities

- $\quad$ Process Equipment Waste (PEW) facility 
- $\quad$ Tank farm

- Waste calcining facilities.

The INTEC public water system (PWS\# 6120012) serves approximately 850 people. This system consists of two wells, a disinfection system, and their associated infrastructure as shown in Table 1-1. Water pumped from these wells enters the INTEC distribution system at CPP-614.

\subsubsection{Main Gate Well}

The Main Gate (also know as the Badging Facility) is the main entrance on the south end of the INEEL, approximately 5 miles south of CFA. It is operated by BBWI for DOE-ID. Approximately 12 personnel use this drinking water daily. Visitors badging into the INEEL are also potential water users at this facility. Water pumped from this well enters the Main Gate distribution system at Building B-27-605.

The Main Gate Facility public water system (PWS\# 6120015) serves about 12 people. This system consists of one well and its associated infrastructure as shown in Table 1-1.

\subsubsection{Naval Reactors Facility}

The Naval Reactors Facility (NRF) covers 84 acres on the west-central part of the INEEL. Established in 1949, NRF is operated for the U.S. Naval Nuclear Propulsion Program by Bechtel Bettis, Inc., Bettis Atomic Power Laboratory-Idaho. The principal facilities at NRF are three former naval reactor prototypes (S1W, A1W, and S5G) and the Expended Core Facility (ECF). The S1W, A1W, and S5G prototypes were shut down in October 1989, January 1994, and May 1995, respectively.

Developmental nuclear fuel material samples, naval spent fuel, and irradiated reactor plant components/materials are examined at ECF. The knowledge gained from these examinations is used to improve current designs and to monitor the performance of existing reactors. The naval spent fuel examined at ECF is critical to the design of longer-lived cores, which results in the creation of less spent fuel requiring disposition. NRF is also preparing naval fuel for dry storage and eventual transportation to a repository.

The NRF public water system (PWS\# 6120016) serves 792 people. This system consists of two wells and their associated infrastructure shown in Table 1-1. Water pumped from these wells enters the NRF distribution system at Building NRF-620 Boilerhouse.

\subsubsection{Power Burst Facility}

The Power Burst Facility (PBF) is located in the south-central portion of the INEEL. It is operated by BBWI for DOE-ID. It was initially constructed to test reactor transient behavior and for safety studies on light-water-moderated enriched fuel systems. Following conclusion of the Special Power Excursion Reactor (SPERT) studies, PBF and its support facilities were placed on standby in 1975. All four reactors were removed, and in 1984 and 1985 the facilities were radiologically decontaminated and decommissioned (D\&D'd). The PBF operational area consists of five subareas:

- $\quad$ PBF Control Area

- $\quad$ PBF/SPERT I Area 
- Waste Engineering Development Facility (WEDF/SPERT II)

- Waste Experimental Reduction Facility (WERF/SPERT III)

- $\quad$ Mixed Waste Storage Facility (MWSF/SPERT IV).

The Power Burst Facility public water system (PWS\# 6120019) serves approximate 80 people. This system consists of two wells, a mixed oxidant disinfection system, and their associated infrastructure shown in Table 1-1. The water from these wells enters the PBF distribution system in PER-638, which then distributes the water to all facilities in the PBF area.

\subsubsection{Radioactive Waste Management Complex}

The Radioactive Waste Management Complex (RWMC) covers 144 acres 7 miles southwest of CFA. It is operated by BBWI for DOE-ID. Construction began at RWMC in 1952. It was constructed to store and dispose of solid TRU-contaminated and low-level radioactive wastes from the INEEL and other DOE facilities. It also supports research and development projects dedicated to shallow land burial technology, and alternate ways of removing, reprocessing, and repackaging TRU wastes. The RWMC is subdivided into three primary areas:

- $\quad$ Administrative Area

- $\quad$ Subsurface Disposal Area (SDA)

- $\quad$ Transuranic Storage Area (TSA).

The RWMC public water system (PWS\# 6120018) supplies all of the drinking water for over 300 people. This system consists of one well, a disinfection system, and its associated infrastructure shown in Table 1-1. Water from this well enters the RWMC distribution system at WMF-604.

\subsubsection{Test Area North}

Test Area North (TAN) is approximately 27 miles northeast of CFA. TAN consists of several facilities that research and develop reactor performance. These facilities include:

- $\quad$ Containment Test Facility (CTF)

- $\quad$ Initial Engine Test Facility (IET)

- $\quad$ Technical Support Facility (TSF)

- Water Reactor Research Test Facility (WRRTF).

Only CTF and TSF have active public water systems. 
1.4.10.1 Test Area North/Containment Test Facility. The original mission of TAN/CTF was to perform reactor loss-of-coolant studies. After these studies were completed, the facility was decontaminated and used to decontaminate and decommission reactors used in the Aircraft Nuclear Propulsion (ANP) Program. Presently, TAN/CTF is dedicated to the Special Manufacturing Capability (SMC) Project.

The TAN/CTF public water system (PWS\# 6120013) serves approximately 250 people. The system consists of two wells, a disinfection system, and their associated infrastructure shown in Table 1-1. Water pumped from these wells enters the TAN/CTF distribution system at TAN-614.

1.4.10.2 Test Area North/Technical Support Facility. TAN/TSF is located in the central part of TAN and serves as the main administration, assembly, and maintenance section for TAN. Major programs at TSF include the Three-Mile Island Unit 2 Core Off-Site Examination, Process Experimental Pilot Plant (PREPP), Spent Fuel Program, and the Specific Manufacturing Capability (SMC).

The TAN/TSF public water system (PWS\# 6120021) serves approximately 90 people. The system consists of two wells, a disinfection system, and their associated infrastructure shown in Table 1-1. Water from these wells enters the TAN/TSF distribution system at TAN-610.

\subsubsection{Test Reactor Area}

The Test Reactor Area (TRA) is in the south central portion of the INEEL, approximately 5 miles northwest of CFA. It is operated by BBWI for DOE-ID. The area was originally established in the early 1950 s to conduct experiments associated with the development, testing, and analysis of materials used in nuclear and reactor applications. Major facilities at TRA include:

- $\quad$ Advanced Test Reactor (ATR) - Approximately half of TRA personnel support the ATR

- $\quad$ Materials Test Reactor (MTR) - Presently inactive

- $\quad$ Engineering Test Reactor (ETR) — Presently inactive.

The TRA public water system (PWS\# 6120020) serves approximately 430 people. This system consists of three wells, a mixed oxidant disinfection system, and their associated infrastructure shown in Table 1-1. Water from these wells enters the TRA distribution system at TRA-608.

\subsection{Source $\mathrm{H}_{2} \mathrm{O}$ Tool}

To help facilitate a better understanding of the hydrology, potential contaminant sources and the potential susceptibility of the INEEL Public Water Systems evaluated in this Source Water Assessment, the INEEL has developed a user friendly, interactive tool for viewing and evaluating the geographic information system (GIS) data used to develop the figures and to conduct the analyses in this plan. The Source $\mathrm{H}_{2} \mathrm{O}$ Tool, provided in Appendix E, is a self extracting, Windows-driven system that can view and manipulate the GIS files utilized in this assessment. It can be run from most standard PCs without using additional GIS software and without significant knowledge of GIS operating systems. The Source $\mathrm{H}_{2} \mathrm{O}$ Tool can be extracted and operated based solely on the information provided in the Source $\mathrm{H}_{2} \mathrm{O}$ User's Guide (Appendix E). 


\section{ASSESSMENT RESULTS}

\subsection{Source Water Delineations}

Source water delineations establish the physical area around a public water system that may contribute water and contaminants to the surface water or well intake. Since contaminant sources within this area may be captured by the system, it is the area of focus for the source water assessment and for later monitoring and management efforts (e.g., eliminating potential sources of contaminants). Source water delineations may include watershed delineations, groundwater delineations, or a combination of surface water and groundwater delineations (conjunctive delineations).

When conducting a source water delineation, the Idaho Department of Environmental Quality (DEQ) has a five-part approach:

1. Initial surface water delineation

2. More focused surface water delineation

3. 24-hour emergency response delineation

4. Wellhead delineation method for systems supplied solely by groundwater supplies

5. Conjunctive source delineation.

Initial surface water delineations must include the entire topographic watershed that may provide surface water to the public water system.

Then a more focused surface water delineation may be conducted in large watersheds to focus the delineation/contaminant source inventory on those areas most likely to contribute contaminants to the given surface water source. This surface water source may be a stream, lake, or wetland. However, for the INEEL's assessment, all potential sources of surface water are streams or man-made disposal ponds. The criteria for a stream buffer delineation includes a minimum 500-foot-wide buffer zone parallel to the given stream bank or shoreline, including tributaries. This zone must extend upstream from the intake a minimum of 25 miles upstream or to the 4-hour stream flow time-of-travel boundary, whichever is greater, calculated equal to the estimated stream velocity of a 10 -year flood event.

The third surface water delineation is a 24-hour emergency response delineation that allows the operator enough time to prepare and respond to contaminants spilled directly into a stream that supplies a given public water system. This delineation requires a 500-foot-wide buffer zone parallel to the given stream bank or shoreline, including tributaries extending upstream from the intake to the 24-hour stream flow time-of-travel boundary.

The fourth delineation method is the wellhead delineation method for systems that are supplied solely by groundwater supplies. The Idaho Wellhead Protection Plan (DEQ 1997) establishes a framework for delineating wellhead protection areas. The plan requires identifying four distinct zones for each well. These zones, presented in order of the stringency with which they should be managed, are provided in Table 2-1. The Idaho Wellhead Protection Plan identifies five techniques for the delineation of wellhead protection areas; three of these techniques ("Arbitrary Fixed Radius Method" for "Transient, Non-Community" systems and "Calculated Fixed Radius Method" or "Refined Analytical Method" for any type of system) can be applied at the INEEL. The Arbitrary Fixed Radius Method and Calculated Fixed Radius Method are conservative techniques, which establish four large, concentric, fixed-radius 
circles around each wellhead as boundaries for the four protection areas, zones. The Arbitrary-Fixed Radius Method consists of drawing a predetermined fixed radius around a given well on an appropriate base map. This method is typically used for transient systems where there is less information available or risk associated with the supply. The Calculated-Fixed Radius Method uses radii determined from standard tables developed for established pumping rate in specified aquifers (Table 2-2).

Table 2-1. Wellhead protection zones.

\begin{tabular}{lll}
\hline \multicolumn{1}{c}{ Zone } & \multicolumn{1}{c}{ Criteria } & \multicolumn{1}{c}{ Comments } \\
\hline Zone IA & $\begin{array}{l}\text { 50-foot sanitary setback radius } \\
\text { from the well } \\
\text { Z-year time of travel for } \\
\text { contaminants in the aquifer } \\
\text { 6-year time of travel for } \\
\text { contaminants in the aquifer } \\
\text { Zone II }\end{array}$ & $\begin{array}{l}\text { State law presently requires this } \\
\text { sanitary setback }\end{array}$ \\
Zone III & $\begin{array}{l}\text { contaminants in the aquifer } \\
\text { Consider both vertical and } \\
\text { horizontal recharge }\end{array}$ & $\begin{array}{l}\text { Was considered for both river } \\
\text { recharge and for vadose effects } \\
\text { related to impeding/enhancing } \\
\text { flow and spreading of water } \\
\text { during vertical migration through } \\
\text { the vadose }\end{array}$ \\
\hline
\end{tabular}

Table 2-2. Calculated-fixed method radii for wells in eastern Snake River Plain basalt (DEQ 1999).

\begin{tabular}{lcccccccccc}
\hline & \multicolumn{10}{c}{ Peak Pumping Rate } \\
\cline { 2 - 11 } Zone & $\begin{array}{c}50 \\
\mathrm{gpm}\end{array}$ & $\begin{array}{c}100 \\
\mathrm{gpm}\end{array}$ & $\begin{array}{c}500 \\
\mathrm{gpm}\end{array}$ & $\begin{array}{c}1,000 \\
\mathrm{gpm}\end{array}$ & $\begin{array}{c}2,000 \\
\mathrm{gpm}\end{array}$ & $\begin{array}{c}3,000 \\
\mathrm{gpm}\end{array}$ & $\begin{array}{c}4,000 \\
\mathrm{gpm}\end{array}$ & $\begin{array}{c}5,000 \\
\mathrm{gpm}\end{array}$ & $\begin{array}{c}6,000 \\
\mathrm{gpm}\end{array}$ & $\begin{array}{c}7,000 \\
\mathrm{gpm}\end{array}$ \\
\hline IB & $2,700 \mathrm{ft}$ & $2,700 \mathrm{ft}$ & $3,000 \mathrm{ft}$ & $3,300 \mathrm{ft}$ & $3,700 \mathrm{ft}$ & $4,200 \mathrm{ft}$ & $4,600 \mathrm{ft}$ & $5,000 \mathrm{ft}$ & $5,300 \mathrm{ft}$ & $5,700 \mathrm{ft}$ \\
$\mathrm{II}$ & $5,300 \mathrm{ft}$ & $5,300 \mathrm{ft}$ & $5,600 \mathrm{ft}$ & $5,900 \mathrm{ft}$ & $6,400 \mathrm{ft}$ & $6,900 \mathrm{ft}$ & $7,700 \mathrm{ft}$ & $7,800 \mathrm{ft}$ & $8,200 \mathrm{ft}$ & $8,600 \mathrm{ft}$ \\
III & $8,800 \mathrm{ft}$ & $8,800 \mathrm{ft}$ & $9,100 \mathrm{ft}$ & $9,500 \mathrm{ft}$ & $10,100 \mathrm{ft}$ & $10,600 \mathrm{ft}$ & $11,100 \mathrm{ft}$ & $11,600 \mathrm{ft}$ & $12,000 \mathrm{ft}$ & $12,500 \mathrm{ft}$ \\
\hline
\end{tabular}

The Refined Method estimates a capture zone boundary for a wellhead using various modeling codes and requires access to data such as transmissivity, hydraulic gradient, flow angle, and pump rate. This method allows the water purveyor to use site-specific knowledge of the aquifer properties to establish the protection area zones and boundaries. Given sufficient information, the Refined Method provides a better estimate of the actual catchment area for a wellhead, as well as a smaller protection area that must be managed.

The final category is the Conjunctive Source Delineation. This category addresses public water systems that utilize groundwater supplies near a local source of surface water that is directly and immediately hydraulically interconnected to the system's groundwater supply. Theoretically, all groundwater supplies are hydraulically interconnected to surface water supplies and water, depending on the location and local/regional conditions, and may flow from a given stream to a given aquifer or vice-a-versa. However, the purpose of this delineation is to determine if the aquifer is under a "direct hydraulic connection" or if it is under a "direct influence" of the surface water source. Systems under a "direct influence" of the surface water source are those where there is a significant risk that pathogens in the surface water source can quickly/easily migrate into the public water system. 
Based on DEQ's guidance (DEQ 1999), each public water system must determine if its supply is from a "conjunctive" source, that is, a hydrologic system where there is significant hydraulic interaction between local surface water and groundwater sources. If there is significant surface water/groundwater interaction, the purveyor is required to determine if the aquifer is under a "direct hydraulic connection" or if it is under a "direct influence" of the surface water source. A direct hydraulic connection is where there is significant stream discharge to the aquifer; however, there is an insignificant risk of protozoan microorganisms being transported to the well because of the natural filtration provided by soil and rock. In this case, the source water assessment for water wells is limited to the groundwater delineation area (i.e., the wellhead protection area). Groundwater under the direct influence of surface water is where there is significant stream discharge to the aquifer; however, there is a significant risk of protozoan microorganisms being transported to the well. In this case, the source water assessment for water wells must also include an evaluation of the entire watershed that provides water to that source of surface water.

\subsubsection{Regional Overview}

The INEEL is in the north-central portion of the Upper Snake River Basin (USRB) (Figure 2-1). The Upper Snake River Basin includes 29,900 $\mathrm{mi}^{2}$ primarily in southeastern Idaho, but it also includes lands in Nevada, Utah and Wyoming. The basin is bounded by and includes Basin and Range faulted mountains that are an extension of the vast Basin and Range region that extends from northern Mexico through much of the western U.S. The Upper Snake River Basin is drained by the Snake River and its tributaries. The Snake River heads in northwestern Wyoming in Yellowstone National Park and flows approximately 80 miles south through northwestern Wyoming, crosses into Idaho at Palisades Reservoir, then turns southwest and flows into the eastern Snake River Plain at Heise, Idaho. From Heise, the Snake River flows about 270 miles through southeastern Idaho, then exits the plain at King Hill (Figure 2-1). While in the Upper Snake River Basin, the Snake River drains 26 watersheds (Table 2-3) either directly via stream flow or indirectly via one of the dozen or so aquifers in the basin (Figure 2-2).

The INEEL is situated on the northeastern edge of the Snake River Plain, which is the most prominent hydrogeological feature of the Upper Snake River Basin. As Figure 2-3 shows, one of the most striking features of the Snake River Plain is that it is one of the few large expanses of land in Idaho that appears to be free of surface water. This is because there is little precipitation on the eastern Snake River Plain, and in general, the soil column is so porous that most surface water infiltrates into the subsurface very rapidly, recharging both local and regional aquifers.

All surface water and groundwater in the Upper Snake River Basin originates from direct precipitation. Precipitation ranges as follows:

- High of about 60 in/year in the Teton Mountains along the eastern margins of the basin

- $\quad$ About 24 in/year in the tributary watersheds north of the INEEL

- About 10 in/year in the lower portions of the plain.

Except for the eastern Snake River Plains "northern tributaries," all precipitation that falls in the basin's tributary watersheds flow via stream flow or groundwater flow directly to the Snake River. Of these northern tributaries, only the Big Wood River flows directly into the Snake River. All water 


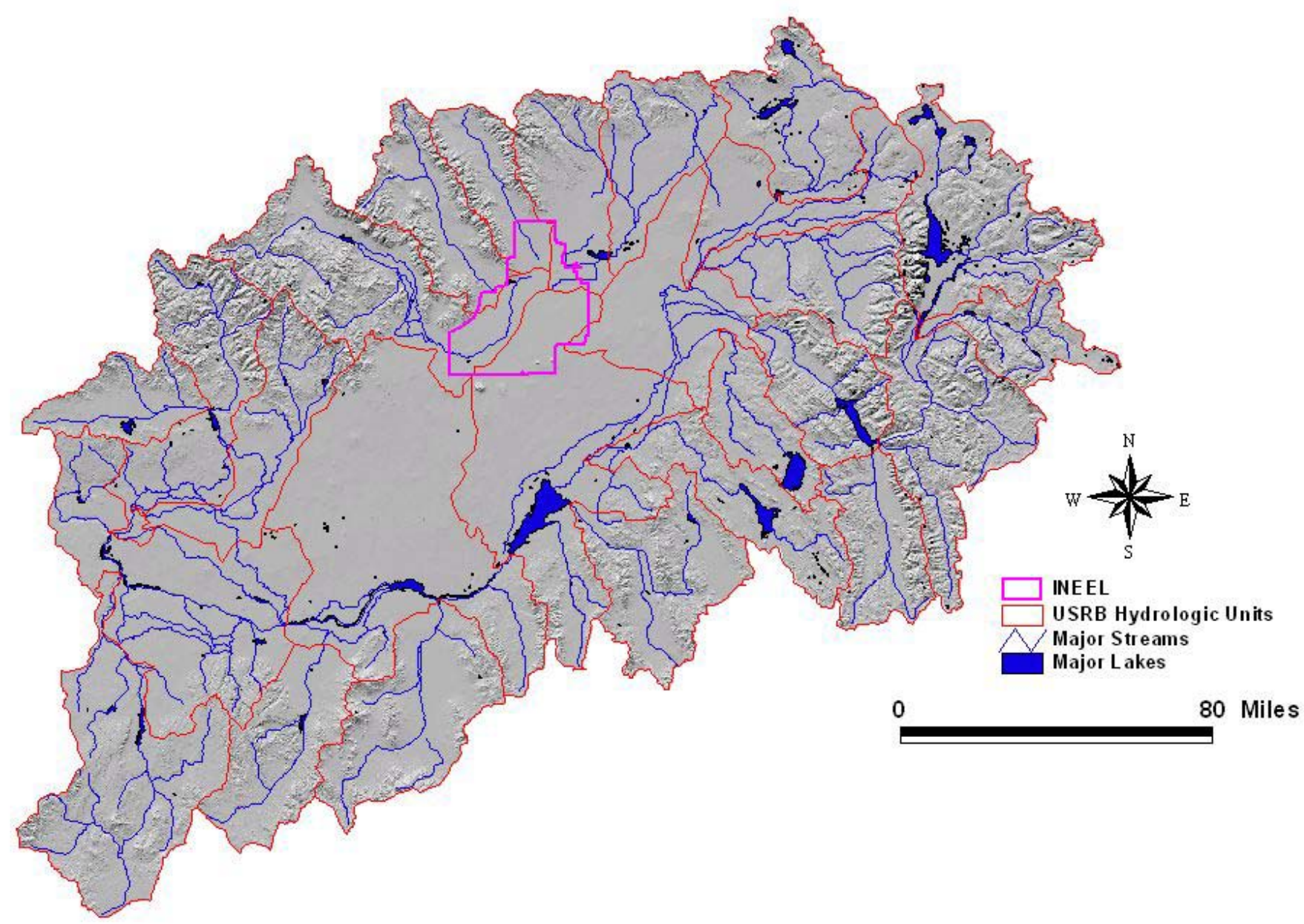

Figure 2-1. The Upper Snake River Basin surface water resources. 
Table 2-3. Watersheds in the Upper Snake River Basin, Idaho, Utah, Wyoming.

\begin{tabular}{|c|c|c|c|c|c|}
\hline Number & Name & $\begin{array}{l}\text { Area } \\
\left(\mathrm{mi}^{2}\right)\end{array}$ & Location & Primary Stream & Tributary \\
\hline 17040101 & Snake Headwaters & 1,680 & Wyoming & Snake River & - \\
\hline 17040102 & Gros Ventre & 638 & Wyoming & Gros Ventre & - \\
\hline 17040103 & Greys-Hobock & 1,570 & Wyoming & Snake River & - \\
\hline 17040104 & Palisades & 915 & Idaho, Wyoming & Snake River & - \\
\hline 17040105 & Salt & 887 & Idaho, Wyoming & & \\
\hline 17040201 & Idaho Falls & 1,140 & Idaho & Snake River & - \\
\hline 17040202 & Upper Henrys & 1,090 & Idaho, Wyoming & $\begin{array}{l}\text { Henrys Fork of the } \\
\text { Snake }\end{array}$ & Eastern \\
\hline 17040203 & Lower Henrys & 1,040 & Idaho, Wyoming & $\begin{array}{l}\text { Henrys Fork of the } \\
\text { Snake }\end{array}$ & Eastern \\
\hline 17040204 & Teton & 1,130 & Idaho, Wyoming & Teton River & Eastern \\
\hline 17040205 & Willow & 645 & Idaho & Willow Creek & Eastern \\
\hline 17040206 & American Falls & 2,850 & Idaho & Snake River & - \\
\hline 17040207 & Blackfoot & 1,080 & Idaho & Blackfoot River & Eastern \\
\hline 17040208 & Portneuf & 1,320 & Idaho & Portneuf River & Eastern \\
\hline 17040209 & Lake Walcott & 3,670 & Idaho & Snake River & - \\
\hline 17040210 & Raft & 1,470 & Idaho & Raft River & Southern \\
\hline 17040211 & Goose & 1,150 & $\begin{array}{l}\text { Idaho, Nevada, } \\
\text { Utah }\end{array}$ & Goose Creek & Southern \\
\hline 17040212 & Upper Snake-Rock & 2,440 & Idaho & Snake River & - \\
\hline 17040213 & Salmon Falls & 2,120 & Idaho, Nevada & Salmon Falls River & Southern \\
\hline 17040214 & Beaver-Camas & 982 & Idaho & Camas Creek & Northern \\
\hline 17040215 & Medicine Lodge & 952 & Idaho & Medicine Lodge Creek & Northern \\
\hline 17040216 & Birch Creek & 692 & Idaho & Birch Creek & Northern \\
\hline 17040217 & Little Lost & 957 & Idaho & Little Lost River & Northern \\
\hline 17040218 & Big Lost & 1,900 & Idaho & Big Lost River & Northern \\
\hline 17040219 & Big Wood & 1,460 & Idaho & Big Wood River & Northern \\
\hline 17040220 & Camas & 672 & Idaho & Camas Creek & Northern \\
\hline 17040221 & Little Wood & 1,120 & Idaho & Little Wood River & Northern \\
\hline
\end{tabular}




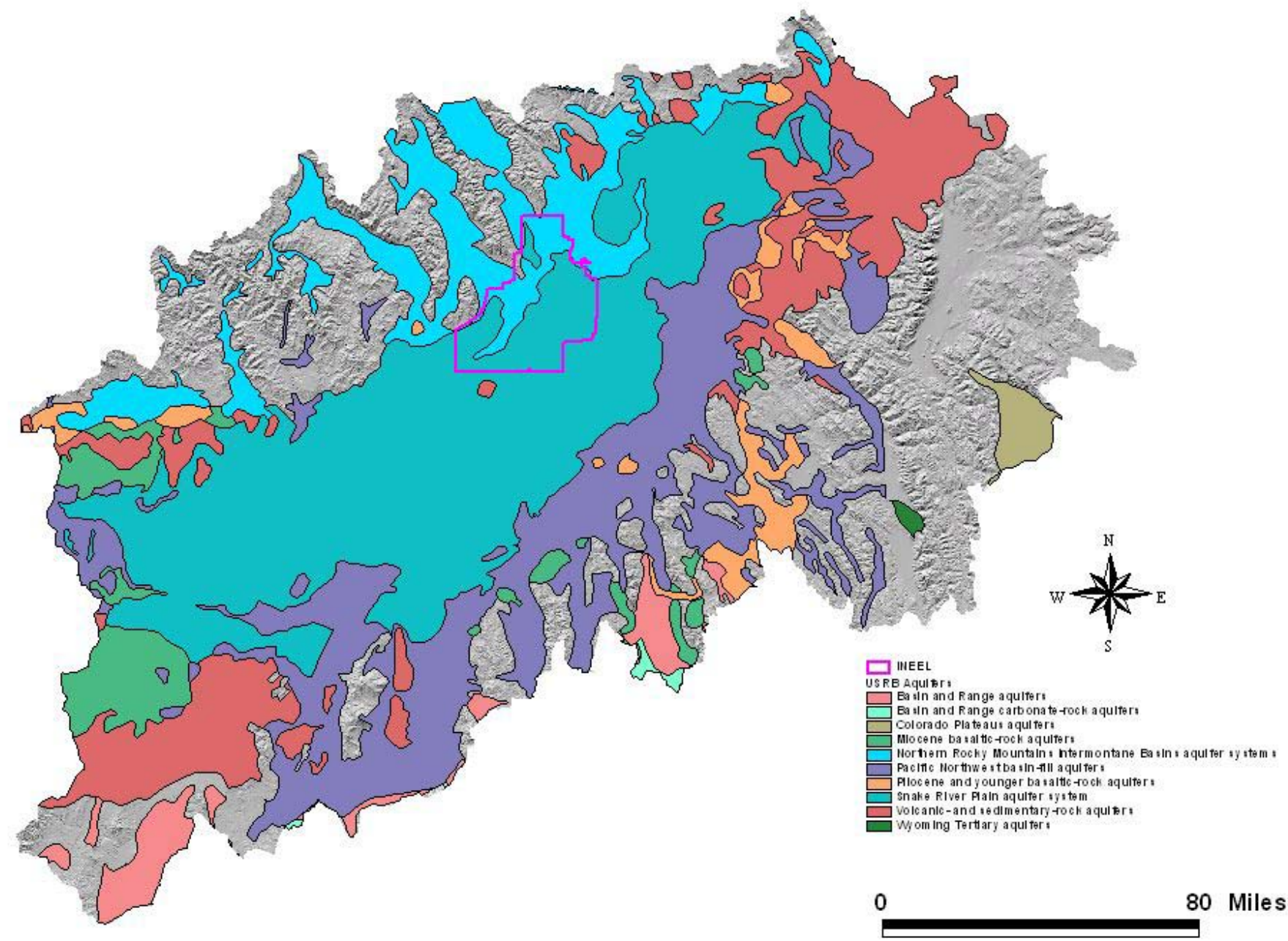

Figure 2-2. Upper Snake River Basin groundwater resources. 


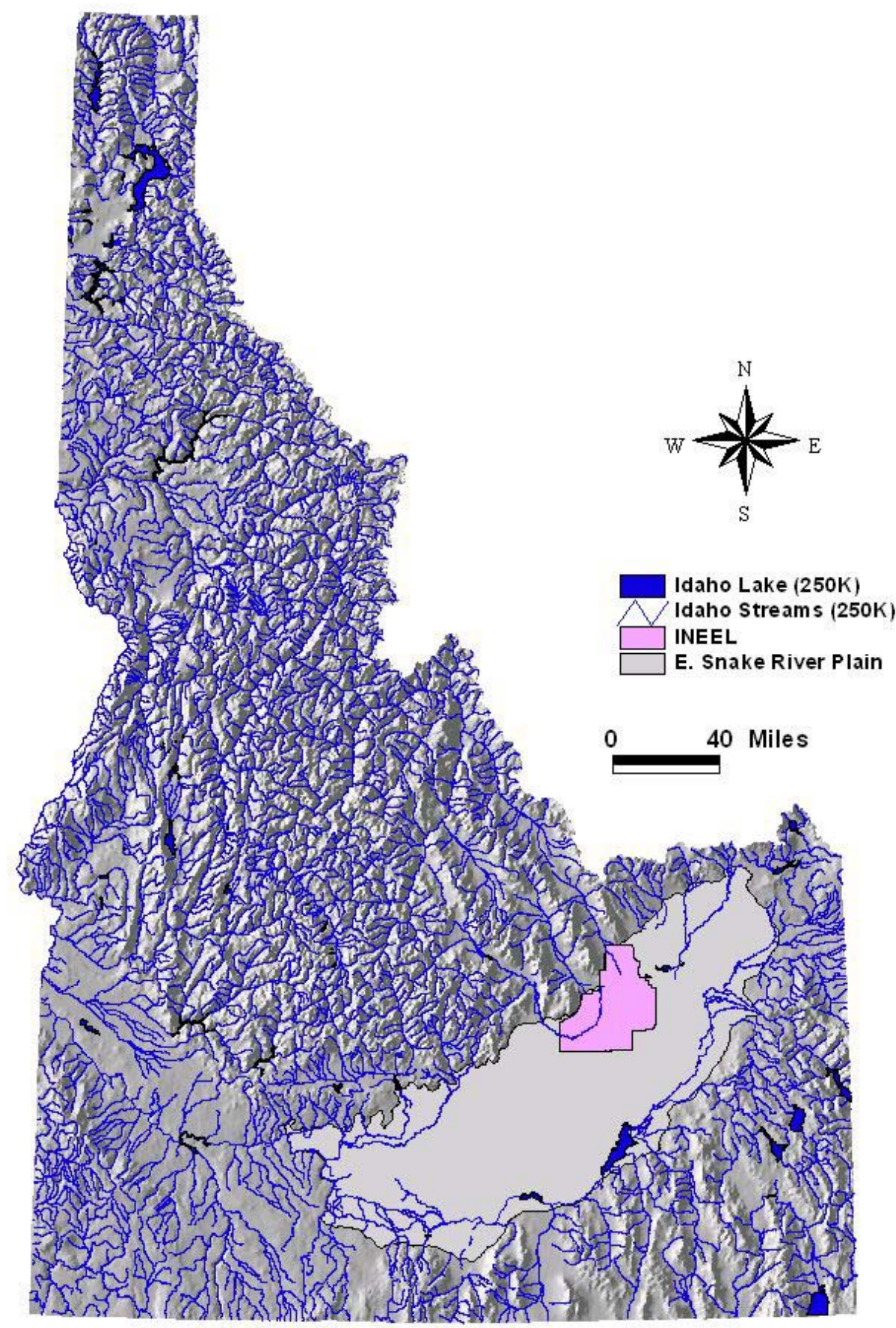

Figure 2-3. The Snake River Plain in Idaho. 
in the Beaver-Camas Creek, Medicine Lodge Creek, Birch Creek, Little Lost River, and the Big Lost River basins eventually "sinks" (seeps) into the eastern Snake River Plain Aquifer or is lost to evapotranspiration. Camas Creek and the Little Wood River both flow into the Big Wood River before it flows into the Snake River. Average stream flow percentages in the eastern Snake River Plain are as follows (Lindholm 1996):

- $\quad 49 \%$ is from the Snake River above Heise

- $\quad 23 \%$ is from the Henry's Fork of the Snake

- $\quad 10 \%$ is from the northern tributaries (Camas-Beaver Creek, Medicine Lodge Creek, Birch Creek, Little Lost River, Big Lost River, Little Wood River, and Big Wood River)

- $\quad$ The remaining $18 \%$ is from the eastern and southern tributaries that join the Snake River downstream of the Henry's Fork.

\subsubsection{Surface Water Delineations}

A "basin" consists of a watershed and the aquifer(s) that underlay it. This section discusses the watershed aspects; the aquifer aspects are discussed in Section 2.1.3.

No public water systems at the INEEL use surface water as their drinking water supply. However, several wells at the INEEL are close to streams where the aquifer is at least under a "direct hydraulic connection" of the streams. Therefore, based on DEQ's guidance (DEQ 1999), the INEEL must delineate all watersheds and aquifers that could potentially impact the groundwater supplies to the INEEL's public water systems. Once delineated, the INEEL must determine whether the stream aquifer systems are a "hydraulically connected" source or "under the direct influence of surface water." If the INEEL's groundwater supply is "under the direct influence of surface water," the surface water sources must be managed along with that portion of the aquifer that could impact the INEEL's public water system (i.e., the wellhead protection areas).

In addition to meeting the state's source water assessment requirements, this process meets, in part, the DOE's goals, as stated in the "Unified Federal Policy for Ensuring a Watershed Approach to Federal Land and Resource Management" (EPA 2000). In addition, by using this approach, the INEEL can evaluate and manage its water resources using an integrated water resources management approach and evaluate its potential risk to water-related natural phenomena (e.g., flooding events) and malevolent acts.

2.1.2.1 Topographic Delineation of INEEL Watersheds. The southern extremities of the Lost River and Lemhi Ranges and the Beaverhead Mountains extend to the western and northwestern borders of the INEEL. At the base of the mountain ranges, the average elevation of the INEEL is about 5,000 $\mathrm{ft}$ above mean sea level. Individual mountains immediately adjacent to the plain rise to elevations of $10,830 \mathrm{ft}$ above mean sea level.

The surface of the eastern Snake River Plain is rolling to broken and is underlain by basalt with a thin, discontinuous covering of surficial sediment. Hundreds of extinct volcanic craters and cones are scattered across the surface of the plain. Craters of the Moon National Monument, Big Southern Butte, Twin Buttes, and many small volcanic cones are aligned generally along a broad volcanic ridge trending northeastward from Craters of the Moon toward the Mud Lake basin (Nace et al. 1972). Between this ridge and the northern edge of the plain is a somewhat lower area from which there is no exterior drainage. The INEEL occupies a substantial part of this closed topographic basin. The topography of the 
INEEL, like that of the entire Snake River Plain, is rolling to broken. The lowest area on the INEEL is the Birch Creek

Using the United States Geological Survey's (USGS') surface water classification scheme, portions of six "watersheds" (USGS Cataloging Units) either drain surface water from the INEEL or recharge surface water to the INEEL. These watersheds include: American Falls (17040206), Big Lost River (17040218), Birch Creek (17040216), Idaho Falls (17040201), Little Lost (17040217), and Medicine Lodge (17040215) (Table 2-4 and Figure 2-4). Combined, these watersheds are sometimes referred to locally as the "Pioneer Basins." The Big Lost River, Birch Creek, Little Lost River, and Medicine Lodge are all part of the northern "closed basins." Each of these streams flow near or onto the INEEL

(Figure 2-5) where they terminate either by being lost to their underlying local aquifer(s), or the regional eastern Snake River Plain Aquifer, or via evapotranspiration. The Lake Walcott basin was evaluated briefly because some maps show it intersecting the INEEL, but other maps do not. This is a result of the relatively flat topography in this area making it difficult to delineate the exact boundary of the watershed. However, only a very minor portion of the watershed potentially intersects the INEEL. In addition, since no INEEL facilities are in that watershed, no streams are in the watershed near the INEEL, and any water flowing in this area would flow away from the INEEL, this watershed was not reviewed any further. The remaining watersheds are discussed below.

2.1.2.1.1 American Falls Watershed (17040206)—The American Falls Basin includes the American Falls Watershed, which straddles the north and south sides of the Snake River along the southeastern portion of the eastern Snake River Plain, and portions of three aquifers: the eastern Snake River Plain, Rockland, and Arbon Valley Aquifers (Figure 2-6). Topographically, it consists of gently rolling hills and large expanses of relatively flat land that slopes from the north or northwest, near Arco and the INEEL, toward the Snake River. The most prominent topographic features north of the Snake River are the East, Middle, and Big Southern Buttes. This area is an integral part of the eastern Snake River Plain; therefore, the geology of this area is discussed further as part of the eastern Snake River Plain Aquifer discussion (Section 2.1.3.3).

Table 2-4. Watersheds and aquifers directly associated with the INEEL.

\begin{tabular}{cccl}
\hline${\text { Aquifer } \#^{\mathrm{a}}}$ & \multicolumn{1}{c}{ Aquifer Name $^{\mathrm{a}}$} & \multicolumn{1}{c}{${\text { Watershed } \#^{\mathrm{b}}}$ Watershed Name $^{\mathrm{b}}$} \\
\hline 39 & Snake River Plain & 17040201 & Idaho Falls \\
& & 17040206 & American Falls \\
& & 17040209 & Lake Walcott \\
& & 17040215 & Medicine Lodge \\
& 17040216 & Birch Creek \\
& & 17040217 & Little Lost \\
62 & Birch Creek Valley & 17040218 & Big Lost \\
64 & Little Lost River Valley & 17040216 & Birch Creek \\
66 & Big Lost River Valley & 17040217 & Little Lost \\
67 & Copper Basin & 17040218 & Big Lost \\
\hline a. Aquifer names and numbers from Graham and Campbell 1981. & Big Lost \\
b. Watershed names and numbers after Seber et al. 1987. & 17040218 & \\
\hline
\end{tabular}




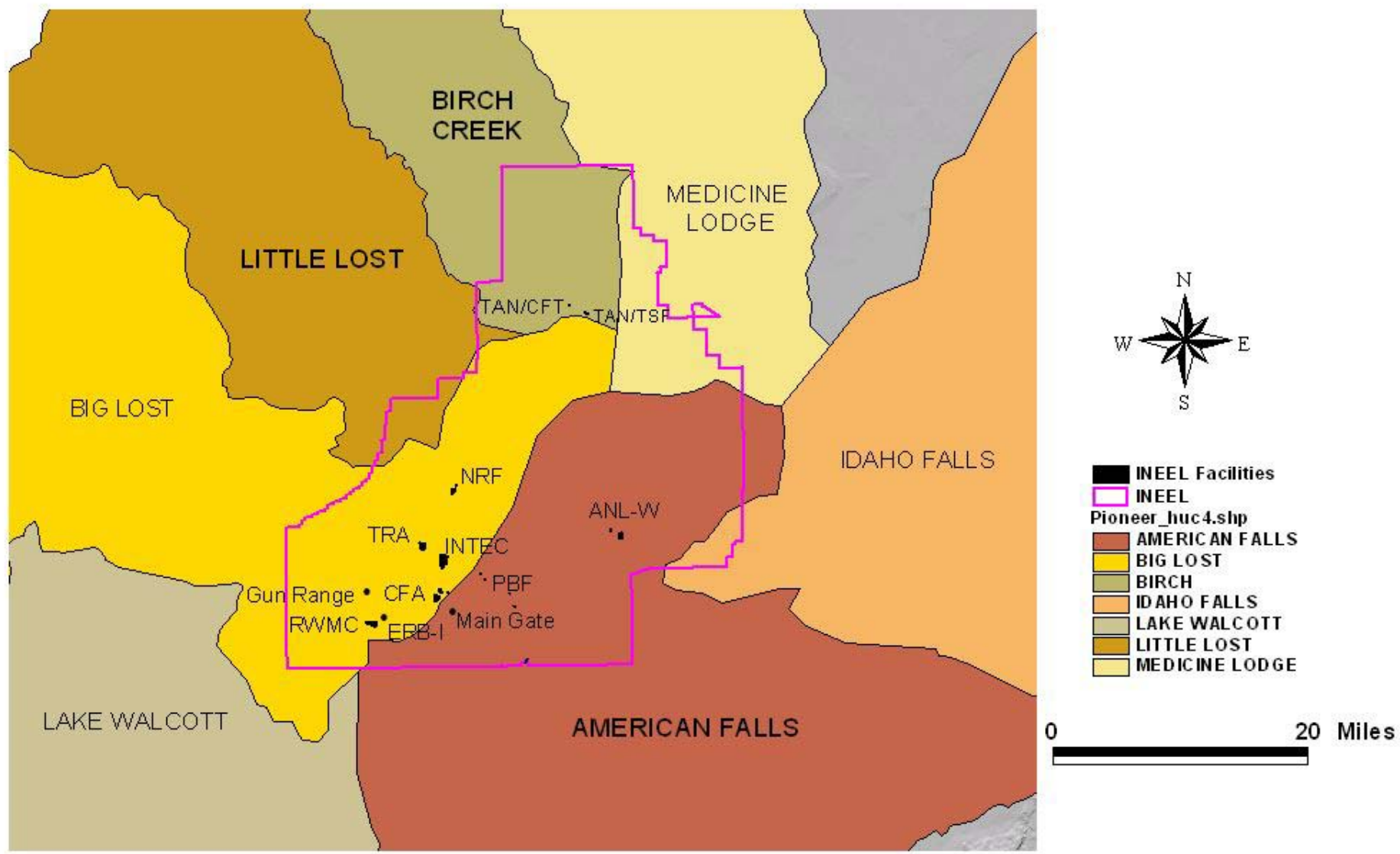

Figure 2-4. INEEL-related watersheds ("Pioneer Basins") and public drinking water system facilities. 


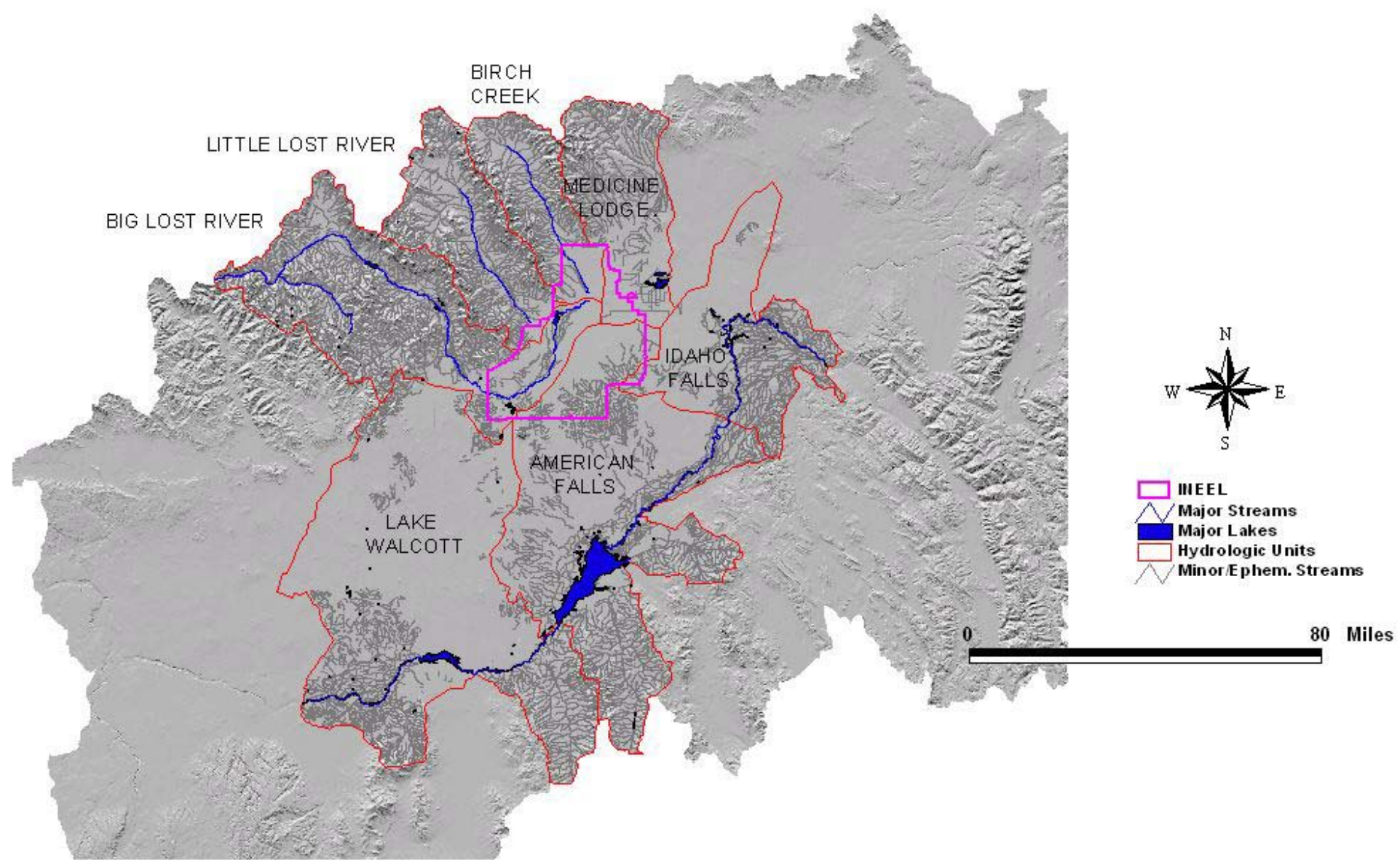

Figure 2-5. Pioneer Basin surface water resources. 


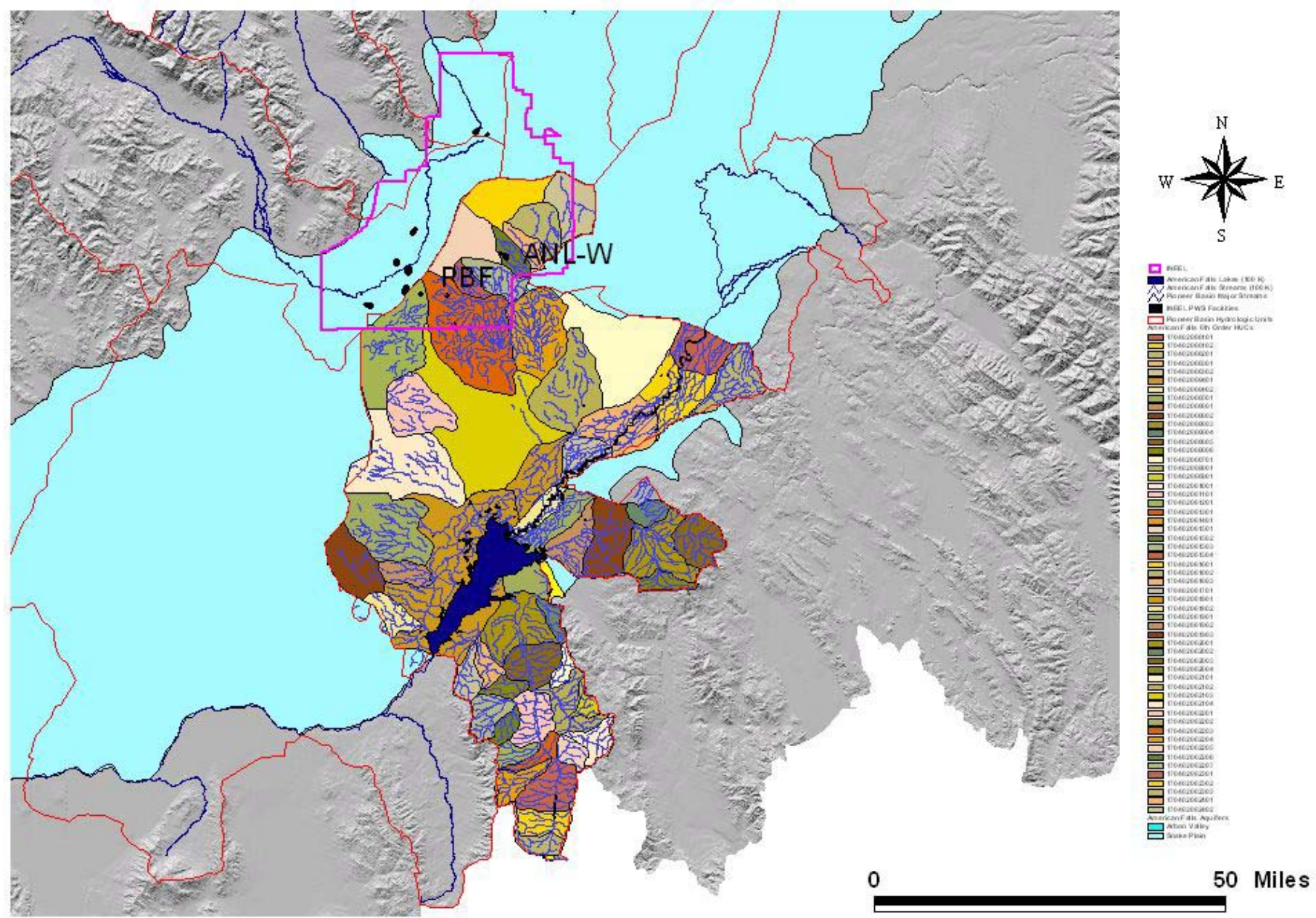

Figure 2-6. The American Falls Watershed. 
The geology and hydrology of the south side of the river is bounded on the east by the Blackfoot Mountains and on the south by the Deep Creek and Portneuf Mountains. These mountains consist primarily of sedimentary or metamorphic rocks such as shale, limestone, quartzite, and sandstone (USGS 1964). This land gently slopes from the mountains northerly or northwesterly to the Snake River.

In general, little precipitation falls in the American Falls Watershed. Therefore, there are few natural streams in this watershed and there are no permanent streams near the INEEL. South of the Snake River, there are numerous canals and a few streams near the Snake River. The most notable streams are the Blackfoot and Portnuef Rivers, and numerous small spring-fed streams issue from the Fort Hall bottoms, north of the town of Chubbuck, and Bannock Creek, just west of the Portneuf River drainage. However, the amount of flow from these is small, and almost all of the surface water available during the summer is diverted to irrigate the bottomlands. North of the Snake River, there are numerous canals near the river, but there are few streams of consequence. Most of the land in the northern and central portions of this unit near the INEEL is covered with sagebrush, exposed basalt, and a few irrigated farms. However, further south, closer to the Snake River, the land contains dry land and irrigated farms. Most of the bottomlands near the Snake River are irrigated.

Because of its distance and because the Snake River acts as a hydrologic divide for both surface water and groundwater flows, the hydrology of the south side of the river is distinct from the north side and does not directly affect the INEEL.

The northern portion of the watershed drains approximately 39\% of the INEEL, including around the ANL-W and PBF facilities. However, since there are no permanent streams near these facilities, no further surface water analysis is necessary for this watershed.

2.1.2.1.2 The Big Lost River Watershed (17040218)—The Big Lost River Basin includes the watershed drained by the Big Lost River and its tributaries and parts or all of three aquifers: Copper Basin, Big Lost River Valley, and the Snake River Plain (Figure 2-7). This watershed is one of the most developed watersheds and is one of the best-characterized tributary watersheds in the Pioneer Basin.

The Big Lost River Watershed is about 60 miles long and is flanked by numerous mountains: the Pioneer, Boulder, and White Cloud Mountains on the west and the Lost River Mountains on the north and east. The mountains' elevations range from 10,000-11,000 ft on the north side, 11,000-12,000 ft on the northeast side, and 8,000-10,000 ft on the south side of the basin. The Big Lost River Range consists of relatively highly faulted and folded limestone, shale, and related rocks. The Boulder Mountains are on the northwest. The Pioneer Mountains on the southwest primarily consist of Challis volcanics, including silicic and mafic flows, tuffs, and breccias that have been altered. The Big Lost River Valley opens to the eastern Snake River Plain on the southeast.

The valley floors of the headwater streams consist of glacial drift and fluvioglacial outwash. From the vicinity of Chilly and downstream, these deposits become much more extensive and they become interfingered with alluvial deposits from the surrounding mountains. The valley contains extensive alluvial deposits that are thought to be hundreds of feet deep. These deposits fill the valley floor to the mouth of the valley near Arco. Near Arco, these deposits are primarily sands and gravels intercalated with, and in some places overlain by, Snake River basalt. 


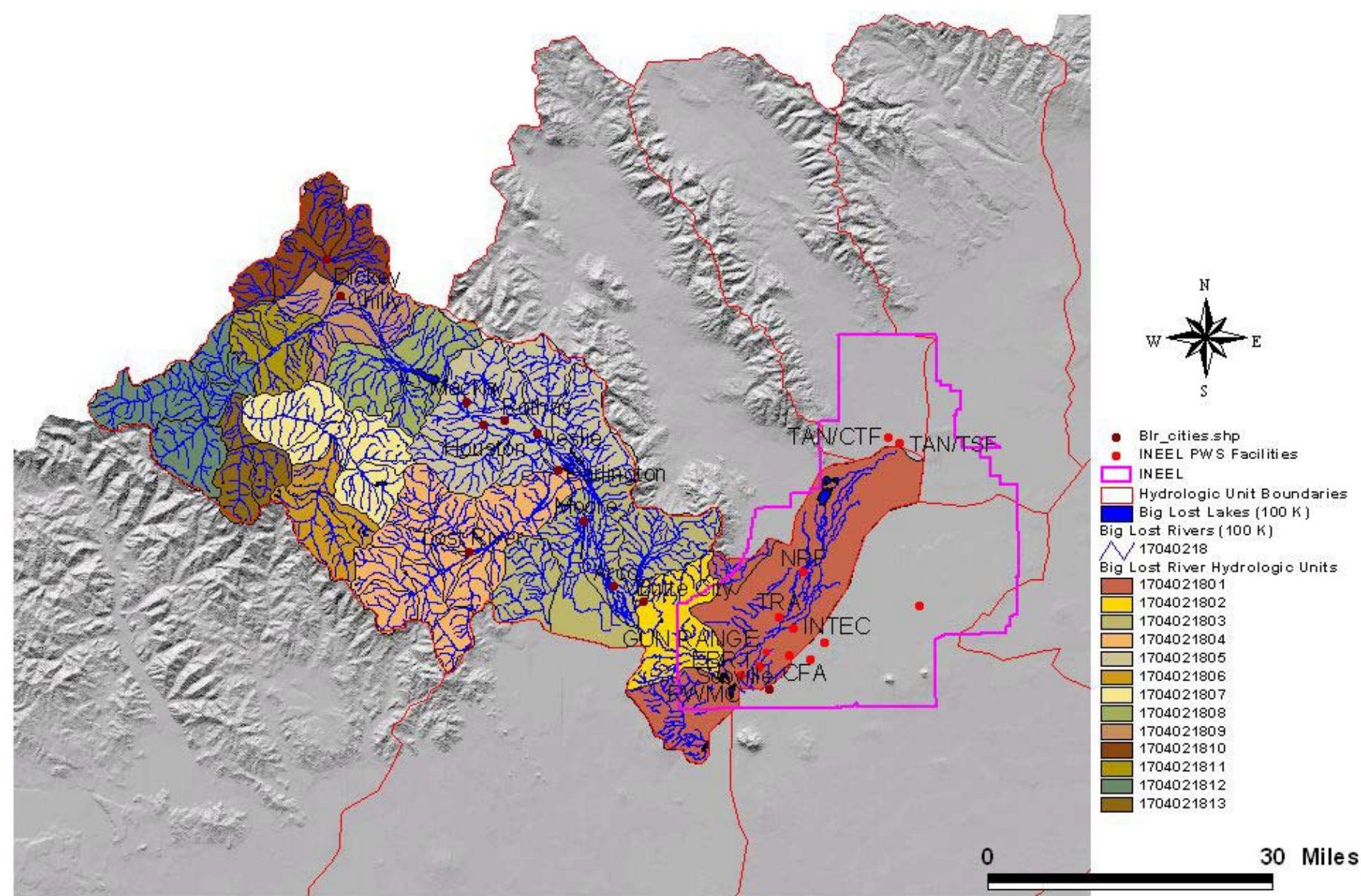

Figure 2-7. The Big Lost Watershed. 
The Big Lost River Watershed drains approximately $1,900 \mathrm{mi}^{2}$ of Idaho: approximately $1,400 \mathrm{mi}^{2}$ of the Big Lost River Valley and approximately $500 \mathrm{mi}^{2}$ of the eastern Snake River Plain. The Big Lost River is a gaining stream until approximately Howell Ranch. Primarily, it is either a perched or a losing stream downstream of Howell Ranch. The U.S. Environmental Protection Agency (EPA) lists 30 streams in the Big Lost River Watershed (EPA 2000) (Table 2-5), which DEQ further subdivides into 61 reaches for water quality purposes.

Table 2-5. EPA-listed streams in the Big Lost River Watershed (17040218).

\begin{tabular}{lllll}
\hline $\begin{array}{l}\text { Alder Creek } \\
\text { Antelope Creek }\end{array}$ & $\begin{array}{l}\text { Cherry Creek } \\
\text { Corral Creek }\end{array}$ & $\begin{array}{l}\text { Jones Creek } \\
\text { Kane Creek }\end{array}$ & $\begin{array}{l}\text { Mackay Reservoir } \\
\text { Pass Creek }\end{array}$ & $\begin{array}{l}\text { Summit Creek } \\
\text { Thousand Springs } \\
\text { Creek }\end{array}$ \\
& Dry Fork Creek & Lake Creek & Right Fork & $\begin{array}{l}\text { Twin Bridges } \\
\text { Creek }\end{array}$ \\
Big Lost River & Fall Creek & Leadbelt Creek & Rock Creek & $\begin{array}{l}\text { Warm Springs } \\
\text { Creek }\end{array}$ \\
Boone Creek & Fox Creek & Left Fork & Sage Creek & Wild Horse Creek \\
Cedar Creek & Iron Bog Creek & Lone Cedar Creek & Star Hope Creek & Willow Creek \\
\hline
\end{tabular}

The primary stream is the Big Lost River, and its primary tributaries are the East Fork of the Big Lost River (East Fork), the North Fork of the Big Lost River (North Fork), and Antelope Creek. The East Fork originates in the southern portion of Copper Basin, flows northward then northwestward to its confluence with Wild Horse Creek near the mouth of the Copper Basin where it then flows to its confluence with the North Fork. The North Fork originates in the Boulder Mountains near Ryan Peak, just north of Trail Creek Pass. It flows generally eastward for a short distance, deflects southeastward to its confluence with Summit Creek, then curves northeastward and flows to its confluence with the East Fork near the mouth of Copper Basin. This confluence is considered the beginning of the Big Lost River.

From the confluence of the East and North Forks, the Big Lost River flows northeasterly until it forks just southwest of the town of Chilly. In the Chilly area, there are a series of five sinks as follows:

- $\quad$ The first is a group of five large sinks, which are thought to be the remnants of a collapsed limestone cave that is thought to discharge to Thompson Spring, 5 miles to the southeast

- The next three sinks are areas where water flows into highly porous alluvial materials

- Next are the Chilly Sinks that start just southwest of Chilly and extend downstream for about 10 miles. The river must reach a flow of $750 \mathrm{cfs}$ in order to flow past these sinks.

A portion of the river continues northeasterly until it intersects Thousands Springs Creek about midway through the Chilly Sinks, the other fork flows southeast into the Mackay Reservoir. Between the Mackay Reservoir and Leslie, the groundwater table is above the river. Between Leslie and Darlington, the water table drops drastically and water is lost from the river in the Darlington sinks. Between the Moore Dam and about 1 mile upstream of Arco, the river flows through the Moore Sinks. When the groundwater table is high, most of the river flow remains in the channel. However, when the water table is low, it must flow approximately $200 \mathrm{cfs}$ at the Moore Dam to maintain a flow to Arco. The Big Lost River then flows southwesterly to its confluence with Antelope Creek. 
Antelope Creek heads south of Smiley Mountain in the southeastern portions of the Pioneer Mountains, and it flows northeastwardly past the town of Darlington and into the Big Lost River. Then, the Big Lost River flows southeastwardly, past the town of Arco, and onto the eastern Snake River Plain. Then, the Big Lost River flows eastward and then northeastwardly in a concave arch to its terminus in the Big Lost Sinks and Playas on the northern portion of the INEEL.

Flow in the Big Lost River at the INEEL boundary is usually diminished by evaporation, flow manipulation at Mackay Dam, irrigation diversions, and infiltration losses along the river channel. However, when runoff from the Big Lost River valley is heavy, flow may reach the INEEL at its southwest boundary. From this point, flow moves northeastward in the natural channel of the Big Lost River, terminating at the playas near TAN. When flow exceeds $377 \mathrm{cfs}$, some of the flow automatically is diverted from the channel to the INEEL spreading areas, located 2 miles northwest of RWMC. The diversion area consists of Spreading Areas A through D (Figure 2-8). When the Big Lost River reaches the INEEL, it constitutes an important source of localized recharge to the eastern Snake River Plain.

The Big Lost River Watershed drains approximately 34\% of the INEEL. It is the primary surface water drainage on the INEEL because it is the INEEL's largest source of surface water, and numerous key INEEL facilities are located along the Big Lost River corridor.

\subsection{Birch Creek Watershed (17040216)—The Birch Creek Basin includes:}

- $\quad$ Birch Creek Watershed

- $\quad$ Birch Creek Aquifer

- A portion of the eastern Snake River Plain Aquifer.

Little development has occurred in this basin and, therefore, it has not been well characterized hydrologically.

The Birch Creek Valley is the result of basin and range faulting. The Birch Creek Watershed is about 40 miles long and ranges from about 12 to 18 miles wide (Figure 2-9). It drains the eastern slopes of the Lemhi Mountains and the western slopes of the Bitterroot Mountains. These mountains rise to up to $10,000 \mathrm{ft}$ and consist primarily of consolidated Paleozoic limestone, sandstone, and shale. The valley floor ranges from 7 to 8 miles wide and is comprised primarily of Quaternary sedimentary and alluvial materials several thousands of feet thick; however, these materials have not been well characterized.

The pass between the Birch Creek and Lemhi River valleys is about 7,200 ft high and about $5,200 \mathrm{ft}$ high at the mouth of the Birch Creek Valley where the creek flows onto the eastern Snake River Plain. Historically, Snake River basalt dammed the valley, restricting the deposition of alluvial materials to above the dam. Therefore, there are extensive alluvial deposits above the natural dam and limited amounts below the dam. Consequently, the slope of the valley floor above the dam is about $25 \mathrm{ft}$ per mile, and below the dam it is about $60 \mathrm{ft}$ per mile.

The Birch Creek Watershed (17040216) drains approximately $692 \mathrm{mi}^{2}$ (Figure 2-9). Because the prevailing winds are out of the west and must travel over many mountain ranges, the precipitation is low, approximately $10 \mathrm{in} /$ year on the valley floor, and 15-17 in/year in the surrounding mountains. Birch Creek originates in the northern portion of the watershed and flows southeasterly for approximately 40 miles until it sinks into the Birch Creek playas on the northern portion of the INEEL. There are 


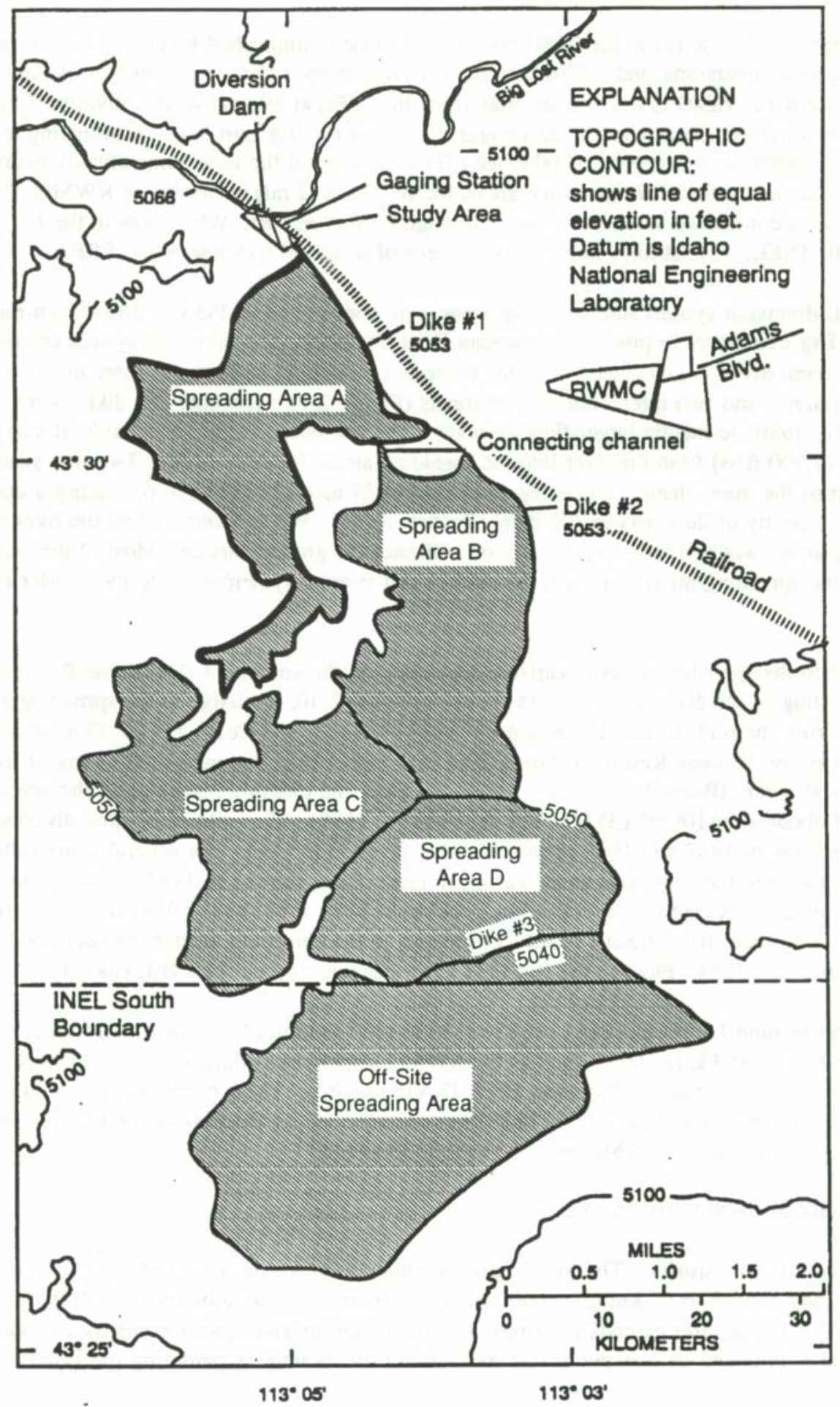

Figure 2-8. Big Lost River diversion and spreading areas (adapted from Bennett 1986). 


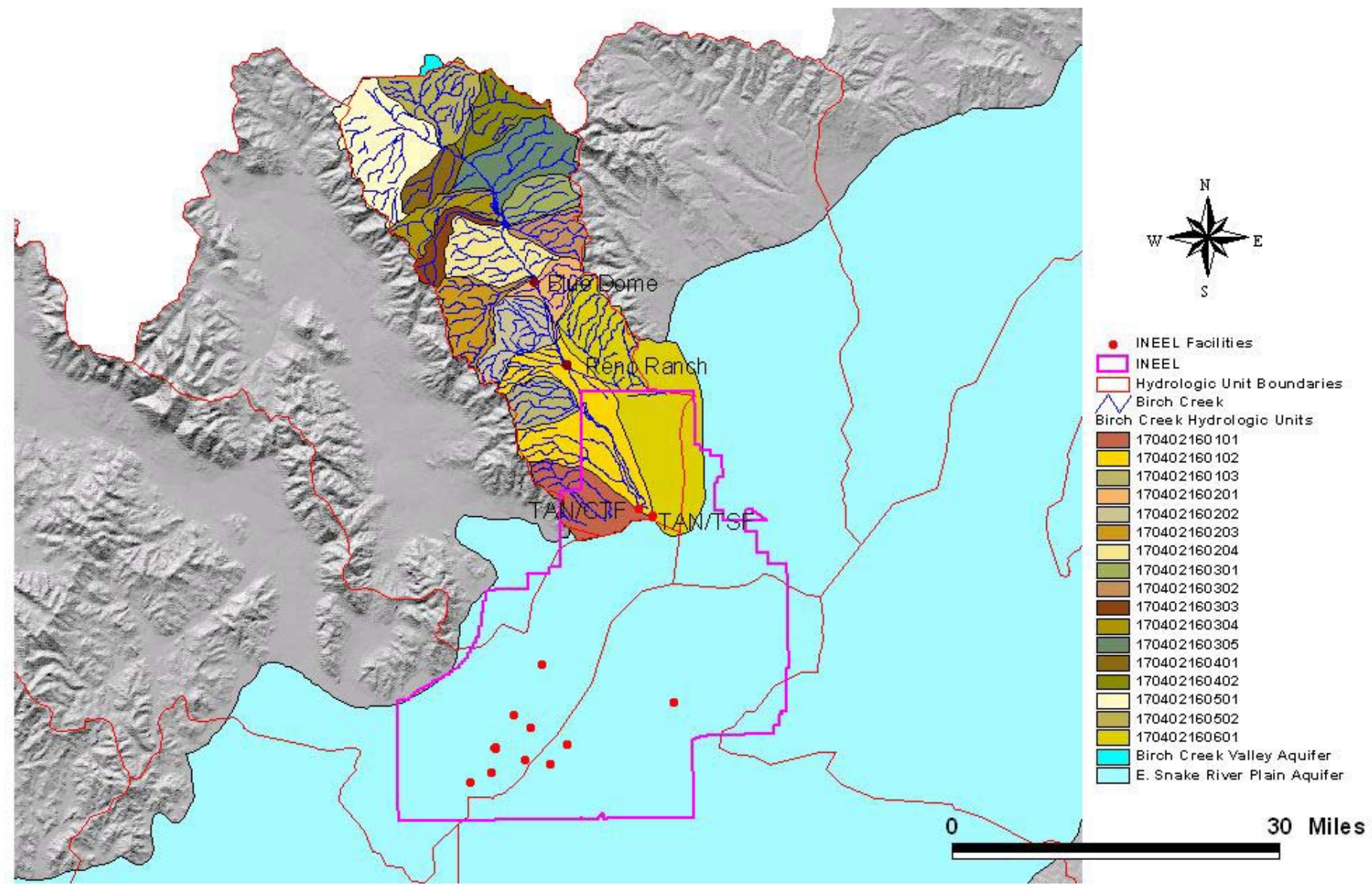

Figure 2-9. The Birch Creek Watershed. 
numerous tributaries on both sides of the valley; however, most of these tributaries lose their water via infiltration before reaching Birch Creek. EPA lists three streams within the watershed: Birch Creek, Pass Creek, and Willow Creek, and the state recognizes 16 stream reaches for water quality purposes.

Above Reno Ranch, the creek is intermittent and ephemeral. Near Reno Ranch, numerous springs discharge into Birch Creek; therefore, flow in this area is very uniform throughout the year and from year to year. Between the Reno gauging station and the INEEL boundary, the stream is diverted from its channel into the Reno Ranch hydropower plant, located several miles east of the natural channel. During the irrigation season, water flowing through the power plant is then applied to fields to irrigate crops. During the nonirrigation season, the water flowing through the power plant is then returned to the Birch Creek channel several miles downstream of the power plant. However, due to concerns about the potential of flooding of some buildings at TAN and to reduce the risk of potential future flooding, in 1969 the INEEL constructed some channels and began diverting the water to several gravel pits east of TAN. Most of the flow is lost to seepage in the lower portions of the valley before flowing onto the INEEL; however, water does flow onto the INEEL during high water years and sometimes when there is severe icing in the channel.

The Birch Creek Watershed drains approximately $14 \%$ of the INEEL. It directly affects only the facilities at TAN.

2.1.2.1.4 Idaho Falls Watershed (17040201)—The Idaho Falls Basin includes the Idaho Falls Watershed and the eastern Snake River Plain Aquifer. The watershed is about 97 miles long, 58 miles wide, and drains approximately $1,140 \mathrm{mi}^{2}$ of the eastern Snake River Plain east of the Beaver-Camas Watershed, southeast of the Birch Creek Watershed, and east of American Falls (Figure 2-10).

The surficial soils in this area range from wind deposited loesses, sands, and volcanic ash, to exposed weathered basalt. There are large quantities of sand in the northern portion of the watershed, which includes near St. Anthony. In addition, a large exposed lava ridge extends from the southeastern corner of the INEEL, east of ANL-W, in a northeasterly direction. Another ridge of lava, part of Hells Half Acre, extends from just outside the southeast corner of the INEEL toward the Idaho Falls and Blackfoot areas. This area is primarily underlain with Snake River Basalt.

Regionally, the Idaho Falls Watershed drains from the west and northwest toward Idaho Falls in the southeast corner of the watershed. The watershed elevation varies from about 5,400 ft in the southeastern corner of the INEEL to about 4,800 in the St. Anthony dunes area, to about 4,700 $\mathrm{ft}$ south of Idaho Falls. This eastern portion of the watershed is on the edge of the "Big Desert" area, and precipitation is low (i.e., 9-10 inches/year). Because of the low precipitation, there are few perennial sources of surface water, none on or near the INEEL. Those perennial surface water sources in this watershed occur in the eastern portion of the watershed near the Snake River. The only major surface water source in this watershed is the Snake River. The Snake River flows into the watershed from the southeast and flows northwest to its confluence with the Henrys Fork of the Snake River near the Menan Buttes and then arcs southward until it flows out of the watershed near the Woodville area. Only about $1 \%$ of the INEEL is in the Idaho Falls Watershed, and no INEEL facilities are located in this watershed. 


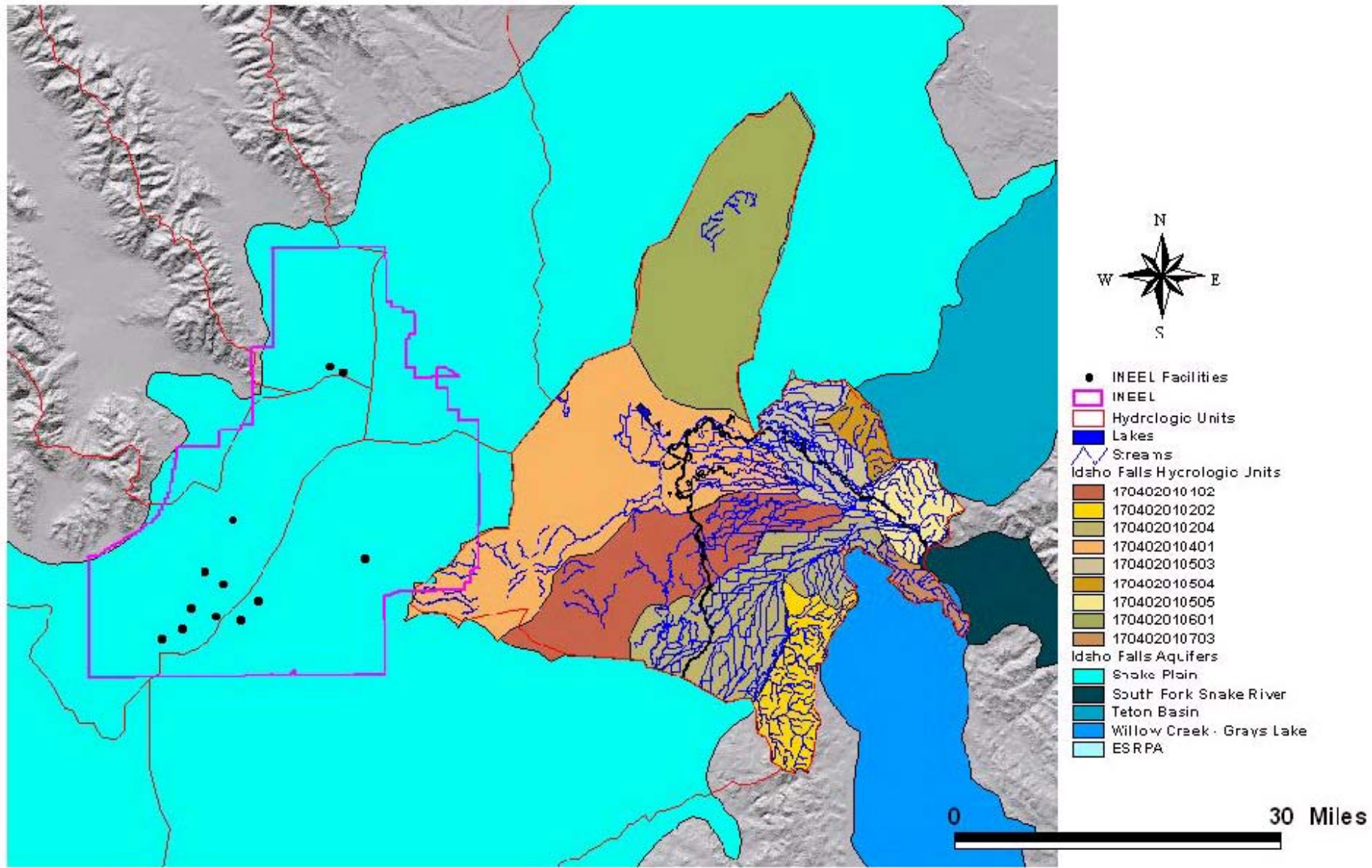

Figure 2-10. The Idaho Falls Watershed. 


\subsection{Little Lost River Watershed (17040217)—The Little Lost River Basin}

includes:

- $\quad$ Little Lost River Watershed

- $\quad$ Little Lost River Valley Aquifer

- $\quad$ Portion of the eastern Snake River Plain Aquifer.

There is little development in this watershed; therefore, it has not been well characterized hydrologically.

The Little Lost River Valley is approximately 55 miles long and ranges from 8-28 miles wide. It drains the eastern slopes of the Lost River Mountains and the western slopes of the Lemhi Mountains. These mountains consist primarily of quartzite and Paleozoic limestone and shale and range up to 10,000 to $12,000 \mathrm{ft}$ in elevation. The valley floor averages about 7 miles wide and slopes from approximately $6,500 \mathrm{ft}$ in the north to $4,800 \mathrm{ft}$ at the mouth of the valley. The valley floor consists primarily of Quaternary sediments, mostly layers of sand, gravel, and clay, with streaks of hardpan (mainly cemented gravel).

The Little Lost River Watershed drains $957 \mathrm{mi}^{2}$ of Idaho just east of the Big Lost River Valley (Figure 2-11). EPA lists 15 streams in the Little Lost River Basin (Table 2-6), which DEQ subdivides into 29 reaches for water quality purposes.

The Little Lost River originates at the confluence of Sawmill Creek and Summit Creek. Sawmill Creek heads in the Lemhi Range just east of Summit Pass and flows southeast to its confluence with Summit Creek. Summit Creek is a spring-fed creek that heads in the northwest portion of the basin. It is intermittent above its confluence with Sawmill Creek. Above the confluence of these creeks, the stream channel is rocky, and most water in Sawmill Creek remains within the channel. However, below the confluence of these streams, the channel material contains an increasing amount of alluvium, and, therefore, more water is lost to the subsurface.

Wet Creek and Dry Creek are the primary tributary streams to the Little Lost River. Both Wet Creek and Dry Creek originate in the Lost River Range north of Pass Creek Summit and flow northeastward to join the Little Lost River near Clyde. Although the other tributaries are, for the most part, perennial, they tend to percolate into the alluvium before joining the Little Lost River. Later, this groundwater discharges back to the Little Lost River maintaining the stream's base flow. The Little Lost River continues flowing south, southeastward from Clyde toward Howe, and then it terminates in the basalt of the eastern Snake River Plain just to the northwest of the INEEL. Stearns et al. (1938) indicate that the entire stream has been diverted in the Howe area since before 1938, and so the river no longer reaches the Little Lost Sinks.

The Little Lost Watershed drains approximately 3\% of the INEEL. However, this watershed does not include any INEEL facilities.

Table 2-6. EPA-listed streams in the Little Lost River Watershed (17040217).

\begin{tabular}{lllll}
\hline Badger Creek & Deer Creek & Hurst Creek & Summit Creek & Uncle Ike Creek \\
Bear Creek & Dry Creek & Little Lost River & Summit Res & Warm Creek \\
Deep Creek & Dry Creek Res & Squaw Creek & Timber Creek & Wet Creek \\
\hline
\end{tabular}




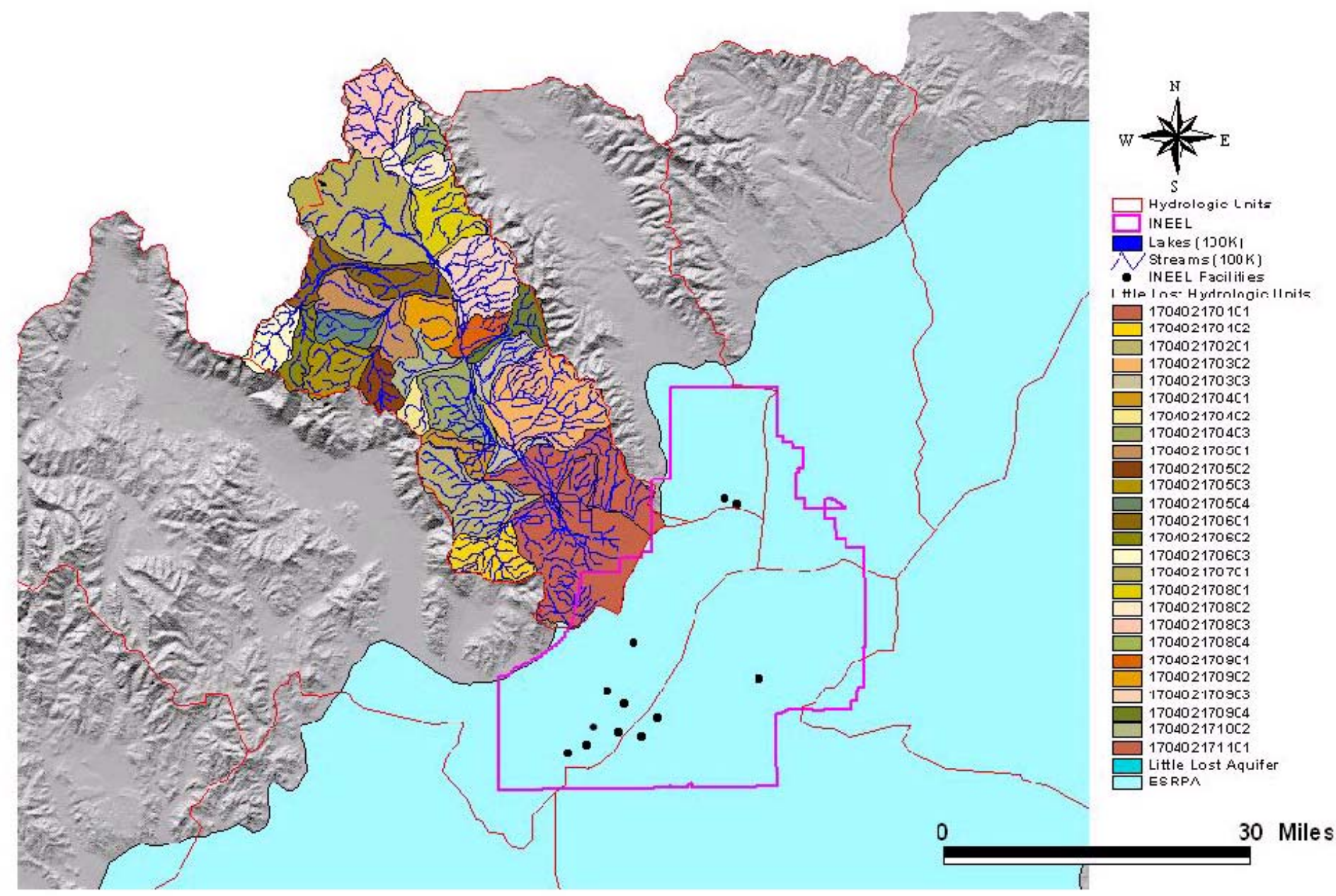

Figure 2-11. The Little Lost River Watershed. 
2.1.2.1.6 Medicine Lodge Watershed (17040215)—The Medicine Lodge Basin includes the Medicine Lodge Watershed and a portion of the eastern Snake River Plain Aquifer. Depending on the source of information, the Medicine Lodge Basin may or may not have a local aquifer.

The Medicine Lodge Valley is approximately 55 miles long and averages approximately 16-26 miles wide. It drains the southern slopes of the Beaverhead and Centennial Mountains, which range up to 8,000 and 11,000 ft in elevation. The Beaverhead and Centennial Mountains consist primarily of quartzite and Paleozoic limestone and shale, but some areas are underlain with ryolitic and other pyroclastic rocks, and other areas by sandstone and conglomerate rocks. The relatively high permeability of these materials probably accounts for the high levels of seepage to the subsurface and the fact that none of the streams heading in this subbasin flow far enough to reach Mud Lake.

The Medicine Lodge Watershed is east of Birch Creek Basin (Figure 2-12). The valley floor averages about 7 miles wide and slopes from approximately 6,500 ft in the north to 4,800 $\mathrm{ft}$ at the mouth of the valley. Within the headwater areas in the northern part of this basin, the streams are typically incised in narrow, rocky canyons. The southern part of the basin consists of a broad, flat basin containing several hundred square miles of land underlain by river alluvium and ancient lakebeds. The Medicine Lodge Watershed is a "closed basin" relative to surface water flow. Therefore, all discharges from this basin to the Snake River Plain are via eastern Snake River Plain Aquifer groundwater discharges (Stearns et al. 1938).

According to EPA, there are 13 streams in this unit (Table 2-7). Each of these streams quickly loses water via seepage until they "sink" into the eastern Snake River Plain Aquifer. The only significant stream in this unit is Medicine Lodge Creek. It is largely spring fed and originates from the southeastern portion of the Beaverhead Mountains. It then flows southeastwardly along the eastern boundary of this unit until it "sinks" into the eastern Snake River Plain between the towns of Small and Liddy Hot Springs.

Table 2-7. EPA-listed streams in the Medicine Lodge Watershed (17040215).

\begin{tabular}{lllll}
\hline Blue Creek & Dry Creek & Indian Creek & Middle Creek & Webber Creek \\
Crooked Creek & Edie Creek & Irving Creek & Mud Lake & \\
Deep Creek & Fritz Creek & Medicine Lodge Creek & Warm Springs Creek & \\
\hline
\end{tabular}

The most significant surface water resource in this watershed is Mud Lake, just north of Terreton. Mud Lake is recharged by Camas Creek, which flows in from the Beaver-Camas Subbasin (17040214), and by storing groundwater pumped by numerous wells from the eastern Snake River Plain Aquifer. Mud Lake is a 7,200-acre lake, which provides up to approximately 44,000 acre-ft of irrigation water in the Mud Lake-Terreton area.

The Medicine Lodge Watershed drains approximately $9 \%$ of the INEEL. However, it does not include any INEEL facilities.

2.1.2.2 Evaluation of Potential Surface Water Sources-The Big Lost River, Birch Creek, and Little Lost River have historically flowed onto the INEEL and terminated in "sinks" on the INEEL. The Big Lost River is the primary source of surface water recharge to the INEEL. In a typical year, the Big Lost River flows onto the INEEL, often to the TRA/INTEC area. During a high water year, it flows past these facilities and terminates in the Big Lost River sinks near TAN.

Depending on the water year, Birch Creek may flow onto the INEEL. However, due to upstream diversions, it usually is not a significant source of recharge to the INEEL. In high water years, Birch Creek flows onto the INEEL and sinks in the Birch Creek sinks near TAN. 


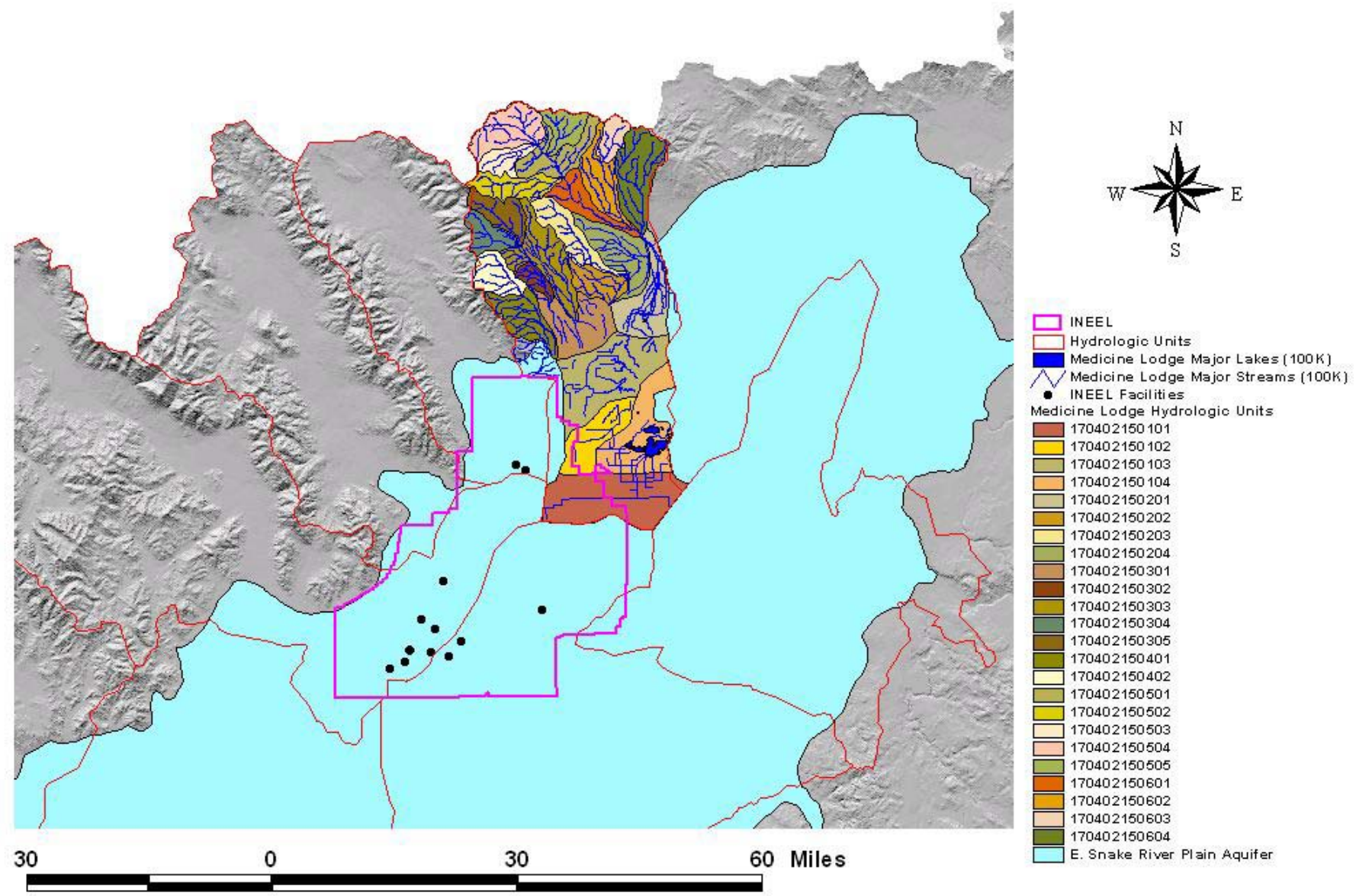

Figure 2-12. The Medicine Lodge Watershed. 
The Little Lost River is not considered a source of surface water to the INEEL; because of upstream diversions, the Little Lost River has not flowed on to the INEEL in recent history. During high water years, it could potentially flow onto the INEEL; however, since no INEEL facilities are in the vicinity of the Little Lost River, it is not an issue relative to source water assessments or protection.

Each of the streams that flow on the INEEL are "losing" streams once they flow onto the Snake River Plain. Therefore, to the extent that they flow near or on the INEEL, it can be assumed that they are hydraulically connected to the eastern Snake River Plain Aquifer.

The area on the INEEL that is drained by the Idaho Falls and Medicine Lodge Watersheds is relatively small, and no INEEL operations or facilities are within them. The Medicine Lodge Watershed drains a small area in the extreme northeastern part of the INEEL, and the Idaho Falls Watershed drains a small area in the extreme southeast corner of the INEEL. Generally, these areas should drain to the terminal outlets of their respective watershed - near Mud Lake and to the desert area between the INEEL and Idaho Falls respectively. However, there are no perennial streams in either watershed near the INEEL, and due to shallow topography, highly pervious soils and geology, and low quantities of precipitation, these areas drain to small closed basins that terminate on or near the boundaries of the INEEL. It is assumed that except in high water years, the majority of precipitation that falls on these areas infiltrates into the subsurface near where it falls or that it evaporates quickly back into the atmosphere.

The American Falls Watershed is a relatively large watershed just east and south of the Big Lost River Watershed. It drains approximately $39 \%$ of the INEEL and contains several major facilities, including ANL-W and PBF. Generally, this watershed drains to the south toward the Snake River and American Falls Reservoir. However, like Idaho Falls and Medicine Lodge Watersheds, there are no perennial streams in this watershed near the INEEL. During high water years, some water drains from the East and Middle Buttes toward ANL-W. However, in general, due to the shallow topography, highly pervious soils and geology, and low quantities of precipitation, the majority of precipitation that falls on these areas infiltrates directly into the shallow subsurface near where it falls and then evaporates or it evaporates directly from the surface back into the atmosphere.

Based on the surface water hydrology and the location of the INEEL's drinking water wells, the only watersheds that require further surface water assessments at the INEEL are the Big Lost River and Birch Creek Watersheds. Since both the Big Lost River and Birch Creek Watersheds are large watersheds (DEQ 1999), they will be delineated using the suggested Tier-II, Buffer Zone delineation method.

\subsubsection{Groundwater Delineations}

Each of the above watersheds is hydrologically interconnected with one or more of five total aquifers (Table 2-4 and Figure 2-13):

- $\quad$ Big Lost River Valley

- $\quad$ Birch Creek Valley

- $\quad$ Copper Basin

- $\quad$ Little Lost River Valley

- $\quad$ Eastern Snake River Plain. 


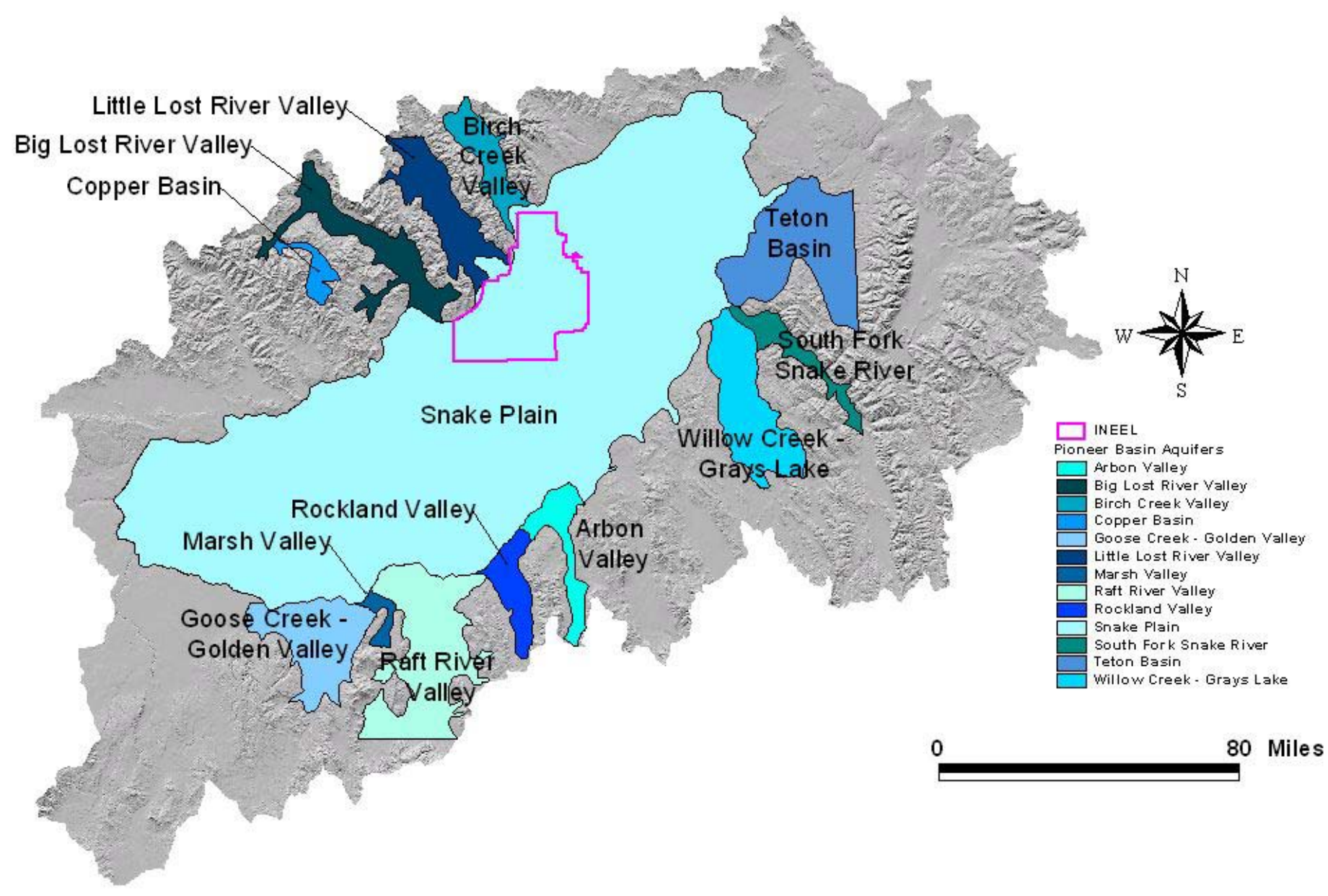

Figure 2-13. Pioneer Basins groundwater resources. 
Each of the tributary aquifers (and their surface water components) eventually discharges to the regional eastern Snake River Plain Aquifer. Therefore, their potential impact on the INEEL's public water systems must be evaluated.

The Big Lost River, Little Lost River, Birch Creek, and Medicine Lodge valleys are "northern tributaries" to the eastern Snake River Plain. They originate in the various mountain ranges north of the INEEL and each terminates in "sinks" and infiltrates into the eastern Snake River Plain Aquifer. Each of these streams flows in northward or northwestward trending valleys separated by high mountains. These mountains are comprised of a mixture of sedimentary and volcanic rocks, and the each of the valleys are, for the most part, filled to great depths with pervious alluvial materials (USGS 1964).

The base of the surrounding Basin and Range structures extend beneath the land surface into the eastern Snake River Plain (Robertson et al. 1974). For that reason, the exact boundaries between the eastern Snake River Plain Aquifer and the surrounding mountains/mountain valleys are not known. This is true concerning our knowledge of the exact boundaries of the tributary aquifers and boundaries between the various aquifers (e.g., the exact location where the Big Lost River Valley Aquifer ends and the eastern Snake River Plain Aquifer begins near Arco).

2.1.3.1 Big Lost River Aquifers. The Big Lost River Basin includes parts or all of three aquifers:

- $\quad$ Copper Basin

- $\quad$ Big Lost River Valley

- $\quad$ Eastern Snake River Plain.

The Copper Basin Aquifer drains the upper portion of the basin and provides recharge to the Big Lost River and Big Lost River Valley Aquifer. The Big Lost River Valley Aquifer drains much of the Big Lost River Valley and then recharges the eastern Snake River Plain Aquifer.

Approximately $652 \mathrm{mi}^{2}$ of the Big Lost River valley overlies Copper Basin and Big Lost River Valley Aquifers, and it overlies approximately $242 \mathrm{mi}^{2}$ of the eastern Snake River Plain Aquifer. The remainder of the Big Lost River Watershed opens up onto the eastern Snake River Plain. The primary aquifer is the unconsolidated alluvial aquifer, which is several thousand feet deep in some parts of the valley (Crosthwaite et al. 1970). Much of the alluvial aquifer is underlain by limestone, which also can transmit significant quantities of water. Near the mouth of the valley, the alluvial aquifer is intercalated with Snake River Aquifer basalt.

The materials making up the aquifers are moderately porous and permeable. Above Mackay Reservoir along the Big Lost River, these materials serve as a large underground reservoir, stabilizing inflow to the surface reservoir (Mundorf, Crosthwaite and Kilburn 1964). Downstream from Mackay Dam, the water table generally is below stream level, and the alluvium serves chiefly as a conduit for transmitting water underground from the basin into the Snake River Plain Aquifer. In general, the water table is near the land surface and mimics the land surface. The water table gradient averages about $25 \mathrm{ft} / \mathrm{mi}$ but is about 15-20 ft/mi near Chilly and between Moore and Arco, and it is steeper, about 30-40 ft/mi near Leslie and Darlington. The Big Lost River is considered by the Idaho Department of Water Resources to terminate near Arco at the so called "A" line (Figure 2-14). Because of the distance between the mouth of the Big Lost River Valley and the INEEL and the direction of both the Big Lost River Valley Aquifer and the eastern Snake River Plain Aquifer, groundwater flow from the Big Lost River Valley Aquifer has no impact on the INEEL. 


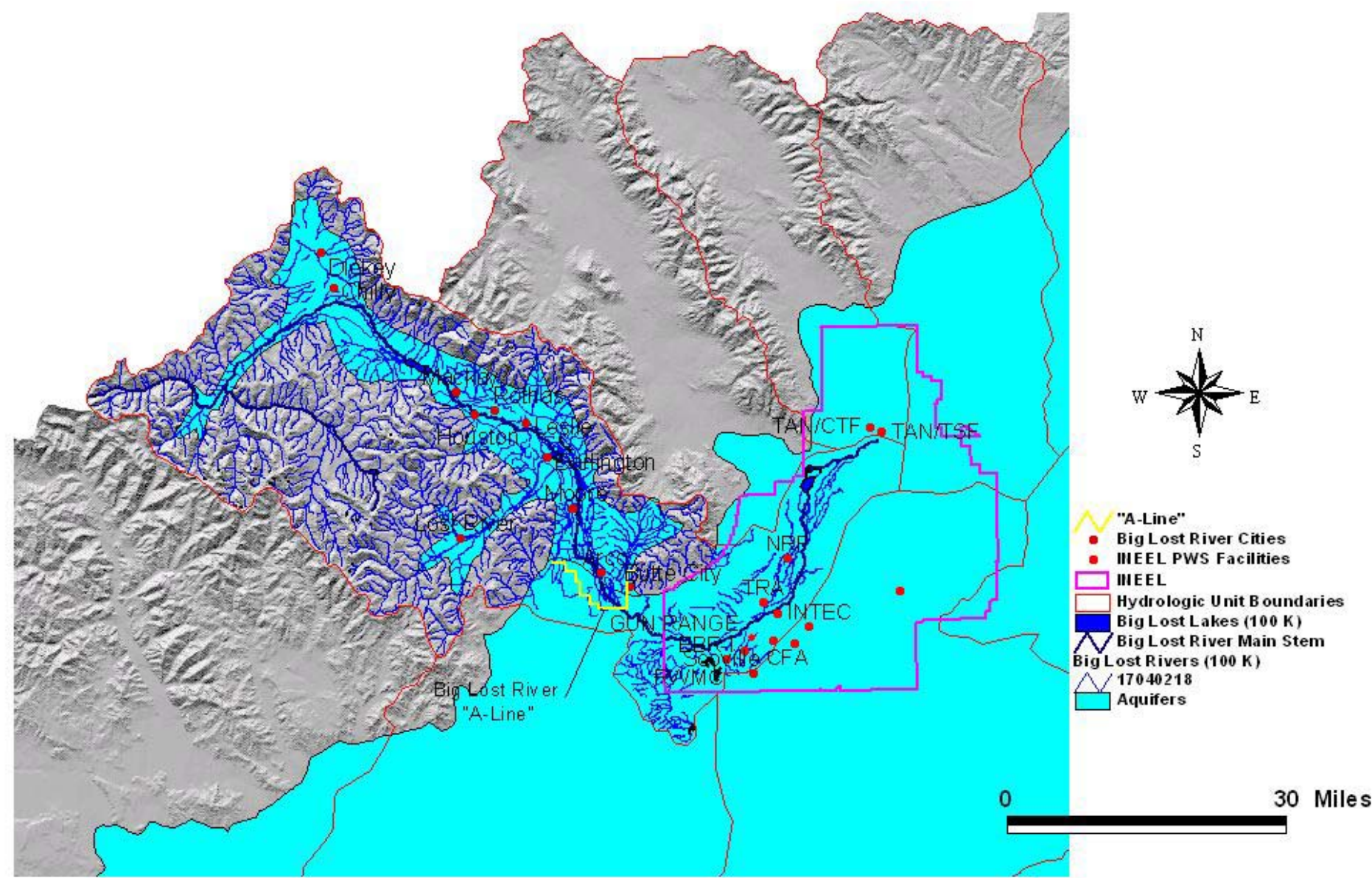

Figure 2-14. The "A" line near Arco. 
2.1.3.2 Birch Creek Valley Aquifer. The Birch Creek Watershed is underlain by the Birch Creek Aquifer, a 403- $\mathrm{mi}^{2}$ aquifer consisting of unconsolidated sand and gravel. In addition, the Birch Creek Watershed, near the mouth of the Birch Creek valley, is underlain by $32 \mathrm{mi}^{2}$ of the eastern Snake River Plain Aquifer.

The Birch Creek valley is deeply filled with alluvial materials; therefore, it serves both as an underground reservoir and groundwater conduit. Although the Birch Creek Valley Aquifer has not been well characterized because there is very little groundwater development in the valley, it is anticipated that the aquifer is very productive and capable of storing and yielding large quantities of groundwater.

2.1.3.3 Eastern Snake River Plain Aquifer. The eastern Snake River Plain Aquifer underlies the eastern segment of the Snake River Plain and extends from the Hagerman-Twin Falls area northeast toward the Yellowstone Plateau (Figure 2-15). It is approximately $200 \mathrm{mi}$ long and ranges from 30 to $60 \mathrm{mi}$ wide. The eastern Snake River Plain Aquifer is bounded on the northwest and southeast by the north-to northwest-trending fault-block mountains of the Basin and Range physiographic province.

The eastern Snake Rive Plain Aquifer is composed of a series of basalt flows interbedded with sediment of eolian, fluvial, and lacustrine origin. Basalt permeability is controlled by pore spaces and fractures. On a small scale (feet to hundreds of feet), the hydraulic properties of the basalt are nonuniform and highly variable, and the direction of groundwater movement at any given point within it is correspondingly variable and unpredictable. On a larger scale, however, the aquifer can be considered more homogeneous. The regional direction of flow within the aquifer generally is to the south and southwest, toward discharge points at springs along the Snake River in the Thousand Springs area. In 1988, approximately 4.3 million acre-ft of groundwater was discharged at these springs (Mann 1986).

The portion of the eastern Snake River Plain Aquifer beneath the INEEL is typical of the aquifer in general. The depth to the aquifer at the INEEL varies from about $200 \mathrm{ft}$ in the northern portion to more than $900 \mathrm{ft}$ at the INEEL's southeastern corner. As shown in Figure 2-15, the elevation of the water table in July 1999 was about 4,570 ft near TAN and about 4,440 ft near the RWMC. Groundwater below the INEEL flows south and southwest. The average gradient of the potentiometric surface was approximately $4 \mathrm{ft} / \mathrm{mi}$, and ranged from 1 to $15 \mathrm{ft} / \mathrm{mi}$. Data from Mundorff et al. (1964) indicate that groundwater flows about 2,000 cfs beneath the INEEL at its widest point. Aquifer transmissivity calculated for wells on the INEEL ranges from 4,000 to $2,400,000 \mathrm{ft}^{2} / \mathrm{d}$ (Robertson et al. 1974). The lowest transmissivities were reported from wells near TAN, and the highest were from wells near TRA. Typical transmissivity values at the INEEL range from 1.1 to $760,000 \mathrm{ft}^{2} / \mathrm{d}$ (Ackerman 1991). Storage coefficients range from 0.01 to 0.06 (Robertson et al. 1974).

Most groundwater flow takes place in the upper part of the aquifer. Mann (1986) concluded from data produced by the drilling of test well INEEL-1 that the effective base of the aquifer is 840 to $1,220 \mathrm{ft}$ below land surface. Since the depth to water near INEEL-1 is approximately $400 \mathrm{ft}$, Mann's interpretation suggests that the thickness of the effective portion of the aquifer is between 440 and $820 \mathrm{ft}$. The hydraulic conductivity of basalts in the upper $800 \mathrm{ft}$ of the aquifer ranges from approximately 1 to $100 \mathrm{ft} / \mathrm{d}$, generally diminishing with depth (Mann 1986). The hydraulic conductivity of the underlying material is much lower.

Inflow to the eastern Snake River Plain Aquifer beneath the INEEL is primarily by underflow from the northeastern part of the eastern Snake River Plain and by infiltration from the Big Lost River (Bennett 1990). Groundwater levels near the river are influenced by:

- $\quad$ Recharge from the Big Lost River when it flows onto the INEEL 


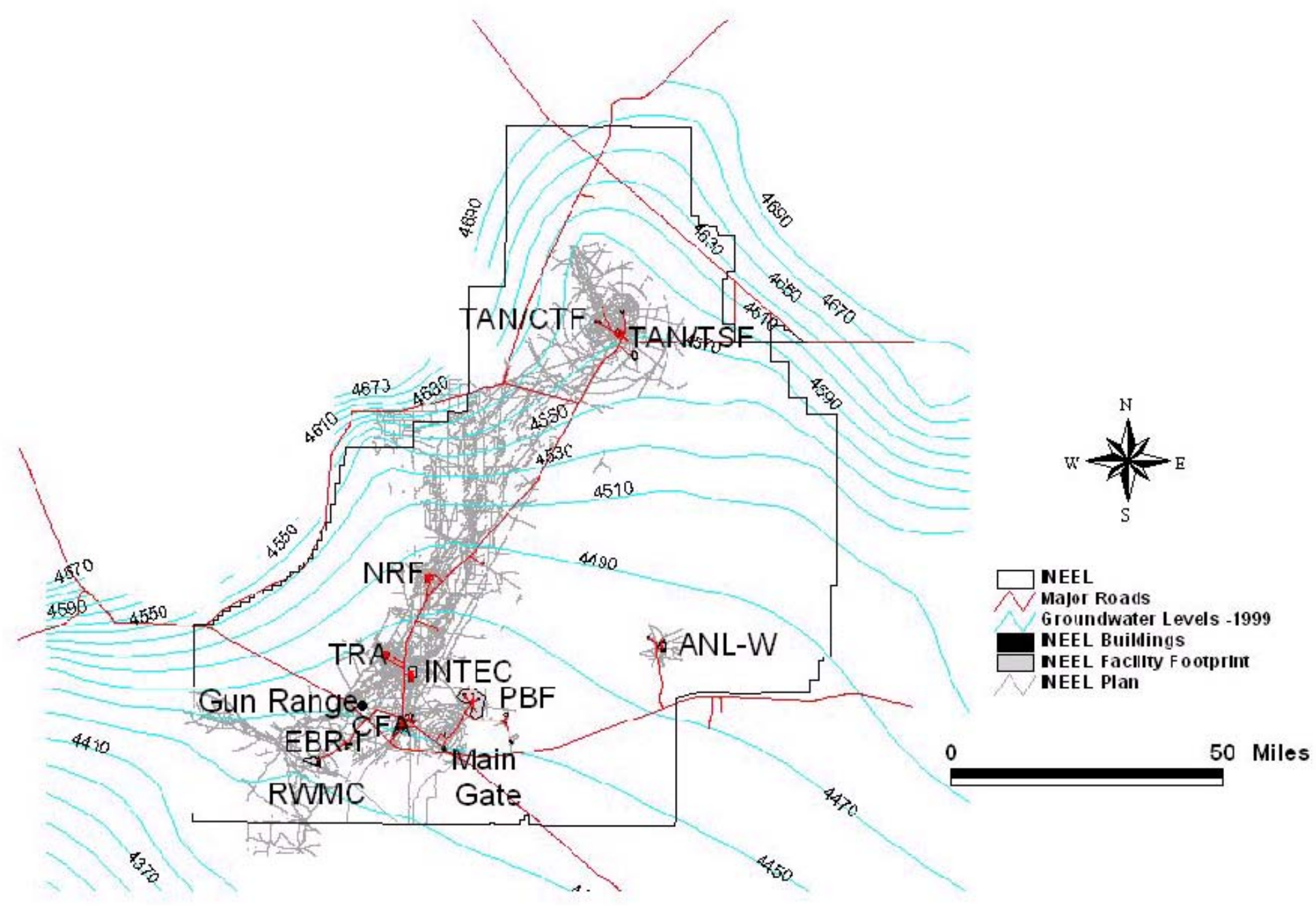

Figure 2-15. Elevation of the water table, Snake River Plain Aquifer (1999). 
- Infiltration from the Little Lost River and Birch Creek to the north and west also adds lesser amounts of recharge to the aquifer

- Infiltration of direct precipitation on the INEEL probably contributes a minor amount of recharge

- Withdrawals by pumping at the INEEL are small in comparison to the total volume of water stored in the aquifer and do not affect water levels significantly.

Perched water is groundwater separated from the underlying regional aquifer by an interval of unsaturated rock or sediment. Perched water exists beneath the INEEL where downward flow to the aquifer is impeded by layers of fine-grained sediments and by basalt flows with low permeability. Perched water exists below the Big Lost River and below wastewater discharge operations at TRA, INTEC, TAN, NRF, and rarely at ANL-W (as partially saturated zones).

2.1.3.4 Little Lost River Valley Aquifer. The Little Lost River Watershed is underlain by the $463 \mathrm{mi}^{2}$ Little Lost River Valley Aquifer. The Little Lost River Valley is comprised primarily of unconsolidated sand and gravel. Near the mouth of the valley, it is underlain by approximately $6 \mathrm{mi}^{2}$ of the eastern Snake River Plain Aquifer. Like the Big Lost River Valley, the Little Lost River Valley is underlain by relatively impermeable rock, in-filled with relatively permeable alluvial and fluvioglacial materials. These materials consist primarily of gravel and sand, but in some areas they are intercalated with clays and silts and other coarser materials. The water table is as follows:

- $\quad$ Above Wet Creek, the water table in the central portion of the valley is at or near the ground surface

- For about the next $17 \mathrm{mi}$, the river is thought to be perched above the aquifer except near Knollin Springs

- At about 9-11 mi above Howe, the water table comes up to the ground surface again due to a partial geologic barrier formed by a constriction in the consolidated rock of the valley walls

- $\quad$ Below this constriction, the water table becomes more steeply sloped, to about 30-80 ft below the land surface just north of Howe

- $\quad$ South, southeast of Howe, near Highway 22, the water table drops abruptly to approximately 250-300 ft, and the Little Lost River Aquifer's alluvial materials are intercalated with the basalts of the eastern Snake River Plain Aquifer.

2.1.3.5 Medicine Lodge Aquifer. Although the Idaho Department of Water Resources (Graham and Campbell 1986) does not list the Medicine Lodge basin as having a local aquifer, the EPA (2000) lists it as having approximately $650 \mathrm{mi}^{2}$ of aquifers $\left(433 \mathrm{mi}^{2}\right.$ of unconsolidated sand and gravel aquifer, $152 \mathrm{mi}^{2}$ overlying the Snake River Plain Aquifer, and $76 \mathrm{mi}^{2}$ of other volcanic- and sedimentary-rock aquifer). The difference appears to be due, in part, to the difference in how the basin is defined.

Mundorf et al. (1964) shows Crooked Creek and Warm Springs Creek to flow primarily over Pre-Tertiary rocks, and the remaining streams to primarily flow over Silicic volcanic and sedimentary rocks. Only the lower portion of Medicine Lodge Creek flows onto the Quanternary sedimentary materials (e.g., alluvial, and eolian deposits, glacial outwash, and lake bed deposits), associated with the northern margins of the eastern Snake River Plain and much of the area around Mud Lake. In this basin, the Snake River Plain Aquifer is north of Mud Lake and along the southern edge of the Medicine Lodge Watershed. 
In addition to surface and underground inflow from the streams, mass underflow probably is considerable into the Mud Lake area through moderately permeable conglomerate, sandstone, and volcanic rocks, which crop out in the surrounding mountains. Groundwater occurs in alluvium, basalt, loose volcanic cinders, and sedimentary strata associated with volcanic rocks. Most wells of large yield penetrate basalt or cinders. A geologic barrier extending west and northwest through the Mud Lake area holds the water table near the surface northeast of the barrier at an altitude of about 4,800 ft. To the southwest, the water table drops several hundred $\mathrm{ft}$ within a few miles.

\subsubsection{Facility-Specific Wellhead Protection Zones}

The INEEL receives direct groundwater recharge from three aquifers: the Birch Creek, the eastern Snake River Plain, and Little Lost River Aquifers. Although the Big Lost River is the primary source of surface water at the INEEL, groundwater flow from the Big Lost River Aquifer flows directly into the eastern Snake River Plain Aquifer just north of Arco, Idaho, well downgradient of the INEEL. Therefore, the INEEL does not receive any groundwater recharge from the Big Lost River Valley, but it does receive direct recharge from Big Lost River infiltration when the river flows onto the INEEL.

Although the Little Lost River does not flow onto the INEEL, the Little Lost River Aquifer flows into the eastern Snake River Plain Aquifer near Howe, Idaho, just northwest of the INEEL. However, there are no facilities or public water systems on the INEEL in this watershed.

The Birch Creek Aquifer flows into the eastern Snake River Aquifer just north of the INEEL and recharges the eastern Snake River Plain Aquifer near TAN. The Medicine Lodge, Idaho Falls, and American Falls Watersheds all overlie the eastern Snake River Plain Aquifer and, with the possible exception of localized perched water zones, the portions overlying the eastern Snake River Plain have no distinct local aquifer.

All INEEL's facilities are located directly over the eastern Snake River Plain. In addition, since there is sufficient distance between the tributary aquifers and the INEEL's wells, and there is sufficient groundwater monitoring between the tributary aquifers and the INEEL's facilities, the groundwater portion of this assessment is confined to delineating the eastern Snake River Plain Aquifer.

2.1.4.1 Initial Wellhead Protection Zone Delineations. The purpose of wellhead protection is to protect groundwater-based drinking water supplies from contamination. This is accomplished by managing operations or activities conducted in designated areas surrounding wellheads to minimize the introduction of contaminants into the underlying groundwater, which could then be drawn into the wells.

A prerequisite to managing a wellhead protection area is to delineate the area within which management is advisable. The approach that is generally taken is to delineate several zones surrounding the wellhead, with the management level applied in each zone varying depending on the zone's proximity to the well. The most restrictive protection measures are applied in the zone closest to the wellhead because a contaminant can travel from the release point through the aquifer to the well in a shorter time. Management and control measures are progressively less restrictive in more-distant protection zones.

2.1.4.1.1 Available Technical Approaches-Several technical approaches have been developed for the delineation of wellhead protection zones:

- The simplest approach is to define the multiple protection zones using a series of concentric circles centered on the well to be protected, with the radii of the circles calculated based on certain standardized assumptions about aquifer properties and pumping volumes 
- A more accurate approach is to apply an analytical model, which takes into account aquifer properties, flow direction, and gradient

- $\quad$ The third and most accurate approach is to use a numerical model, which takes into account variations in aquifer properties throughout the modeled domain and variations that occur over time, but which requires specific knowledge of the spatial and temporal variation of the variables.

The second approach, application of an analytical model, was adopted as the most appropriate choice for producing capture zone maps for production wells at the INEEL. This analysis was conducted using the RESSQC module of the EPA's Well Head Protection Area (WHPA) computer software program. Inputs to the program include aquifer transmissivity, porosity, and thickness; hydraulic gradient and flow angle; and pumping rate of the well. The output of the program is a map of the subject well's time-related capture zone, with the specific travel times selected by the user. For the maps presented in this report, travel times of 2 years and 5 years were selected.

2.1.4.1.2 INEEL-Specific Considerations-Generally in wellhead protection programs, capture zone maps such as those presented here are used to define the areas within which aquifer protection management measures are undertaken. This practice should be modified slightly at the INEEL to account for site-specific conditions.

For example, the vadose zone at the INEEL is unusually thick, around $500 \mathrm{ft}$ thick in many places. Because the vadose zone is so thick, and also because the alternation of basalt layers with sedimentary interbeds makes for large contrasts in permeability, contaminants have ample opportunity to migrate laterally between the surface point of release and the point where those contaminants reach the water table. This means that a contaminant released outside of a mapped capture zone may nonetheless have migrated into that capture zone by the time the contaminant reaches the aquifer. The areas within which special groundwater protection precautions should be undertaken may thus be somewhat larger than the areas enclosed by the capture zones. On the other hand, the time necessary for a contaminant to travel from the surface point of release to the well will be greater than indicated by the capture zone maps, since the maps produced using the analytical model account only for the time of travel within the aquifer, and not within the vadose zone.

Table 2-8 reports the values assumed for the major RESSQC program variables at each of the INEEL Public Water System facilities. The transmissivity values used in the model generally represent an average of values from one or more wells in the vicinity of each facility, including the production wells themselves where possible. Where facility-specific transmissivity values were not available, the widely-quoted value of $173,000 \mathrm{ft}^{2} /$ day was used (Robertson et al. 1974). Aquifer thickness of $250 \mathrm{ft}$ and porosity of 0.1 are widely accepted as typical for the INEEL and are assumed for all of the capture zone maps. Flow angles and gradients were measured from water table elevation maps. Most pumping rates were based on annualized pumping volumes as reported in the Industrial Waste Management Information System database, and information on well location and radius came from the INEEL Comprehensive Well Survey (Sehlke et al. 1993).

The flow angles in Table 2-8 represent the direction water is flowing, and are measured clockwise from due north, which is assigned a value of zero degrees. Thus a due-south flow direction would be 180 degrees. The value in the table was converted from the value actually input into the RESSQC model, which uses a different convention for measuring angles. In the model, the cardinal east direction is given a value of zero degrees, and values increase in a counterclockwise direction. Using the RESSQC convention, the due-south flow direction would be 270 degrees. 
Table 2-8. RESSQC program variables at each INEEL public water system facility.

\begin{tabular}{|c|c|c|c|c|c|c|c|c|c|c|c|c|}
\hline Facility & ANL & CFA & EBR-I & $\begin{array}{c}\text { GUN } \\
\text { RANGE }\end{array}$ & INTEC & $\begin{array}{l}\text { MAIN } \\
\text { GATE }\end{array}$ & NRF & $\mathrm{PBF}$ & RWMC & TAN/CTF & TAN/TSF & TRA \\
\hline \# Pumping wells & 2 & 2 & 1 & 1 & 2 & 1 & 2 & 2 & 1 & 2 & 2 & 3 \\
\hline Transmissivity $\left(\mathrm{ft}^{2} / \mathrm{d}\right)$ & 173,000 & 56,000 & 1,300 & 173,000 & 250,000 & 173,000 & 212,000 & 40,600 & 20,400 & 20,000 & 20,000 & 150,000 \\
\hline Hydraulic gradient & 0.0008 & 0.001 & 0.001 & 0.0005 & 0.001 & 0.001 & 0.0007 & 0.0006 & 0.0005 & 0.0002 & 0.0004 & 0.0003 \\
\hline Flow angle $^{\mathrm{a}}$ & 235 & 185 & 200 & 220 & 210 & 230 & 190 & 205 & 190 & 180 & 160 & 210 \\
\hline Well 1 Name & EBR II \#1 & CFA \#1 & EBR-I & $\begin{array}{c}\text { GUN } \\
\text { RANGE }\end{array}$ & CPP \#4 & $\begin{array}{l}\text { MAIN } \\
\text { GATE }\end{array}$ & NRF-2 & PBF \#1 & $\begin{array}{c}\text { RWMC } \\
\text { Prod } \\
\end{array}$ & CTF \#1 & TSF \#1 & TRA \#1 \\
\hline Pumping rate $\left(\mathrm{ft}^{3} / \mathrm{d}\right)$ & $13,000^{\mathrm{b}}$ & 16,700 & 200 & 200 & 3,100 & 3,900 & 44,800 & 1,400 & 3,500 & 3,400 & 3,100 & 74,000 \\
\hline Well radius (ft) & 0.75 & 0.67 & 0.58 & 0.25 & 0.67 & 0.5 & 0.67 & 1 & 0.58 & 0.75 & 1 & 0.75 \\
\hline Well 2 Name & EBR II \#2 & CFA \#2 & & & CPP \#5 & & NRF-3 & PBF \#2 & & CTF \#2 & TSF \#2 & TRA \#3 \\
\hline Pumping rate $\left(\mathrm{ft}^{3} / \mathrm{d}\right)$ & $13,000^{\mathrm{b}}$ & 41,800 & & & 1,100 & & 44,800 & 500 & & 3,500 & 6,900 & 72,200 \\
\hline Well radius $(\mathrm{ft})$ & 0.75 & 1 & & & 1 & & 0.67 & 0.73 & & 1 & 0.67 & 0.83 \\
\hline Well 3 Name & & & & & & & & & & & & TRA \#4 \\
\hline Well radius $(\mathrm{ft})$ & & & & & & & & & & & & 0.67 \\
\hline \multicolumn{12}{|c|}{ a. Measured clockwise from the north. } & \\
\hline
\end{tabular}


As the previous paragraphs imply, a single value for transmissivity, storativity, gradient, and flow direction is used for each RESSQC run. This means that it is assumed that each of these properties is constant throughout the modeled domain and that the aquifer is homogeneous. In fact, it is clear that considerable aquifer heterogeneity exists in the Snake River Plain Aquifer at the INEEL. Failure to account for this heterogeneity will result in inaccuracies in the capture zone maps produced under the assumption of homogeneity. Accepting these inaccuracies seems unavoidable, however, because although heterogeneity is known to exist, the actual distribution of aquifer properties beneath any given facility is largely unknown.

Just as the independent variables that are assumed constant by the model vary in space, some of those variables also vary over time, yielding additional differences between observed and modeled results. Flow directions in the aquifer beneath some INEEL facilities have changed significantly over time in response to changes in infiltration from surface water bodies.

The most striking known example of this at the INEEL occurs at RWMC. During multi-year dry periods, no flow occurs in the Big Lost River near RWMC, and the direction of groundwater flow in the aquifer is toward the southwest. However, during wet years in the mid-70s and mid-80s, water flowed in the channel of the Big Lost River and was also diverted from the main channel into the spreading areas southwest of RWMC. In response to the sudden increase in infiltration from the spreading areas, the "normal" dry-year flow pattern in the aquifer was reversed, and in the immediate vicinity of RWMC, the groundwater flowed temporarily toward the east. Along with this altered flow direction, the regional water table simultaneously rose, so that the effective thickness of the aquifer also changed. A consequence of the periodic change in aquifer flow directions at certain sites is that the specific capture zones shown in this report occupy only a fraction of the total area that could potentially be mapped as "capture zone" if all possible flow directions were considered.

When running the RESSQC model, production well pumping rates must be treated as if pumping were maintained at a steady rate throughout the year. In actual practice, most INEEL production wells are pumped at a significantly higher rate than the annualized rate for a short time each day, and then shut off for the rest of the day. It was suggested that the capture zones calculated using the assumption of a steady, annualized pumping rate might differ from the capture zones resulting from actual pumping practice. To test this possibility, several MODFLOW runs were made using values for aquifer properties and pumping rates similar to those used in the INEEL facility RESSQC runs. The 8-day duration of the runs is much less than the 2-year and 5-year travel times associated with the RESSQC capture zones, but still sufficient to demonstrate the relevant trends. For each combination of variables tested, two sets of MODFLOW runs were made. For both runs, the 8-day simulation was divided into 16 stress periods, with three time steps per period.

The first run was made assuming a steady annualized pumping rate and was meant to duplicate the assumptions used by the RESSQC model. For that run, all stress periods used the same pumping rate. For the second run, each day was split into a 1-hour pumping period and a 23-hour recovery period. The pumping rate assumed for the pumping period was sufficient to produce the same volume of water over the duration of the simulation as was done in the steady-rate version of the simulation. At each time step and stress period, head comparisons were made at nodes successively farther removed from the pumping node.

The results of the comparison are as follows. The head difference between the steady-pumping rate scenario and the variable pumping-rate scenario diminishes with distance from the pumping node. As the edge of the cone of depression is approached, the head difference appears to become insignificant, at least for the particular combinations of variables used in these simulations. It is concluded that differences between the two scenarios can be safely ignored, especially in view of inaccuracies associated with other 
simplifying assumptions that had to be made in applying RESSQC at the INEEL. However, this conclusion is based on only a few simulations using a small number of combinations of variables. A better way to evaluate the validity of the steady-pumping assumption would be to run a simulation using a model with a particle tracker.

A thick vadose zone, aquifer heterogeneity, changing flow directions, and nonsteady pumping are examples of areas in which the assumptions of the RESSQC analytical model are not fulfilled. The "real" 2- and 5-year capture zones associated with INEEL production wells may thus look significantly different from those calculated for this report.

Nevertheless, these inaccuracies have less significance at the INEEL than they might elsewhere. This is because all INEEL facilities, including those that handle large quantities of potential aquifer contaminants, are closely controlled and operated to prevent environmental degradation. Thus, there is little need to apply differing management stringency levels at different INEEL facilities depending on their setting with respect to capture zones. Therefore, precisely locating capture zones is less important than the main purpose of production well capture zone maps at INEEL, which is to identify areas in which construction of facilities with potential to cause groundwater contamination should be avoided. A secondary purpose is to identify those general areas in which releases of groundwater contaminants would immediately impact nearby production wells.

2.1.4.2 Modifications to the Initial Wellhead Protection Zone Delineations. The wellhead protection areas delineated for the INEEL drinking water and production wells are based upon the Refined Method (see Section 2.1). In 1995, the RESSQC Module of EPA's Wellhead Protection Area modeling code was selected for use from the list of modeling codes, and simple "capture zone" maps were generated for 2- and 5-year times of travel for each of the wells. In 1997, when work on the INEEL's Wellhead Protection Program was reinitiated, the previous capture zone maps were compared to DEQ's current Wellhead Protection Plan requirements. Changes and details highlighted in the Wellhead Protection Plan (basing protection area zones on 3-, 6-, and 10-year times of travel), requiring the use of the most conservative assumptions when faced with data uncertainties or ranges of values, and noting that the Wellhead Protection Area code assumes no lateral migration of contaminants through the vadose zone) implied that the capture zone maps prepared in 1995 no longer satisfy Wellhead Protection Plan requirements. Three options are: (1) adopt much larger protection areas via the use of one of the Basic Methods, (2) embark on an expensive mission to remodel the capture zones using a more complex code, or (3) modify the existing capture zone maps. The latter option was chosen.

Based on the recommendations and assistance from the INEEL Water Resources Committee, the capture zone maps were modified as follows:

- $\quad$ Protection areas were lengthened

- $\quad$ Protection areas were widened

- $\quad$ Protection areas were augmented

- $\quad$ Public water system at the Main Gate Facility system was delineated later

- Where the mapped protection areas of multiple wells intersect, the protection areas were combined and the wells were treated as a single well field.

First, the protection areas were lengthened by linearly extrapolating the 2- and 5-year time of travel capture zones to 3-, 6-, and 10-year times of travel. 
Second, the protection areas were widened by adopting flow angle "ranges," rather than the single, dominant flow angle used in the original capture zone maps. Based on information in the INEL Groundwater Monitoring Plan (DOE 1993) all INEEL facilities exhibit variation or uncertainty in aquifer flow angle ranging from $20^{\circ}$ to $90^{\circ}$. (Identified and documented in the Groundwater Monitoring Plan for the purpose of siting monitoring wells at INEEL facilities, these ranges are believed to represent conservative values.) Adopting these flow angle ranges as bounding guidelines in establishing the lateral boundaries of the protection areas, the resultant protection areas resemble a pie-shaped wedge.

Third, the protection areas were augmented with a circular zone surrounding the wellhead to account for uncertainties associated with a heterogeneous aquifer, a thick vadose zone, and lateral migration of contaminants prior to their entry to the aquifer. In the INEL Groundwater Monitoring Plan (DOE 1993), the monitoring network sections for each facility recognizes ample opportunity exists for lateral migration of contaminants through the vadose zone due to its thickness and fractured basalt structure. As a result, it defines the distance the "line of compliance" monitoring wells should be located from the potential contamination sources to capture any lateral migration. In effect, these distances provide a site-specific estimate of the potential for lateral movement of the contaminants through the vadose zone. Ranging from 500 to 4,000 ft, these distances represent the best facility-specific information available, and were adopted as the radii for the circular management zones around the wellheads.

Fourth, the public water system at the Main Gate Facility system was delineated later. Because the Main Gate Facility is a transient, noncommunity system isolated from all significant facilities or operations expected to impact water quality at the facility and because Idaho's initial Wellhead Protection Program was voluntary, it was initially considered but not delineated. Since Idaho's Source Water Protection Program is now mandatory for all public water systems, the INEEL conducted the necessary delineations and evaluations. However, because this system is a low-risk, transient, noncommunity system, the INEEL utilized the simplified delineation approach. Based on the DEQ's guidance, multiple protection zones using a series of concentric circles centered on the well to be protected, with the radii of the circles calculated based on certain standardized assumptions about aquifer properties and pumping volumes. Based on DEQ's table for calculating fixed radii in eastern Snake River Plain basalt (Table 2-2), and knowing that the peak pumping capacity of the Main Gate Facility well is $20 \mathrm{gpm}$, the fixed radii for this facility are $50,2,700,5,300$ and $8,800 \mathrm{ft}$.

Finally, as recommended by DEQ's plan, where the mapped protection areas of multiple wells intersect, the protection areas were combined and the wells were treated as a single well field. This resulted in a single wellhead protection area for each of the INEEL facilities within which drinking water or production wells are located. Table 2-9 lists the wells and summarizes the final specifications used in delineating the protection areas at each of the facilities, and Figure 2-16 shows the protection area zones and boundaries for the INEEL. Most of the INEEL's wellhead protection areas are common in shape and orientation, although some abnormalities exist. The significant abnormalities are discussed below.

As expected, protection area size varies when comparing one facility to another. This is largely the result of the variation in transmissivity values (which dictates protection area length) and groundwater flow angle range values (which dictates protection area width) across the INEEL. Close observation of this figure also reveals an apparent discrepancy: NRF and INTEC portray similar wellhead protection area characteristics, but TRA's protection area differs significantly in size and orientation, even though it overlaps that of INTEC. This is probably caused by facility-specific data being extrapolated to a larger region (local hydrologic conditions vary greatly in fractured basalt; when these localized conditions are projected over a larger area, it magnifies subtle differences in the data). Or, it may be indicative of the differences in effects of Big Lost River flows on the individual facilities. For example, when the Big Lost River flows, it may appear that the INTEC wells, which are located much closer to the Big Lost River, have a much greater aquifer transmissivity than TRA, when in fact they may just be reflecting the large 
Table 2-9. Summary of INEEL wellhead protection area delineation specifications.

\begin{tabular}{|c|c|c|c|c|c|c|}
\hline $\begin{array}{l}\text { FACILITY; } \\
\text { Well ID }\end{array}$ & $\begin{array}{c}\text { Zone } \\
1 \mathrm{~A}^{\mathrm{a}} \\
\text { Radius } \\
\text { (ft) }\end{array}$ & $\begin{array}{l}\text { Circular } \\
\text { Zone }^{\mathrm{b}} \\
\text { Radius } \\
(\mathrm{ft})\end{array}$ & $\begin{array}{l}\text { Boundary Angles }^{c} \\
\text { (degrees) }\end{array}$ & $\begin{array}{l}\text { Zone } 1 \mathrm{~B}^{\mathrm{d}} \\
\text { Length } \\
(\mathrm{ft})\end{array}$ & $\begin{array}{c}\text { Zone } 2^{\mathrm{e}} \\
\text { Length } \\
(\mathrm{ft})\end{array}$ & $\begin{array}{c}\text { Zone } 3^{\mathrm{f}} \\
\text { Length } \\
(\mathrm{ft})\end{array}$ \\
\hline ANL-W; EBR-II \#1 \& \#2 & 50 & $500^{\mathrm{g}}$ & $\begin{array}{l}\text { 20-degree span from } \\
45-65 \text { degrees }\end{array}$ & 6,200 & 12,400 & 20,000 \\
\hline CFA; CFA \#1 \& \#2 & 50 & 1,000 & $\begin{array}{l}\text { 35-degree span from } \\
0-35 \text { degrees }\end{array}$ & 2,833 & 5,667 & 9,000 \\
\hline EBR-I; EBR-I & 50 & 500 & $\begin{array}{l}\text { 360-degree span from } \\
0-360 \text { degrees }\end{array}$ & 150 & 300 & 500 \\
\hline $\begin{array}{l}\text { Gun Range; Gun Range } \\
\text { Well }\end{array}$ & 50 & $500^{\mathrm{g}}$ & $\begin{array}{l}\text { 80-degree span from } \\
0-80 \text { degrees }\end{array}$ & 3,767 & 7,533 & 12,600 \\
\hline INTEC; CPP \#4 \& \#5 & 50 & 4,000 & $\begin{array}{l}\text { 90-degree span from } \\
325-55 \text { degrees }\end{array}$ & 11,533 & 23,067 & 38,000 \\
\hline $\begin{array}{l}\text { Main Gate Facility: Main } \\
\text { Gate Well }\end{array}$ & 50 & $500^{\mathrm{g}}$ & NA (Simplified Radii) & 2,700 & 5,300 & 8,800 \\
\hline NRF; NRF-2, \& -3 & 50 & $500^{\mathrm{g}}$ & $\begin{array}{l}\text { 60-degree span from } \\
330-30 \text { degrees }\end{array}$ & 6,700 & 13,400 & 22,400 \\
\hline PBF; PBF \#1 \& \#2 & 50 & 500 & $\begin{array}{l}\text { 30-degree span from } \\
25-55 \text { degrees }\end{array}$ & 1,087 & 2,173 & 3,600 \\
\hline RWMC; RWMC Well & 50 & 2,000 & $\begin{array}{l}\text { 360-degree span from } \\
0-360 \text { degrees }\end{array}$ & 600 & 1,200 & 2,000 \\
\hline TAN-CTF; CTF \#1 \& \#2 & 50 & 500 & $\begin{array}{l}\text { 140-degree span from } \\
270-55 \text { degrees }\end{array}$ & 500 & 800 & 1,200 \\
\hline TAN-TSF; TSF \#1 \& \#2 & 50 & 500 & $\begin{array}{l}\text { 115-degree span from } \\
270-25 \text { degrees }\end{array}$ & 667 & 1,333 & 2,000 \\
\hline TRA; TRA \#1, \#3, \& \#4 & 50 & 1,000 & $\begin{array}{l}\text { 30-degree span from } \\
30-60 \text { degrees }\end{array}$ & 3,067 & 6,133 & 9,200 \\
\hline \multicolumn{7}{|c|}{$\begin{array}{l}\text { b. Circular protection zone for the lateral migration of contaminants within the vadose zone, based on information in the "INEL Groundwater } \\
\text { Monitoring Plan." }\end{array}$} \\
\hline \multicolumn{7}{|c|}{ c. Lateral protection area boundaries measured clockwise from due north. } \\
\hline \multicolumn{7}{|c|}{ d. Estimated distance for a 3-year time of travel in the aquifer. } \\
\hline \multicolumn{7}{|c|}{ e. Estimated distance for a 6-year time of travel in the aquifer. } \\
\hline \multicolumn{7}{|c|}{ f. Estimated distance for a 10-year time of travel in the aquifer. } \\
\hline g. The "INEL Groundwater Moni & & identify a dis & for these focilitios $500 \mathrm{ft}$ & the & & \\
\hline
\end{tabular}




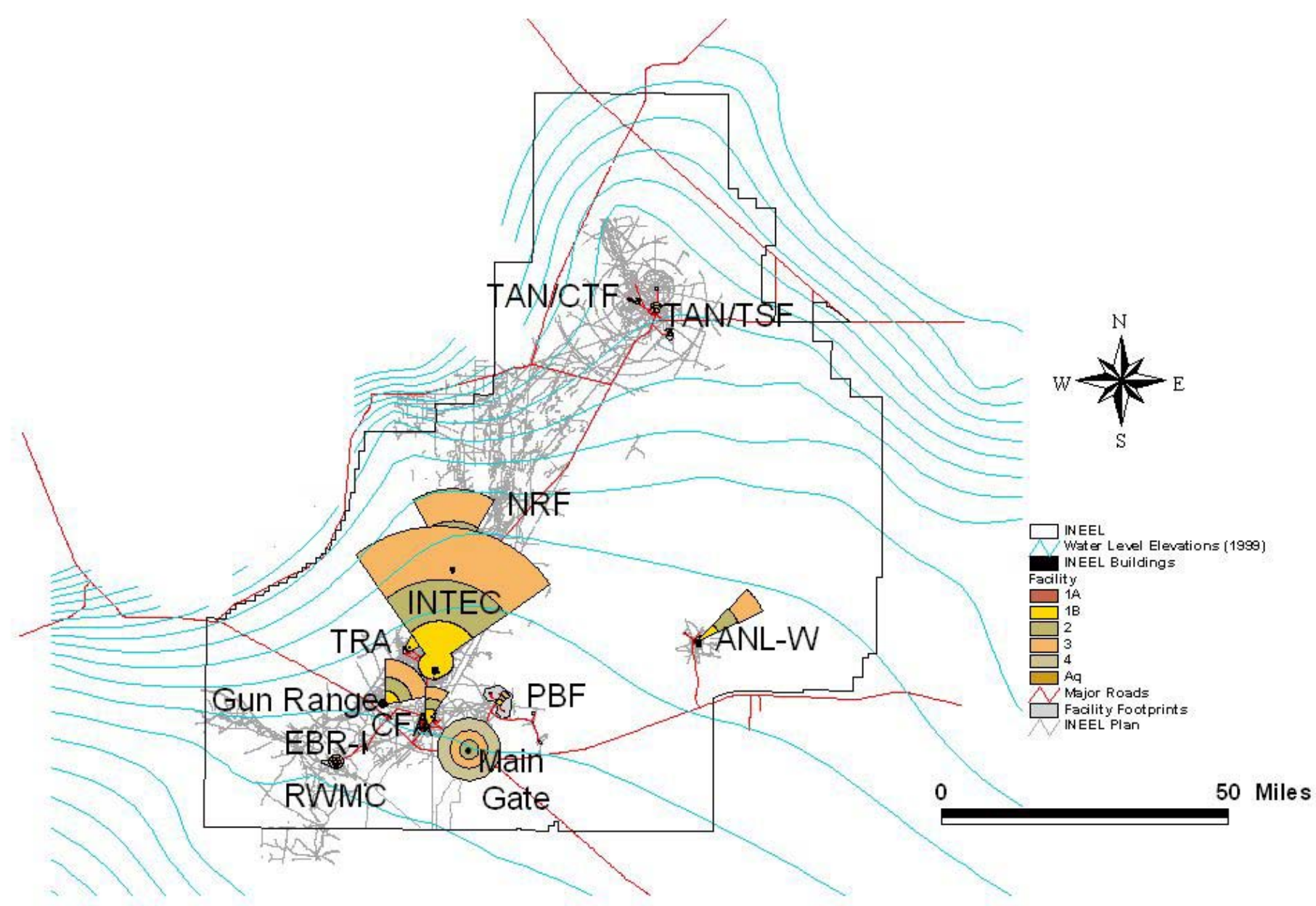

Figure 2-16. INEEL wellhead protection zones. 
impact of river recharge on the well. These differences do not necessarily indicate an error in the development of the protection area for TRA, but more likely reflect the degree of uncertainty associated with establishing the protection areas for NRF and INTEC. As a result, no changes to the protection area maps were made to reflect "consistency."

The EBR-I, Main Gate Facility, and RWMC wellhead protection areas are circular rather than the characteristic wedge-shaped. For EBR-I and the RWMC, this is due to the low transmissivity values measured at each facility, resulting in relatively short distances modeled for 10-year times of travel (296 ft for EBR-I and 1,800 ft for RWMC). In both cases, the distance for the "potential for lateral movement of contaminants through the vadose zone" exceeds the linear distance for the 10 -year time of travel.

As a result, the circular zone placed around the wellhead to account for lateral contaminant movement in the vadose zone is the dominant feature and was designated the protection area boundary for both maps. (Consistent with this boundary designation, the lines marking Zones 1B and 2 were adjusted accordingly.) This technique is supported at RWMC by the fact that contaminants believed to have originated in the Subsurface Disposal Area (which is not within the flow angle range measured at the RWMC) have been detected at the wellhead. The circular protection area at the Main Gate Facility is a result of using the simplified delineation method.

The INTEC wellhead protection area is notable simply for its size. Covering approximately 40 square miles and enveloping the NRF facility, this protection area is influenced by the high transmissivity values measured at INTEC and a wide aquifer flow angle range, which is probably due to the influence of the Big Lost River. This protection area also has the largest circular zone surrounding the wellheads, due to a history of significant contaminant movement along the perched water zones below INTEC. For example, contaminants believed to have originated south of the wells and outside the groundwater flow angle range for INTEC have been detected in the INTEC Production Wells CPP-01 and CPP-02. As noted previously, the boundaries for this wellhead protection area are based on the INTEC-specific information. Projecting these conditions over a larger area to establish boundaries for the INTEC wellhead protection area likely resulted in a very conservatively sized protection area, but also reflects the lack of information available on the area between INTEC and NRF.

The rest of the wellhead protection areas, as shown in the remaining the figures, are very similar in nature and exhibit no notable abnormalities.

\subsubsection{3Ｉndividual Facility Map Descriptions}

\subsection{Argonne National Laboratory-West Drinking Water Wellhead Protection}

Areas-Figure 2-17 shows the wellhead protection area and capture zones for Argonne National Laboratory-West's (ANL-W's) two drinking water/production wells. The RESSQC Module capture zones are long and thin, which in this case, are mostly due to the relatively high average transmissivity reported for wells in this area and a relatively stable groundwater flow direction. The groundwater flows generally to the southwest, and the orientation of the long dimension of the capture zones is toward the northeast, roughly normal to the water level contours in the area. For both wells, the boundary angles for the wellhead protection area are 45-65 degrees; and maximum distance of the 3-year capture zone is approximately $6,200 \mathrm{ft}$, the 6 -year capture zone is $12,400 \mathrm{ft}$, and the 10 -year capture zone is $20,000 \mathrm{ft}$ from each well. 


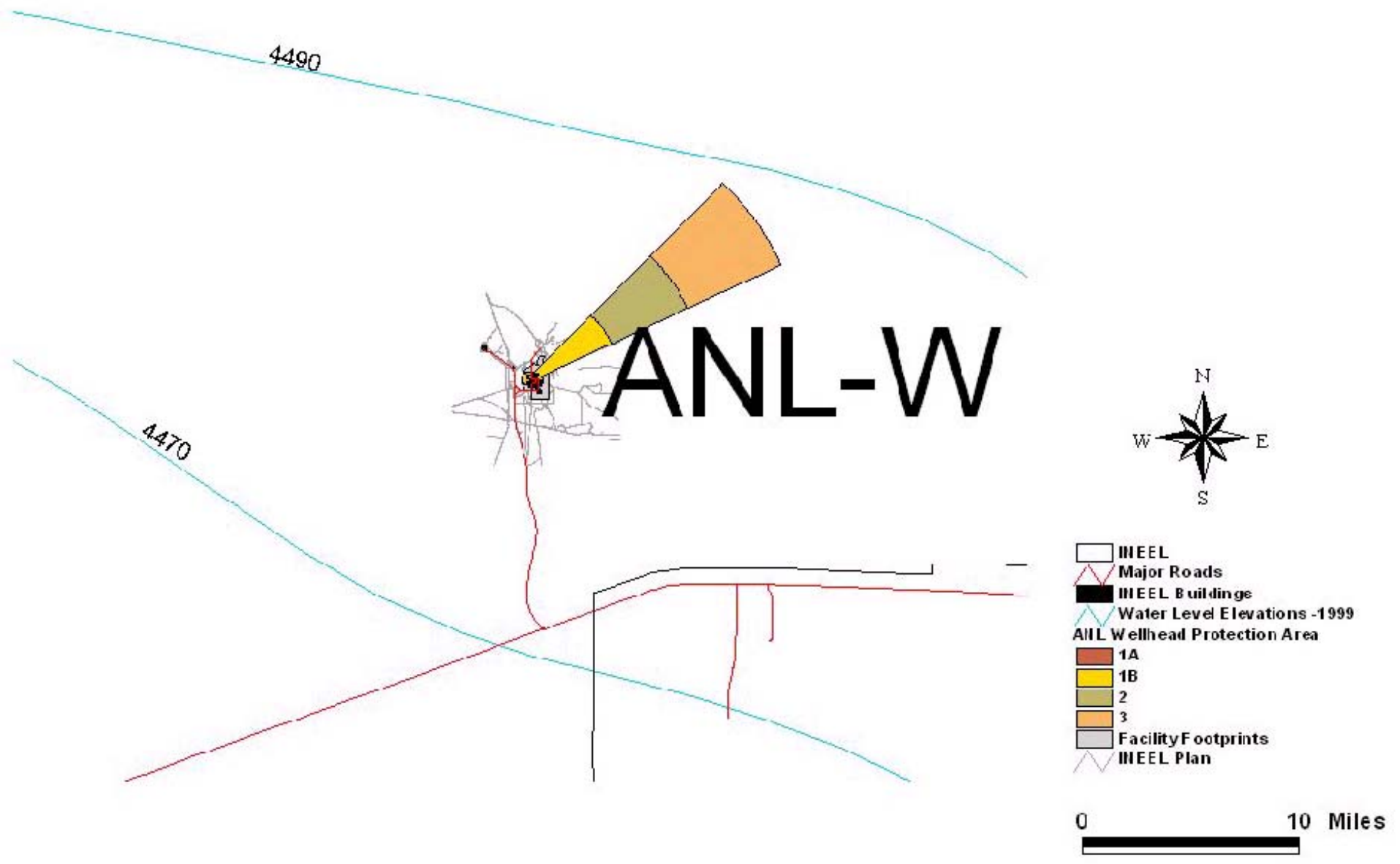

Figure 2-17. Argonne National Laboratory-West drinking water wellhead protection areas. 


\subsection{Central Facilities Area Drinking Water Wellhead Protection Areas-}

Figure 2-18 shows the wellhead protection area and capture zones for the two CFA drinking water/production wells. As the map shows, the groundwater flows generally to the south, and, therefore, the capture zones extend northward from the CFA production wells. Although the RESSQC Module capture zones of the two wells were similar in length, the capture zone for well CFA-2 is broader than that for well CFA-1. This is because a significantly larger volume of water is typically pumped from CFA- 2 . The wellhead protection area boundary angles for CFA are 0-35 degrees; and the maximum distance of the 3-year capture zone for both CFA wells is $2,833 \mathrm{ft}$; the 6 -year capture zones are $5,667 \mathrm{ft}$, and the 10 -year capture zones are 9,000 ft long.

\subsection{Experimental Breeder Reactor-I Drinking Water Wellhead Protection}

Areas-Figure 2-19 shows the wellhead protection area and capture zones for well EBR-I. In comparison with the capture zones at ANL-W and CFA, the RESSQC capture zones are small and broad. The shape of the capture zones is partly a function of the transmissivity value used in the calculations; the transmissivity as measured by a pumping test of EBR-I is unusually low for the Snake River Plain Aquifer. The small zones are also due to the small volume of water annually pumped from the well. Since the modeled capture zones were less than required to meet the INEEL's predetermined minimum distances, the circular capture zones were chosen to ensure that the wellhead protection area protects the EBR-I pubic water system. Since the wellhead protection area for EBR-I is circular, the boundary angles for EBR-I wellhead protection area are 0-360 degrees. The maximum distances between the well and the boundaries of the 3-year, 6-year, and 10-year capture zones are 150, 300 and $500 \mathrm{ft}$, respectively.

2.1.4.3.4 Gun Range Drinking Water Wellhead Protection Areas-Figure 2-20 shows the wellhead protection area and capture zones for the single well at the Gun Range. The original RESSQC capture zones were long and thin, which results from the relatively high transmissivity value assumed and the very low pumping rate reported. Because no site-specific transmissivity data were available for the Gun Range area, the widely quoted average INEEL value of 173,000 $\mathrm{ft}^{2} /$ day was used in running the RESSQC model. The flow direction of 220 degrees was measured from a site-scale map of water level contours (Pittman et al. 1988), though the flow direction might change when surface water flows in the Big Lost River. Therefore, the wellhead protection area boundary angles were widened to cover this uncertainty. The final wellhead boundary angles for the Gun Range area are $0-80$ degrees, and the 3-year capture zone extends 3,763 ft, the 6 -year capture zone extends 7,533 ft, and the 10-year capture zone extends $12,600 \mathrm{ft}$ from the wellheads.

\subsection{Idaho Nuclear Technology and Engineering Center Drinking Water} Wellhead Protection Areas-Figure 2-21 shows the wellhead protection area and capture zones for the two drinking water wells at INTEC, CPP-04, and CPP-05. The long, thin shape of the original RESSQC capture zones result from the relatively high transmissivity reported for wells in the area and assumed in running the RESSQC model. This also results from their relatively low average pumping rates. CPP-04 and CPP-05 are so close together that their capture zones overlap.

The INTEC drinking water wells are the closest wells to the Big Lost River, and river flow could be expected to cause changes in gradient and flow direction in the aquifer. However, given the geometry of the situation, such changes would not cause the INTEC capture zones to be displaced in a manner that would make the wells more vulnerable to contamination. Other things being equal, river flow should cause a more southeasterly flow. The equilibrium capture zones formed in response to this flow direction (assuming that relatively steady surface water flow conditions persisted long enough to allow establishment of equilibrium conditions) would have a northwesterly trend. If the infiltration rate from the river were high enough, a linear mounding of the water table could occur along the river's course, creating a groundwater divide, and the capture zones might even terminate there. 


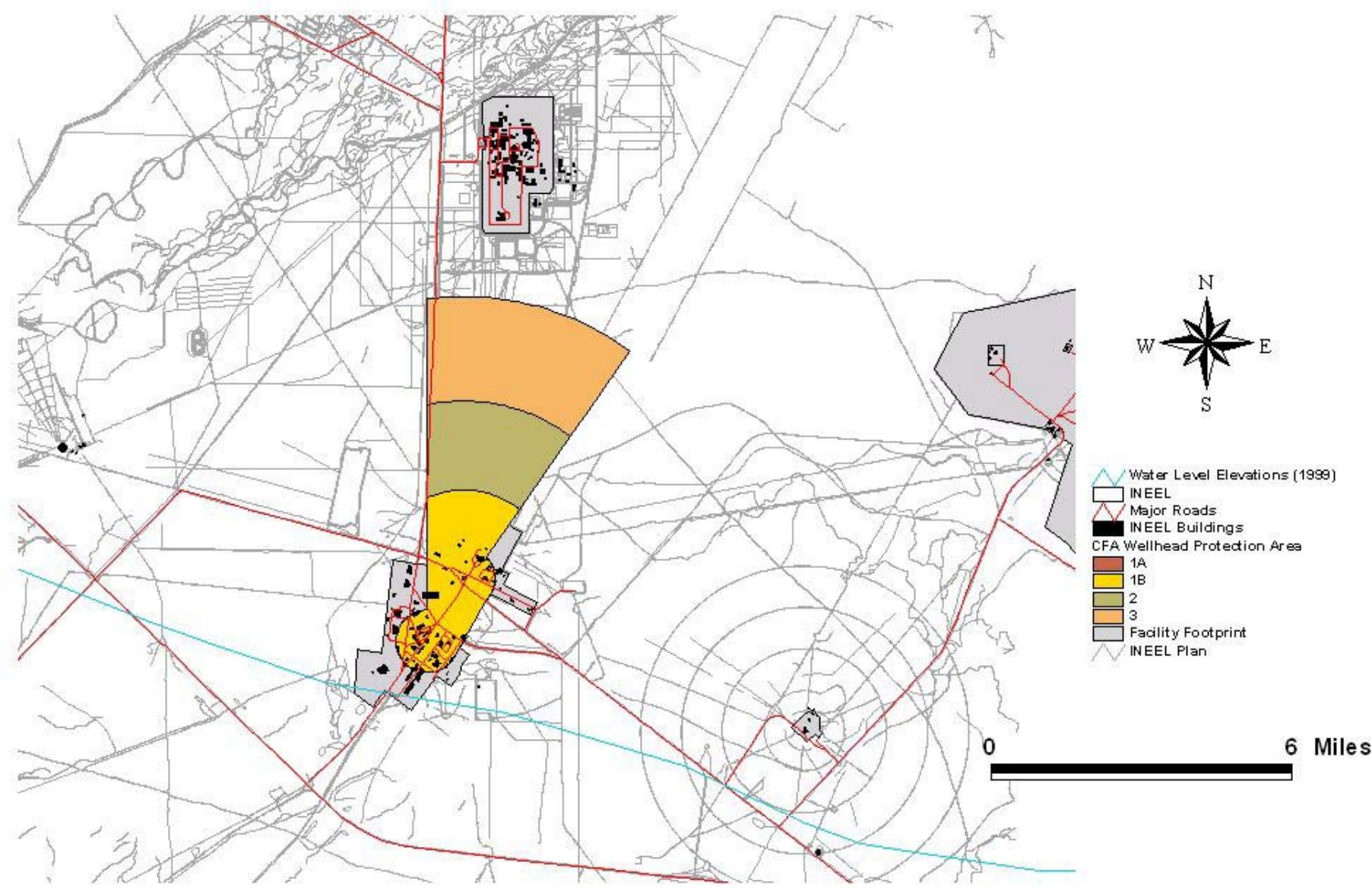

Figure 2-18. Central Facilities Area drinking water wellhead protection areas. 


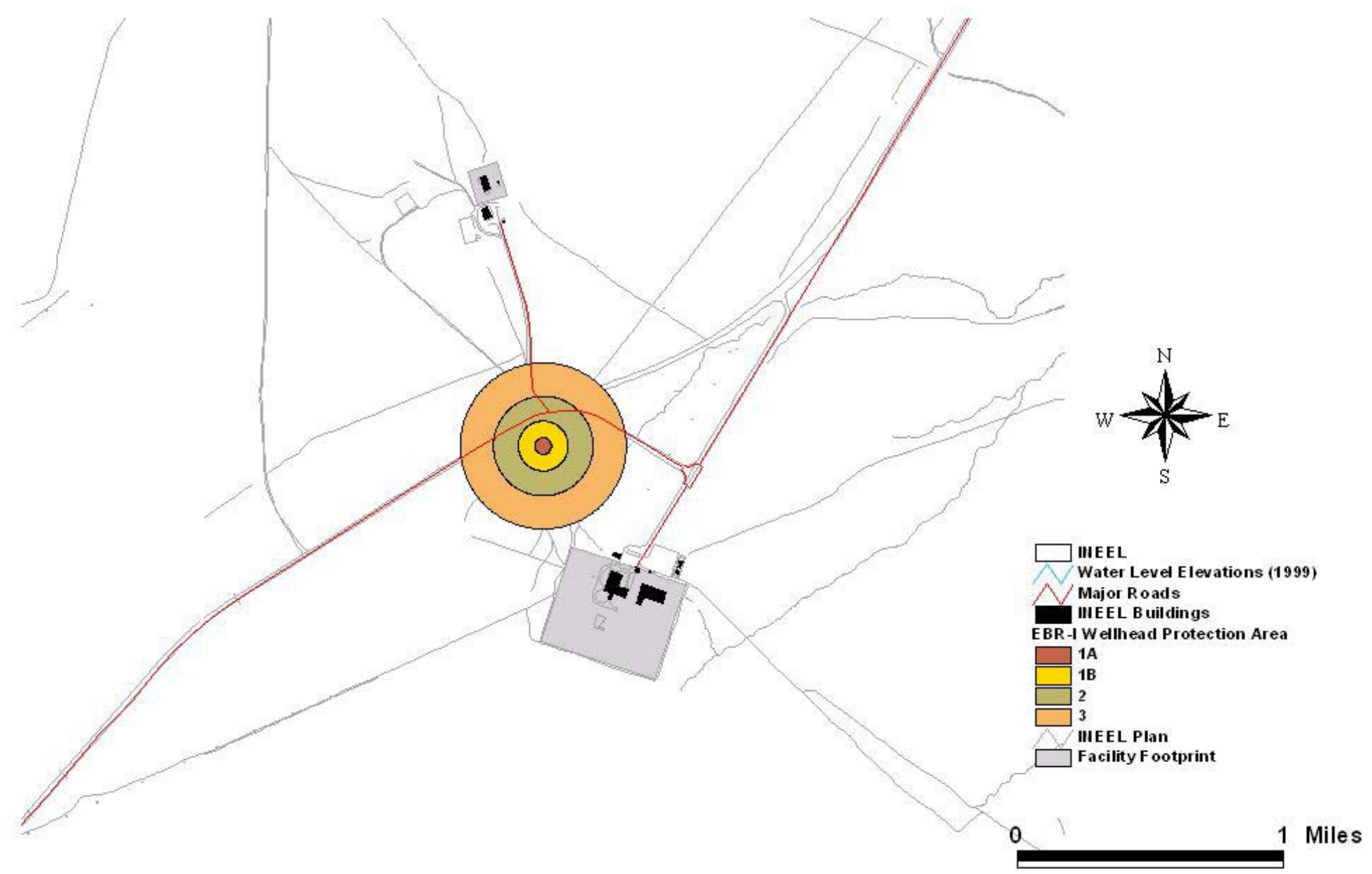

Figure 2-19. Experimental Breeder Reactor-I drinking water wellhead protection areas. 


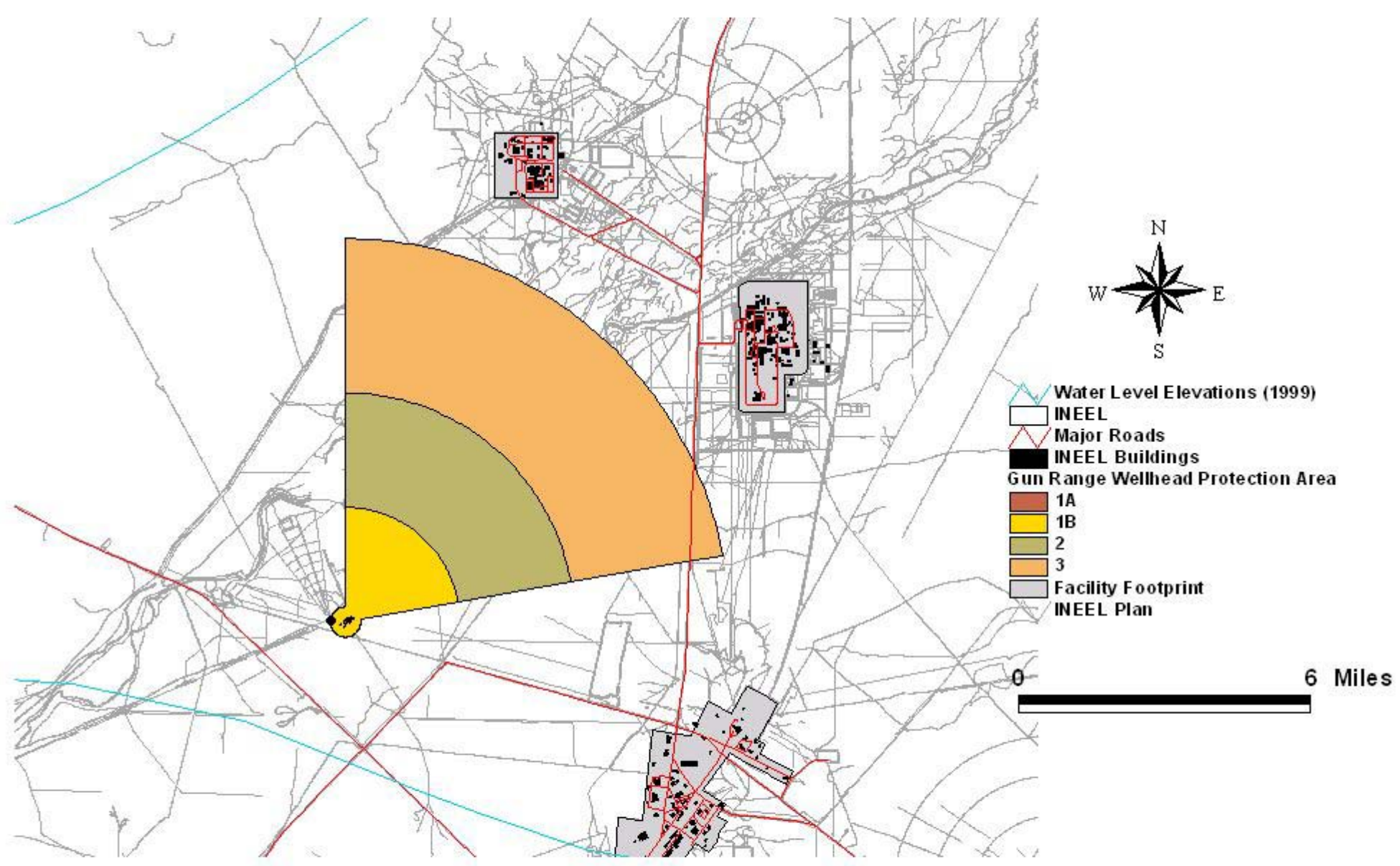

Figure 2-20. Gun Range drinking water wellhead protection areas. 


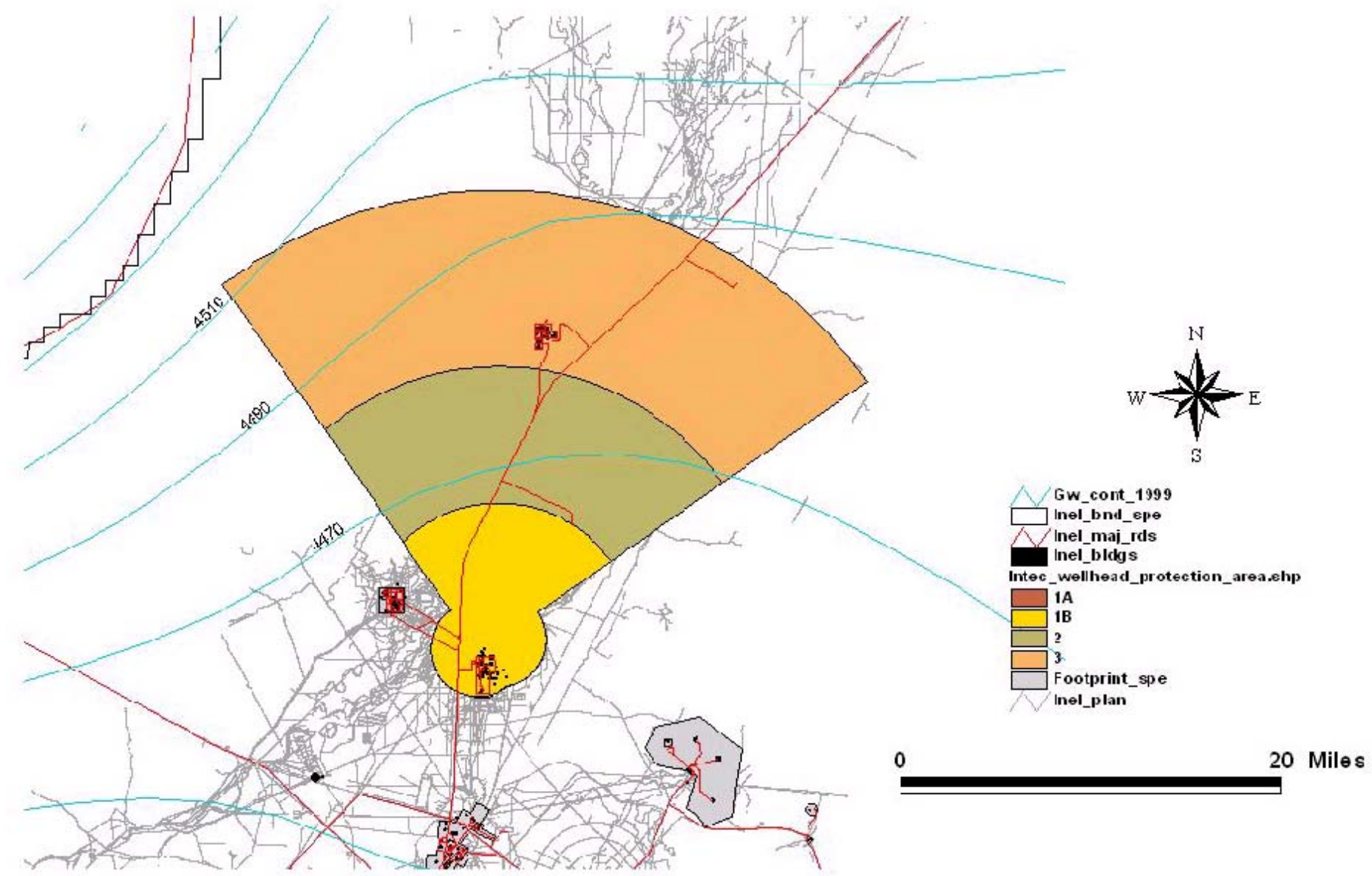

Figure 2-21. Idaho Nuclear Technology and Engineering Center drinking water wellhead protection areas. 
Reflecting the high degree of uncertainty associated with the wells located so close to the Big Lost River, the wellhead protection area boundary-angles for INTEC are 325-55 degrees. Also reflecting the river flows, the 3 -year capture zones of these wells extend approximately $11,533 \mathrm{ft}$; the 6 -year capture zones extend 23,067 ft; and the 10-year capture zones extend 38,000 ft northeast of INTEC.

\subsection{Main Gate Facility Drinking Water Wellhead Protection Areas-}

Figure 2-22 shows the wellhead protection area and capture zones for the Main Gate Facility well. Initially, wellhead protection area maps were not developed for this facility since they were not mandatory and it appeared to be rather obvious that no significant sources of contamination were present in this area. However, since such an evaluation is required under the Source Water Assessment Program, a wellhead protection area was developed for this area. Because of its relatively stable groundwater flow patterns and its relative isolation from other facilities, the calculated fixed-radius method was used to develop the capture zones. Based on DEQ's table for calculating fixed radii in eastern Snake River Plain basalt (Table 2-2), and knowing that the peak pumping capacity of the Main Gate Facility well is 20 gpm, the fixed radii for this facility are 50,2,700, 5,300 and 8,800 ft.

\subsection{Naval Reactors Facility Drinking Water Wellhead Protection Areas-} Figure 2-23 shows the wellhead protection area and capture zones for the two drinking water wells at NRF: wells NRF-2 and NRF-3. The long, thin shapes of the original RESSQC capture zones are a function of the relatively high transmissivity reported for wells in the area. The northerly orientation of the capture zones reflects the generally southward flow of the eastern Snake River Plain Aquifer. The boundary angles for the wellhead protection area are 330-30 degrees. The 3-year capture zones extend $6,700 \mathrm{ft}$, the 6 -year capture zones extend 13,400, and the 10-year capture zones extend 22,400 ft from the wellheads.

2.1.4.3.8 Power Burst Facility Drinking Water Wellhead Protection Areas-Figure 2-24 shows the wellhead protection area and capture zones for the two production wells in the $\mathrm{PBF} / \mathrm{SPERT}$ area. The capture zones are long and thin, indicating high transmissivity, but they are relatively short, indicating the relatively low pumping rate of the wells. The capture zones are orientated to the northeast, reflecting the generally southwest flow direction of the eastern Snake River Plain in this area. The boundary angles of the wellhead protection area are 25-55 degrees, indicating the relatively stable flow direction in this area. The maximum lengths of the 3-year capture zones are $1,087 \mathrm{ft}$, the 6-year capture zones are 2,173 ft, and the 10-year capture zones are 3,600 ft.

\subsection{Radioactive Waste Management Complex Drinking Water Wellhead}

Protection Areas-Figure 2-25 shows the wellhead protection area and capture zones for the RWMC Production Well. The transmissivity value for this well is low relative to other wells in the region. Therefore, a somewhat larger (but still low for the region) value was used in running the RESSQC model (Table 2-8), contributing to the development of relatively short, squat-shaped capture zones. However, there is still a concern that the transmissivity reported for the RWMC well is not representative of the average value for the area. In addition, as noted previously, local aquifer flow at RWMC is known to change directions greatly, or even reverse over time, in response to infiltration from surface water flow in the Big Lost River and RWMC spreading areas. For example, when flow direction changed in the mid-1980s, water in the aquifer beneath RWMC flowed for a period from west to east. Under such circumstances, the long axis of the capture zone would swing around to the west to align with the temporary new flow direction, in much the same way that a weather vane swings into the wind when the wind changes direction. Therefore, circular capture zones were developed to account for the high level of uncertainty in the local hydrologic conditions. 


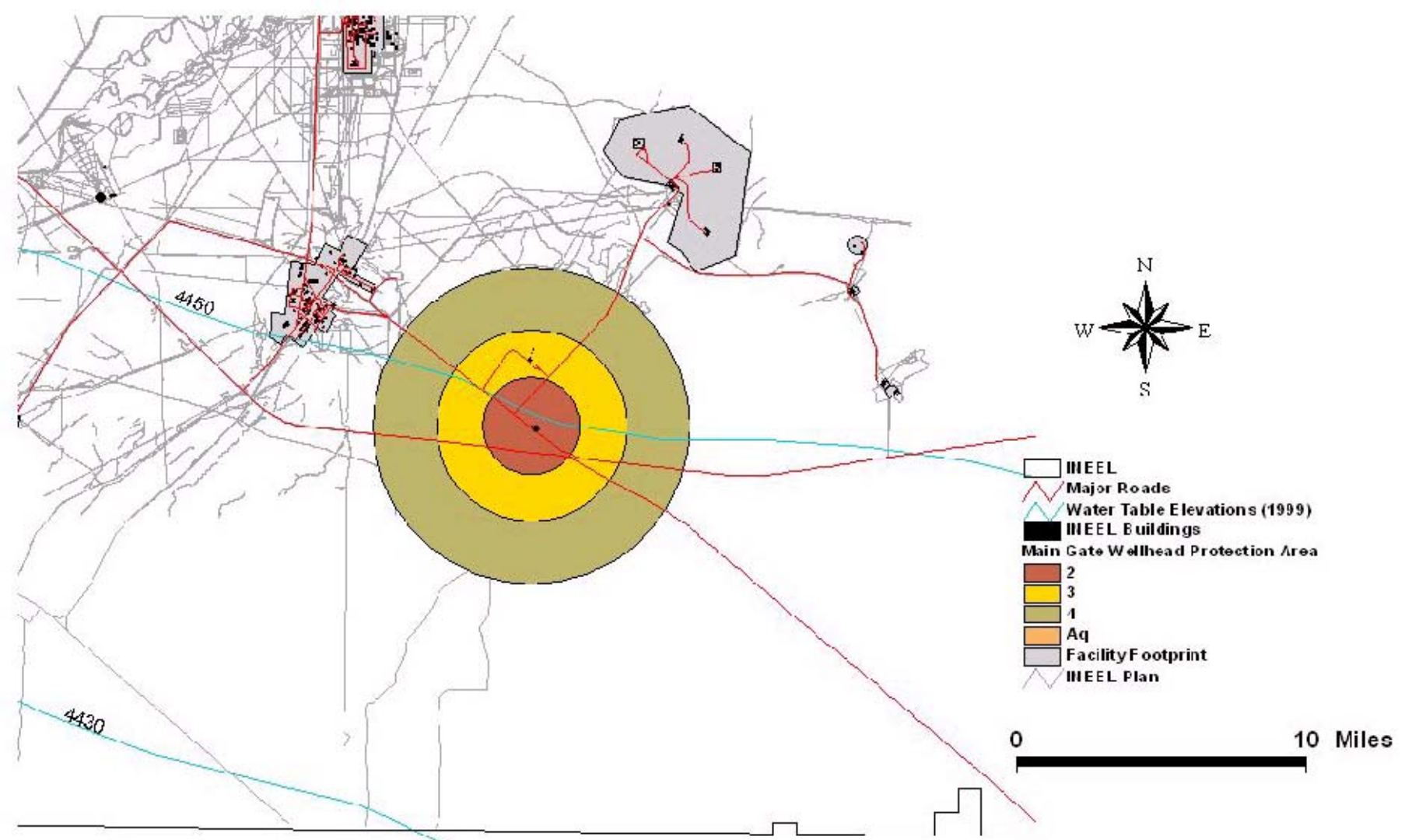

Figure 2-22. Main Gate drinking water wellhead protection areas. 


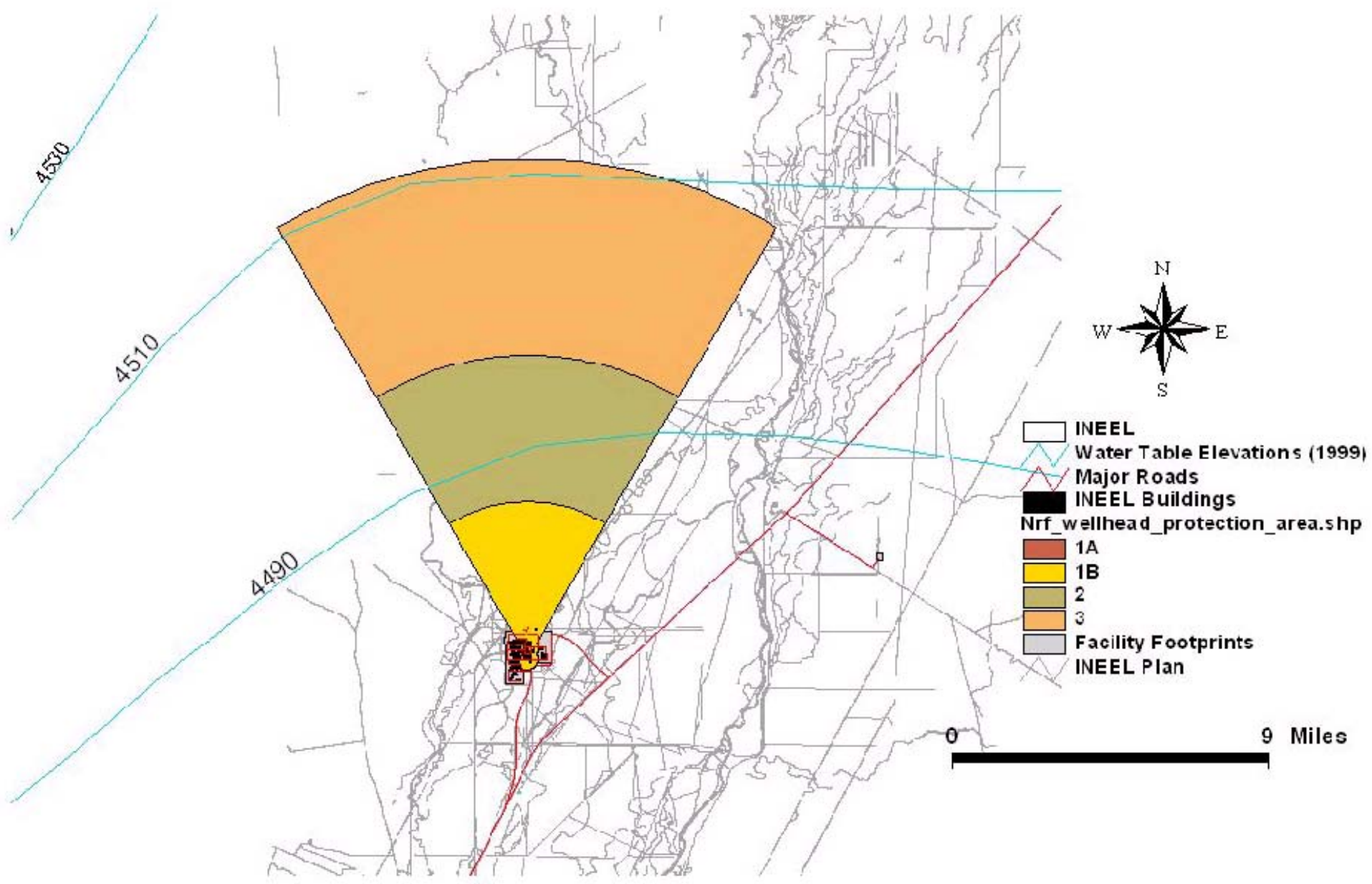

Figure 2-23. Naval Reactors Facility drinking water wellhead protection areas. 


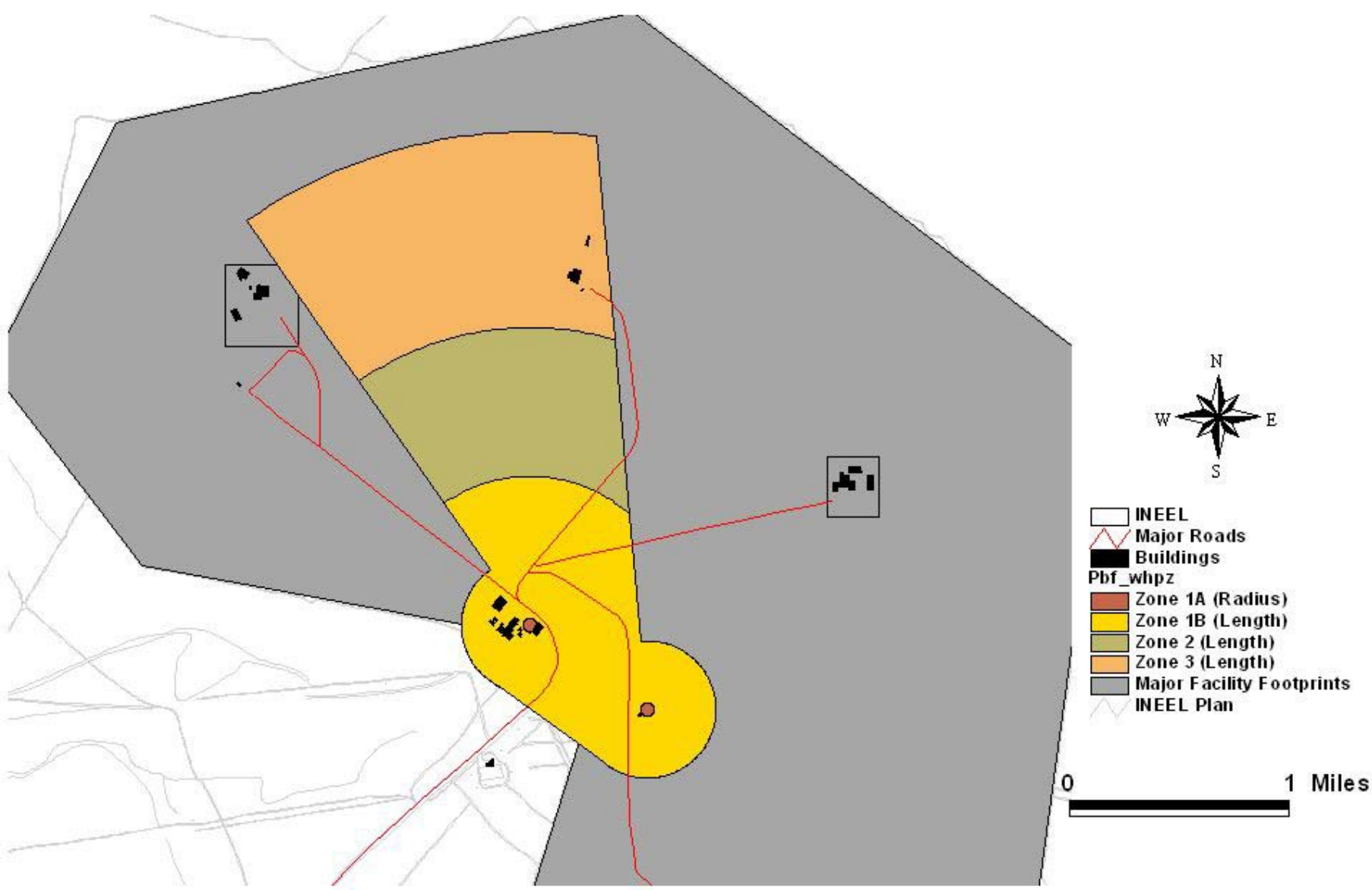

Figure 2-24. Power Burst Facility drinking water wellhead protection areas. 


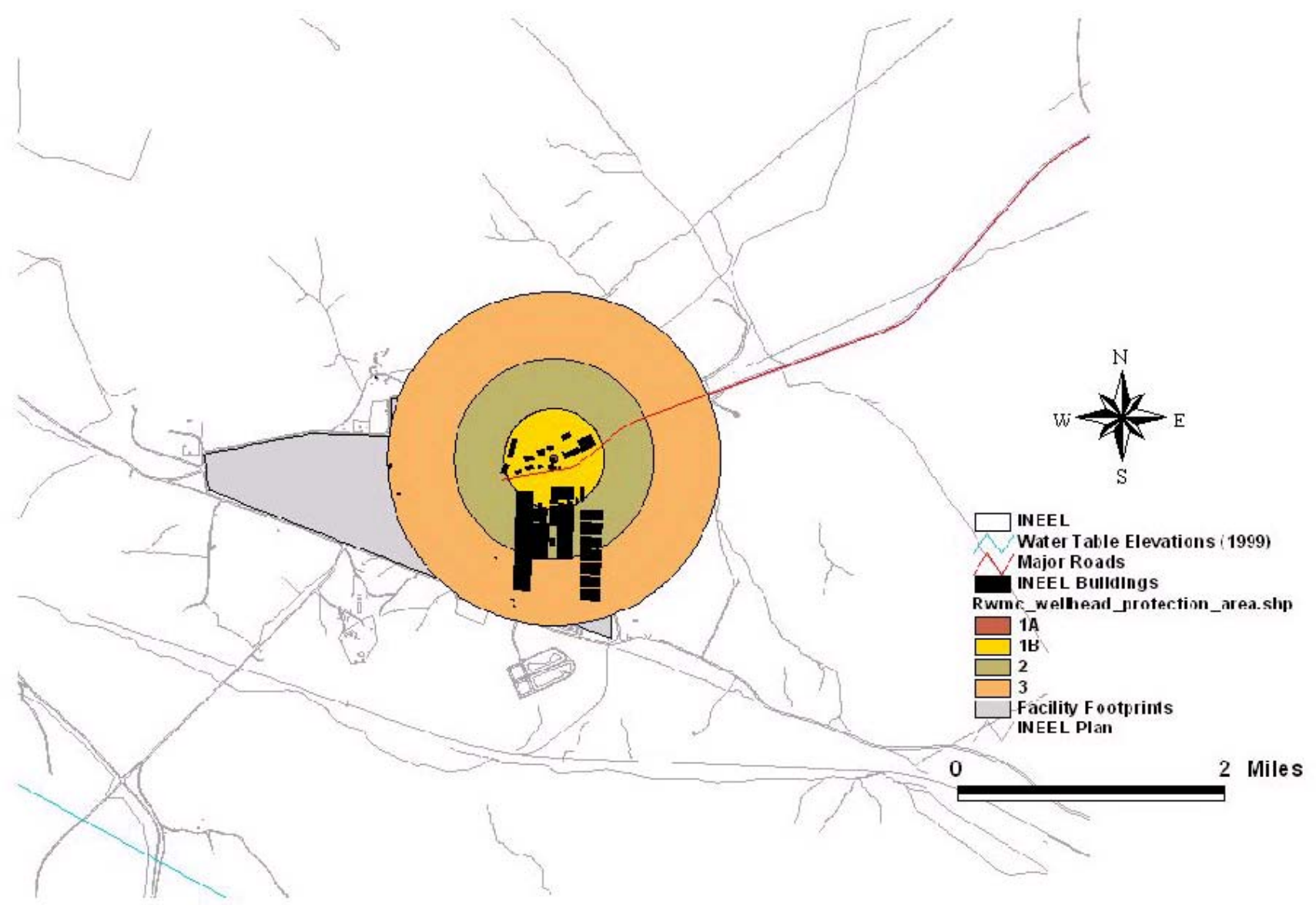

Figure 2-25. Radioactive Waste Management Complex drinking water wellhead protection areas. 
Since the wellhead protection area for the RWMC is circular, the boundary angles are 0-360 degrees. The maximum length of the 3-year capture zone extends $600 \mathrm{ft}$, the 6-year capture zone extends $1,200 \mathrm{ft}$, and the 10-year capture zone extends $2,000 \mathrm{ft}$ from the wellhead.

\subsection{Test Area North/Containment Test Facility Drinking Water Wellhead} Protection Areas-Figure 2-26 shows the wellhead protection area and capture zones for TAN/CTF. These wells are southeast of the TAN/CTF facility. The short, squat shape of their capture zones reflects the relatively low value assumed for transmissivity, along with relatively low pumping rates at TAN/CTF. The northeastern orientation of the capture zones indicates the generally southeastern flow direction of the eastern Snake River Plain Aquifer in this area. The wellhead protection area boundary angles for the TAN/CTF area are 355-55 degrees, reflecting the uncertainty about flow direction associated with the flat water table in this area. The 3-year capture zones extend $500 \mathrm{ft}$, the 6-year capture zones extend $800 \mathrm{ft}$, and the 10-year zones extend $1,200 \mathrm{ft}$ from the wellheads.

\subsection{Test Area North/Technical Support Facility Drinking Water Wellhead}

Protection Areas-Figure 2-26 shows the wellhead protection area and capture zones for the two TAN/TSF drinking water/production wells. These wells are located along the northeast margin of TAN/TSF. The short, squat shape of their capture zones reflects the relatively low value assumed for transmissivity (though slightly higher than TAN/CTF), along with relatively low pumping rates at TAN/TSF. The northern orientation of the capture zones indicates the generally southern flow of the eastern Snake River Plain Aquifer in this area. The boundary angles for the wellhead protection area are 315-25 degrees. The maximum length of the 3-year capture zones is $667 \mathrm{ft}$, the 6-year capture zones is $1,333 \mathrm{ft}$, and $\mathrm{t}$ the 10 -year zones is $2,000 \mathrm{ft}$ from the wellheads.

2.1.4.3.12 Test Reactor Area Drinking Water Wellhead Protection Areas-Figure 2-27 shows the wellhead protection area and capture zones for the Test Reactor Area (TRA). The wells are located at the northeast edge of the facility. The northeasterly orientation of the long axis of the capture zones reflects the southwesterly flow. The capture zones are relatively broad, which reflects the large volumes pumped from all three wells. The boundary angles for the TRA wellhead protection area are 30-60 degrees. The length of the 3-year capture zone is 3,067 ft, the 6-year capture zone is $6,133 \mathrm{ft}$, and the 10 -year capture zone is $9,200 \mathrm{ft}$ from the three TRA wellheads.

\subsubsection{Conjunctive Source Delineation}

It is well established that there is a strong hydrologic connection between the three streams that flow on or near the INEEL and the source of all drinking water at the INEEL - the eastern Snake River Plain Aquifer (Figure 2-28). The Big Lost River, Little Lost River, and Birch Creek are all "losing" streams. Water that flows from these tributaries onto the eastern Snake River Plain either infiltrates to the eastern Snake River Plain Aquifer or is "lost" to the atmosphere via evapotranspiration.

Although historically the Little Lost River flowed onto the INEEL, since irrigation began in that valley, no surface water has flowed across the INEEL's boundary. Therefore, the only water flowing from the Little Lost River basin to the INEEL is groundwater that will be monitored and evaluated as such.

Both the Big Lost River and Birch Creek flow onto the INEEL intermittently, and their areas of recharge could be their channels plus their flood plains/large areas where ponding occurs.

The facilities of interest for conjunctive management purposes are TAN and INTEC since they are adjacent to the Big Lost River and Birch Creek. However, their stream channels are high above the eastern Snake River Plain Aquifer (approximately $200 \mathrm{ft}$ to $500 \mathrm{ft}$ above the aquifer). Therefore, there is sufficient natural filtration by the soil column such that there is little chance of protozoan microorganisms 


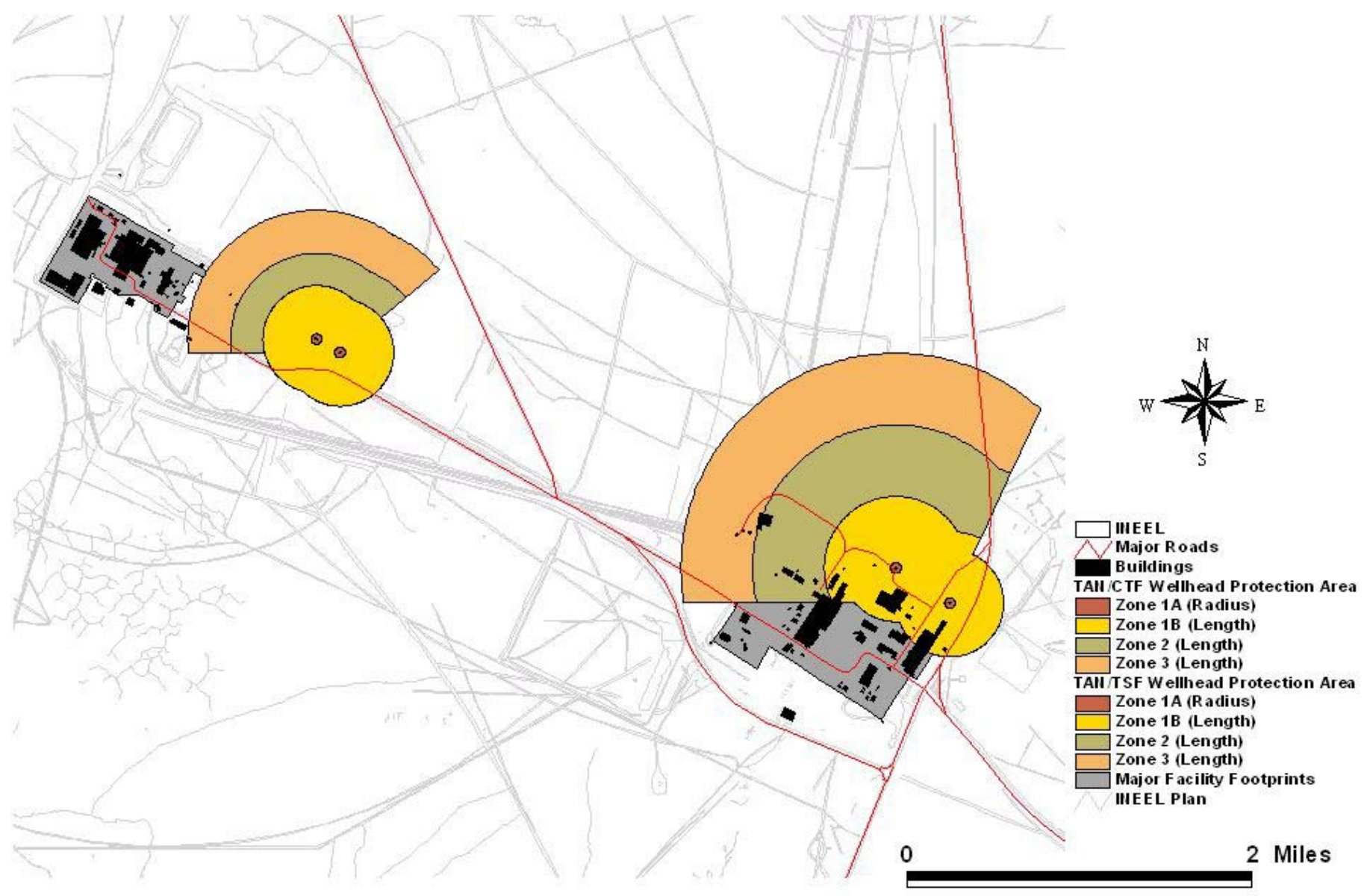

Figure 2-26. Test Area North/Containment Test Facility and Test Area North/Technical Support Facility drinking water wellhead protection areas. 


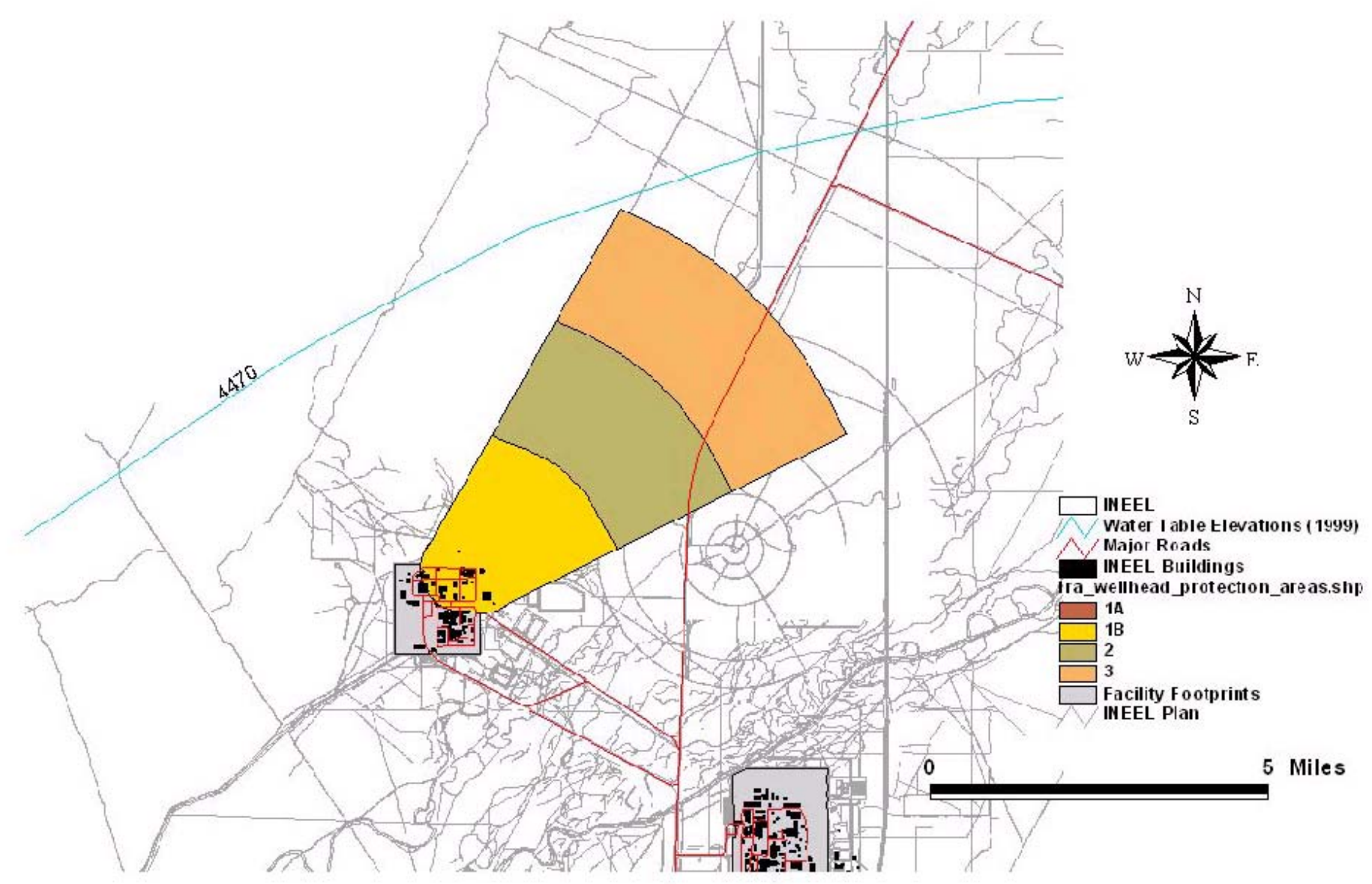

Figure 2-27. Test Reactor Area drinking water well protection areas. 


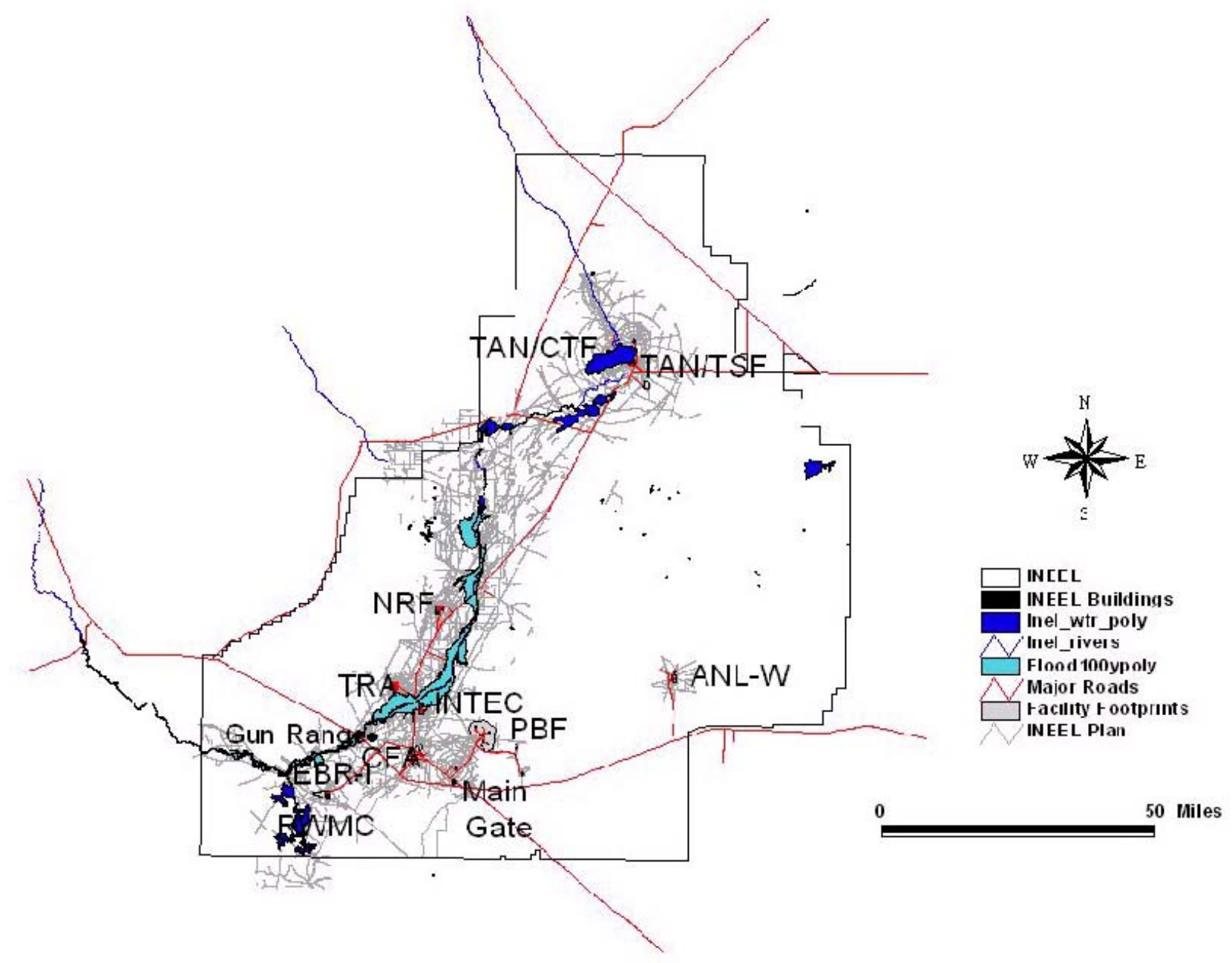

Figure 2-28. INEEL surface water/groundwater conjunctive areas. 
being transported from those channels to the INEEL's drinking water wells. Other factors that ensure that there is an insignificant risk of protozoan microorganisms being transported to INEEL water wells include:

- $\quad$ Each of the streams are relatively small and all are intermittent

- $\quad$ The thick vadose zone beneath the INEEL in most cases blocks or filters contaminants before reaching given well intakes

- $\quad$ The INEEL's rigorous historical sampling does not indicate that there have been any significant sources of microbial contamination in any of the drinking water wells.

One concern is the potential of floodwaters over topping their banks and flowing into facilities, causing contaminants to migrate to the eastern Snake River Plain Aquifer. Considering a 100-year flood or less, the only potential areas of concern are INTEC, TAN/CTF and TAN/TSF. A 100-year Big Lost River flood event at INTEC may mobilize soil contaminants. TAN/CTF and TAN/TSF are not likely to cause a contaminant migration issue for a 100-year or less flooding event, unless the flows continue long enough to fill the Big Lost River and/or Birch Creek Playas, which is highly unlikely. The INEEL is actively researching these issues as part of its ongoing floodplain analyses and CERCLA remedial investigations. The results of this research will be incorporated into the appropriate management plans.

\subsection{Contaminant Sources Identification and Inventory}

The potential risk from a given contaminant or pollutant depends on several factors including: the toxicity and mobility of the contaminant; the distance between the source and receptor; and amount of dilution, local geology and hydrology; and other factors. Reviewing EPA's general list of potential sources of groundwater contamination (Table 2-10), it is clear that there are some potential sources of groundwater contamination both on the INEEL and in the surrounding areas. For the most part, the activities conducted around the INEEL may pose some potential risk to the INEEL's public drinking water supplies. However, because of the nature of the INEEL's mission and its configuration, the INEEL itself has the highest potential for negatively impacting its drinking water supplies.

\subsubsection{Potential Off-Site Contaminant Sources}

The areas surrounding the INEEL are primarily native sagebrush steppe lands or lands managed for agricultural purposes, and the size and number of municipalities and the level of industrial or other commercial development near the INEEL are limited (Figure 2-29). Much of the land around the INEEL, especially to the north, south and west, is government owned and controlled. The U.S. Forest Service owns almost all of the mountainous lands in the tributary basins that contribute source water to the INEEL. The valley floor is a mix of public (primarily U.S. Bureau of Land Management) and private land. Uses of the state and federal public lands in the tributary basins are primarily limited to logging, grazing, and recreation.

Private ownership in the tributary basins is typically concentrated along the valley floors in areas conducive to irrigated agriculture. Some of the agricultural lands are fairly high in these basins; however, they are used for cattle grazing or growing local hay. In these areas, it is likely that there would be a very limited use of pesticides, herbicides, or fertilizers that may contaminate soil or water. In general, pollutants in these areas are limited to grazing impacts (e.g., erosion, riparian habitat modification, 
Table 2-10. Summary of potential sources of groundwater contamination (DEQ 1997).

- EPA Class I Sources-Designed to discharge substances

- $\quad$ Injection Wells

- $\quad$ Land Application Facilities

- $\quad$ Non-Waste Facilities

- $\quad$ Subsurface Percolation

- EPA Class II Sources-Designed to treat/store/dispose of substances (planned/unplanned)

- $\quad$ Above Ground Storage Tanks

- Animal Burial

- Containers

- $\quad$ Munitions Detonation Sites

- Graveyards

- Landfills

- $\quad$ Materials stockpiles

- $\quad$ Open Dumps

- $\quad$ Open Burning Sites

- $\quad$ Radioactive Disposal

- Residential Disposal

- $\quad$ Surface Impoundment's

- $\quad$ Underground Storage Tanks

- Waste Tailings

- Waste Piles

- $\quad$ EPA Class III Sources-Designed to retain substances during transport or transmission

- $\quad$ Materials Transport/Transfer

- $\quad$ Pipelines

- $\quad$ EPA Class IV Sources-Discharges substances as a consequence of other planned activities

- $\quad$ Animal Feeding Operations

- De-icing Activities

- $\quad$ Irrigation Practices

- $\quad$ Mining

- $\quad$ Atmospheric Pollutants

- $\quad$ Pesticides and Fertilizer

- $\quad$ Urban Runoff

- $\quad$ EPA Class V Sources-Sources providing a conduit or induces discharge through altered flow patterns

- $\quad$ Construction Excavation

- $\quad$ Non-Waste Wells/Borings

- $\quad$ Production Wells

- Water Supply Wells

Utility Corridors

- $\quad$ EPA Class VI Sources-Naturally occurring sources whose discharge is created and/or exacerbated by human activity

- $\quad$ Gravel Mining Operations

- Groundwater/Surface Water Interactions

- $\quad$ High Total Dissolved Solids/Salt water Intrusion

- $\quad$ Natural Leaching 


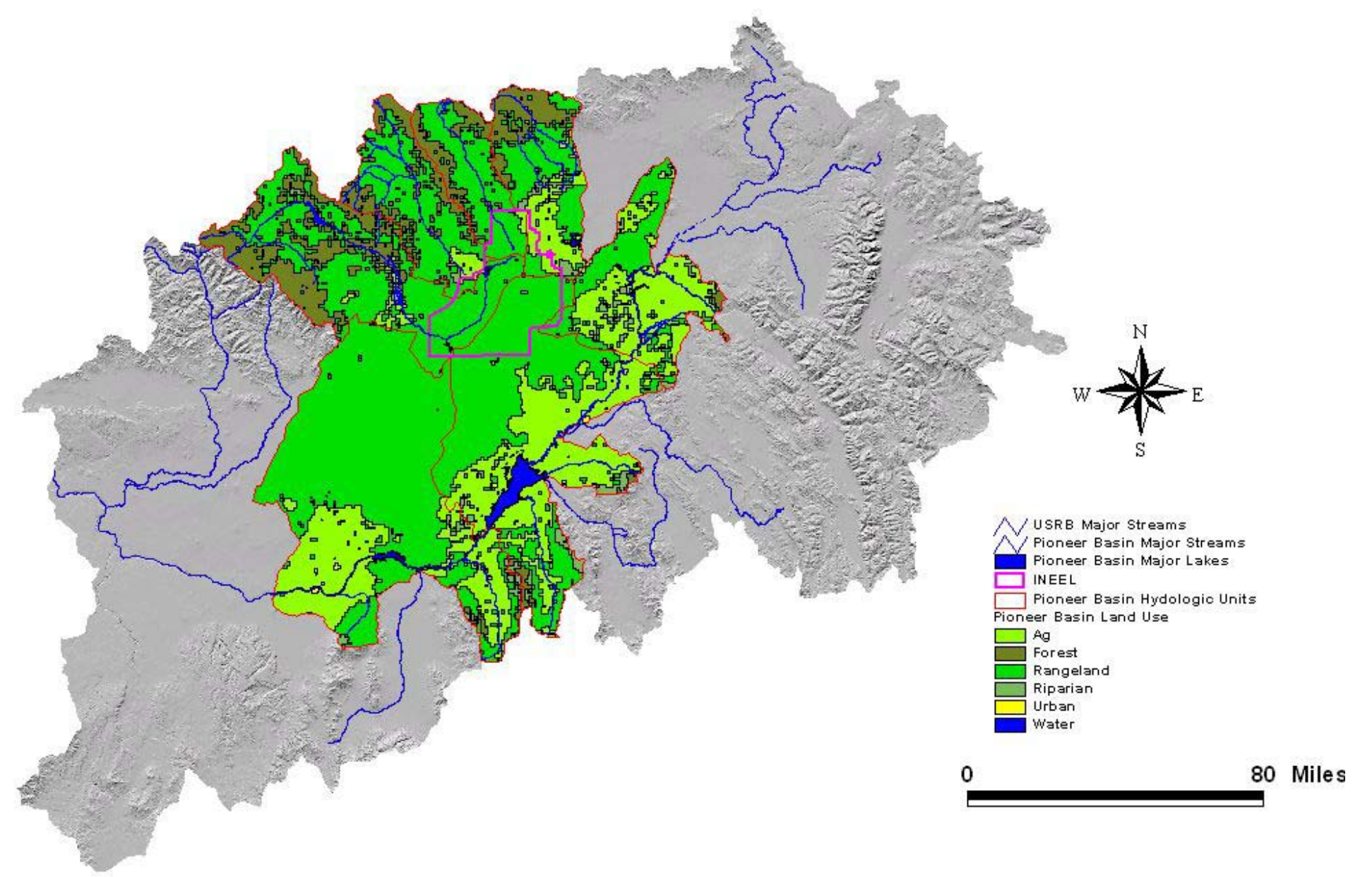

Figure 2-29. Development and land use near the Idaho National Engineering and Environmental Laboratory. 
nutrients, and bacterial contamination). In addition, there is stream flow modification due to irrigation diversions. This is reflected in the Clean Water Act (CWA) 303(d) listings for the tributaries (Table 2-11). Further downstream near the mouths of these valleys and on the eastern Snake River Plain, irrigated agriculture tends to be higher concentrated. This is primarily due to richer soils, longer growing seasons, and the increased availability of water. Due to climate limitations, crops in the tributaries tend to be irrigated pasture, hay, and small grains. Therefore, chemical use is lower, hence, a very limited likelihood of groundwater contamination from those uses.

On privately owned lands east of the INEEL, there is a mix of ranches, dry land farms, and irrigated farms. However, a much larger percentage of these are farms that grow row crops such as potatoes. Hence, in general, there is a greater likelihood of pesticide and herbicide use. Although it is probably a relatively low risk, irrigated agriculture northeast of the INEEL may threaten water quality in the INEEL's public water systems. For example, irrigation is accompanied by a high level of evaporation, resulting in infiltration to the aquifer of water enriched in any dissolved constituents it already carried. Infiltrating irrigation water may also carry elevated levels of constituents such as sodium, which are especially easily leached from the soil. Relatively high levels of nitrate downgradient from the Mud Lake area can be linked to fertilizer use. Finally, Mud Lake is hydrologically upgradient of the INEEL; therefore, if contaminants migrate to the eastern Snake River Plain Aquifer, they may flow to several INEEL facilities such as the INTEC, TRA, and CFA.

Land management practices southeast of the INEEL pose little threat to the INEEL because those lands are almost exclusively dry land pasture or are sprinkler irrigated using groundwater, so less water is used, hence a lower amount of potential contaminants migrates to the groundwater. In addition, little irrigated agriculture is actually practiced near the INEEL's southeastern boarder, and contaminants from those areas are typically not on a groundwater flow path with INEEL facilities.

2.2.1.1 Big Lost River. The Big Lost River provides approximately $10 \%$ of the tributary flows to the Snake River Plain above King Hill, and it is the largest supply of surface water to the INEEL. Of the tributary basins that contribute source water to the INEEL, the Big Lost River Valley clearly has the highest potential for contaminating an INEEL public water system. This is because this valley is the most developed of the four tributary basins. In addition, the Big Lost River has the largest and most consistent flow of any surface water on the INEEL, and it flows near most of the INEEL major facilities. However, since the Big Lost River Aquifer flows south/southwest from the Arco area rather than toward the INEEL, groundwater quality in the Big Lost River Basin is not a concern relative to the INEEL's Drinking Water Systems.

Most of the land in this watershed is publicly owned except a sizable corridor from Chilly to Mackay and then to Arco and a small strip of private land along Antelope Creek. Most of the private land is dry land pasture or irrigated pastureland. Less than a dozen small municipalities are in the Big Lost River drainage, but all are next to the Big Lost River. Arco and Mackay are the two largest, with 1990 populations of 1,016 and 574 respectively. Finally, there are few industrial or manufacturing processes in the basin that could contribute significant quantities of pollutants to the environment.

Based on the information on EPA's Surf Your Watershed (EPA 2002), only a few facilities in this basin manage significant quantities of contaminants of concern. The only toxic release inventory facility in this basin is the INEEL. Only two hazardous waste facilities are in this basin, Double J Electric and the U.S. Forest Service office, both in Mackay. No CERCLA sites are listed in this basin. However, the INEEL, located in the lower portions of the Big Lost River Basin, is a RCRA-permitted facility and the entire INEEL is listed as a superfund (CERCLA) site. The only National Pollutant Discharge Elimination System (NPDES) permits listed for the Big Lost River are for a trout hatchery and a sewage treatment 
Table 2-11. Clean Water Act 303(d) listed streams tributary to the INEEL.

BIG LOST RIVER (17040218)

\begin{tabular}{|c|c|c|}
\hline Reach ID & Water Body Name & Parameter of Concern \\
\hline ID2161-1998 & Big Lost River & $\begin{array}{l}\text { Dissolved oxygen, flow alteration, nutrients, sediment, } \\
\text { temperature }\end{array}$ \\
\hline ID2164-1998 & Big Lost River & Nutrients, sediment \\
\hline ID2167-1998 & Spring Creek & $\begin{array}{l}\text { Temperature, dissolved oxygen, flow alteration, nutrients, } \\
\text { sediment }\end{array}$ \\
\hline ID2168-1998 & Antelope Creek & Flow alteration, sediment, temperature \\
\hline ID2176-1998 & Twin Bridges Creek & Nutrients, sediment \\
\hline ID2179-1998 & East Fork Big Lost River & Habitat alterations \\
\hline ID2180-1998 & East Fork Big Lost River & Sediment, temperature \\
\hline ID5236-1998 & Little Boone Creek & Unknown \\
\hline ID5237-1998 & Warm Springs Creek & Unknown \\
\hline ID5295-1998 & East Fork Wood River & Unknown \\
\hline ID5650-1998 & Fish Creek & $\begin{array}{l}\text { Bacteria, dissolved oxygen, flow alteration, nutrients, } \\
\text { sediment }\end{array}$ \\
\hline ID7009-1998 & Road Creek & Unknown \\
\hline \multicolumn{3}{|c|}{ BIRCH CREEK (17040216) } \\
\hline Reach ID & Water Body Name & Parameter of Concern \\
\hline ID2154-1998 & Birch Creek & Flow alteration, habitat alterations, nutrients, sediment \\
\hline \multicolumn{3}{|c|}{ LITTLE LOST RIVER (17040217) } \\
\hline Reach ID & Water Body Name & Parameter of Concern \\
\hline ID2145-1998 & Wet Creek & Flow alteration, sediment, temperature \\
\hline ID2148-1998 & Sawmill Creek & Sediment, temperature \\
\hline ID5656-1998 & Little Lost River & Temperature, unknown \\
\hline ID5660-1998 & Little Lost River & Unknown \\
\hline \multicolumn{3}{|c|}{ MEDICINE LODGE (17040215) } \\
\hline Reach ID & Water Body Name & Parameter of Concern \\
\hline ID2206-1998 & Medicine Lodge Creek & Flow alteration, sediment, temperature \\
\hline ID2210-1998 & Edie Creek & Habitat alterations, nutrients, sediment \\
\hline ID2211-1998 & Irving Creek & Habitat alterations, nutrients, sediment \\
\hline ID2212-1998 & Fritz Creek & Nutrients, temperature \\
\hline ID2215-1998 & Warm Springs Creek & Nutrients, sediment \\
\hline
\end{tabular}


plant in Mackay, Idaho. Based on the above information and several visits to the valley, no facilities, processes or activities in the Big Lost River Valley upgradient of the INEEL appear to have the potential to cause significant water pollution to be of risk to the INEEL.

Although no water quality threats appear to be of consequence to the INEEL, EPA's Surf Your Watershed does show some water quality problems in the Big Lost River Valley associated with meeting established beneficial use criteria. Twelve reaches are listed on the basin's CWA 303(d) list (Table 2-11). However, the valley was listed as having a relatively low vulnerability to pollutants. Based on a review of the available information and several visits to the valley to evaluate the river corridor and potential contaminant sources, it is unlikely that any contaminants of concern in this tributary valley would be present in large quantities to affect any of the INEEL's public water systems along the Big Lost River corridor.

2.2.1.2 Little Lost River. The Little Lost River supplies a relatively small quantity of groundwater and no surface water to the INEEL. However, water from the Little Lost River Valley Aquifer does flow into the eastern Snake River Plain Aquifer near or possibly on the INEEL.

Most of the land in this watershed is publicly owned except a couple of small areas of private land north of Clyde, several corridors of private land from Clyde toward Howe, and a fairly large area of private land around Howe. Most of this land is dry land farms and ranches or irrigated pastureland. Four small municipalities are in the Little Lost River drainage, and each of them is adjacent to the Little Lost River. Howe is the largest municipality in the basin, with a 1990 population of 25 . The populations of the other towns are one to a few people each. Finally, few industrial or manufacturing processes in the basin could contribute some quantity of pollutants to the environment.

Based on the information on EPA's Surf Your Watershed (EPA 2002), only a few facilities in this basin manage significant quantities of contaminants of concern. The only toxic release inventory facility in this basin is the INEEL. Only four hazardous waste facilities are in this basin: the North Creek Mill, about 10 miles north of Howe; two U.S. Bureau of Land Management facilities; the Howe Airport; and the Antelope Creek Dump site. Finally, no CERCLA sites or NPDES-permitted facilities are listed for the Little Lost River Basin. No facilities, processes, or activities in the Lost River Valley upstream of the INEEL appear to have the potential to cause significant water pollution to be of risk to the INEEL's public water systems.

Although no water quality threats appear to be of consequence to the INEEL, EPA's Surf Your Watershed does show some water quality problems in the Little Lost River Valley associated with meeting established beneficial use criteria. Four stream reaches are listed on the basins 303(d) list (Table 2-11). The pollutants listed (e.g., temperature and sediments) have no impact on the INEEL's drinking water supplies. The valley is listed as having a relatively low vulnerability to other pollutants.

Based on a review of the available information and several visits to the valley to evaluate the river corridor and potential contaminant sources, it appears that there is almost no potential for any off-site contaminants of concern in large enough quantities to affect the INEEL's public water systems. In addition, since the Little Lost River does not flow onto the INEEL and no public water systems are located in this watershed, there is very little potential for surface water to transport contaminants from an accident in sufficient quantity to impact an INEEL's public water systems.

2.2.1.3 Birch Creek. The Birch Creek Basin provides a relatively small quantity of both surface water and groundwater to the INEEL. The only INEEL public water systems in this basin that could potentially be impacted by off-site flows from Birch Creek or the Birch Creek Valley Aquifer are TAN/CTF and TAN/TSF, since both are at the terminus of Birch Creek. However, most of the land in this 
watershed is publicly owned except a couple of small areas of private land north of Nicholia, and a small corridor of private land from Nicholia to just south of Blue Dome. Most of this land consists of dry land farms and ranches or irrigated pastureland. Nicholia and Blue Dome are the only municipalities in the Birch Creek Basin. Blue Dome is next to the Birch Creek. The 1990 population of each is one person. Finally, no industrial or manufacturing processes in the basin could contribute significant quantities of pollutants to the environment.

Based on the information on EPA's Surf Your Watershed (EPA 2000), no facilities in this basin manage significant quantities of contaminants of concern. No Toxic Release Inventory, RCRA hazardous waste, NPDES-permitted facilities, or CERCLA sites are in the Birch Creek Basin upgradient of the INEEL. Therefore, no facilities, processes, or activities in the Birch Creek Basin appear to have the potential to cause significant water pollution to be of risk to the INEEL.

Although no water quality threats appear to be of consequence to the INEEL, EPA's Surf Your Watershed does show some water quality problems in the Birch Creek Basin associated with meeting established beneficial use criteria. Several reaches in the Birch Creek Watershed are listed on the basins 303(d) list (Table 2-11). However, the pollutants listed (e.g., nutrients and sediments) should not impact the INEEL's drinking water supplies. This basin is listed as having a relatively low vulnerability to other pollutants.

Based on a review of the available information and several visits to the valley to evaluate the river corridor and potential contaminant sources, contaminants of concern would not likely be present in this valley in large enough quantities to affect the INEEL's public water systems. This is because this valley has such a small amount of development and it provides such a small amount of surface water and groundwater to the INEEL. However, based on an evaluation of the stream buffer corridor, flow conditions, and the configuration of the INEEL's systems, given the right flow conditions, a vehicle accident (e.g., a truck accident on Highway 28 or 22 near the Little Lost River) could possibly contaminate TAN's public water systems. However, because of the distance from the highway, the flow conditions, and stream flow is typically diverted to the east of the facility, the probability of this occurring is likely very low.

2.2.1.4 Medicine Lodge. The Medicine Lodge Basin provides no surface water to the INEEL, but contributes a significant amount of groundwater to the INEEL via the eastern Snake River Plain Aquifer. Of the northern tributary basins that recharge the INEEL, the Medicine Lodge Basin has the largest amount of privately owned land. Most land in the northern, upland portion of this basin is a mixture of federal and state public land. However, along the western and southern portions of this basin a large crescent-shaped area of privately owned land surrounds Mud Lake and the wildlife preserve north of Mud Lake. Most of this land is irrigated cropland.

Five municipalities are in the Medicine Lodge Basin; the largest two are Mud Lake and Terreton with 1990 populations of 179 and 40, respectively. However, no industrial or manufacturing processes in this basin could contribute significant quantities of pollutants to the environment.

Based on the information on EPA's Surf Your Watershed (EPA 2002), no facilities in this basin manage significant quantities of contaminants of concern. No Toxic Release Inventory, CERCLA, or NPDES-permitted facilities are in the Medicine Lodge Basin. However, four RCRA hazardous waste sites are in this basin: the BLM Monteview Soil Site, BLM Mud Lake Airport, Utah Power and Light Site, and the Mud Lake Farm Supply, Inc. However, these facilities appear to be relatively small and have little potential to significantly pollute the groundwater within the basin. Therefore, no facilities, processes, or activities in the Birch Creek Basin appear to have the potential to cause significant water pollution to be of risk to the INEEL. 
Although no water quality threats appear to be of consequence to the INEEL, EPA's Surf Your Watershed shows some water quality problems in the Medicine Lodge Basin associated with meeting established beneficial use criteria. These issues are identical to those in the Birch Creek and Little Lost River basins. Five reaches are listed on the basin's 303(d) list (Table 2-11). The pollutants listed (e.g., temperature, nutrients, and sediments) have no impact on the INEEL's drinking water supplies. This basin is listed as having a relatively low vulnerability to other pollutants.

Because of the location of this basin (northeast of the INEEL) and the predominant flow direction of the eastern Snake River Plain Aquifer (south/southwest), groundwater from this basin potentially may impact INEEL public water systems. However, based on a review of the available information and several visits to the valley to evaluate the river corridor and potential contaminant sources, contaminants of concern would not likely be present in this valley in large enough quantities to affect the INEEL's public water systems. This is because very little development is in this watershed and no surface water flows from this watershed onto the INEEL. Groundwater contaminants from this basin potentially may flow to the INEEL and impact some INEEL facilities (e.g., INTEC). However, that appears to be highly unlikely because of the small quantities of potential contaminants. In addition, since the Medicine Lodge Watershed does not flow onto the INEEL and no INEEL public water systems are located in this watershed, no surface water-transported contaminant from an accident could impact an INEEL's public water systems.

\subsubsection{Potential INEEL Facility Contaminant Sources}

The vast majority of the INEEL is native sagebrush steppe habitat that has experienced little disruption from human activities with the exception of some grazing along the periphery of the INEEL. However, within the various developed facilities/areas, human impacts range from nearly unnoticeable to very extensive. Most potential contaminant sources at the INEEL exist or originated within these facility/area boundaries. In fact, INEEL activities have included most of the categories of potential sources of contamination outlined by EPA in Table 2-10.

Based on its mission, the INEEL treats, stores, and disposes of large quantities of both chemical and radiological materials. During its 50 or so years of operation, the INEEL has intentionally disposed of and in some cases accidentally released contaminants into the environment. These included:

- $\quad$ Release of gasses to the atmosphere via stacks

- Discharge of wastewater to various cribs, ponds, ditches, and the ground surface

- Discharges of wastewater to the vadose zone or directly into the eastern Snake River Plain Aquifer

- Use of the INEEL as a bombing/artillery range.

Once released or discharged, these potential contaminants can either become "locked up" by environmental media (e.g., contaminants bind to particles in the soil column), or disperse and migrate through the environment via the atmospheric, hydrologic, soil column, or biotic pathways. In addition, in some areas, significant construction and earth moving activities have likely modified the environment, potentially concentrating or releasing natural constituents from the soil, modifying the temperature and sediment loads of the streams on-site. These activities may increase the mobility of potential contaminants of concern by removing protective soil covers and by concentrating areas of water seepage, infiltration, or injection. Many of these past and in a few cases, recent discharges, releases, or disturbances could potentially impact the INEEL's drinking water systems. 
2.2.2.1 Known/Potential Non-Point Sources of Contamination. Most non-point potential contaminant sources at the INEEL are caused by soil disturbances during construction or maintenance activities or past releases or discharges of potential contaminants into the atmosphere. Although soil disturbances can negatively impact surface water quality at the INEEL, because of the thick vadose zone, these activities will not likely affect groundwater quality. The possible exception is if these activities are located near one of the INEEL's deep flood control injection wells, in which case sediments, dissolved solids, and other naturally occurring materials can become entrained in storm water flows and injected to the eastern Snake River Plain Aquifer. Atmospheric releases, though not common, may be more problematic in that the materials released can be deposited into wide areas, including either directly onto local water bodies or on the soil surface. Where sufficient water is present to move those contaminants, they can potentially migrate though the soil column or via one of the INEEL's storm water injection wells and into the eastern Snake River Plain Aquifer.

The INEEL's Storm Water Pollution Prevention Program controls non-point potential contaminant sources caused by large-scale earth moving, large-scale removal of vegetation via natural (e.g., fires), or anthropogenic activities. This program regulates and enforces protective or restorative measures to prevent water pollution.

In the past 5 or so years, the INEEL range fires have burned approximately 120,000 acres of land. While fires are a natural feature of a sagebrush ecosystem, the loss of vegetation increases erosion and may mobilize chemical and/or radiological contaminants that had previously been released or discharged to the environment. These fire sites were replanted or restored to prevent water pollution problems. Therefore, in general, non-point source pollutants do not pose a significant threat to the INEEL's public water systems.

\subsubsection{Facility-Specific Known/Potential Sources of Groundwater Contamination. To} determine which known/potential sources of contamination may threaten the INEEL's public water systems, the capture zone maps were reviewed along with the list of potential contaminant sources compiled in the INEL Groundwater Monitoring Plan (DOE/ID-10441 1993) and the INEEL Groundwater Monitoring Plan Update (DOE/ID-11034 2002). Additional information was obtained from reviewing the INEEL Liquid Effluent Inventory and by data maintained by various organizations in the INEEL's Geospatial Laboratory. Because of the possibility of lateral migration of contaminants moving through the thick unsaturated zone, listed facilities were not strictly limited to those that fell within the capture zones; nearby facilities also were included.

\subsection{Argonne National Laboratory-West}

2.2.2.1.1 General Contaminant Information-Argonne National Laboratory-West (ANL-W) uses numerous chemicals and radioactive materials, resulting in the generation of a variety of hazardous, radioactive, and mixed wastes. A very detailed description of the known and potential sources of contamination at the ANL-W is provided in the INEL Groundwater Monitoring Plan (DOE/ID-10441 1993) and updated in the INEEL Groundwater Monitoring Plan Update (DOE/ID-11034 2002).

Although contaminants have been released to the environment at ANL-W, due to the great depth to groundwater, most of these releases are not considered to be a likely source of groundwater contamination. The facilities of primary interest with regard to evaluating groundwater impacts are those that handle, or have handled in the past, large volumes of potentially hazardous or radioactive solutions or wastewaters, and that are not equipped with adequate secondary containment, or that intentionally discharge to the environment. At ANL-W, these may include: the industrial wastewater pond, sanitary 
sewage lagoons, the EBR-II leach pit, and cooling tower blowdown ditches. Potential sources of groundwater contamination from these sources are provided in Table 2-12.

Although these contaminants were released to the environment at ANL-W, they have not been detected in significant quantities in the public water system, nor are they currently released in regulated quantities.

Table 2-12. Argonne National Laboratory-West constituents of concern for source water protection. ${ }^{\text {a }}$

\begin{tabular}{llll}
\hline \multicolumn{1}{c}{ Source } & \multicolumn{1}{c}{ Waste Type } & Constituent of Interest & \multicolumn{1}{c}{ Comments } \\
\hline $\begin{array}{l}\text { Industrial Waste Pond } \\
\text { and 3 ditches (ANL-01) }\end{array}$ & Process wastewater & $\begin{array}{l}\text { Chromium III, mercury, } \\
\text { selenium, Cs-137, zinc }\end{array}$ & $\begin{array}{l}\text { Contaminants from past } \\
\text { operational practice; } \\
\text { currently operational. }\end{array}$ \\
$\begin{array}{l}\text { Interceptor Canal and } \\
\text { Mound (ANL-09) }\end{array}$ & $\begin{array}{l}\text { Condensates, } \\
\text { radioactive effluent }\end{array}$ & Cs-137 & Past practice \\
$\begin{array}{l}\text { Main Cooling Tower } \\
\text { Blowdown Ditches } \\
\text { (ANL-01A) }\end{array}$ & $\begin{array}{l}\text { Industrial wastewater } \\
\text { from ion exchange and } \\
\text { cooling tower }\end{array}$ & Chromium III, mercury & Past practice \\
$\begin{array}{l}\text { Sanitary Sewage } \\
\text { Lagoons (ANL-04) }\end{array}$ & $\begin{array}{l}\text { Sanitary sewage, } \\
\text { industrial wastewater }\end{array}$ & Mercury & Contaminants from past \\
$\begin{array}{l}\text { Industrial Lift Station } \\
\begin{array}{l}\text { Discharge Ditch } \\
\text { (ANL-35) }\end{array}\end{array}$ & Industrial wastewater & Silver & $\begin{array}{l}\text { operational practice; } \\
\text { currently operational. }\end{array}$ \\
\hline \multicolumn{2}{l}{ After INEEL Groundwater Monitoring Plan Update (DOE/ID-11034), September 2002. } & Past practice \\
\hline
\end{tabular}

\subsection{Wellhead Protection Area Contaminant Information-Potential}

sources of contamination include the industrial waste pond and associated ditches, interceptor canal and mound, the main cooling tower blowdown ditches, sanitary sewage lagoons, and an industrial lift station discharge ditch. An industrial waste pond ditch is within the sanitary setback wellhead protection area of EBR-II \#2; the main cooling tower blowdown ditches and industrial waste pond are within the 500-foot circular zone radius for EBR-II \#2; and the sanitary sewage lagoons are just outside the three-year travel time of EBR-II \#2. The industrial waste pond ditches are within the 500-foot circular zone radius of EBR-II \#1.

Table 2-10 provides an overview of the potentially significant sources of groundwater contamination in relationship to the INEEL's wellhead protection areas. A facility-specific map of ANL-W's wellhead protection area is given in Appendix A, and a summary of the potential sources is given in Appendix B. However, all sources, except those listed in Table 2-12, were evaluated during the CERCLA investigative process and are no longer considered potential sources of significant groundwater contamination.

\subsection{Central Facilities Area}

2.2.2. $\quad$ General Contaminant Information-Although no reactors, processing activities, or major manufacturing activities at Central Facilities Area (CFA) would produce large quantities of wastes, numerous, mostly small potential sources of contamination are dispersed over a large portion of CFA. Known or potential sources include: the CFA landfills, a central sanitary sewage 
treatment plant, injection wells, laboratory effluents, underground storage tanks, and past releases of radioactive and chemical constituents to the environment. A detailed description of the known and potential sources of contamination at the CFA is provided in the INEL Groundwater Monitoring Plan (DOE/ID-10441 1993) and updated in the INEEL Groundwater Monitoring Plan Update

(DOE/ID-11034 2002). Known or potential sources of groundwater contamination from these sources are provided in Table 2-13.

Table 2-13. Central Facilities Area constituents of interest for source water protection. ${ }^{\text {a }}$

\begin{tabular}{|c|c|c|c|}
\hline Source & Waste Type & Constituent of Interest & Comments \\
\hline CFA-04 Pond & Laboratory wastewater & $\begin{array}{l}\text { Radionuclides, metals } \\
\text { (specifically mercury), } \\
\text { PCBs }\end{array}$ & Past practice \\
\hline $\begin{array}{l}\text { CFA-08 Sewage } \\
\text { Treatment Plant } \\
\text { Drainfield }\end{array}$ & Sanitary sewage & $\begin{array}{l}\text { Radionuclides, metals } \\
\text { (mercury and lead } \\
\text { particularly), PCBs and } \\
\text { nitrates }\end{array}$ & Past practice \\
\hline $\begin{array}{l}\text { CFA-05 Motor Pool } \\
\text { Pond }\end{array}$ & $\begin{array}{l}\text { Vehicle maintenance } \\
\text { wastewater }\end{array}$ & $\begin{array}{l}\text { Metals and volatile } \\
\text { organic compounds }\end{array}$ & Past practice \\
\hline $\begin{array}{l}\text { CFA Sewage Treatment } \\
\text { Plant }\end{array}$ & Sanitary sewage & $\begin{array}{l}\text { Nitrate/nitrite, total } \\
\text { dissolved solids, total } \\
\text { phosphorus }\end{array}$ & $\begin{array}{l}\text { Current operational } \\
\text { practice }\end{array}$ \\
\hline $\begin{array}{l}\text { CFA Landfills I, II and } \\
\text { III }\end{array}$ & $\begin{array}{l}\text { Domestic garbage, } \\
\text { industrial waste, } \\
\text { construction debris }\end{array}$ & $\begin{array}{l}\text { Volatile organic } \\
\text { compounds, metals, } \\
\text { total dissolved solids, } \\
\text { anions }\end{array}$ & $\begin{array}{l}\text { Landfills I, II -past } \\
\text { practices; Landfill III } \\
\text { currently operating }\end{array}$ \\
\hline
\end{tabular}

a. After INEEL Groundwater Monitoring Plan Update (DOE/ID-11034), September 2002

Although contaminants have been released to the environment at CFA, only one of the CFA contaminant sources is suspected to have caused groundwater contamination. Nitrate contamination, thought to have originated at the old CFA Sewage Treatment Plant, has been detected in the groundwater beneath CFA. Additional groundwater contamination beneath CFA is thought to be due to underground injection and land disposal practices at TRA and INTEC. From the early 1950s until the mid-1980s, wastewater containing tritium was disposed of to the Snake River Plain Aquifer at TRA and INTEC through injection wells and infiltration ponds. These are the suspected source of tritium contamination in the CFA water supply wells.

2.2.2.2.2 Wellhead Protection Area Contaminant Information-Significant potential sources of contamination include CFA Landfill II, which is within the wellhead protection area of well CFA-02. The wellhead protection area of well CFA-01 does not underlie any of the potential sources of groundwater contamination identified at CFA. The old sewage treatment plant at CFA-691, the CFA-617 central laundry, the CFA-633 laboratories, and the CFA-637 hazardous waste storage facility appear to lie across the regional gradient east of the well. The CFA-01 wellhead protection area passes beneath a storage area west of CFA-633. North of that, it underlies a gravel pit that appears in 1990 aerial photographs to have been in the process of being filled with construction rubble. Both of these features are within the well's 2-year capture zone. 
Because well CFA-02 is farther south than CFA-01 and because its wellhead protection area is broader, the area underlies a larger portion of the CFA developed area than does that of CFA-01. Although the wellhead protection area includes more buildings than the CFA-01 zone, these are mostly office buildings or other facilities in which hazardous materials are not handled, and they have little potential to cause groundwater contamination. However, the new bus shop is within the CFA-02 3-year capture zone. Landfill II is within the 6-year capture zone.

Both CFA-01 and CFA-02 are within the tritium plume originating at INTEC and TRA. CFA is close enough to the channel of the Big Lost River that groundwater flow directions might be marginally changed in response to flow in the river. If such a change occurred, the capture zones might show a more northwesterly trend. However, the effects of surface water flow are likely much less at CFA than they would be at RWMC or INTEC. Therefore, this is not a significant issue.

Table 2-10 provides an overview of the potentially significant sources of groundwater contamination in relationship to the INEEL's wellhead protection areas. A facility-specific map of CFA's wellhead protection area and potentially significant contaminant sources is given in Appendix A, and a summary of the potentially significant sources is given in Appendix B.

\subsection{Experimental Breeder Reactor-I}

2.2.2.2.1 General Contaminant Information-A detailed evaluation of Experimental Breeder Reactor-I (EBR-I) was conducted during the development of the INEL Groundwater Monitoring Plan (DOE/ID-10441 1993). Although the 1993 plan evaluated 16 potential sources of contamination at EBR-I, it concluded that there were no likely sources of potential groundwater contamination. This evaluation was confirmed during the development of the 2002 INEEL Groundwater Monitoring Plan Update (DOE/ID-11034 2002).

Figure 2-19 indicates that the wellhead protection area does not encompass any facilities that have the potential to cause groundwater contamination. Moreover, it is unlikely that contaminants released at the surface in the vicinity of this wellhead could influence the quality of water pumped from it because the well's completion interval is deep. In fact, the well appears to pump water from an interval below the tritium plume originating at TRA and INTEC.

\subsection{Wellhead Protection Area Contaminant Information-No}

facilities have the potential to affect groundwater quality within the capture zone of the EBR-I production well. The well is offset from both the EBR-I and BORAX sites, and the wellhead protection area encompasses only a small area. Although the road to RWMC crosses the well's capture zone outline, the well's completion interval is so deep that it is doubtful that any surface release at that location would show up in the well. Although observations from wells surrounding EBR-I indicate that this area is within the INTEC/TRA tritium plume, tritium is not detected here. This indicates that the well is completed deeper than the plume level. Therefore, surface releases within the capture zones would not actually appear in the well.

\subsection{Gun Range}

2.2.2.2.1 General Contaminant Information-A detailed evaluation of the Gun Range facility was conducted during the development of the INEL Groundwater Monitoring Plan (DOE/ID-10441 1993). No known processes handle hazardous materials or generate hazardous wastes, hence, no known sources of groundwater contamination have been identified at the Gun Range. The only potential source of contamination comes from lead bullets in earthen berms behind the target areas. Because of the arid environment and alkaline soils at the INEEL, this lead would be very immobile; 
therefore, no known potential sources of groundwater contamination are at the Gun Range. This evaluation was confirmed during the development of the INEEL Groundwater Monitoring Plan Update (DOE/ID-11034 2002).

\subsection{Wellhead Protection Area Contaminant Information-The Gun} Range wellhead protection area does not coincide with any other developed areas. The Naval Ordnance Disposal Area (NODA) lies northwest of the capture zones. However, the Gun Range well is close enough to the Big Lost River that infiltration from periodic surface water flow in the river might be expected to cause a change in aquifer flow direction. Flow could assume a more northerly direction, and the capture zone could pass beneath the NODA. Because large volumes of liquid are generally considered necessary to carry contaminants through the thick unsaturated zone to the aquifer, and because only ordnance is known to have been disposed at NODA, it appears unlikely that NODA presents a contamination threat to the Gun Range well.

Table 2-10 provides an overview of the potentially significant sources of groundwater contamination in relationship to the INEEL's wellhead protection areas. A facility-specific map of the Gun Range's wellhead protection area and potentially significant contaminant sources is given in Appendix A, and a summary of the potentially significant sources is given in Appendix B.

\subsection{Idaho Nuclear Technology and Engineering Center}

2.2.2. 2.1 General Contaminant Information-A detailed description of the known and potential sources of contamination at the Idaho Nuclear Technology and Engineering Center (INTEC) is provided in the INEL Groundwater Monitoring Plan (DOE/ID-10441 1993). This evaluation found many significant sources of potential groundwater contamination. However, the INEEL Groundwater Monitoring Plan Update (DOE/ID-11034 2002) found that many of these potential sources were subsequently either not significant or were remediated during the INEEL's ongoing CERCLA activities. Known or potential sources of groundwater contamination from these sources are provided in Table 2-14.

Numerous chemicals and radioactive materials have been used for INTEC operations, resulting in generation of a variety of hazardous, radioactive, and mixed wastes. INTEC facilities have included Resources Conservation and Recovery Act (RCRA) facilities and radiological treatment and storage facilities managed in accordance with the appropriate guidance and criteria. These regulated units primarily consist of waste storage tanks and thermal treatment facilities. These facilities typically have adequate containment and secondary containment to guard against environmental contamination from an accidental release.

Over the years, hazardous and radioactive wastes have been released to the environment, both intentionally and unintentionally. These include spill sites, solid waste disposal sites, liquid waste disposal sites, and releases to the atmosphere. However, the INTEC Tank Farm, old service waste percolation ponds, and the INTEC deep injection well are the primary facilities of interest with regard to groundwater contamination. The latter two facilities were formerly used to discharge large quantities of process waste to the land surface and to the eastern Snake River Plain Aquifer. Many of the radionuclides in the eastern Snake River Plain Aquifer downgradient of INTEC originated at the INTEC injection well or percolation ponds. Those contaminants include a wide variety of radionuclides, mercury, total dissolved solids, nitrate, chloride, and sodium. Because of process restrictions, few organic compounds have been released from these facilities. These contaminants are found in the perched water zones beneath the INTEC, as throughout the southwestern portion of the INEEL, and some have been detected in low quantities off-Site. 
Table 2-14. Idaho Nuclear Technology and Engineering Center constituents of interest for source water protection. ${ }^{\mathrm{a}}$

\begin{tabular}{llll}
\hline \multicolumn{1}{c}{ Source } & \multicolumn{1}{c}{ Waste Type } & Constituent of Interest & \multicolumn{1}{c}{ Comments } \\
\hline $\begin{array}{l}\text { CPP-23 Injection Well } \\
\text { CPP-96 Tank Farm }\end{array}$ & $\begin{array}{l}\text { Process wastewater } \\
\text { High-level/low-level } \\
\text { radioactive waste } \\
\text { storage }\end{array}$ & $\begin{array}{l}\text { Radionuclides, mercury } \\
\text { Radionuclides, mercury, } \\
\text { nitrate }\end{array}$ & $\begin{array}{l}\text { Past practice } \\
\text { Past practice }\end{array}$ \\
$\begin{array}{l}\text { Old Service Waste } \\
\text { Percolation Ponds }\end{array}$ & $\begin{array}{l}\text { Industrial process } \\
\text { wastewater }\end{array}$ & $\begin{array}{l}\text { Radionuclides, total } \\
\text { dissolved solids, } \\
\text { chloride, sodium }\end{array}$ & Past practice \\
$\begin{array}{l}\text { New Service Waste } \\
\text { Percolation Ponds }\end{array}$ & $\begin{array}{l}\text { Industrial process } \\
\text { wastewater }\end{array}$ & $\begin{array}{l}\text { Total dissolved solids, } \\
\text { chloride, sodium }\end{array}$ & $\begin{array}{l}\text { Current operational } \\
\text { practice }\end{array}$ \\
$\begin{array}{l}\text { Sewage Treatment Plant } \\
\text { Rapid Infiltration }\end{array}$ & Sanitary sewage & $\begin{array}{l}\text { Total dissolved solids, } \\
\text { chloride, nitrate }\end{array}$ & $\begin{array}{l}\text { Current operational } \\
\text { practice }\end{array}$ \\
\hline a. After INEEL Groundwater Monitoring Plan Update (DOE/ID-11034), September 2002. & \\
\hline
\end{tabular}

Discharges from the sewage treatment plant, apparent leakage from piping systems, and local water use in the northern half of INTEC have produced perched water bodies that extend to the north some unknown distance beyond the boundaries of the source facilities. An additional increment of northward migration can be expected to take place (at least for a portion of the discharge) between the bottoms of the perched water bodies and the water table, so that water discharged at the surface conceivably could reach these wells. Although this possibility should be kept in mind, the absence of observed water quality problems in these wells suggests that the existing processes are not a problem.

\subsection{Wellhead Protection Area Contaminant Information-The two} INTEC wells, CPP-04 and CPP-05, are located off the northeast corner of INTEC, upgradient from all development associated with the facility (Figure 2-21). Their capture zones extend toward the northeast, occupying exclusively undeveloped areas. Although the capture zones would appear to make these wells relatively invulnerable to groundwater contamination originating at INTEC, it does not account for the presence of expansive perched water bodies at the northern end of INTEC.

Because the wells are located at the north, upgradient edge of INTEC, their associated capture zones overlap no INTEC facilities that would be expected to threaten groundwater. However, this ignores the possible presence of perched water bodies whose extent may be greater than or offset from their surface sources. It also ignores transient effects, such as changing flow directions in response to occasional infiltration from surface water in the Big Lost River channel. These points are mentioned here because contaminants have been found in production wells CPP-01 and CPP-02, demonstrating that some INTEC sources of contamination have contributed contaminants to the wells despite the fact that the calculated capture zones do not overlap INTEC facilities thought to potentially threaten groundwater.

Table 2-10 provides an overview of the potentially significant sources of groundwater contamination in relationship to the INEEL's wellhead protection areas. A facility-specific map of the INTEC's wellhead protection area and potentially significant contaminant sources is given in Appendix A, and a summary of the potentially significant sources is given in Appendix B. 


\subsection{Main Gate Facility}

2.2.2.2.6.1 General Contaminant Information-A detailed evaluation of the Main Gate Facility was conducted during the development of the INEL Groundwater Monitoring Plan (DOE/ID-10441 1993). The only liquid wastes generated are sanitary wastes discharged through a septic tank and seepage pit. No activities conducted at the Main Gate Facility generate hazardous waste or use hazardous materials in a process; therefore, no potential sources of groundwater contamination are at this facility. This evaluation was confirmed during the INEEL Groundwater Monitoring Plan Update (DOE/ID-11034 2002).

\subsection{Wellhead Protection Area Contaminant Information-The Main}

Gate Facility wellhead protection area does not intersect any developed areas that could contribute contaminants to the facility's public water system. Furthermore, no hazardous or radioactive materials are managed, stored, or disposed of at the Main Gate Facility. However, the Main Gate Facility is the primary point of entry for commercial vehicles entering the INEEL. While it is unlikely that contaminants would be released from vehicles near this well (it is located near the roadway, but not near where large trucks park or are processed), it is unlikely that contaminants released from a vehicle during an accident would significantly impact the well.

Table 2-10 provides an overview of the potentially significant sources of groundwater contamination in relationship to the INEEL's wellhead protection areas. A facility-specific map of the Main Gate's wellhead protection area and potentially significant contaminant sources is given in Appendix A, and a summary of the potentially significant sources is given in Appendix B.

\subsubsection{Naval Reactors Facility}

2.2.2.7.1 General Contaminant Information-Detailed evaluations of the known and potential sources of groundwater contamination at the Naval Reactors Facility (NRF) have been performed (WEC 1994 and WEC 1997). These evaluations found several possible sources of groundwater contamination.

The most significant sources of potential groundwater contamination are the NRF industrial waste ditch (IWD), the NRF sewage lagoons (SLs), and S1W leaching beds. The IWD and SLs, are active; however, discharges to the leaching beds ended approximately 24 years ago. Current detections in groundwater due to the leaching beds are remnants from prior discharges. Known or potential sources of groundwater contamination from these sources are provided in Table 2-15.

2.2.2.7.2 Wellhead Protection Area Contaminant Information-The two NRF wells that furnish drinking water exclusively, NRF-2 and NRF-3, are near the center of the facility, downgradient to the IWD and SLs, but upgradient relative to the S1W leaching beds. The 3-year capture zone for these wells extends northward, and encompasses all of the IWD and SLs. Constituents released from the IWD and SLs included: calcium, chloride, potassium, sodium, and sulfate. The concentration of these nonhazardous water softening and demineralization process ions were below applicable drinking water limits and had no detrimental effect on the quality of the groundwater. The concentrations of aluminum, iron, and manganese from the IWD and SLs were also elevated compared to background in the groundwater monitoring wells. However, these metals have not been detected in drinking water. Groundwater at NRF also contains slightly elevated levels of tritium compared to background. However, these levels are approximately 100 times less than the drinking water limit. The source of tritium is 
Table 2-15. Naval Reactors Facility constituents of interest for source water protection. ${ }^{\text {a }}$

\begin{tabular}{llll}
\hline \multicolumn{1}{c}{ Source } & \multicolumn{1}{c}{ Waste Type } & Constituent of Interest & \multicolumn{1}{c}{ Comments } \\
\hline $\begin{array}{l}\text { NRF Industrial Waste } \\
\text { Ditch }\end{array}$ & Industrial waste & $\begin{array}{l}\text { Calcium, chloride, } \\
\text { potassium, sodium, } \\
\text { sulfate, aluminum, iron, } \\
\text { manganese }\end{array}$ & $\begin{array}{l}\text { Current operational } \\
\text { practice }\end{array}$ \\
NRF sewage lagoons & Sanitary waste & $\begin{array}{l}\text { Calcium, chloride, } \\
\text { potassium, sodium, } \\
\text { sulfate, aluminum, iron, } \\
\text { magnesium, nitrate, } \\
\text { TOC }\end{array}$ & $\begin{array}{l}\text { Current operational } \\
\text { practice }\end{array}$ \\
& & Tritium & Past practice \\
S1W leaching beds & & \\
\hline a. Information from WEC 1994 and WEC 1997. & & \\
\hline
\end{tabular}

downgradient of the capture zones for the drinking water wells and therefore does not pose a problem. The 6-year and 10-year capture zones for the NRF drinking water wells both underlie uninhabited areas of the INEEL, which do not contain any potential sources of groundwater contamination.

Table 2-10 provides an overview of the potentially significant sources of groundwater contamination in relationship to the INEEL's wellhead protection areas. A facility-specific map of the NRF's wellhead protection area and potentially significant contaminant sources is given in Appendix A, and a summary of the potentially significant sources is given in Appendix B.

\subsection{Power Burst Facility}

2.2.2. operational area consists of five sites: the PBF Control Area, PBF/SPERT I area, the Waste Engineering Development Facility, the Waste Experimental Reduction Facility, and the Mixed Waste Storage Facility. A detailed description of the known and potential sources of contamination at the PBF area is provided in the INEL Groundwater Monitoring Plan (DOE/ID-10441 1993). This evaluation found a few potentially significant sources of groundwater contamination.

The most significant sources of potential groundwater contamination are the injection wells and infiltration ponds, which over the years have received substantial quantities of chemicals and radionuclides in large volumes of wastewater. Of lesser importance are various sites where unintentional releases of contaminants may have occurred. This is due to the belief that many of these unintentional releases may not have been accompanied by sufficient volumes of liquid to drive the contaminants to the aquifer. The INEEL Groundwater Monitoring Plan Update (DOE/ID-11034 2002) concluded that many of these potential sources were either not significant potential sources of contamination or they were remediated during the INEEL's ongoing CERCLA activities. Known or potential sources of groundwater contamination from these sources are provided in Table 2-16. 
Table 2-16. Power Burst Facility constituents of interest for source water protection. ${ }^{\text {a }}$

\begin{tabular}{llll}
\hline \multicolumn{1}{c}{ Source } & \multicolumn{1}{c}{ Waste Type } & \multicolumn{1}{c}{ Constituent of Interest } & \multicolumn{1}{c}{ Comments } \\
\hline $\begin{array}{l}\text { PER-16 SPERT II } \\
\text { Leach Pond }\end{array}$ & $\begin{array}{l}\text { Demineralizer wastes } \\
\text { and water softener } \\
\text { wastes, floor drains } \\
\text { Low-level radioactive }\end{array}$ & $\begin{array}{l}\text { Metals (mercury and } \\
\text { sodium), total dissolved } \\
\text { solids, sulfate } \\
\text { Radionuclides }\end{array}$ & Past practice \\
$\begin{array}{l}\text { Waste Injection Well } \\
\text { PER-302 PBF Reactor } \\
\text { Area Corrosive Water } \\
\text { Waste Injection Well }\end{array}$ & $\begin{array}{l}\text { Demineralizer wastes, } \\
\text { secondary coolant water }\end{array}$ & $\begin{array}{l}\text { Sulfate, phosphate, } \\
\text { metals (sodium and } \\
\text { chromium) total } \\
\text { dissolved solids, sulfate }\end{array}$ & Past practice \\
SL-1 Burial Ground & $\begin{array}{l}\text { Contaminated soil, } \\
\text { remains of SL-1 reactor }\end{array}$ & Radionuclides & Low-level waste landfill \\
& & \\
\hline
\end{tabular}

\subsection{Wellhead Protection Area Contaminant Information-The}

wellhead protection area of the two PBF-area production wells does not appear to directly underlie any facilities where potential groundwater contaminants are used or handled in quantity (Figure 2-24). The capture zone of well SPERT 1 passes northwest of the PBF control area septic system, with its four seepage basins. Because of the likelihood of lateral migration of treated septic wastewater as it moves down through the vadose zone, some small fraction of the water withdrawn from the well might come from this source. PBF is far enough from the Big Lost River that groundwater flow directions are unlikely to be influenced by surface water infiltration from that source.

Table 2-10 provides an overview of the potentially significant sources of groundwater contamination in relationship to the INEEL's wellhead protection areas. A facility-specific map of the PBF's wellhead protection area and potentially significant contaminant sources is given in Appendix A, and a summary of the potentially significant sources is given in Appendix B.

\subsection{Radioactive Waste Management Complex}

2.2.2.2.9.1 General Contaminant Information-A detailed description of the known and potential sources of contamination at the Radioactive Waste Management Complex (RWMC) is provided in the INEL Groundwater Monitoring Plan (DOE/ID-10441 1993) and updated in the INEEL Groundwater Monitoring Plan Update (DOE/ID-1 1034 2002). Those documents found that the area of interest, as far as potential sources of groundwater contamination is concerned, is the Subsurface Disposal Area (SDA). Large quantities of various solid and liquid radioactive and chemical wastes, including transuranic wastes and organic wastes, have been disposed underground in pits, trenches, and vaults in the Subsurface Disposal Area and abovegrade on large covered pads at the RWMC. Known or potential sources of groundwater contamination from these sources are provided in Table 2-17.

Numerous radionuclides and organic compounds such as carbon tetrachloride, trichloroethylene, tetrachloroethylene, toluene, benzene, 1,1,1-trichloroethane, and lubricating oil have been disposed of in the RWMC and have been detected in the vadose zone and groundwater beneath the RWMC. However, these have not exceeded the maximum contaminant level in the public water system itself. In addition, at least two radionuclides, tritium and strontium-90, are currently present above background levels in the groundwater near the RWMC. The tritium in the RWMC wells probably originated from wastewater disposal practices at INTEC and TRA. However, local waste disposal may also be contributing to the 
Table 2-17. Radioactive Waste Management Complex constituents of interest for source water protection. $^{\mathrm{a}}$

\begin{tabular}{llll}
\hline \multicolumn{1}{c}{ Source } & \multicolumn{1}{c}{ Waste Type } & Constituent of Interest & \multicolumn{1}{c}{ Comments } \\
\hline $\begin{array}{l}\text { Subsurface Disposal } \\
\text { Area }\end{array}$ & $\begin{array}{l}\text { Wastes associated with } \\
\text { the manufacturing of } \\
\text { nuclear weapons, } \\
\text { reactor operations, and } \\
\text { laboratory studies }\end{array}$ & $\begin{array}{l}\text { Radionuclides, volatile } \\
\text { organic compounds, } \\
\text { nitrate, metals } \\
\text { (chromium) }\end{array}$ & $\begin{array}{l}\text { Current operations and } \\
\text { past practices }\end{array}$ \\
& & \\
& & \\
a. After the INEEL Groundwater Monitoring Plan Update (DOE/ID-11034), September 2002. & \\
\hline
\end{tabular}

tritium near RWMC. Strontium detected in RWMC monitoring wells probably originated from disposal sites at the RWMC. Chromium has been detected above established maximum contaminant levels. Also, sodium, chloride, and nitrate concentrations are elevated in the groundwater as a result of RWMC activities.

\subsection{Wellhead Protection Area Contaminant Information-The}

RWMC wellhead protection area does not intersect any other facilities that manage hazardous or radioactive materials that could threaten groundwater. However, it does include all of the RWMC Administrative Area and Transuranic Storage Area, and parts of the Subsurface Disposal Area. The historical and ongoing activities in the Administrative Area do not threaten groundwater quality at the wellhead, and because of the way materials are stored and managed in the Transuranic Storage Area, they probably do not threaten groundwater quality either. However, because of the materials stored and disposed of in the Subsurface Disposal Area and the types of historical activities, most of the chemical and radiological materials discussed above potentially could impact the RWMC production well.

Presently, the contaminant of greatest concern is carbon tetrachloride. The concentrations of carbon tetrachloride at the RWMC are at or near the SDWA maximum contaminant level $(5.0 \mu \mathrm{g} / \mathrm{L})$. In addition, groundwater modeling predicts the concentration of these organic compounds will continue to increase in the future. The capture zone map does not by itself indicate that the RWMC production well will become contaminated above maximum contaminant levels. However, in view of the history of operations at the SDA and the levels of hydrocarbon contamination in nearby monitoring wells, increased water quality problems at the well would not be surprising.

Table 2-10 provides an overview of the potentially significant sources of groundwater contamination in relationship to the INEEL's wellhead protection areas. A facility-specific map of the RWMC's wellhead protection area and potentially significant contaminant sources is given in Appendix A, and a summary of the potentially significant sources is given in Appendix B.

\subsection{Test Area North}

2.2.2.10.1 General Contaminant Information-Detailed descriptions of the known and potential sources of contamination at Test Area North (TAN) were provided in the INEL Groundwater Monitoring Plan (DOE/ID-10441 1993). According to the INEEL Groundwater Monitoring Plan Update (DOE/ID-11034 2002), subsequent investigations found several of these potential sources of contamination were either not significant threats to contaminate the groundwater at TAN or are being remediated as part of the INEEL's ongoing CERCLA program. However, wastewater infiltration ponds, injection wells, spills, and underground tanks still remain. 
Three significant known or potential sources of groundwater contamination are at TAN. These sources are provided in Table 2-18. Groundwater contaminants have been detected in the vadose zone and in the perched water body beneath the TSF-07 pond. In addition, groundwater monitoring has revealed an extensive plume of radiological and organic contamination in the eastern Snake River Plain Aquifer, extending from the TSF injection well (TSF-05) to WRRTF. The primary contaminant of concern at TSF is trichloroethylene (TCE). TCE has been detected in both TSF-01 and TSF-02 wells since 1987. A sparger system (air stripping process) has been used in the water storage tank to volatilize the trichloroethylene to levels below the SDWA maximum contaminant level. Groundwater in this area is the subject of a current CERCLA Remedial Investigation/Feasibility Study. Low-level radionuclides, volatile organic compounds, inorganic compounds, and metals associated with the disposal ponds are typically below maximum contaminant levels; however, several of them are at sufficiently high levels that they are of interest for future monitoring.

Table 2-18. Test Area North constituents of interest for source water protection. ${ }^{\mathrm{a}}$

\begin{tabular}{|c|c|c|c|}
\hline Source & Waste Type & Constituent of Interest & Comments \\
\hline $\begin{array}{l}\text { TSF-05 } \\
\text { Injection Well }\end{array}$ & $\begin{array}{l}\text { Industrial wastewater and } \\
\text { sanitary sewage }\end{array}$ & $\begin{array}{l}\text { Trichloroethylene, } \\
\text { tetrachloroethylene, } \\
\text { cis- and trans- } \\
\text { dichloroethene, vinyl } \\
\text { chloride, Sr-90, Cs-137, } \\
\text { tritium, U-234 }\end{array}$ & Past practices \\
\hline $\begin{array}{l}\text { TSF-07 Disposal } \\
\text { Pond }\end{array}$ & $\begin{array}{l}\text { Sanitary sewage from } \\
\text { TAN/TSF facilities, } \\
\text { hazardous and radioactive } \\
\text { wastes }\end{array}$ & $\begin{array}{l}\text { Low-level radionuclides, } \\
\text { volatile organic } \\
\text { compounds, sulfate, } \\
\text { nitrate, phosphate, } \\
\text { chloride, total dissolved } \\
\text { solids, iron, sodium }\end{array}$ & $\begin{array}{l}\text { Past practices (hazardous/ } \\
\text { radioactive disposal) } \\
\text { Ongoing operations for } \\
\text { sanitary sewage }\end{array}$ \\
\hline $\begin{array}{l}\text { CTF Disposal } \\
\text { Pond }\end{array}$ & $\begin{array}{l}\text { Heat exchanger cooling } \\
\text { water, floor drains, boiler } \\
\text { blowdown, sanitary } \\
\text { sewage, ion exchange } \\
\text { regeneration fluids }\end{array}$ & $\begin{array}{l}\text { Low-level radionuclides, } \\
\text { volatile organic } \\
\text { compounds, metals, } \\
\text { sulfate }\end{array}$ & Past practices \\
\hline
\end{tabular}

\subsection{Wellhead Protection Area Contaminant Information-As}

Figure 2-26 shows, the wells and their associated capture zones are offset to the east from the main TAN/CTF developed area. Thus, they do not overlap facilities where activities are likely to threaten groundwater.

The well locations, in combination with an observed flow direction from the north-northwest, result in calculated capture zones that, for the most part, skirt the TAN/TSF developed area. However, trichloroethylene and other contaminants in the TAN/TSF wells are known to originate at the TSF-03 injection well, which demonstrates that the capture zones produced using the model are not adequate to fully define the possible source areas for groundwater contamination in this case. Several factors probably cause this discrepancy. The most important of these is suspected to be aquifer heterogeneity. As explained in Section 2.1.4.1, the RESSQC model uses average values for aquifer variables. It cannot account for the degree of aquifer heterogeneity, which is known to exist in the Snake River Plain Aquifer. Transient effects such as changing flow directions could contribute to divergence between the observed and 
modeled results. Also, the model does not account for dispersion. The effect of dispersion is to allow contaminants to move along paths that are not strictly coincident with flow lines. In addition to the known contaminants, the TAN-2 well must be mentioned. This well is near three fuel oil tanks with a combined capacity of nearly 500,000 gallons.

Table 2-10 provides an overview of the potentially significant sources of groundwater contamination in relationship to the INEEL's wellhead protection areas. A facility-specific map of the TAN/CTF's and TAN/TSF's wellhead protection areas and potentially significant contaminant sources is given in Appendix A, and a summary of the potentially significant sources is given in Appendix B.

\subsection{Test Reactor Area}

2.2.2.11.1 General Contaminant Information-A detailed description of the known and potential sources of contamination at the Test Reactor Area (TRA) is provided in the INEL Groundwater Monitoring Plan (DOE/ID-10441 1993). However, the INEEL Groundwater Monitoring Plan Update (DOE/ID-11034 2002) points out that subsequent investigations have found some of those potential contaminant sources are no longer significant issues and other sources have been removed via the INEEL's ongoing CERCLA activities. However, significant known/potential sources of groundwater contamination still remain at TRA. These sources include the residual contaminants from several historical injection wells and waste disposal ponds. Known or potential sources of groundwater contamination from these sources are provided in Table 2-19.

The TRA disposal ponds and an injection well collectively have been used for the disposal of several distinct waste streams of hazardous and low-level radioactive wastewater. Use of the infiltration ponds has caused the formation of perched water zones at two depth intervals beneath the facility. Significantly elevated levels of both radioactive and chemical constituents have been detected in water samples from these perched zones. Elevated levels of chromium, trichloroethylene, and tritium have been detected in the eastern Snake River Plain Aquifer in TRA wells. TRA and INTEC wastewater disposal practices have together contributed to a plume of tritium contamination in the aquifer that extends approximately to the southern boundary of the INEEL. Phenol is the only parameter at the TRA-04 well that exceeded regulatory limits for drinking water. Phenol was detected at a concentration of $0.007 \mathrm{mg} / \mathrm{L}$, which is above the State of Idaho secondary maximum contaminant level of $0.001 \mathrm{mg} / \mathrm{L}$.

2.2.2.11.2 Wellhead Protection Area Contaminant Information-Because flow in the aquifer here is from the north-northeast, most of the area underlain by the production well capture zones is undeveloped terrain in which no activities take place that threaten groundwater quality. However, the capture zones encompass a few potential contaminant sources. For example, they overlap a portion of the petroleum storage area, the north storage area, and several mounds of construction rubble. The zones do not overlap the chemical waste pond, but they do overlap the coalesced perched water zone that underlies that pond and several others further south. In addition, the capture zones underlie four large fuel oil and diesel storage tanks (727A through 727D), which are within or near the capture zone southwest of well TRA 04.

Also of significance are the perched water bodies associated with TRA's old infiltration ponds along the east boundary of the facility. Current discharges to the cold waste pond, sewage ponds, and chemical waste ponds (and past discharges to the now-discontinued warm waste ponds) are believed to coalesce at depth to form a single body of perched water above some of the deeper perching layers. However, the chemical waste pond would be the most likely source of wastewater reaching the aquifer within the production well capture zone. The overlap of the capture zone with perched water originating 
Table 2-19. Test Reactor Area constituents of interest for source water protection. ${ }^{\text {a }}$

\begin{tabular}{|c|c|c|c|}
\hline Source & Waste Type & Constituent of Interest & Comments \\
\hline $\begin{array}{l}\text { TRA-03 Warm Waste } \\
\text { Pond }\end{array}$ & $\begin{array}{l}\text { Low-level radioactive } \\
\text { waste from reactor } \\
\text { operations }\end{array}$ & $\begin{array}{l}\text { Radionuclides, metals, } \\
\text { (chromium in particular) }\end{array}$ & Past practice \\
\hline $\begin{array}{l}\text { TRA-04/05 Retention } \\
\text { Basin sediments }\end{array}$ & $\begin{array}{l}\text { Low-level radioactive } \\
\text { waste from reactor } \\
\text { operations }\end{array}$ & $\begin{array}{l}\text { Radionuclides, metals, } \\
\text { (chromium in particular) }\end{array}$ & Past practice \\
\hline TRA-05 Injection Well & $\begin{array}{l}\text { Low-level radioactive } \\
\text { waste from reactor } \\
\text { operations }\end{array}$ & $\begin{array}{l}\text { Radionuclides, metals, } \\
\text { (chromium in particular) }\end{array}$ & Past practice \\
\hline $\begin{array}{l}\text { TRA-06 Chemical } \\
\text { Waste Pond }\end{array}$ & $\begin{array}{l}\text { Demineralizer } \\
\text { regeneration solutions }\end{array}$ & $\begin{array}{l}\text { Metals (including } \\
\text { mercury and sodium,) } \\
\text { sulfate, total dissolved } \\
\text { solids }\end{array}$ & Past practice \\
\hline $\begin{array}{l}\text { TRA-08 Cold Waste } \\
\text { Pond }\end{array}$ & $\begin{array}{l}\text { Cooling tower effluent, } \\
\text { industrial process } \\
\text { wastewater }\end{array}$ & $\begin{array}{l}\text { Radionuclides, metals, } \\
\text { volatile organic } \\
\text { compounds, sulfate, } \\
\text { total dissolved solids }\end{array}$ & $\begin{array}{l}\text { Current operations and } \\
\text { past practice }\end{array}$ \\
\hline TRA-13 Sewage Pond & Sanitary sewage & $\begin{array}{l}\text { Nitrate, phosphate, } \\
\text { chloride }\end{array}$ & Past practice \\
\hline
\end{tabular}

at the chemical waste pond might appear to threaten water quality at the production wells (particularly at wells TRA-01 and TRA-03). However, many years of discharges from the pond have not caused noticeable deterioration in water quality at the wells.

\subsubsection{Significant Groundwater Contaminant Plumes at the INEEL}

General hydrologic conditions and the groundwater quality in these areas have been described in USGS studies since the 1950s. Examples of general reports include:

- $\quad$ Robertson et al. (1974)

- $\quad$ Barraclough et al. (1976)

- $\quad$ Barraclough and Jensen (1976)

- $\quad$ Barraclough et al. (1981)

- $\quad$ Lewis and Jensen (1984)

- $\quad$ Pittman et al. (1988)

- $\quad$ Orr and Cecil (1991)

- $\quad$ Bartholomay et al. 1998. 
In addition, the USGS also produced reports on individual contaminants or groups of contaminants, including of special interest:

- $\quad$ Mann and Knobel 1987 (purgeable organic compounds)

- $\quad$ Mann and Knobel 1988 (nine trace metals)

- $\quad$ Knobel and Mann 1988 (radionuclides)

- $\quad$ Mann et al. 1988 (iodine-129)

- $\quad$ Mann and Cecil 1990 (tritium).

Recently Bartholomay et al. 1998 reviewed selected contaminants and hydrologic conditions at the INEEL.

Operations at the INEEL have resulted in elevated concentrations of radiochemical and chemical constituents in the eastern Snake River Plain Aquifer at several locations within the INEEL. These constituents include: tritium, strontium-90, cobalt-60, cesium-137, plutonium, americium-241, chromium, sodium, chloride, sulfate, nitrate, and various volatile organic compounds. Some of the organic compounds associated with industrial processes at the INEEL in the aquifer include: benzene, bromoform, carbon tetrachloride, chloroform, dibromochloromethane, dichlorobromomethane, 1,4-dichlorobenzene, 1,2-dichloroethane, 1,1-dichloroethylene, 1,1,1-trichloroethane, trichloroethylene, and vinyl chloride. In general, these contaminants are found in very small quantities, and in general, these plumes tend to be downgradient of INTEC, RWMC, TRA and TAN.

Mann and Cecil USGS (1990) produced maps showing the development of the major groundwater contaminant plumes in the south-central portion of the INEEL. These plumes, which originate primarily from INTEC and TRA, include tritium, strontium-90, nitrate, and specific conductance. While they do not represent all of the potential contaminants, they are good indicators of the extent of groundwater contamination in this area. The horizontal distribution of these constituents in the aquifer has been estimated based on their concentration in wells. Vertical concentration variations are poorly known. Most recently in 1998, these plume maps were updated by Bartholomay et al. (1998) showing the extent of these plumes (Figures 2-30-2-35). 

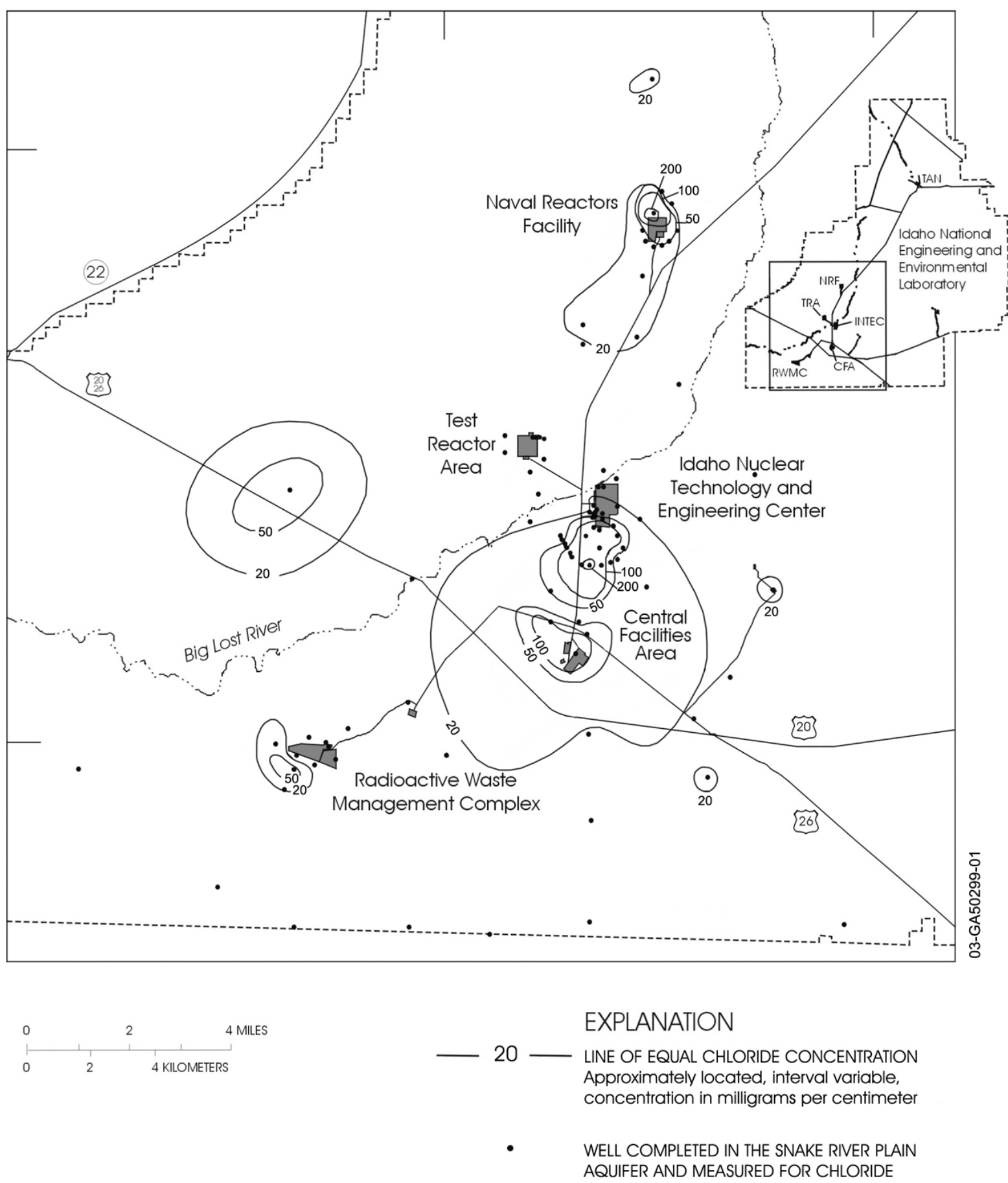

Figure 2-30. Distribution of chloride in water from the Snake River Plain Aquifer in the south-central part of the INEEL, 1988 (Bartholomay 1998). 

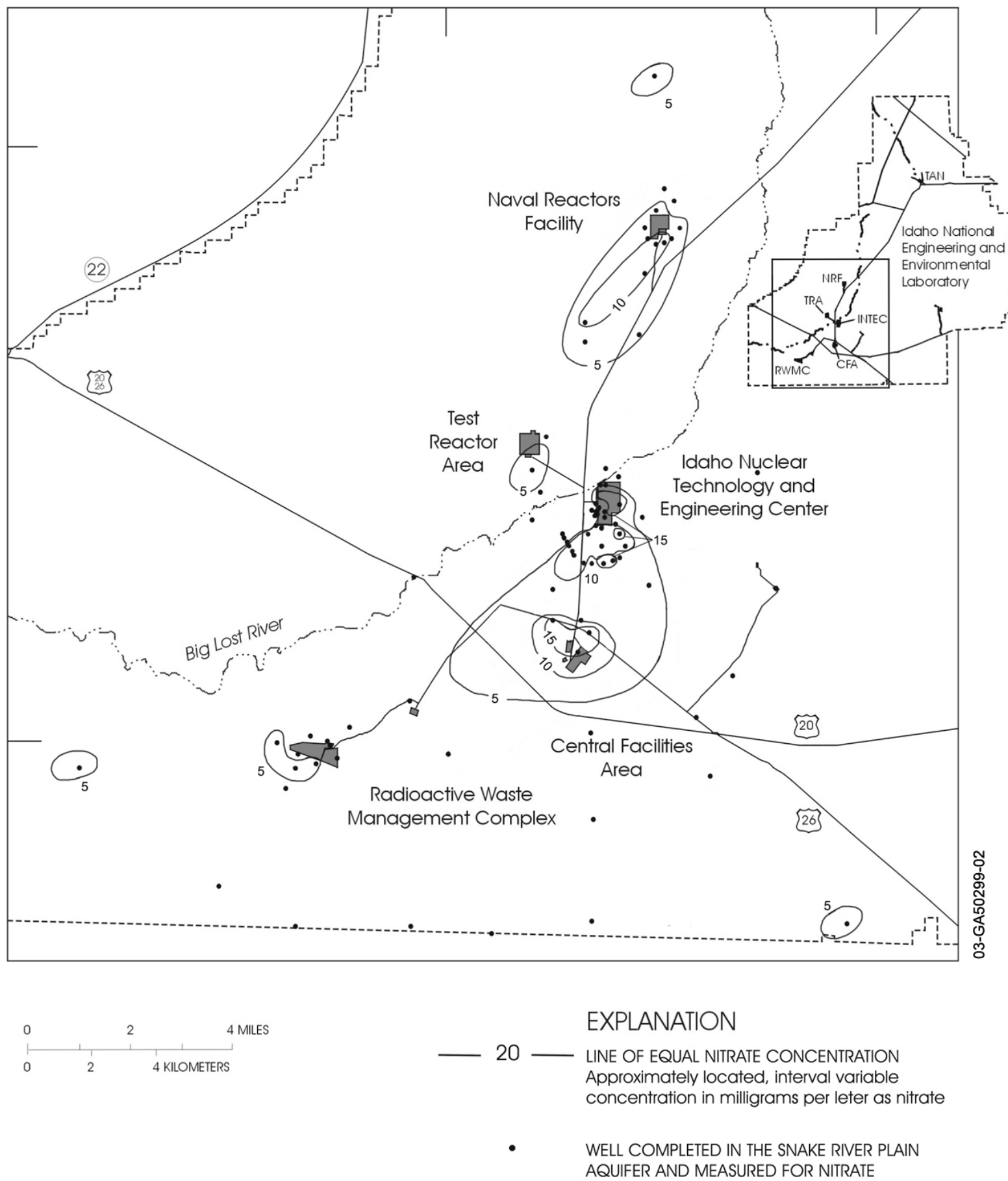

Figure 2-31. Distribution of nitrate in water from the Snake River Plain Aquifer in the south-central part of the INEEL, 1998 (Bartholomay 1998). 


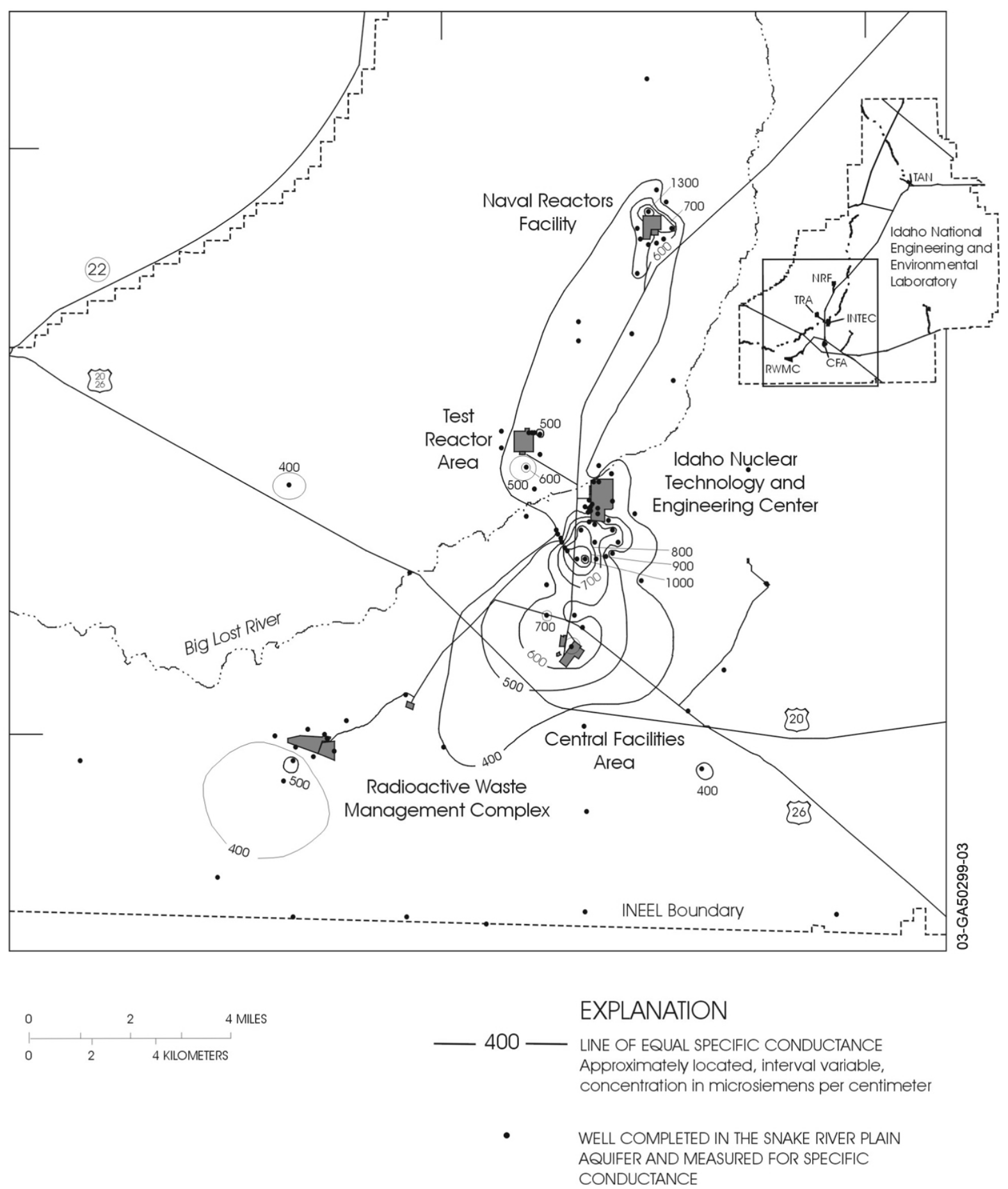

Figure 2-32. Distribution of specific conductance in water from the Snake River Plain Aquifer in the south-central part of the INEEL, 1998 (Bartholomay 1998). 

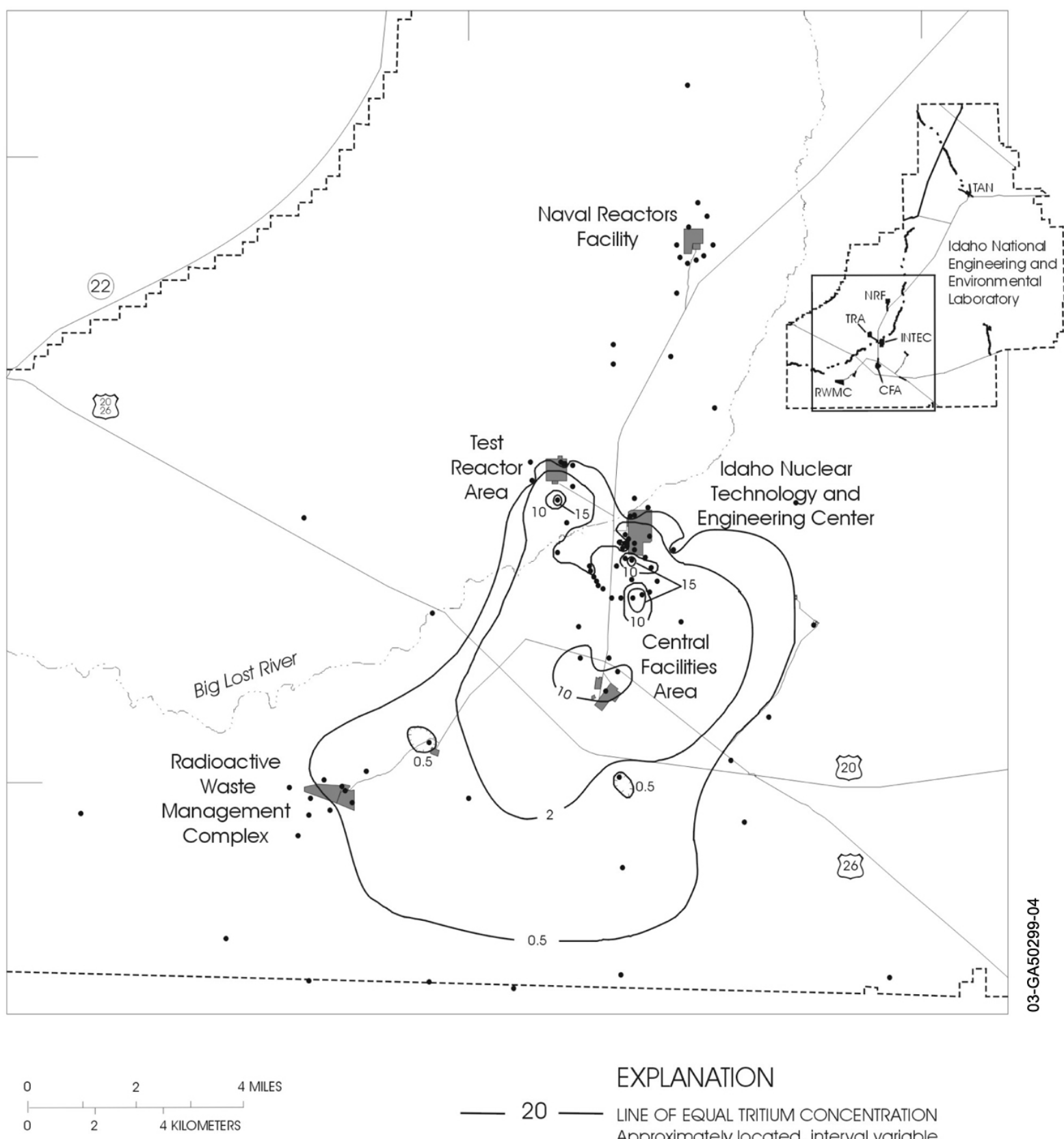

\section{EXPLANATION}

$20-$ LINE OF EQUAL TRITIUM CONCENTRATION Approximately located, interval variable, concentration in picocuries per milliliter

- Well completed in the SNAKE RIVER PLAin AQUIFER AND SAMPLED FOR TRITIUM

INDICATES THAT WATER FROM THE WELL HAS A TRITIUM
CONCENTRATION LESS THAN CONTOUR VALUE

Figure 2-33. Distribution of tritium in water from the Snake River Plain Aquifer in the south-central part of the INEEL, 1998 (Bartholomay 1998). 


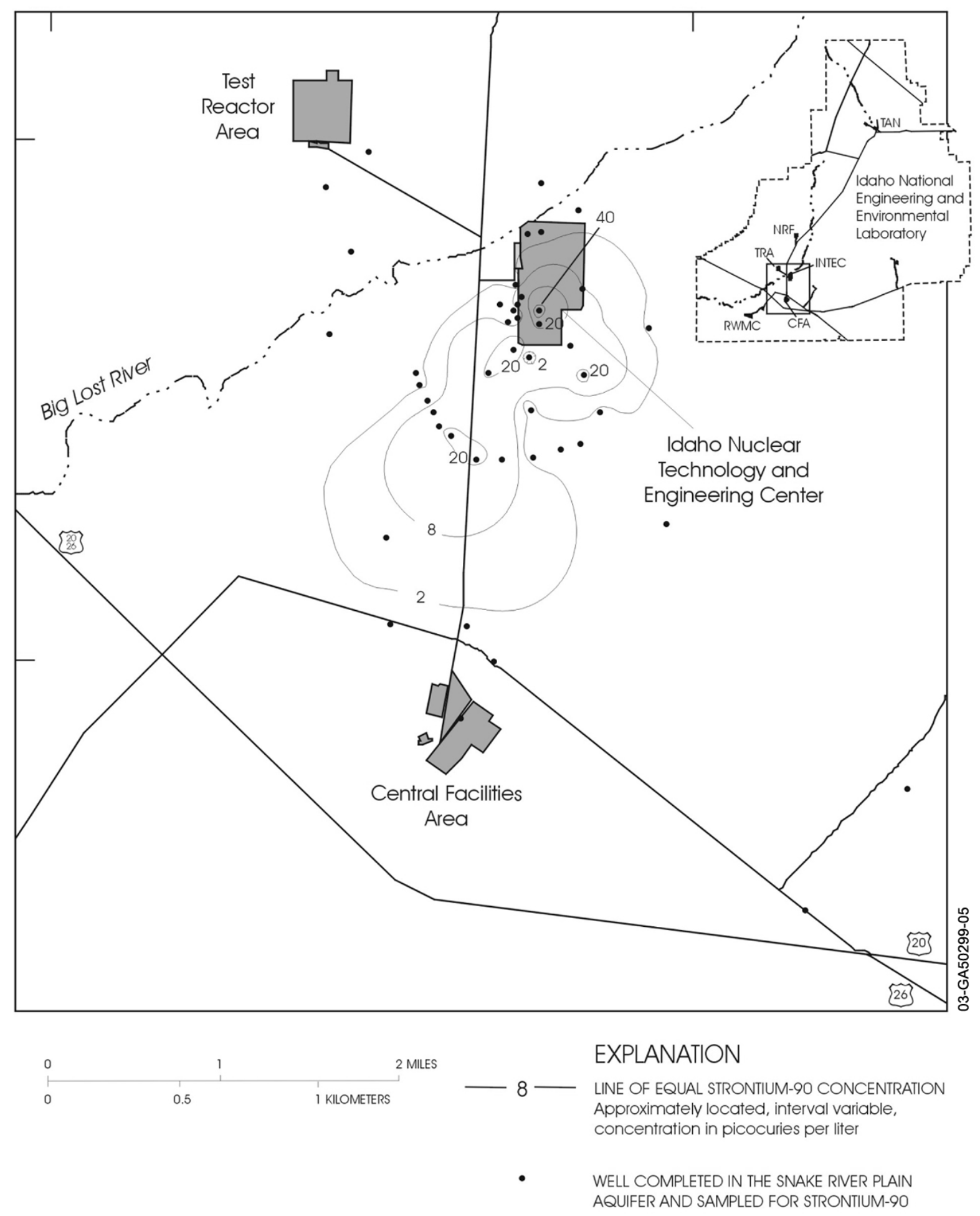

Figure 2-34. Distribution of strontium-90 in water from the Snake River Plain Aquifer in the south-central part of the INEEL, 1998 (Bartholomay 1998). 


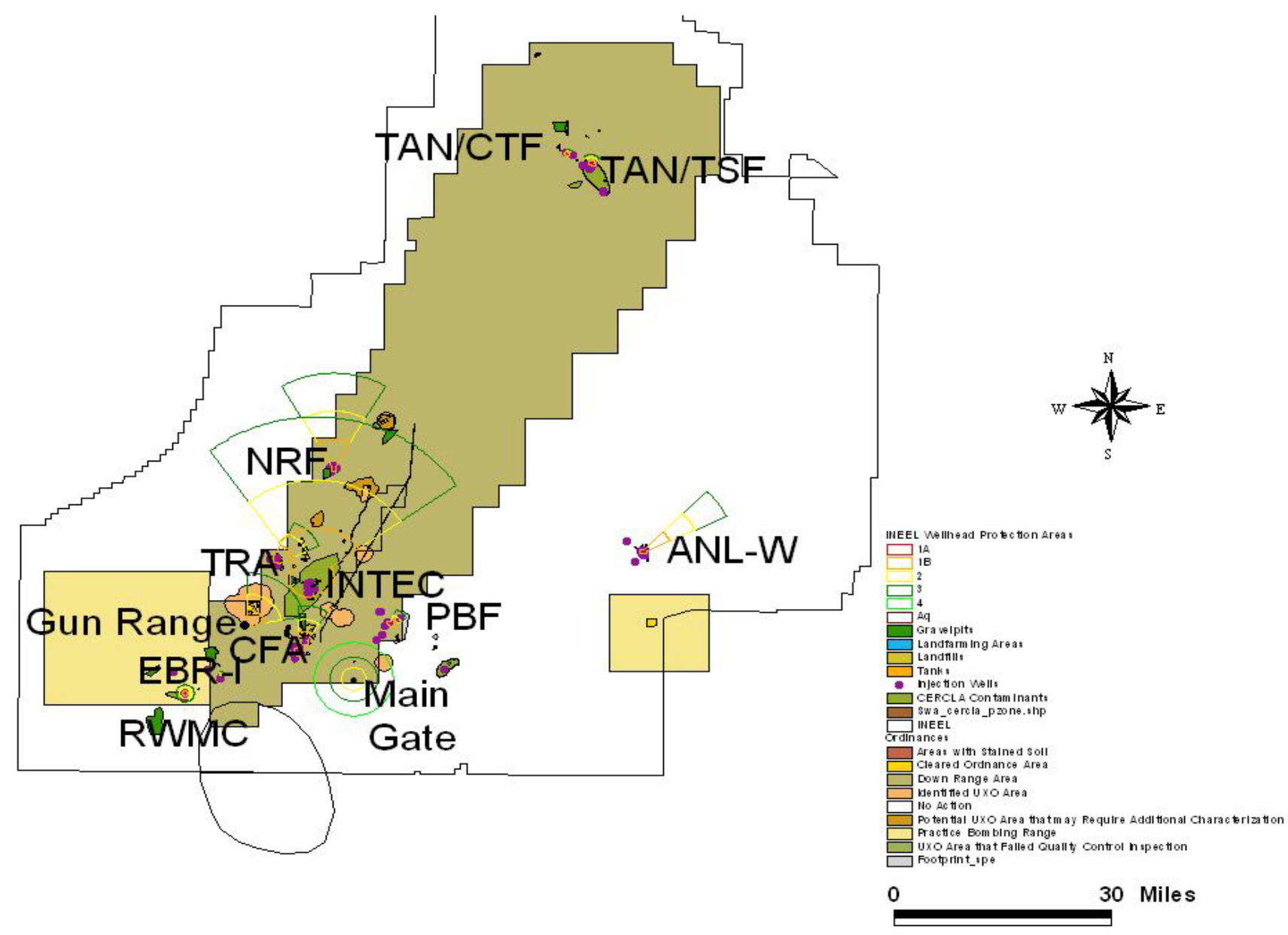

Figure 2-35. Distribution of soil and groundwater contaminants relative to wellhead protection areas at the INEEL. 


\section{SUSCEPTIBILITY ANALYSIS}

Susceptibility analyses under the State of Idaho's Source Water Assessment Program is a qualitative screening process that relies on the best available information, simplifying assumptions, and best professional judgment of those conducting the analyses. To compensate, the state has designed the process conservatively.

Within each delineated source water assessment area, each well is evaluated against hydrologic/hydrogeologic characteristics, land use characteristics, potentially significant contaminant sources, and the physical integrity of the wells or surface water intake. These assessments evaluate the physical systems and process that govern the movement of water ("hydrologic sensitivity") and contaminants ("susceptibility to potential contamination") through the system. The state defines hydrologic sensitivity as the movement of water through the subsurface without consideration of known or potential contaminants or their properties. The state defines susceptibility to potential contamination as the combined factors associated with hydrologic sensitivity, the potential sources of contamination, contaminant properties, and the properties of the drinking water system's intake.

All INEEL drinking water systems are supplied with groundwater from the eastern Snake River Plain Aquifer. Therefore, all susceptibility analyses require three evaluations:

- Hydrologic sensitivity

- $\quad$ Land-use and potential contaminant sources

- Well construction integrity.

The outcome of these evaluations is then summed for each system, and the results are normalized (DEQ 1999), to provide a final relative susceptibility rating of high, moderate, or low for each system. The susceptibility ratings are specific to a particular potential contaminant or category of potential contaminants, not to contaminants in general. However, despite the outcome of these analyses, if a synthetic chemical is detected in the drinking water source, the drinking water system is automatically given a high susceptibility rating for that particular chemical or chemical category. This is an important consideration since it is known that numerous radiological and chemical constituents that have been released or discharged by the INEEL have impacted the eastern Snake River Plain Aquifer.

\subsection{Hydrologic Sensitivity}

Determining the hydrologic sensitivity entails evaluating the movement of water through the subsurface without considering the potential contaminants or their properties (DEQ 1999). Each system's hydrologic sensitivity was estimated by evaluating the lithologic $\log (\mathrm{s})$ associated with the public water system's supply well(s). The specific information of interest for this evaluation is the type/soil drainage class for the surface soils and vadose materials, the depth to groundwater, and the presence or absence of significant aquitards between the ground surface and the well intake. The information gathered from the lithologic logs was evaluated against the criteria provided in Figure 3-1 (from DEQ 1999) to develop a numerical score for each system.

The INEEL requires as-built well diagrams to be developed for each well constructed on DOE property, or constructed under DOE funding, or as part of a DOE operation or activity. In cases where the borehole geology is logged during well construction, that information is also required to be included on the well's as-built drawing. Both the lithologic and well construction information are documented in the Comprehensive Well Survey files and database maintained in the INEEL Hydrogeological Data 


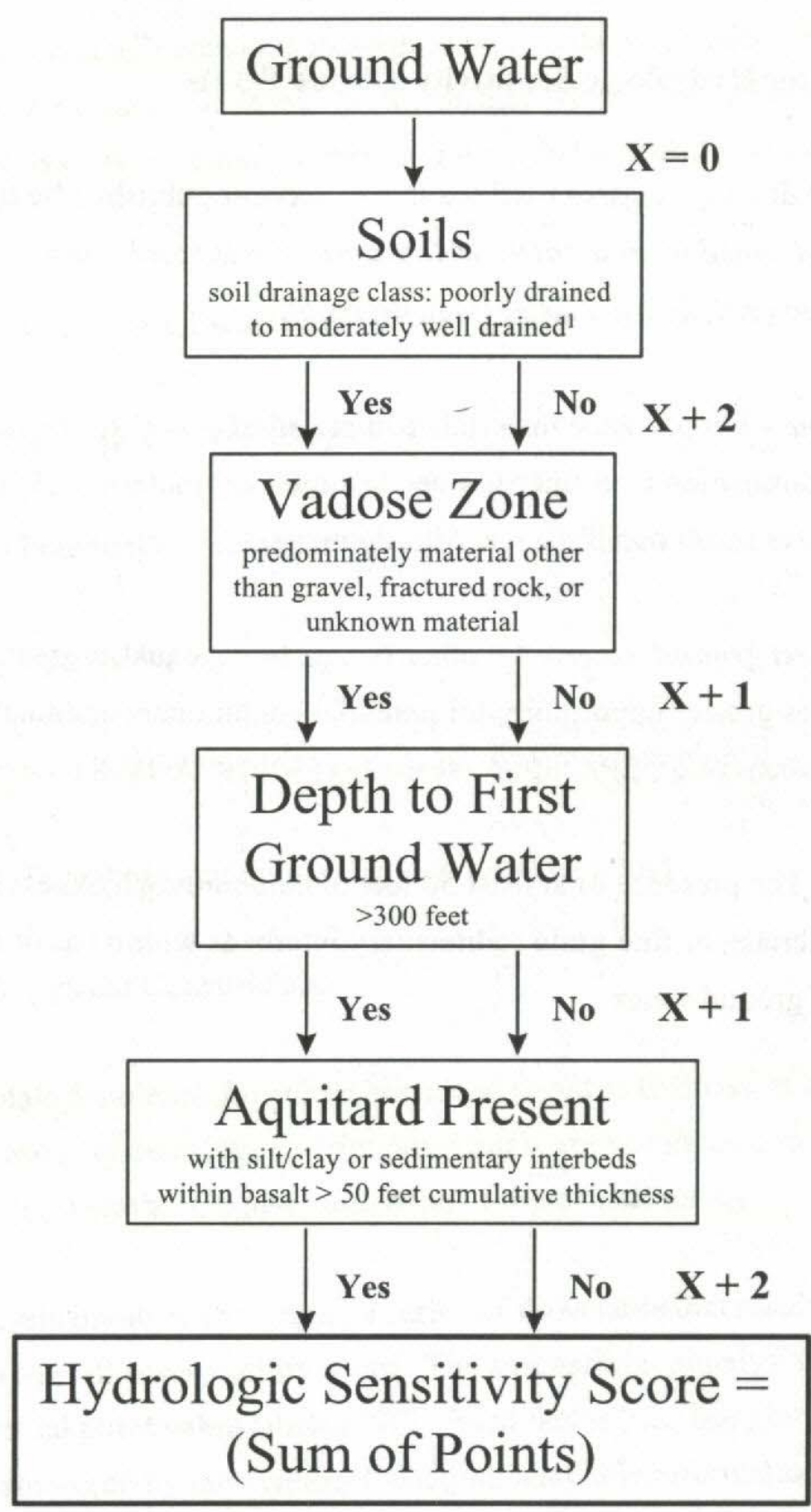

$$
\begin{aligned}
& 0 \text { or } 1=\text { Low Hydrologic Sensitivity Score } \\
& 2 \text { to } 4=\text { Moderate Hydrologic Sensitivity Score } \\
& 5 \text { or } 6=\text { High Hydrologic Sensitivity Score }
\end{aligned}
$$

${ }^{1}$ Terminology based on NRCS description of soil drainage classes for natural soil.

Figure 3-1. Hydrologic sensitivity assessment (from DEQ 1999). 
Repository. Appendix $\mathrm{C}$ includes as-built drawings for each of the wells associated with each of the INEEL public water systems. As-built drawings were located for each of the wells; however, lithologic logs are not available for wells CPP \#4, CPP \#5, the Gun Range, and TRA \#3. However, USGS-121 is located near CPP \#4 and \#5, so its lithologic information was used as a proxy for CPP \#4 and \#5.

Similarly, TRA \#4 is located near TRA \#5, so its lithologic information was used as a proxy for TRA \#3. However, no other well is located near the Gun Range, so the hydrologic sensitivity rating for this well was defaulted to the highest rating. The hydrologic sensitivity rating for each well is provided in Table 3-1. The analysis results indicate that most potable water wells at the INEEL are moderately-to-highly sensitive to potential contamination based on hydrologic sensitivity.

Table 3-1. Hydrologic sensitivity analysis of INEEL public water systems.

\begin{tabular}{|c|c|c|c|c|c|c|c|}
\hline & $\begin{array}{l}\text { Well } \\
\text { Name }\end{array}$ & $\begin{array}{l}\text { Building } \\
\text { Number }\end{array}$ & $\begin{array}{l}\text { Soil Type }^{\mathrm{a}} \\
(0 \text { or }+2)\end{array}$ & $\begin{array}{l}\text { Vadose Zone Type } \\
(0 \text { or }+1)\end{array}$ & $\begin{array}{l}\text { Depth to } \\
\text { Aquifer } \\
(0 \text { or }+1)\end{array}$ & $\begin{array}{l}\text { Aquitard }^{\mathrm{d}} \\
(0 \text { or }+2)\end{array}$ & $\begin{array}{l}\text { Sensitivity } \\
\text { (Total) }\end{array}$ \\
\hline ANL-W & EBR-II \#1 & ANL-W 754 & Silt/Clay (0) & Basalt/clay/cinders $(+1)$ & $630(0)$ & No $(+2)$ & Moderate (3) \\
\hline ANL-W & EBR-II \#2 & ANL-W 756 & Silt (0) & Basalt/clay/cinders $(+1)$ & $630(0)$ & No $(+2)$ & Moderate (3) \\
\hline CFA & CFA \#1 & CFA 651 & Alluvium $(+2)$ & Basalt/clay/ cinders $(+1)$ & $470(0)$ & Yes $(0)$ & Moderate (3) \\
\hline CFA & CFA \#2 & CFA 642 & Alluvium (+2) & Basalt/clay/cinders $(+1)$ & $470(0)$ & No $(+2)$ & $\operatorname{High}(5)$ \\
\hline EBR-I & EBR-I & EBR 711 & Silt (0) & Basalt/clay/cinders $(+1)$ & $600(0)$ & Yes $(0)$ & Low (1) \\
\hline Gun Range & Gun Range & B21-607 & Unknown $(+2)$ & Unknown $(+1)$ & $510(0)$ & $\begin{array}{l}\text { Unknown } \\
(+2)\end{array}$ & High (5) \\
\hline INTEC & $\mathrm{CPP} \# 4^{\mathrm{f}}$ & Near CPP 1767 & Alluvium $(+2)$ & Basalt/sand/gravel $(+1)$ & $440(0)$ & No $(+2)$ & High (5) \\
\hline INTEC & $\mathrm{CPP} \# 5^{\mathrm{f}}$ & Near CPP 1767 & Alluvium (+2) & Basalt/sand/gravel $(+1)$ & $440(0)$ & No $(+2)$ & High (5) \\
\hline $\begin{array}{l}\text { Main Gate } \\
\text { Facility }\end{array}$ & Main Gate & B27-605 & Alluvium $(+2)$ & Basalt/sediment $(+1)$ & $500(0)$ & No $(+2)$ & High (5) \\
\hline $\mathrm{NRF}$ & NRF-2 & NRF-612 & Gravel $(+2)$ & Basalt/clay $(+1)$ & $360(0)$ & No $(+2)$ & High (5) \\
\hline NRF & NRF-3 & NRF-622 & Gravel $(+2)$ & Basalt/cinders/sand $(+1)$ & $370(0)$ & No $(+2)$ & High (5) \\
\hline PBF & PBF \#1 & PER 602 & $\begin{array}{l}\text { Sand/Gravel } \\
(+2)\end{array}$ & $\begin{array}{l}\text { Basalt/cinders/clay /silt/ } \\
(+1)\end{array}$ & $460(0)$ & Yes $(0)$ & Moderate (3) \\
\hline PBF & PBF \#2 & PER 614 & $\begin{array}{l}\text { Sand/Gravel } \\
(+2)\end{array}$ & Basalt/clay/silt/ (+1) & $460(0)$ & Yes $(0)$ & Moderate (3) \\
\hline RWMC & RWMC & WMF 603 & Silty Sand (0) & $\begin{array}{l}\text { Basalt/cinders/silty sand } \\
(+1)\end{array}$ & $570(0)$ & No $(+2)$ & Moderate (3) \\
\hline TAN/CTF & CTF \#1 & TAN 632 & Sandy/Clay (0) & Basalt/clay/ cinders $(+1)$ & $200(+1)$ & Yes $(0)$ & Moderate (2) \\
\hline TAN/CTF & $\mathrm{CTF} \# 2$ & TAN 639 & Sandy/Clay $(0)$ & Basalt/clay/cinders $(+1)$ & $200(+1)$ & No $(+2)$ & Moderate (4) \\
\hline TAN/TSF & TSF \#1 & TAN 612 & Clay $(0)$ & Basalt/sand/ clay $(+1)$ & $210(+1)$ & $\mathrm{No}^{\mathrm{g}}(+2)$ & Moderate (4) \\
\hline TAN/TSF & TSF \#2 & TAN 613 & Clay (0) & Basalt $(+1)$ & $210(+1)$ & $\mathrm{No}^{\mathrm{g}}(+2)$ & Moderate (4) \\
\hline TRA & TRA \#1 & TRA 601 & Gravel $(+2)$ & Basalt/ cinders/ gravel $(+1)$ & $460(0)$ & No $(+2)$ & $\operatorname{High}(5)$ \\
\hline TRA & TRA $\# 3^{\mathrm{h}}$ & TRA 650 & $\begin{array}{l}\text { Sand/Gravel } \\
(+2)\end{array}$ & Basalt/cinders/sand $(+1)$ & $450(0)$ & No $(+2)$ & High (5) \\
\hline TRA & TRA \#4 & TRA 672 & $\begin{array}{l}\text { Sand/Gravel } \\
(+2)\end{array}$ & Basalt/cinders/sand $(+1)$ & $460(0)$ & No $(+2)$ & High (5) \\
\hline $\begin{array}{l}\text { a. Soil draina } \\
\text { b. Predominat } \\
\text { c. Greater tha } \\
\text { d. Silt/clay or } \\
\text { e. Low hydro } \\
\text { f. No litholog } \\
\text { g. No aquitarc } \\
\text { h. No litholog }\end{array}$ & $\begin{array}{l}\text { lass; poorly } \mathrm{dr} \\
\text { materials othe } \\
00 \mathrm{ft} \text {. } \\
\text { limentary inter } \\
\text { ic sensitivity ( } 0 \\
\mathrm{og} \text { is available } \\
50 \mathrm{ft} \text {, but the } \\
\log \text { is available }\end{array}$ & $\begin{array}{l}\text { to moderately well } \\
\text { gravel, fractured r } \\
\text { within basalt greate } \\
\text {; moderate hydrolo } \\
\text { ese wells, so this in } \\
\text { ial sediments consi } \\
\text { is well, so this info }\end{array}$ & $\begin{array}{l}\text { Irained based on NI } \\
\text { ck, or unknown mat } \\
\text { than } 50 \mathrm{ft} \text { in cumul } \\
\text { ic sensitivity ( } 2 \text { to } 4 \\
\text { ormation is based o } \\
\text { of } 50 \mathrm{ft} \text { of clay. } \\
\text { mation is based on }\end{array}$ & $\begin{array}{l}\text { S soil descriptions. } \\
\text { ial. } \\
\text { ive thickness. } \\
\text { and high hydrologic sensitivity } \\
\text { the information available at well } \\
\text { e information available at well TR }\end{array}$ & $\begin{array}{l}\text { or 6). } \\
\text { SGS-121. } \\
\# 4 .\end{array}$ & & \\
\hline
\end{tabular}




\subsection{Evaluation of Potential Contaminant Sources/Land Use}

The second evaluation identifies and evaluates the known and potential contaminants within the well capture zones delineated for each well. This includes determining the types of activities and the specific chemical, radiological, or biological contaminant(s) within the capture zone. For the purpose of conducting source water assessments, the State of Idaho assumes that urban areas and lands dominated by commercial or irrigated agricultural uses are more likely to have contaminants that may contaminate groundwater resources. In addition, the state assumes that areas of increased agricultural chemicals will experience an increased potential of contamination. Therefore, the state requires each system to determine if the above uses occur within the system's capture zones. In addition, the state requires each system to evaluate whether sources of SDWA-regulated volatile organic compounds (VOCs), synthetic organic compounds (SOCs), inorganic compounds (IOCs), radionuclides, or microbial contaminants (Figure 3-2) are present in the well capture zone. When conducting this analysis, the state requires that the documentation supporting the susceptibility analysis reference the specific potential contaminants or categories of potential contaminants on which the susceptibility rating is based.

No urban areas, irrigated agriculture, or commercial facilities or operations occur within the INEEL boundaries. However, numerous INEEL industrial-type facilities and activities use, treat, store, or dispose of chemical and radiological materials. Some of these facilities/activities are known or suspected to have released or discharged chemical and radioactive contaminants to the air, soil, or groundwater. These facilities and activities have been reviewed and documented by several organizations and programs at the INEEL. Those facilities and activities that are considered known or potential risks to groundwater resources are discussed in the following paragraphs.

Unlike many public water systems that are conducting source water assessments for the first time, the INEEL has been evaluating the potential impacts of known and suspected contaminants on local and regional water resources for many years. Numerous analogous evaluations have been conducted to meet both regulatory requirements (e.g., RCRA, CERCLA and NRC siting, monitoring, and cleanup requirements) and to meet DOE operational and administrative requirements. These evaluations include those conducted via the INEL Groundwater Monitoring Plan (DOE/ID-10441 1993), which evaluated all known historical operations and activities at the INEEL to determine their potential for contaminating groundwater. This plan was updated in 2002 (DOE-ID 11034). Ongoing evaluations of known and potential contaminant releases and their impact on the environment, including groundwater resources, have been conducted by the INEEL via the INEEL Federal Facilities Agreement Compliance Order, which is jointly managed by the DOE, EPA, and the State of Idaho. These evaluations served as the primary sources for establishing a list of known/potential contaminants at the INEEL. In addition, the USGS conducted baseline hydrogeological characterizations prior to any operations at the INEEL, and the USGS has continued to monitor and evaluate the impacts of INEEL facilities and operations on local/regional water resources since then. Finally, numerous INEEL organizations maintain contaminant-related information in INEEL Geospatial Laboratory databases. These databases were reviewed for the relevant sources of information. Therefore, the known and potential sources of contaminants that may impact INEEL drinking water supplies are well understood.

All major known/potential sources of contamination, that is those that were determined to be a potentially significant source of groundwater contamination, were described in Section 2.2.2 and mapped in a GIS layer. This information, the information from the various INEEL Geospatial Laboratory databases, and the wellhead protection area information was intersected using GIS technology. All significant known/potential contaminant sources located in the wellhead protection areas were then documented in Appendix B. The facility-specific/release-specific information was then evaluated against the criteria in Figure 3-2, and Tables 3-2 and 3-3, and the results are provided in Table 3-4. 
In addition, a brief evaluation was conducted of ongoing pesticide uses at the INEEL. Although herbicides, insecticides, and fungicides are used at the INEEL, they are strictly regulated and monitored. The INEEL's pesticide policy is documented in Section 4.46, "Procuring, Applying and Storing Pesticides," of Management Control Procedure (MCP)-3480. The INEEL does not allow the use of EPA "restricted" pesticides. Of the pesticides regulated under the Safe Drinking Water Act (Table 3-2), the INEEL typically only uses 2,4-D and Glyphosate. All INEEL applicators are licensed by the State of Idaho. They are required to apply all pesticides in accordance with the product/manufacturers label. Pesticide applications are banned in the 50-foot wellhead sanitary setback, and internal requirements restrict the application of pesticides when conditions may cause pesticide drift or runoff. These factors, in addition to the site-specific geologic/hydrologic conditions (e.g., low precipitation and a thick vadose zone), make it highly unlikely that pesticide use at the INEEL will become a source of groundwater contamination and are not considered further in the following sections.

\subsection{Evaluation of System Construction}

In accordance with INEEL policy, all wells at the INEEL are required to meet the minimum requirements in the State of Idaho's Well Construction Standards Rules (IDAPA 37.03.09). Since some INEEL wells were constructed before promulgation of these rules, the INEEL conducted a comprehensive INEEL-wide evaluation of all wells constructed before 1993. These evaluations were documented in the Comprehensive Well Survey for the Idaho National Engineering Laboratory (DOE/ID-10402 1993), which is updated annually. This information, maintained in the INEEL Hydrogeologic Data Repository, was the basis for the system construction evaluation. The well construction information was evaluated against the criteria in Figure 3-3, and the results are summarized in Table 3-5.

\subsection{Contaminants of Interest Detected In INEEL Public Water Systems}

Despite the results of the hydrologic sensitivity, contaminant sources/land uses and construction evaluations, DEQ stated that if a synthetic chemical is detected in the drinking water source, the drinking water system is automatically given a high susceptibility rating for that particular chemical or chemical category. This is an important consideration at the INEEL because water quality in the eastern Snake River Plain Aquifer is known to have been impacted by past and ongoing INEEL operations and activities.

The past 5 years (1997-2001) of INEEL drinking water monitoring results were reviewed to determine if any synthetic constitutes were detected or if any maximum contaminant levels were exceeded in any of the INEEL's public water systems. Table 3-6 summarizes the contaminants detected in drinking water samples at the INEEL that have either exceeded their regulatory threshold or are at a high enough concentration to justify additional scrutiny.

Of the constituents detected in the INEEL's drinking water systems, only coliform bacteria and trichloroethylene exceeded the regulatory threshold during this period. Coliform bacteria exceeded its MCL once each in the INTEC, NRF, TRA, and RWMC distribution systems. Trichloroethylene exceeded its MCL in the TAN/TSF Well \#1; however, its concentration is now below the MCL at the point of compliance and it has remained steady. Although the concentrations of carbon tetrachloride have not exceeded the MCL at the RWMC, the concentrations in the well have come close to the MCL. However, the wellhead is not the point of compliance for the Safe Drinking Water Act; therefore, this is not a regulatory issue, but since its concentration is high at the wellhead and it continues to trend upward, it is being watched closely. Although the coliform bacteria issues are probably isolated incidents, the trichloroethylene issue at TAN and the carbon tetrachloride issue at the RWMC are being actively 
addressed by the INEEL's ongoing CERCLA program. These issues will also be addressed by the INEEL's Source Water Management Plan, which will be developed in FY 2003.

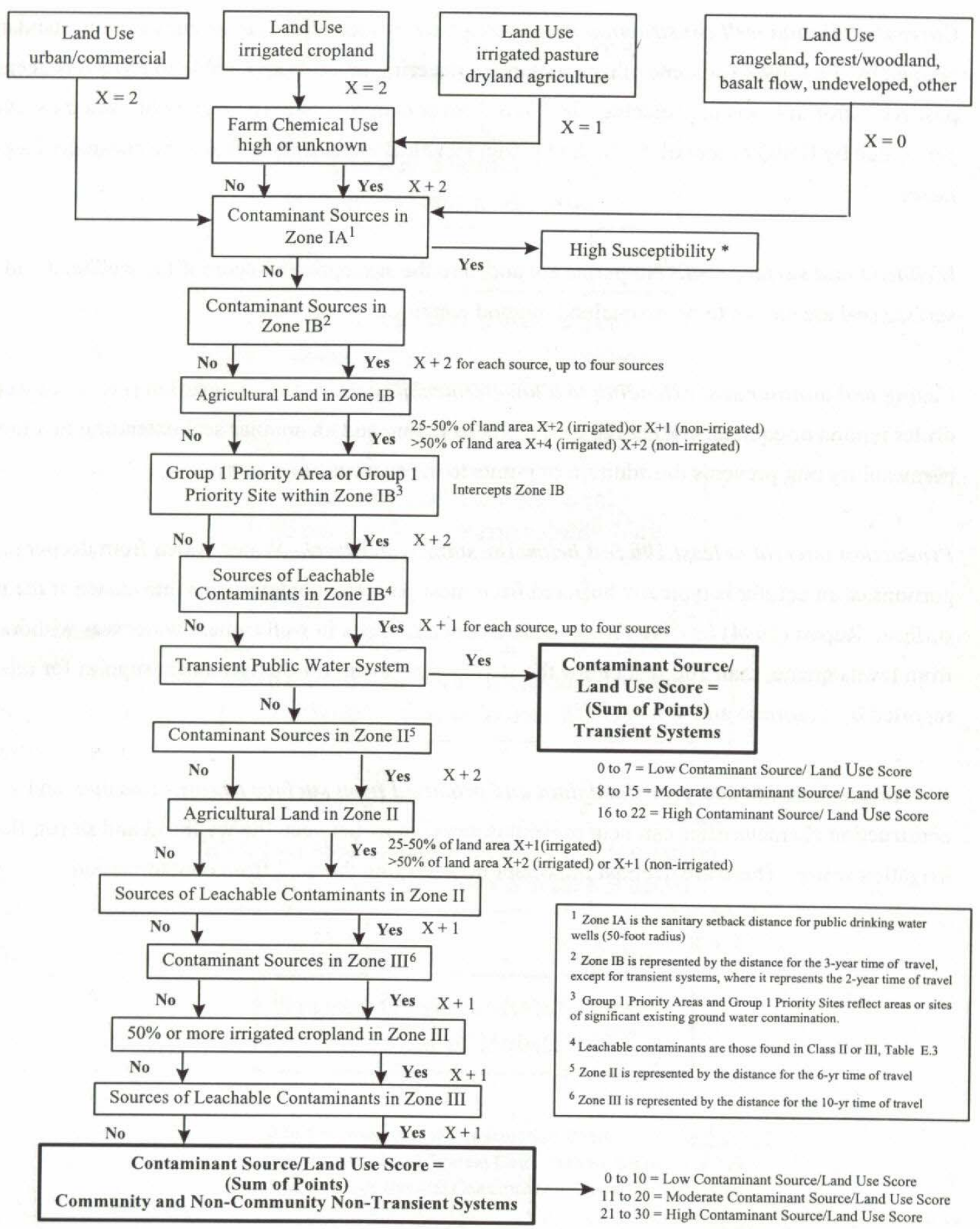

*Public water systems may petition IDEQ to revise susceptibility rating based on elimination of contaminant sources or other site-specific factors.

Figure 3-2. Contaminant/land use analysis (from DEQ 1999). 
Table 3-2. State of Idaho contaminant categories (from DEQ 1999).

\begin{tabular}{|c|c|c|c|c|}
\hline $\begin{array}{c}\text { Volatile Organic } \\
\text { Compound } \\
\text { Contaminants } \\
\end{array}$ & $\begin{array}{c}\text { Synthetic Organic Compound } \\
\text { Contaminants }\end{array}$ & Radionuclides & $\begin{array}{c}\text { Inorganic } \\
\text { Compound } \\
\text { Contaminants } \\
\end{array}$ & $\begin{array}{c}\text { Microbial } \\
\text { Contaminants }\end{array}$ \\
\hline 1,2,4-trichlorobenzene & 2,4-D (2,4-dichlorophenoxyacetic & Combined beta/photon & Asbestos & \multirow{32}{*}{$\begin{array}{l}\text { Cryptosporidium } \\
\text { Total coliform } \\
\text { bacteria }\end{array}$} \\
\hline 1,1-dichloroethylene & acid) & emitters & Barium & \\
\hline 1,1,2-trichloroethane & $\begin{array}{l}2,4,5-\mathrm{TP}(2,4,5- \\
\text { trichlorophenoxypropanic acid) or }\end{array}$ & $\begin{array}{l}\text { Combined radium-226 } \\
\text { and radium- } 228\end{array}$ & Cadmium & \\
\hline 1,2-dichloroethane & (Silvex) & & Chromium & \\
\hline 1,2-dichloropropane & 2,3,7,8-tetrachlorodibenzodioxin & activity & Copper & \\
\hline 1,1,1-trichloroethane & (dioxin) & Strontium-90 & Cyanide & \\
\hline Benzene & Alachlor & Tritium & Fluoride & \\
\hline Bromodichloromethane & Atrazine & & Lead & \\
\hline Bromoform & Benzo (a) pyrene & & Mercury & \\
\hline Carbon tetrachloride & Carbofuran & & Nickel & \\
\hline Chlorodibromomethane & Chlordane & & Nitrate & \\
\hline Chloroform & Dalapon & & Thallium & \\
\hline cis-1,2- & Di(2-ethylhexyl)adipate & & & \\
\hline dichloroethylene & Di(2-ethylhexyl)phthalate & & & \\
\hline Dibromochloropropane & Diquat & & & \\
\hline Dichlorobenzene o- & Dinoseb & & & \\
\hline (1,2-dichlorobenzene) & Endothall & & & \\
\hline $\begin{array}{l}\text { Dichlorobenzene p- } \\
\text { (1,4-dichlorobenzene) }\end{array}$ & Endrin & & & \\
\hline Dichlorobenzene m- & Ethylene dibromide (EDB) & & & \\
\hline (1,3-dichlorobenzene) & Glyphosate & & & \\
\hline Dichloromethane & Heptachlor & & & \\
\hline Ethylbenzene & Heptachlor epoxide & & & \\
\hline Ethylene dibromide & Heptachlor & & & \\
\hline$(\mathrm{EDB})$ & Hexachlorobenzene & & & \\
\hline Monochlorobenzene & Hexachlorocyclopentadiene & & & \\
\hline Styrene & Linden & & & \\
\hline Tetrachloroethylene & Methoxychlor & & & \\
\hline Toluene & Oxamyl (Vydate) & & & \\
\hline $\begin{array}{l}\text { trans-1,2- } \\
\text { dichloroethylene }\end{array}$ & Pentachlorophenol (penta) & & & \\
\hline aichioroetnyiene & Picloram & & & \\
\hline Vinul bloride & Simazine & & & \\
\hline Xylenes (total) & Toxaphene & & & \\
\hline
\end{tabular}


Table 3-3. State of Idaho contaminant leachability classes ${ }^{\mathrm{a}}$ (from DEQ 1999).

\begin{tabular}{|c|c|c|}
\hline Class I & Class II & Class III \\
\hline 1,1,1-trichloroethane $(1,1,1-\mathrm{TCA})$ & 1,1-dichloroethylene (1,1-DCE) & 1,2-dichloroethane (1,2-DCA) \\
\hline 1,2-dichlorobenzene (o-...) & \multirow{2}{*}{$\begin{array}{l}\text { 1,2-dibromo-3-chloropropane } \\
\text { (DBCP) }\end{array}$} & bis2-ethylhexyl) adipate ${ }^{b}$ \\
\hline 1,2,4-trichlorobenzene & & Dalapon $^{\mathrm{b}}$ \\
\hline 1,3-dichlorobenzene (m-...) & 1,2-dibromoethane (EDB) & Dichloromethane (DCM) \\
\hline 1,4-dichlorobenzene (p-...) & 1,2-dichloropropane & Dinoseb \\
\hline 2,3,7,8-tetrachlorodibenzodioxin & \multirow{2}{*}{$\begin{array}{l}\text { Benzene } \\
\text { Bromodichloromethane (THM) }\end{array}$} & Antimony \\
\hline (Dioxin) & & Asbestos \\
\hline Benzo[a]pyrene (PAH) & \multirow{3}{*}{$\begin{array}{l}\text { Chloroform (THM) } \\
\text { cis-1,2-dichloroethylene (c-1,2- } \\
\text { DCE) }\end{array}$} & Beryllium \\
\hline bis(2-ethylhexyl) phthalate & & \\
\hline Carbon tetrachloride & & riuoride \\
\hline Chlorobenzene & \multirow{3}{*}{$\begin{array}{l}\text { Lead } \\
\text { Vinyl chloride }\end{array}$} & Nickel \\
\hline 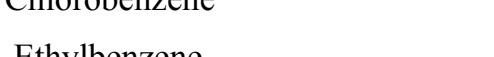 & & Mercury \\
\hline Ethylbenzene & & Nitrite \\
\hline \multicolumn{2}{|l|}{ Heptachlor epoxide } & Selenium \\
\hline \multicolumn{2}{|l|}{ PCBs (as decachlorobiphenyl) } & Thallium \\
\hline \multicolumn{2}{|l|}{ Pentachlorophenol } & Gross alpha particle activity \\
\hline \multicolumn{2}{|l|}{ Styrene } & Combined beta/photon/emitters \\
\hline \multicolumn{2}{|l|}{ Tetrachloroethylene (PCE) } & Combined radium-226 and \\
\hline \multicolumn{2}{|l|}{ Toluene } & radium-228 \\
\hline \multicolumn{2}{|l|}{ Toxaphene } & Strontium-90 \\
\hline \multicolumn{2}{|l|}{ Trichloroethylene (TCE) } & Tritium \\
\hline \multicolumn{3}{|l|}{ Xylenes, total } \\
\hline \multicolumn{3}{|l|}{ Total coliform bacteria } \\
\hline \multicolumn{3}{|l|}{ Cryptosporidium } \\
\hline \multicolumn{3}{|c|}{$\begin{array}{l}\text { a. This table presents only a relative comparison of leachability. It reflects a simplistic characterization of leachability that does not take into } \\
\text { account many environmental factors that control leachability, such as the percentage of organic material and clay in the subsurface. }\end{array}$} \\
\hline \multicolumn{3}{|c|}{ b. Organic contaminants for which the leachability model could not be used due to insufficient information. } \\
\hline
\end{tabular}


Table 3-4. INEEL groundwater potential contaminant ${ }^{\mathrm{a}}$ sources/land use analysis.

\begin{tabular}{|c|c|c|c|c|c|c|c|c|c|c|c|c|}
\hline Facility & Well Name & $\begin{array}{l}\text { Land Use } \\
\text { Industrial? } \\
\quad(\mathrm{X}+2)\end{array}$ & $\begin{array}{c}\text { Sources }^{\mathrm{b}} \\
\text { in Zone } \\
\text { IA? }\end{array}$ & $\begin{array}{l}\text { Sources }{ }^{ } \text {in } \\
\text { Zone IB? } \\
(\mathrm{X}+2 \text { to } 8)\end{array}$ & $\begin{array}{l}\text { Group } 1^{\mathrm{d}} \\
\text { Priority } \\
\text { Area/Site in } \\
\text { Zone IB? } \\
(\mathrm{X}+2)\end{array}$ & $\begin{array}{c}\text { Leachable }^{\mathrm{e}} \\
\text { Contaminants } \\
\text { in Zone IB? } \\
(\mathrm{X}+1 \text { to } 4)\end{array}$ & $\begin{array}{c}\text { Transient }{ }^{\mathrm{f}} \\
\text { Public Water } \\
\text { System? } \\
\text { (Total) } \\
\end{array}$ & $\begin{array}{c}\text { Sources }^{\mathrm{g}} \\
\text { in Zone II } \\
(\mathrm{X}+2) \\
\end{array}$ & $\begin{array}{c}\text { Leachable }^{\mathrm{h}} \\
\text { Contaminants } \\
\text { in Zone II? } \\
(\mathrm{X}+1)\end{array}$ & $\begin{array}{c}\text { Sources in } \\
\text { Zone III } \\
(\mathrm{X}+1)\end{array}$ & $\begin{array}{c}\text { Leachable }^{\mathrm{j}} \\
\text { Contaminants } \\
\text { in Zone III? } \\
(\mathrm{X}+1)\end{array}$ & $\begin{array}{c}\text { Contaminant }{ }^{\mathrm{k}} / \\
\text { Land Use Score } \\
\text { (Total) }\end{array}$ \\
\hline ANL-W & EBR-II \#1 & Yes (2) & No (0) & Yes (8) & 0 & Yes (4) & No & No $(0)$ & No $(0)$ & No $(0)$ & No $(0)$ & Med. (14) \\
\hline ANL-W & EBR-II \#2 & Yes (2) & Yes $^{\mathrm{m}}$ & Yes (8) & 0 & Yes (4) & No & No $(0)$ & No $(0)$ & No $(0)$ & No $(0)$ & $\operatorname{High}^{\mathrm{m}}$ \\
\hline CFA & CFA \#1 & Yes (2) & Yes $^{\mathrm{m}}$ & Yes (8) & 0 & Yes (4) & No & Yes (2) & Yes (1) & Yes (1) & Yes (1) & $\operatorname{High}^{\mathrm{m}}$ \\
\hline CFA & CFA \#2 & Yes (2) & Yes $^{\mathrm{m}}$ & Yes (8) & 0 & Yes (4) & No & Yes (2) & Yes (1) & Yes (1) & Yes (1) & $\mathrm{High}^{\mathrm{m}}$ \\
\hline EBR-1 & EBR-1 & No $(0)$ & No $(0)$ & No $(0)$ & 0 & No $(0)$ & $\mathrm{Yes}^{\mathrm{m}}$ & & & & & Low (0) \\
\hline Gun Range & Gun Range & No $(0)$ & No $(0)$ & No $(0)$ & 0 & No $(0)$ & $\mathrm{Yes}^{\mathrm{m}}$ & & & & & Low (0) \\
\hline INTEC & СРP \#4 & Yes (2) & Yes $^{\mathrm{m}}$ & Yes (8) & 0 & Yes (4) & No & No $(0)$ & No $(0)$ & Yes (1) & Yes (1) & $\operatorname{High}^{\mathrm{m}}$ \\
\hline INTEC & CPP \#5 & Yes (2) & Yes $^{\mathrm{m}}$ & Yes (8) & 0 & Yes (4) & No & No $(0)$ & No $(0)$ & Yes (1) & Yes (1) & $\operatorname{High}^{\mathrm{m}}$ \\
\hline Main Gate & Main Gate & No $(0)$ & No $(0)$ & No $(0)$ & 0 & No $(0)$ & Yes $^{\mathrm{m}}$ & & & & & Low (0) \\
\hline NRF & NRF-2 & Yes (2) & Yes $^{\mathrm{m}}$ & Yes (4) & 0 & Yes (1) & No & No $(0)$ & No $(0)$ & No $(0)$ & No $(0)$ & $\operatorname{High}^{\mathrm{m}}$ \\
\hline NRF & NRF-3 & Yes (2) & Yes $^{\mathrm{m}}$ & Yes (4) & 0 & Yes (1) & No & No $(0)$ & No $(0)$ & No $(0)$ & No $(0)$ & $\mathrm{High}^{\mathrm{m}}$ \\
\hline PBF & $\mathrm{PBF} \# 1$ & Yes (2) & No $(0)$ & Yes (4) & 0 & Yes (2) & No & Yes (2) & Yes (1) & Yes (1) & Yes (1) & Med. (13) \\
\hline PBF & PBF \#2 & Yes (2) & No $(0)$ & Yes (4) & 0 & Yes (2) & No & Yes (2) & Yes (1) & Yes (1) & Yes (1) & Med. (13) \\
\hline RWMC & RWMC & Yes (2) & Yes $^{\mathrm{m}}$ & Yes (2) & 0 & Yes (1) & No & & Yes (1) & Yes (1) & Yes (1) & $\operatorname{High}^{\mathrm{m}}$ \\
\hline TAN/CTF & CTF \#1 & Yes (2) & No $(0)$ & No $(0)$ & 0 & No $(0)$ & No & No $(0)$ & No $(0)$ & No $(0)$ & No $(0)$ & Low (2) \\
\hline TAN/CTF & CTF \#2 & Yes (2) & No $(0)$ & No $(0)$ & 0 & No $(0)$ & No & No $(0)$ & No $(0)$ & No $(0)$ & No $(0)$ & Low (2) \\
\hline TAN/TSF & TSF \#1 & Yes (2) & Yes $^{\mathrm{m}}$ & Yes (8) & 0 & Yes (4) & No & Yes (2) & Yes (1) & Yes (1) & Yes (1) & $\operatorname{High}^{\mathrm{m}}$ \\
\hline TAN/TSF & TSF \#2 & Yes (2) & Yes $^{\mathrm{m}}$ & Yes (8) & 0 & Yes (4) & No & Yes (2) & Yes (1) & Yes (1) & Yes (1) & $\operatorname{High}^{\mathrm{m}}$ \\
\hline TRA & TRA \#1 & Yes (2) & Yes $^{\mathrm{m}}$ & Yes (8) & 0 & Yes (4) & No & No $(0)$ & No (0) & No $(0)$ & No $(0)$ & $\operatorname{High}^{\mathrm{m}}$ \\
\hline
\end{tabular}


Table 3-4. (continued).

\begin{tabular}{|c|c|c|c|c|c|c|c|c|c|c|c|c|}
\hline Facility & Well Name & $\begin{array}{l}\text { Land Use } \\
\text { Industrial? } \\
\quad(\mathrm{X}+2)\end{array}$ & $\begin{array}{c}\text { Sources }^{\mathrm{b}} \\
\text { in Zone } \\
\text { IA? }\end{array}$ & $\begin{array}{l}\text { Sources }^{\mathrm{c}} \text { in } \\
\text { Zone IB? } \\
(\mathrm{X}+2 \text { to } 8)\end{array}$ & $\begin{array}{l}\text { Group } 1^{\mathrm{d}} \\
\text { Priority } \\
\text { Area/Site in } \\
\text { Zone IB? } \\
(\mathrm{X}+2)\end{array}$ & $\begin{array}{c}\text { Leachable }^{\mathrm{e}} \\
\text { Contaminants } \\
\text { in Zone IB? } \\
(\mathrm{X}+1 \text { to } 4)\end{array}$ & $\begin{array}{l}\text { Transient }^{\mathrm{f}} \\
\text { Public Water } \\
\text { System? } \\
\text { (Total) } \\
\end{array}$ & $\begin{array}{l}\text { Sources }^{\mathrm{g}} \\
\text { in Zone II } \\
(\mathrm{X}+2)\end{array}$ & $\begin{array}{c}\text { Leachable }^{\mathrm{h}} \\
\text { Contaminants } \\
\text { in Zone II? } \\
(\mathrm{X}+1)\end{array}$ & $\begin{array}{c}\text { Sources in } \\
\text { Zone III } \\
(\mathrm{X}+1)\end{array}$ & $\begin{array}{c}\text { Leachable }^{\mathrm{j}} \\
\text { Contaminants } \\
\text { in Zone III? } \\
(\mathrm{X}+1)\end{array}$ & $\begin{array}{c}\text { Contaminant } \mathrm{t}^{\mathrm{k}} / \\
\text { Land Use Score } \\
\text { (Total) }\end{array}$ \\
\hline TRA & TRA \#3 & Yes (2) & Yes $^{\mathrm{m}}$ & Yes (8) & 0 & Yes (4) & No & No $(0)$ & No $(0)$ & No $(0)$ & No $(0)$ & $\operatorname{High}^{\mathrm{m}}$ \\
\hline TRA & TRA \#4 & Yes (2) & Yes $^{\mathrm{m}}$ & Yes (8) & 0 & Yes (4) & No & No $(0)$ & No $(0)$ & No $(0)$ & No (0) & $\operatorname{High}^{\mathrm{m}}$ \\
\hline
\end{tabular}

a. Contaminants are listed by facility in Appendix B.

b. If contaminant sources are found in Zone IA or "synthetic compounds" are found in source water, the score automatically defaults to high susceptibility. ANL: an industrial waste pond ditch in EBR-II \#2;

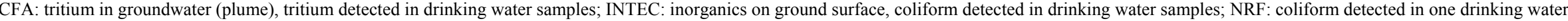
sample; RWMC: coliform, TCE, and carbon tetrachloride detected in drinking water samples; TAN/TSF: TCE detected in drinking water samples; TRA: coliform detected in drinking water samples.

c. If contaminant sources are found in Zone IB, add two points $(\mathrm{X}+2)$ for each source up to four total sources.

d. If a Group I Priority Area/Site is in Zone IB, add two points $(X+2)$.

e. If leachable contaminants are in Zone IB, add one point $(\mathrm{X}+1)$ for each source for up to four sources.

f. If a transient public water system, sum up points for total score. EBR-I, Gun Range, and Main Gate wells are transient, noncommunity water systems.

g. If contaminant sources are found in Zone II, add two points $(\mathrm{X}+2)$.

h. If leachable contaminants are in Zone II, add one point $(\mathrm{X}+1)$ for each source.

i. If contaminants are in Zone III, add one point $(\mathrm{X}+1)$ for each source.

○ j. If leachable contaminants are in Zone III, add one point $(\mathrm{X}+1)$ for each source.

k. $0-10=$ Low; $11-20=$ Medium; $21-30=$ High Contaminant Source/Land Use Score

$\mathrm{m}$. Point at which this evaluation was discontinued because criteria defaulted the well to a "high" score. 
Table 3-5. INEEL drinking water well construction evaluation.

\begin{tabular}{|c|c|c|c|c|c|c|c|}
\hline Facility & $\begin{array}{l}\text { Well }^{\mathrm{a}} \\
\text { Name }\end{array}$ & $\begin{array}{l}\text { Meets Idaho } \\
\text { Well } \\
\text { Construction } \\
\text { Standards? }^{\mathrm{b}} \\
(\mathrm{X}+1)\end{array}$ & $\begin{array}{c}\text { Wellhead }^{\mathrm{c}, \mathrm{d}} \text { and } \\
\text { Surface Seal in } \\
\text { Good Condition? } \\
(\mathrm{X}+1)\end{array}$ & $\begin{array}{c}\text { Casing }^{\mathrm{c}, \mathrm{d}} \text { and } \\
\text { Annular Seal } \\
\text { Extend to Low } \\
\text { Permeability } \\
\text { Unit? } \\
(\mathrm{X}+2)\end{array}$ & $\begin{array}{c}\text { Well Intake } \geq 100 \\
\text { Feet Below Static } \\
\text { Water Level? } \\
(\mathrm{X}+1)\end{array}$ & $\begin{array}{l}\text { Wellhead is } \\
\text { Protected from } \\
\text { Flooding? } \\
(\mathrm{X}+1)\end{array}$ & $\begin{array}{c}\text { System }^{\mathrm{f}} \\
\text { Construction Score } \\
\text { (Total) }\end{array}$ \\
\hline ANL-W & EBR-II \#1 & No $(+1)$ & No $(+1)$ & $\mathrm{No}^{\mathrm{g}}(+2)$ & No $(+1)$ & Yes & $\operatorname{High}(5)$ \\
\hline ANL-W & EBR-II \#2 & No $(+1)$ & Yes & Yes & No $(+1)$ & Yes & Moderate (2) \\
\hline CFA & CFA \#1 & No $(+1)$ & No $(+1)$ & $\mathrm{No}^{\mathrm{g}}(+2)$ & No $(+1)$ & Yes & High (5) \\
\hline CFA & CFA \#2 & No $(+1)$ & $\mathrm{No}(+1)$ & $\mathrm{No}^{\mathrm{g}}(+2)$ & No $(+1)$ & Yes & High (5) \\
\hline EBR-I & EBR-I & No $(+1)$ & No $(+1)$ & $\mathrm{No}^{\mathrm{g}}(+2)$ & Yes & Yes & Moderate (4) \\
\hline Gun Range & Gun Range & No $(+1)$ & Yes & Yes & No $(0)$ & Yes & Low (1) \\
\hline INTEC & СРP \#4 & No $(+1)$ & Yes & $\mathrm{No}^{\mathrm{g}}(+2)$ & No $(+1)$ & $\mathrm{No}^{\mathrm{h}}(+1)$ & High (5) \\
\hline INTEC & СРP \#5 & Yes & Yes & Yes & Yes & $\mathrm{No}^{\mathrm{h}}(+1)$ & Low (1) \\
\hline Main Gate Facility & Main Gate & No $(+1)$ & Yes & Yes & No $(+1)$ & No $(+1)$ & Moderate (2) \\
\hline $\mathrm{NRF}$ & NRF-2 & No $(+1)$ & No $(+1)$ & $\mathrm{No}^{\mathrm{g}}(+2)$ & No $(+1)$ & No $(+1)$ & High (6) \\
\hline $\mathrm{NRF}$ & NRF-3 & Yes & Yes & Yes & No $(+1)$ & Yes & Low (1) \\
\hline $\mathrm{PBF}$ & PBF \#1 & No $(+1)$ & No $(+1)$ & $\mathrm{No}^{\mathrm{g}}(+2)$ & No $(+1)$ & Yes & High (5) \\
\hline PBF & PBF \#2 & Yes & Yes & Yes & No $(+1)$ & Yes & Low (1) \\
\hline RWMC & RWMC & No $(+1)$ & Yes & Yes & No $(+1)$ & Yes & Moderate (2) \\
\hline $\mathrm{TAN} / \mathrm{CTF}$ & CTF \#1 & No $(+1)$ & No $(+1)$ & $\mathrm{No}^{\mathrm{g}}(+2)$ & No $(+1)$ & Yes & High (5) \\
\hline TAN/CTF & $\mathrm{CTF} \# 2$ & No $(+1)$ & No $(+1)$ & $\mathrm{No}^{\mathrm{g}}(+2)$ & Yes & Yes & Moderate (4) \\
\hline TAN/TSF & TSF \#1 & No $(+1)$ & Yes & Yes & No $(+1)$ & Yes & Moderate (2) \\
\hline TAN/TSF & TSF \#2 & Yes & Yes & Yes & No $(+1)$ & Yes & Low (1) \\
\hline TRA & TRA \#1 & No $(+1)$ & $\mathrm{No}^{\mathrm{i}}(+1)$ & $\mathrm{No}^{\mathrm{i}}(+2)$ & No $(+1)$ & Yes & High (5) \\
\hline
\end{tabular}


Table 3-5. (continued).

\begin{tabular}{|c|c|c|c|c|c|c|c|}
\hline Facility & $\begin{array}{l}\text { Well }^{\mathrm{a}} \\
\text { Name }\end{array}$ & $\begin{array}{l}\text { Meets Idaho } \\
\text { Well } \\
\text { Construction } \\
\text { Standards? }^{\mathrm{b}} \\
(\mathrm{X}+1)\end{array}$ & $\begin{array}{c}\text { Wellhead }{ }^{\mathrm{c}, \mathrm{d}} \text { and } \\
\text { Surface Seal in } \\
\text { Good Condition? } \\
(\mathrm{X}+1)\end{array}$ & $\begin{array}{l}\text { Casing }^{\mathrm{c}, \mathrm{d}} \text { and } \\
\text { Annular Seal } \\
\text { Extend to Low } \\
\text { Permeability } \\
\text { Unit? } \\
\text { (X+2) }\end{array}$ & $\begin{array}{c}\text { Well Intake } \geq 100 \\
\text { Feet Below Static } \\
\text { Water Level? } \\
(\mathrm{X}+1)\end{array}$ & $\begin{array}{l}\text { Wellhead }^{\mathrm{e}} \text { is } \\
\text { Protected from } \\
\text { Flooding? } \\
(\mathrm{X}+1)\end{array}$ & $\begin{array}{c}\text { System }^{\mathrm{f}} \\
\text { Construction Score } \\
\text { (Total) }\end{array}$ \\
\hline TRA & TRA \#3 & Yes & Yes $^{\mathrm{j}}$ & $\mathrm{Yes}^{\mathrm{j}}$ & Yes & Yes & Low $(0)$ \\
\hline TRA & TRA \#4 & No $(+1)$ & $\mathrm{No}^{\mathrm{i}}(+1)$ & $\mathrm{No}^{\mathrm{i}}(+2)$ & No $(+1)$ & Yes & High (5) \\
\hline
\end{tabular}

a. Well names are those listed in the INEEL Drinking Water Program Plan followed by the official INEEL well name, as listed in the Comprehensive Well Survey for the Idaho National Engineering Laboratory (Sehlke et al. 1993).

b. INEEL wells were evaluated against Idaho well construction standards and industry standards (Sehlke et al. 1993).

c. All wellheads at the INEEL were inspected and upgraded, as necessary, by the INEEL Comprehensive Well Survey Program in the mid-1990s.

d. Since surface and annular seals generally cannot be observed once a well is completed, this evaluation must be based solely on well construction information and knowledge of the general performance of the seal materials and methods used.

e. The wellhead is located outside of the 100 -Year floodplain and is protected from surface runoff?

f. Low System Construction Score (0-1); Moderate System Construction Score (2-4); High System Construction Score (5-6).

g. The surface casing extends to bedrock, but there is either insufficient information to determine if a surface seal exists, or the well was improperly sealed (e.g., back filled with drill cuttings/soil). However, there are no conditions in the area that would cause ponding of surface water and no know perched water zones are present in this area, so it is unlikely that this would be a significant contaminant pathway.

h. Well is within the Big Lost River 100-year floodplain.

i. The surface and annual seals appear to be inadequate to prevent surface or groundwater contamination from entering the well. In addition, the well may be within the TRA 150 -foot perched water zone, which is known to be contaminated with contaminants of concern. Therefore, remediation or abandonment may be necessary.

j. The surface and annual seals appear to be adequate to prevent surface or groundwater contamination from entering the well, however,, well may be within the TRA 150-foot perched water zone. Since this zone is contaminated with contaminants of concern, additional monitoring may be warranted. 


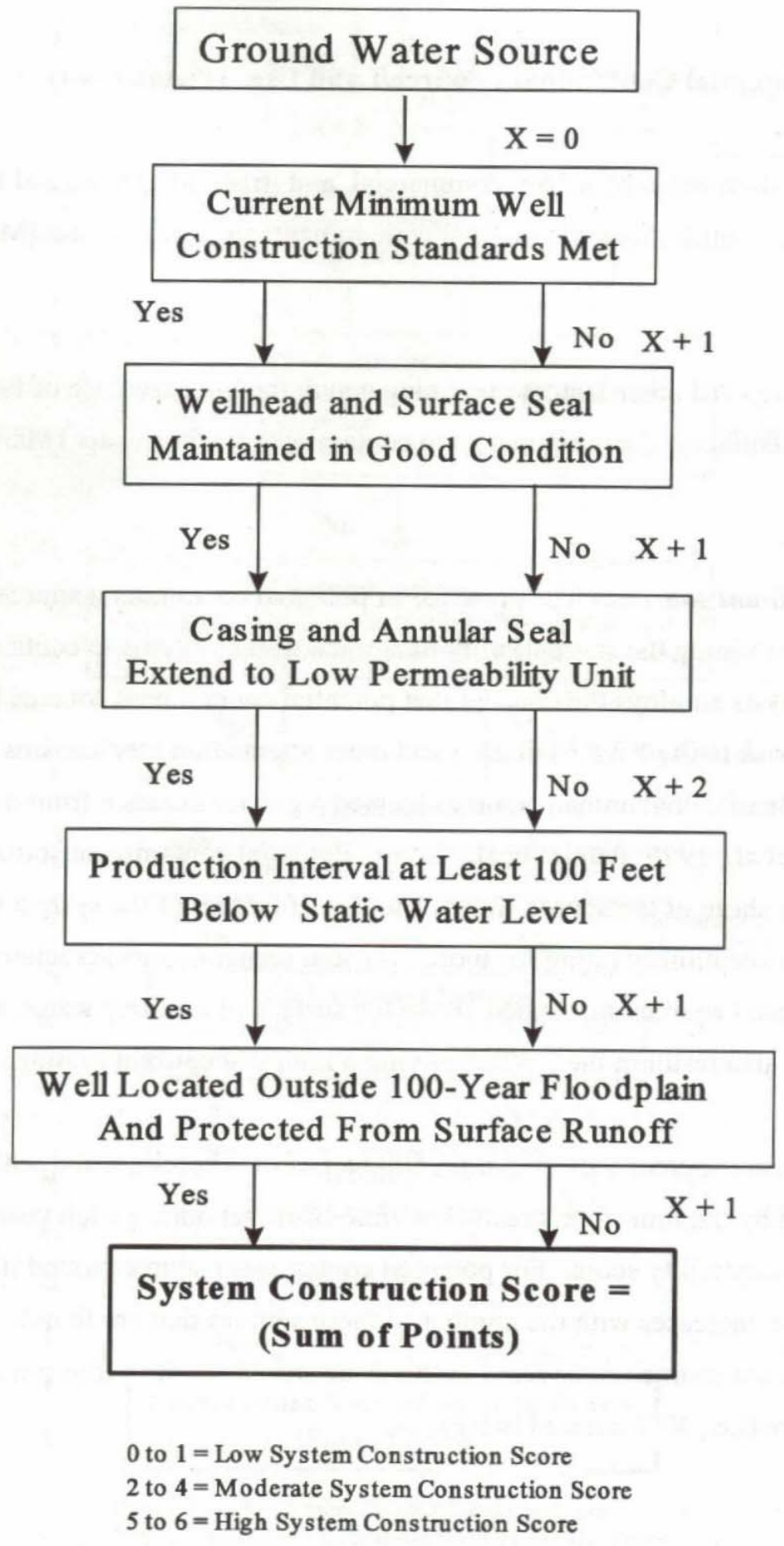

Figure 3-3. System construction analysis (from DEQ 1999). 
Table 3-6. Five-year summary of drinking water parameters of interest at the INEEL.

\begin{tabular}{|c|c|c|c|c|}
\hline Location & Parameter & Average Results & MCL & Year \\
\hline CFA Distribution System & Tritium $^{\mathrm{a}}$ & $9,719 \pm 643-12,786 \pm 1,003 \mathrm{pCi} / \mathrm{L}$ & $20,000 \mathrm{pCi} / \mathrm{L}$ & 1997-2001 \\
\hline CFA Well \#1 & Tritium & $10,597 \pm 696-13,391 \pm 1,047 \mathrm{pCi} / \mathrm{L}$ & $\mathrm{N} / \mathrm{A}^{\mathrm{b}}$ & 1997-2001 \\
\hline CFA Well \#2 & Tritium & $9,844 \pm 652-11,774 \pm 929 \mathrm{pCi} / \mathrm{L}$ & $\mathrm{N} / \mathrm{A}^{\mathrm{b}}$ & 1997-2001 \\
\hline INTEC Distribution & Total coliform & Present $^{\mathrm{c}}$ & Absence & 1999 \\
\hline $\mathrm{NRF}$ & Total coliform & Present $^{\mathrm{c}}$ & Absence & 1999 \\
\hline $\begin{array}{l}\text { RWMC Distribution } \\
\text { System }\end{array}$ & Carbon tetrachloride ${ }^{\mathrm{b}}$ & $2.33-2.80 \mu \mathrm{g} / \mathrm{L}$ & $5.0 \mu \mathrm{g} / \mathrm{L}$ & 1997-2001 \\
\hline RWMC Well & Carbon tetrachloride & $3.68-4.75 \mu \mathrm{g} / \mathrm{L}$ & $\mathrm{N} / \mathrm{A}$ & 1997-2001 \\
\hline $\begin{array}{l}\text { RWMC Distribution } \\
\text { System }\end{array}$ & Trichloroethylene $^{\mathrm{b}}$ & $1.23-1.45 \mu \mathrm{g} / \mathrm{L}$ & $5.0 \mu \mathrm{g} / \mathrm{L}$ & 1997-2001 \\
\hline RWMC Well & Trichloroethylene & $1.63-2.08 \mu \mathrm{g} / \mathrm{L}$ & $\mathrm{N} / \mathrm{A}$ & 1997-2001 \\
\hline RWMC Distribution & Total coliform & Present $^{\mathrm{c}}$ & Absence & 2001 \\
\hline $\begin{array}{l}\text { TAN/TSF Distribution } \\
\text { System }\end{array}$ & Trichloroethylene & $0.84-1.42 \mu \mathrm{g} / \mathrm{L}$ & $5.0 \mu \mathrm{g} / \mathrm{L}$ & 1997-2001 \\
\hline TAN/TSF Well \#1 & Trichloroethylene & $3.20-6.10 \mu \mathrm{g} / \mathrm{L}$ & $\mathrm{N} / \mathrm{A}$ & 1997-2001 \\
\hline TAN/TSF Well \#2 & Trichloroethylene & $1.00-3.00 \mu \mathrm{g} / \mathrm{L}$ & $\mathrm{N} / \mathrm{A}$ & 1997-2001 \\
\hline TRA Distribution & Total coliform & Present $^{\mathrm{c}}$ & Absence & 1999 \\
\hline
\end{tabular}




\section{CONCLUSION}

A source water assessment is intended to assess a public water system's potential to become contaminated by their surface water and/or groundwater supplies. The State of Idaho's source water assessment process is qualitative in nature in that potential sources of contamination are identified and evaluated based on best available knowledge and conservative rules of thumb rather than extensive sampling and analysis programs, computer modeling, and formal numerical risk assessments. This process establishes a good screening process for evaluating potential contaminant threats to the INEEL's public water systems. However, since this is just a screening tool, it must be kept in mind that the potential sources of contaminants are just that - potential sources. Unless a source is specifically stated as a known source (e.g., in the case of groundwater contaminant plumes), it should not be assumed that they can or that they necessarily will impact the given public water system.

The INEEL Source Water Assessment includes an evaluation of 12 INEEL public water systems. All INEEL public water systems are supplied directly via groundwater withdrawals from the eastern Snake River Plain Aquifer. However, the eastern Snake River Plain Aquifer in the vicinity of these systems receives surface water/groundwater recharge from seven watersheds and three aquifers. Within the seven watersheds, three contain streams that flow onto or near the INEEL (the Big Lost River, Little Lost River, and Birch Creek). Each of these are known to be directly "hydrologically connected" to the eastern Snake River Plain Aquifer (e.g., they discharge directly to the eastern Snake River Plain). Therefore, they each warranted further investigation to determine if they "directly influence" the eastern Snake River Plain Aquifer in the vicinity of the INEEL's public water systems, hence they may be potential sources of microbial contamination to those systems. It was determined that none of these streams meet the state's definition of directly influencing groundwater supplies; therefore, no further evaluations are required for these surface water sources. Initial evaluations of the associated aquifer systems confirmed the eastern Snake River Plain Aquifer is sole source of water for the INEEL's public water systems and that none of the other aquifers discharge close enough to the INEEL's systems to warrant additional evaluation for source water assessment purposes.

Development of the INEEL's contaminant source inventory likely varies from those conducted by most public water systems. The INEEL is a highly regulated facility that has undergone numerous formal evaluations (e.g., under RCRA, CERCLA and DOE orders) to characterize and estimate the level of risk posed by known and potential contaminant sources. Therefore, many potential sources were initially evaluated to determine their potential to contaminate groundwater sources. This source water assessment was limited to those potential sources that these previous studies considered to have a reasonable possibility of causing groundwater contamination. It should also be noted that although ordnances are not considered to be a threat to the INEEL's groundwater resources, they are of special interest to the INEEL from a health and safety standpoint. Therefore, the ordnance footprint was retained on the figures in this document.

Using the State of Idaho's evaluation process and criteria (DEQ 1999), the INEEL evaluated each system for hydrologic, contaminant/land use, and system construction sensitivities. The scores developed for each of these systems were estimated, weighted as appropriate (see Figure 4-1), and summed in order to estimate each system's relative susceptibility to becoming contaminated. These results are provided in Table 4-1. Despite the thickness of the vadose zone at the INEEL, the systems generally scored as moderately to highly susceptible based on their hydrologic sensitivities. In general, this is due to the lack of thick "impermeable" interbeds and/or aquitards in the vicinity of the systems. There was a fairly even spread of scores based on contaminant/land use sensitivity evaluations. In all cases, those systems ranked as highly susceptible were due to potential sources of contamination being located in Zone 1A or contamination being detected during routine Safe Drinking Water Act sampling rather than cumulative risk. 
PWS Name

PWS \#

\section{PWS Well/Intake Identification}

Person Conducting Assessment

\section{Ground Water Source}

\begin{tabular}{|c|c|}
\hline Community and Noncommunity, nontransient systems & Transient Systems \\
\hline Hydrologic Sensitivity Score $=$ & \multirow{4}{*}{ 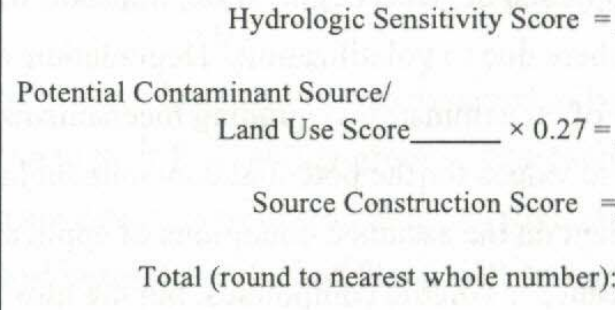 } \\
\hline $\begin{array}{l}\text { Potential Contaminant Source/ } \\
\qquad \text { Land Use Score___ } \times 0.20=\end{array}$ & \\
\hline Source Construction Score $=$ & \\
\hline Total (round to nearest whole number): & \\
\hline (circle the rank) Rank: & loderate $=6-12$ \\
\hline
\end{tabular}

\section{Surface Water Source}

\begin{tabular}{|c|}
\hline Any Surface Water Source \\
\hline $\begin{array}{r}\text { Potential Contaminant Source/Land Use Score }= \\
\text { Source Construction Score }= \\
\text { Total: } \\
\end{array}$ \\
\hline
\end{tabular}

(circle the rank) Rank: $\quad$ Low $=0-7 ; \quad$ Moderate $=8-15 ; \quad$ High $=16-21$ Comments:

Figure 4-1. Susceptibility Rating Sheet. 
Table 4-1. Overall susceptibility ratings of public water systems at the INEEL.

\begin{tabular}{|c|c|c|c|c|c|c|c|}
\hline Facility & $\begin{array}{c}\text { Well } \\
\text { Name }\end{array}$ & $\begin{array}{l}\text { Hydrologic } \\
\text { Sensitivity }\end{array}$ & $\begin{array}{l}\text { Contaminant/ } \\
\text { Land Use Score }\end{array}$ & $\begin{array}{c}\text { Adjusted } \\
\text { Groundwater } \\
\text { Score } \\
\end{array}$ & $\begin{array}{c}\text { System } \\
\text { Construction } \\
\text { Score } \\
\end{array}$ & $\begin{array}{c}\text { Overall Well } \\
\text { Susceptibility }^{\mathrm{a}} \\
\text { Rating }\end{array}$ & $\begin{array}{c}\text { Overall PWS } \\
\text { Susceptibility } \\
\text { Rating }\end{array}$ \\
\hline ANL-W & EBR-II \#1 & $\begin{array}{l}\text { Moderate } \\
\text { (3) }\end{array}$ & Med. (14) & 3 & High (5) & Moderate (11) & Moderate \\
\hline ANL-W & EBR-II \#2 & $\begin{array}{l}\text { Moderate } \\
\text { (3) }\end{array}$ & $\operatorname{High}(21)^{b}$ & 4 & Moderate (2) & Moderate (9) & \\
\hline CFA & CFA \#1 & $\begin{array}{l}\text { Moderate } \\
\text { (3) }\end{array}$ & $\operatorname{High}(21)^{b}$ & 4 & High (5) & Moderate (12) & Moderate \\
\hline CFA & CFA \#2 & High (5) & $\operatorname{High}(21)^{\mathrm{b}}$ & 4 & High (5) & Moderate (14) & \\
\hline EBR-I & EBR-I & Low (1) & Low $(0)$ & 0 & Moderate (4) & Low (5) & Low \\
\hline Gun Range & Gun Range & High (5) & Low (0) & 0 & Low (1) & Low (6) & Low \\
\hline INTEC & СРP \#4 & High (5) & $\operatorname{High}(21)^{b}$ & 4 & High (5) & Moderate (14) & Moderate \\
\hline INTEC & CPP \#5 & High (5) & $\operatorname{High}(21)^{b}$ & 4 & Low (1) & Moderate (10) & \\
\hline $\begin{array}{l}\text { Main Gate } \\
\text { Facility }\end{array}$ & Main Gate & High (5) & Low (0) & 0 & Moderate (2) & Low (7) & Low \\
\hline $\mathrm{NRF}$ & NRF-2 & High (5) & $\operatorname{High}(21)^{\mathrm{b}}$ & 4 & High (6) & Moderate (15) & Moderate \\
\hline NRF & NRF-3 & High (5) & $\operatorname{High}(21)^{b}$ & 4 & Low (1) & Moderate (10) & \\
\hline PBF & PBF \#1 & $\begin{array}{l}\text { Moderate } \\
\text { (3) }\end{array}$ & Med. (13) & 3 & $\operatorname{High}(5)$ & Moderate (11) & Moderate \\
\hline PBF & PBF \#2 & $\begin{array}{l}\text { Moderate } \\
\text { (3) }\end{array}$ & Med. (13) & 3 & Low (1) & Low (7) & \\
\hline RWMC & RWMC & $\begin{array}{l}\text { Moderate } \\
\text { (3) }\end{array}$ & $\operatorname{High}(21)^{b}$ & 4 & Moderate (2) & Moderate (9) & Moderate \\
\hline TAN/CTF & CTF \#1 & $\begin{array}{l}\text { Moderate } \\
\text { (2) }\end{array}$ & Low (2) & 0 & High (5) & Low (7) & Moderate \\
\hline TAN/CTF & CTF \#2 & $\begin{array}{l}\text { Moderate } \\
\text { (4) }\end{array}$ & Low (2) & 0 & Moderate (4) & Moderate (8) & \\
\hline TAN/TSF & TSF \#1 & $\begin{array}{l}\text { Moderate } \\
\text { (4) }\end{array}$ & $\operatorname{High}(21)^{\mathrm{b}}$ & 4 & Moderate (2) & Moderate (10) & Moderate \\
\hline TAN/TSF & TSF \#2 & $\begin{array}{l}\text { Moderate } \\
\text { (4) }\end{array}$ & $\operatorname{High}(21)^{b}$ & 4 & Low (1) & Moderate (9) & \\
\hline TRA & TRA \#1 & High (5) & $\operatorname{High}(21)^{b}$ & 4 & High (5) & Moderate (14) & Moderate \\
\hline TRA & TRA \#3 & High (5) & $\operatorname{High}(21)^{b}$ & 4 & Low (0) & Moderate (9) & \\
\hline TRA & TRA \#4 & High (5) & $\operatorname{High}(21)^{\mathrm{b}}$ & 4 & High (5) & Moderate (14) & \\
\hline
\end{tabular}

a. Low $=0-7$; Moderate $=8-15 ;$ High $=16-21$.

b. Detection of contamination from the groundwater source automatically defaults the score to "High". All systems defaulted to high in contaminant/land use assessment were assigned a score of 21.

There is a fairly even spread of scores based on system construction sensitivities. In the vast majority of cases, the reason wells scored "highly sensitive" to potential contaminants based on construction is because of inadequate surface and/or annular seals or, in many cases, a lack of documentation to prove that they were adequately sealed. Many of these wells were constructed prior to the development of the state's well construction standards. All of these wells were constructed with a surface casing to the first competent geological formation (typically the first basalt layer) and a full well casing to the completion zone. However, the general practice at that time was to backfill the annular spaces with soil or clay with intermittent grout or cement "cutoffs" at key geologic points. Because of the ages of these wells, the specific construction of the wells, especially aspects of the surface and annular seals, were not always well documented; therefore, many of the cumulative scores for these wells were defaulted to highly sensitive. However, because most were well constructed and/or they are not located 
near large potential sources of water or contamination, it is not believed that most are susceptible to becoming contaminated.

Out of the 21 wells assessed, 5 scored a low susceptibility range, 16 scored a moderate susceptibility range, and none scored in the high susceptibility range. These scores were combined for the INEEL facilities that use more than one well. In each case, the highest total well score was used as the "Overall PWS Susceptibility Rating." These scores are reasonable considering the history and the industrial nature of the work being conducted at some of the INEEL facilities. It also demonstrates that the INEEL must continue to be vigilant in monitoring its public water systems, and in evaluating, managing, and/or mitigating its activities that could potentially impact its drinking water supplies.

Using the State of Idaho's rating system, of the 21 wells evaluated, 5 scored a low overall susceptibility rating, and the remainder scored a moderate overall susceptibility rating. No INEEL wells were rated as high susceptibility to known or potential contaminants.

The individual total well susceptibility scores were combined for each public water system. This was accomplished by defaulting to the rating of the highest overall well score for the given facility. Of the INEEL's 12 public water systems, 3 systems rated as low susceptibility, and the remainder rated as moderate susceptibility. No INEEL public water system rated as high susceptibility.

The purpose of conducting the INEEL source water assessment is to have a qualitative understanding of the relative risk of the INEEL's public water systems becoming contaminated and to take proactive or other measures to mitigate those risks. In addition, there has been much historical and ongoing work at the INEEL to quantify these risks, and many historical and ongoing activities are treating or removing known and potential sources of contamination at the INEEL. The findings of this source water assessment and the results of other historical/ongoing findings and results will be evaluated, and where appropriate, recommendations will be made for systematically addressing known/potential sources of contamination that could negatively impact the INEEL public water systems. These recommendations will be documented in an INEEL Source Water Management Plan in 2003. 


\section{GLOSSARY}

(After DEQ 1999)

Analytical model —A model that provides approximate or exact solutions to simplified forms of the differential equations for water movement and solute transport. Analytical models can generally be solved with calculators or computers.

Aquifer-A geological formation of permeable saturated material, such as rock, sand, gravel, etc., capable of yielding economically significant quantities of water to wells and springs.

Area of influence-Area surrounding a pumping or recharging well within which the water table or potentiometric surface has been changed due to the well's pumping or recharge.

Beneficial uses-Any of the various uses that may be made of the water of an area, including, but not limited to, domestic water supplies, industrial water supplies, agricultural water supplies, navigation, recreation in and on the water, wildlife habitat, and aesthetics.

Best management practice (BMP) - A practice or combination of practices determined to be the most effective and practical means of preventing or reducing contaminations to groundwater and/or surface water from nonpoint and point sources to achieve water quality goals and protect the beneficial uses of the water.

Buffer zone-The area between a lake and a boundary some distance from the lake; or, the area within two boundaries, one on either side of a creek or river that extend along some portion of the creek or river.

Community water system - A public water system with at least 15 service connections used by year-round residents of the system area or which regularly serves at least 25 year-round residents.

Confined aquifer - An aquifer bounded above and below by confining units of distinctly lower permeability than the aquifer media. An aquifer in which groundwater is under pressure significantly greater than atmospheric, and its upper limit is the bottom of a bed of distinctly lower hydraulic conductivity than that of the aquifer itself. The confined groundwater within the aquifer will generally exhibit artesian characteristics.

Confining unit-A hydrogeologic unit of relatively impermeable material, bounding one or more aquifers. This is a general term that has replaced aquitard, aquifuge, and aquiclude and is synonymous with confuting bed. A body of material of low hydraulic conductivity that is stratigraphically adjacent to one or more aquifers. It may lie above or below the aquifer.

Contaminant - Any chemical, ion, radionuclide, synthetic organic compound, microorganism, waste or other substance that does not occur naturally in groundwater or that naturally occurs at a lower concentration.

Contamination - The direct or indirect introduction into groundwater or surface water or source water of any contaminant caused in whole or in part by human activities.

Cryptosporidium - Generic name - Cryptosporidiumpavum-A parasitic protozoan that can be transmitted to humans via contaminated drinking water. The organism can cause an intestinal illness call cryptosporidiosis, which may be life threatening to people with weak immune systems. The most common symptom is watery diarrhea, but there may also be cramps, fever, nausea, vomiting, and loss of appetite. There is no specific medical treatment for cryptosporidiosis. 
Delineation (delineate) — The process of defining or mapping a boundary that shows the areas that contribute water to a particular water source used as a public water supply. For surface waters, the land area usually consists of the watershed for a reservoir or stream. For groundwater sources, the boundary typically encompasses the real extent of the aquifer that contributes water to the PWS.

Designated beneficial use or designated use-Those beneficial uses assigned to identified waters in Idaho Department of Health and Welfare Rules, Title 1, Chapter 2, Water Quality Standards and Wastewater Treatment Requirements, Section 110. through 160. and 299., whether or not the uses are being attained.

Discharge area-An area in which groundwater is discharged to the land surface, surface water, or atmosphere. An area in which there are upward components of hydraulic head in the aquifer.

Groundwater is flowing toward the surface in a discharge area and may escape as a spring, a seep, stream base flow, or by evaporation and transpiration.

DWIMS —IDEQ Drinking Water Information Management System.

Effective porosity $\left(n_{e}\right)$ - The amount of interconnected pore space through which fluids can pass, expressed as a percent of bulk volume. Part of the total porosity will be occupied by static fluid being held to the mineral surface by surface tension, so effective porosity will be less than total porosity.

Entire watershed upstream of the intake-The topographic boundary, up to the state border, that is the perimeter of the catchment basin that provides water to the intake structure.

Environment - Collectively, the surrounding conditions, influences, and living and inert matter that affect a particular organism or biological community.

Existing beneficial use or existing use-Those beneficial uses actually attained in waters on or after November 28, 1975, whether or not they are designated for those waters in Idaho Department of Health and Welfare Rules Title 1, Chapter 2, "Water Quality Standards and Wastewater Treatment Requirements."

Flow model - A digital computer model that calculates a hydraulic head field for the modeling domain using numerical methods to arrive at an approximate solution to the differential equation of groundwater flow.

Geographic information system (GIS) -An organized collection of computer hardware, software, geographic data, and personnel designed to efficiently capture, store, update, manipulate, analyze, and display all forms of geographically referenced information.

Giardia - Generic name for Giardia lamblia, a parsitic protozoan that can be transmitted to humans via contaminated drinking water. The organism can cause an intestinal illness called giardiasis of which the main symptom is mild or severe diarrhea. Giardia can be treated with anti-parasitic drugs.

$G P D$ - Gallons per day, a commonly used measure of the withdrawal rate of a well.

Global Positioning System (GPS) — A system that allows users, with the proper equipment, to receive and analyze data broadcast from a network of satellites orbiting the earth, which determines their location according to latitude and longitude.

Groundwater-Any water of the state that occurs beneath the surface of the earth in a saturated geologic formation of rock or soil. 
Ground Water Disinfection Rule-Under Section 107 of the Safe Drinking Water Act Amendments of 1996, the statute reads, “...the Administrator shall also promulgate national primary drinking water regulations requiring disinfection as a treatment technique for all public water systems, including surface water systems, as necessary, ground water systems."

Groundwater flow-The movement of groundwater through openings in sediment and rock that occurs in the zone of saturation.

Groundwater model - A simplified conceptual or mathematical image of a groundwater system, describing the feature essential to the purpose for which the model was developed and including various assumptions pertinent to the system. Mathematical groundwater models can include numerical and analytical models.

Groundwater under the direct influence of surface water (GWUDI) - Any water beneath the surface of the ground with (1) significant occurrence of insects or other macroorganisms, algae, or large diameter pathogens such as Giardia lambha, or (2) significant and relatively rapid shifts in water characteristics such as turbidity, temperature, conductivity, or $\mathrm{pH}$ which closely correlate to climatological or surface water conditions.

Hydraulic conductivity - The capacity of a rock or porous media to transmit water. The rate of flow of water in gallons per day through a cross section of one square foot under a unit hydraulic gradient, at the prevailing temperature $\left(\mathrm{gpd} / \mathrm{ft}^{2}\right)$. The density and viscosity of the water must be considered in determining hydraulic conductivity.

Hydraulic gradient (I) - Slope of water table or potentiometric surface. More specifically, change in static head per unit of distance in a given direction, generally the direction of the maximum rate of decrease in head. The rate of change in total head per unit of distance of flow in a given direction. The change in total head with a change in distance in a given direction. The direction is that which yields a maximum rate of decrease in head. The difference in hydraulic heads $\left(\mathrm{h}_{1}-\mathrm{h}_{2}\right)$, divided by the distance $(\mathrm{L})$ along the flowpath. $\mathrm{I}=\left(\mathrm{h}_{1}-\mathrm{h}_{2}\right) / \mathrm{L}$.

Hydrogeologic - Those factors that deal with subsurface waters and related geologic aspects of surface waters.

Hydrogeologic parameters - Numerical parameters that describe the hydrogeologic characteristics of an aquifer such as porosity, permeability, and transmissivity.

Hydrologic basin - The area of land drained by a river system, a reach of a river and its tributaries in that reach, a closed basin, or a group of streams forming a drainage area. There are six basins described in the Nutrient Management Act (NMA) for Idaho-Panhandle, Clearwater, Salmon, Southwest, Upper Snake, and the Bear Basin.

Infiltration rate-Rate at which soil or rock under specified conditions absorbs falling rain, melting snow, or other forms of surface water; expressed in depth of water per unit time.

Land application-A process or activity involving application of wastewater, surface water, or semi-liquid material to the land surface for the purpose of disposal, pollutant removal, or groundwater recharge.

Loading - The quantity of a substance entering a receiving stream, usually expressed in pounds (kilograms) per day or tons per month. Loading is calculated from flow (discharge) and concentration. 
Maximum Contaminant Level (MCL) -Maximum permissible level of a contaminant in water that is delivered to the users of a public water supply system. MCL is defined more explicitly in Safe Drinking Water Act regulations (40 CFR Section 141.2).

$M G D$-Million gallons per day, a commonly used measure of the withdrawal rate of large wells.

Monitoring - The process of watching, observing, or checking (in this case water). The entire process of a water quality study including: planning, sampling, sample analyses, data analyses, and report writing and distribution.

Monitoring waiver - A temporary reduction in sampling requirements for a particular contaminant. Even after a waiver is received, some monitoring at a reduced frequency will usually be required. Waivers must be applied for and granted in writing.

National Pollution Discharge Elimination System (NPDES) - A national program from the Clean Water Act for issuing, modifying, revoking and reissuing, terminating, monitoring and enforcing permits to discharge pollutants to water of the United States, including pretreatment requirements.

Noncommunity water system-A public water system that is not a community water system. There are two types of noncommunity water systems: transient and non-transient.

Nonpoint source-A potential source of contamination having diffuse or multiple discharges of contaminants that are spread over a large area.

Nontransient noncommunity water system-A water system that does not meet the definition of a community supply and that serves at least 25 of the same persons, 4-hours or more per day, for 4 or more days per week, for 26 or more weeks. Examples of nontransient noncommunity systems include schools, offices, and factories.

Numerical model - A model that provides approximate solution to the specific forms of the differential equations for water movement and solute transport. Numerical models require comuters for their solution but have greater flexibility in the range of real-world problems that can be solved, compared to analytical models.

Perched groundwater-Unconfined groundwater separated from an underlying main body of groundwater by an unsaturated zone.

Percolation-Downward movement of water through the unsaturated zone; the act of water seeping or filtering through the soil without a definite channel.

Permeability - Ability of a porous medium to transmit fluids under a hydraulic gradient. The property or capacity of a porous rock, sediment, or soil for transmitting a fluid; a measure of the relative ease of fluid flow under unequal pressure.

Point source-Any discernible, confined, and discrete conveyance, including, but not limited to any pipe, ditch, channel, tunnel, conduit, well, discrete fissure, container, rolling stock, concentrated animal feeding operation, or vessel or other floating craft, from which pollutants are, or may be, discharged. This term does not include return flows from irrigated agriculture, discharges from dams and hydroelectric generating facilities or any source or activity considered a nonpoint source by definition. 
Potable water-A water free from impurities in such amounts that it is safe for human consumption without treatment.

Potential contaminant source inventory - The process of identifying and inventorying contaminant sources within delineated source water areas. Inventory steps include: using existing contaminant sources locations and description data, identifying likely sources for further information, and verifying accuracy and reliability of the data sets.

Public drinking water system - A community, noncommunity, or nontransient noncommunity water system that provides piped water to the public for human consumption. The system must have at least 15 service connections or regularly serve at least 25 individuals daily for at least 60 days.

Radius of influence - The radial distance from the center of a well bore to the point where there is no lowering of the water table or potentiometric surface (the edge of its cone of depression).

Recharge - The addition of water to the zone of saturation; also, the amount of water added. Can be expressed as a rate (i.e., in/yr) or a volume.

Recharge area-An area in which water infiltrates into the soil or geological formation from sources such as precipitation, irrigation practices, and seepage from creeks, streams or lakes, and percolates to one or more aquifers.

Recharge boundary - An aquifer system boundary that adds water to the aquifer. Streams and lakes are typical recharge boundaries.

Riparian-Associated with aquatic (streams, rivers, lakes) habitats. Living or located on the bank of a water body.

Runoff - The portion of rainfall, melted snow, or irrigation water that flows across the surface or through underground zones and eventually runs into surface water bodies.

Safe Drinking Water Act (SDWA) - The federal law that authorizes the U.S. Environmental Protection Agency and states to oversee public water systems and set standards for drinking water.

Significant potential source of contamination-A facility or activity that stores, uses, or produces chemicals or elements and that has the potential to release contaminants identified in a state program (contaminants with MCLs plus any others a state considers a health threat) within a source water area in an amount that could contribute significantly to the concentration of the contaminants in the source waters of the public water system.

Source water or water source-Any aquifer, surface water body, or watercourse from which water is taken either periodically or continuously by a public water system for drinking or food processing purposes.

Source water assessment - Provides information on the potential contaminant threats to public drinking water sources. Each source water assessment consists of a delineation of the water source area, a contaminant inventory, and a susceptibility analysis.

Source water assessment area-The part of the watershed or groundwater area that contributes to the water supply. 
Spring-Discrete discharge area where groundwater flows naturally from rock or soil onto the land surface or into a surface-water body.

Storm water runoff-Surface water that washes off land after a rainstorm. In developed watersheds it flows off roofs and pavement into storm drains, which may feed directly into the stream; often carries pollutants.

Sub-watershed - Smaller geographic management areas within a watershed delineated for purposes of addressing site-specific situations.

Surface water(s) - All water that is open to the atmosphere and subject to surface runoff. Lakes, ponds, streams, rivers, and other water bodies that lie on the surface of the land. Surface waters may be partially or fully supplied by groundwater.

Surface Water Treatment Rule-A Safe Drinking Water Act rule that specifies maximum contaminant level goals for Giardia lamblia, viruses and Legionelias, and promulgated filtration and disinfection requirements for public water systems using surface water sources or by groundwater sources under the direct influence of surface water. The regulations also specified water quality, treatment, and watershed protection criteria under which filtration may be avoided.

Susceptibility analysis - An evaluation of conditions in the source water area to determine the potential for contaminants to impact water quality at the wellhead or surface water intake.

Time of travel (TOT) - The time required for a contaminant to move in the saturated zone from a specific point to a well.

Total maximum daily load (TMDL) - The sum of the individual wasteload allocations for point sources, load allocations for nonpoint sources, and natural background. Such load shall be established at a level necessary to implement the applicable water quality standards with seasonal variations and a margin of safety that takes into account any lack of knowledge concerning the relationship between effluent limitations and water quality.

Total suspended solids (TSS)—The material retained on a 2.0 micron filter after filtration.

Transmissivity (T) - Rate at which water of the prevailing kinematic viscosity is transmitted through a unit width of the aquifer under a unit hydraulic gradient. Transmissivity values are given in gallons per day through a vertical section of an aquifer 1 foot wide and extending the full saturated height of an aquifer under a hydraulic gradient of one. It is a function of properties of the liquid, the porous media, and the thickness of the porous media.

Tributary -A stream feeding into a larger stream or lake.

Turbidity - A measure of the extent to which light passing through water is scattered due to suspended materials. Excessive turbidity may interfere with light penetration and minimize photosynthesis, thereby causing a decrease in primary productivity. It may alter water temperature and interfere directly with essential physiological functions of fish and other aquatic organisms, making it difficult for fish to locate for a food source.

Water pollution-Any alteration of the physical, thermal, chemical, biological, or radioactive properties of any waters of the state, or the discharge of any pollutant into the waters of the state, which will or is likely to create a nuisance or to render such waters harmful, detrimental, or injurious to public health, 
safety, or welfare, or to fish and wildlife, or to domestic, commercial, industrial, recreational, aesthetic, or other beneficial uses.

Water quality management plan -A state or area-wide waste treatment management plan developed and updated in accordance with the provisions of the Clean Water Act.

Watershed -A drainage area or basin in which all land and water areas drain or flow toward a central collector such as a stream, river, or lake at a lower elevation. The whole geographic region contributing to a water body.

Watershed approach - A coordinating framework for environmental management that focuses public and private sector efforts to address the highest priority problems within hydraulically-defined geographic areas, taking into consideration both ground and surface water flow.

Wellfield-An area containing two or more wells with overlapping zones of contribution that supply a public water supply system.

Wellhead-The physical structure, facility, or device at the land surface from or through which groundwater flows or is pumped from subsurface water-beating formations.

Wellhead protection area (WHPA) - The surface and subsurface area surrounding a water well or wellfield, supplying a public water system, through which contaminants are reasonably likely to move toward and reach such water well or well field.

Wellhead Protection Program-Under Section 1428 of the Safe Drinking Water Act, states are required to adopt a program designated to protect groundwater-based sources of drinking water. The Idaho Wellhead Protection Program received EPA approval in 1996.

Well yield-The rate of discharge of water from a well, measured in gallons per minute or cubic meters per day.

Wetlands - Lands transitional between terrestrial and aquatic systems where the water table is usually at or near the surface or the land is covered by shallow water. Wetlands must have the following three attributes: (1) at least periodically, the land supports predominately hydrophytes; (2) the substrate is predominantly undrained hydric soil; and (3) the substrate is on soil and is saturated with water or covered by shallow water at some time during the growing season of each year.

Zone of contribution-The area surrounding a pumping well that encompasses all areas or features that supply groundwater recharge to the well.

Zone of influence-The area surrounding a pumping well within which the water table or potentiometric surfaces have been changed due to groundwater withdrawal.

Zone of transport-The area surrounding a pumping well through which a contaminant may travel and reach the well. 


\section{REFERENCES}

40 CFR Part 136, "Guidelines Establishing Test Procedures for the Analysis of Pollutants," Code of Federal Regulations, Office of the Federal Register.

40 CFR Parts 141-143, "Protection of Environment," Code of Federal Regulations, Office of the Federal Register.

Ackerman, D. J. (USGS), 1991, Transmissivity of the Snake River Plain Aquifer at the Idaho National Engineering Laboratory, Idaho, U.S. Geological Survey Water-Resources Investigations Report 91-4058, DOE/ID-22097.

Barraclough, J. T. and R. G. Jensen (USGS), 1976, Hydrologic Data for the Idaho National Engineering Laboratory Site, Idaho, 1971 to 1973, U.S. Geological Survey Open-File Report 75-318, IDO22055 , p. 52.

Barraclough, J. T., B. D. Lewis, and R. G. Jensen (USGS), 1981, Hydrologic Conditions at the Idaho National Engineering Laboratory, Idaho, Emphasis: 1974-1978, U.S. Geological Survey WaterResources Investigations/Open-File Report 81-526, IDO-22060, p. 116.

Barraclough, J. T., J. B. Robertson, V. J. Janzer, and L. G. Saindon (USGS), 1976, Hydrology of the Solid Waste Burial Ground, as Related to the Potential Migration of Radionuclides, Idaho National Engineering Laboratory, U.S. Geological Survey Open-File Report 76-471, p. 195, IDO-22056.

Bartholomay, R. C. et al., 1998. Hydrologic Conditions and Distribution of Selected Radiochemical and Chemical Constituents in Water, Snake River Plain Aquifer Idaho National Engineering and Environmental Laboratory (1996-1998).

Bartholomay, R. C., B. J. Tucker, L. C. Davis, and M. R. Greene (USGS), 2000, Hydrologic Conditions And Distribution Of Selected Constituents In Water, Snake River Plain Aquifer, Idaho National Engineering And Environmental Laboratory, Idaho, 1996 Through 1998: U.S. Geological Survey, Water-Resources Investigations Report 00-4192 (DOE/ID-22167), p. 52.

Bennett, C. M. (USGS), 1986, Capacity of the Diversion Channel Below the Flood-Control Dam on the Big Lost River at the Idaho National Engineering Laboratory, Idaho, U.S. Geological Survey Water-Resources Investigations Report 86-4204, DOE/ID-22071, p. 29.

Crosthwaite, E. G., C.A. Thomas, and K. L. Dyer (USGS), 1970, Water Resources in the Big Lost River Basin, South-Central Idaho: U.S. Geological Survey Open-File Report 70-93, p. 109.

DEQ, 1997, Idaho Wellhead Protection Plan, Idaho Department of Environmental Quality, February 1997.

DEQ, 1999, Idaho 401 Guidance.

DEQ, 1999, Idaho Source Water Assessment Plan.

DOE, 1993, Groundwater Protection Management Program.

DOE (G. Sehlke and F. E. Bickford), 1993, Idaho National Engineering Laboratory Groundwater Monitoring Plan, DOE/ID-10441. 
DOE, 1994, Idaho National Engineering and Environmental Laboratory Groundwater Protection Plan, DOE/ID-10274.

DOE, 2002, Idaho National Engineering and Environmental Laboratory Groundwater Monitoring Plan Update, DOE/ID-11034.

EPA, 1996, “Safe Drinking Water Act,” P.L. 104-182, 40 CFR 141, 149.

EPA, 2000, Unified Federal Policy for a Watershed Approach to Federal Land and Resource Management; Notice; Federal Register Vol. 65, No. 202

EPA, 2002, Surf Your Watershed, http://www.epa.gov/surf/.

EPA Method 524.2 (revision 3), 1988 "Methods for the Determination of Organic Compounds in Drinking Water Environmental Monitoring Systems Laboratory," Office of Research and Development, U.S. Environmental Protection Agency, December 1988.

EPA, 1997, State Source Water Assessment and Protection Programs Final Guidance, U.S. Environmental Protection Agency, Office of Water, EPA- 816/R-97-009, April 1997.

Fritzen, Mary Jane (editor), 1991, Idaho Falls, City of Destiny, Bonneville County Historical Society.

Graham W. G. and J. J. Campbell, 1981, Idaho Ground Water Quality Plan, Idaho Department of Water Resources, Boise, Idaho.

Idaho Department of Water Resource, 1990, Water Rights Agreement Between the State of Idaho and the United State for the United States DOE.

IDAPA 58.01.8000-8999, “Idaho Regulations for Public Water Systems,” Idaho Administrative Procedures Act.

IDAPA 37.03.09, "State of Idaho Well Construction Standards Rules," Idaho Department of Water Resources.

Knobel, L. L. and L. J. Mann (USGS), 1988, Radionuclides in Groundwater at the Idaho National Engineering Laboratory, Idaho, DOE/ID-22077, U.S. Geological Survey Open-File Report 88-731, p. 43.

Lewis, B. D. and R. G. Jensen (USGS), 1984, Hydrologic Conditions at the Idaho National Engineering Laboratory, Idaho: 1979-1981 Update, U.S. Geological Survey, Open-File Report 84-230.

Lindholm, G. F. (USGS), 1996. Summary of the Snake River Plain Regional Aquifer-System Analysis in Idaho and Eastern Oregon, USGS Professional Paper 1408-A.

Mann, L. J. and L. D. Cecil (USGS), 1990, Tritium in Groundwater at the Idaho National Engineering Laboratory, Idaho, U.S. Geological Survey Water- Resources Investigations Report 90-4090, DOE/ID-22090, p. 35.

Mann, L. J. and L. L. Knobel (USGS), 1987, Purgeable Organic Compounds in Groundwater at the Idaho National Engineering Laboratory, Idaho, U.S. Geological Survey Open-File Report 87-766, DOE/ID-22074, December. 
Mann, L. J. and L. L. Knobel (USGS), 1988, Concentrations of Nine Trace Metals in Groundwater at the Idaho National Engineering Laboratory, Idaho, U.S. Geological Survey Open-File Report 88-332, DOE/ID-22075, May 1988.

Mann, L. J. (USGS), 1986, Hydraulic Properties of Rock Units and Chemical Quality of Water for INEL1: A 10,365-Foot Deep Test Hole Drilled at the Idaho National Engineering Laboratory, Idaho, U.S. Geological Survey Water-Resources Investigations Report 86-4020, IDO-22070, p. 29.

Mann, L. J., E. W. Chew, J. S. Morton, and R. B. Randolph (USGS), 1988, Iodine-129 in the Snake River Plain Aquifer at the Idaho National Engineering Laboratory, Idaho, U.S. Geological Survey Water-Resources Investigations Report 88-4165, DOE/ID-22076, p. 27.

Mundorff, M. J., E. G. Crosthwaite, and C. Kilburn (USGS), 1964, Groundwater for Irrigation in the Snake River Basin in Idaho, U.S. Geological Survey Water-Supply Paper 1654, p. 224.

Nace, R. L., M. Deutsch, and P. T. Voegeli (USGS), 1972, "Physical Environment of the National Reactor Testing Station - a Summary," U.S. Geological Survey Professional Paper 725-A.

Orr, B. R. and L. D. Cecil (USGS), 1991, Hydrologic Conditions and Distribution of Selected Chemical Constituents in Water, Snake River Plain Aquifer, Idaho National Engineering Laboratory, Idaho, 1986-1988, U.S. Geological Survey Water-Resources Investigations Report 91-4047, DOE/ID-22096, March 1991.

Pittman, J. R., R. G. Jensen, P. R. Fischer (USGS), 1988, Hydrologic Conditions at the Idaho National Engineering Laboratory, 1982 to 1985. USGS WRIR-89-4008, DOE/ID-22078, p. 79.

Robertson, J. B. (USGS), 1974, Digital Modeling of Radioactive and Chemical Water Transport in the Snake River Plain Aquifer at the National Reactor Testing Station, Idaho, IDO-22054, U.S. Geological Survey, Open-File Report.

Robertson, J. B., R. Schoen, and J. T. Barraclough (USGS), 1974, The Influence of Liquid Waste Disposal on the Geochemistry of Water at the National Reactor Testing Station, Idaho: 1952-1970, UGS Open-File Report OF 73-0238, IDO-22053.

Seaber, P. R., F. P. Kapinos, and G. L. Knapp, 1987, Hydrologic Unit Maps: U.S. Geological Survey Water-Supply Paper 2294, p. 63.

Sehlke, G. et al, (DOE) 1993, Idaho National Engineering and Environmental Laboratory Comprehensive Well Survey, DOE/ID-10402.

Stearns, H. T., L. Crandall, and W. G. Steward (USGS), 1938, Geology and Ground-water Resources of the Snake River Plain in Southeastern Idaho: U.S. Geological Survey Water-Supply Paper 774, p. 268.

Stone, M. A. J., L. J. Mann, and L. C. Kjelstrom, 1993, Statistical Summary of Streamflow Data for Selected Gaging Stations On and Near the Idaho National Engineering Laboratory, Idaho, Through September 1990, United States Geological Survey, Water Resources Investigations Report 92-4196, Boise, Idaho.

USGS, 1964, Mineral and Water Resources of Idaho, U.S. Government Printing Office, Washington, D.C. 
WEC, 1994, Final Remedial Investigation/Feasibility Study for the Exterior Industrial Waste Ditch Operable Unit 8-07, Volumes 1 and 2, Naval Reactors Facility, Idaho Falls, Idaho, September 1994.

WEC, 1997, NRF Comprehensive Remedial Investigation/Feasibility Study, Waste Area Group 8, Volumes 1, 2, and 3, Naval Reactors Facility, Idaho Falls, Idaho, October 1997. 


\section{APPENDIX A}

Facility-Specific Wellhead Protection Area Maps 



\section{APPENDIX A}

\section{Facility-Specific Wellhead Protection Area Maps}

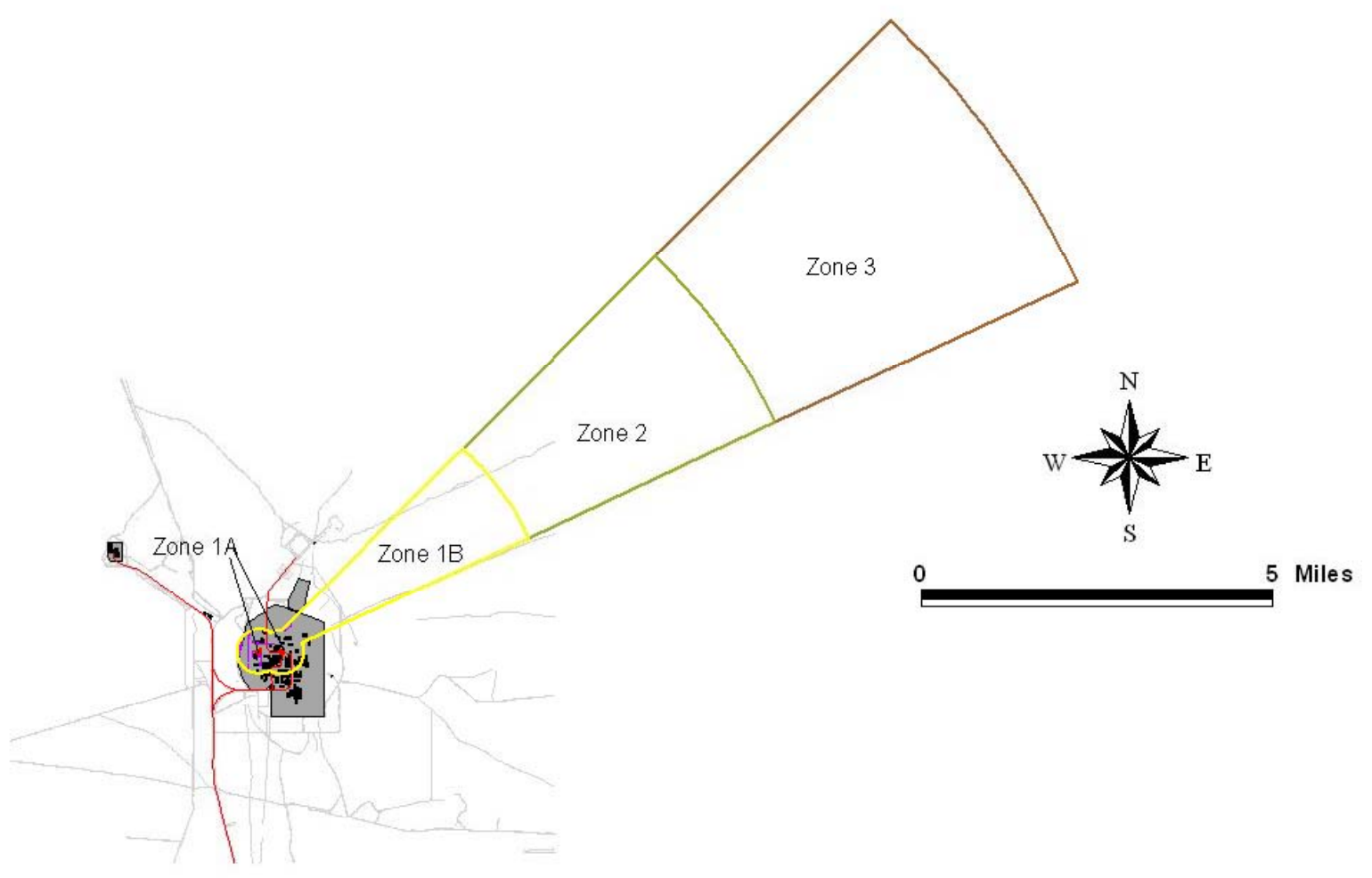

Figure A-1. Argonne National Laboratory-West wellhead protection area - intercepts. 


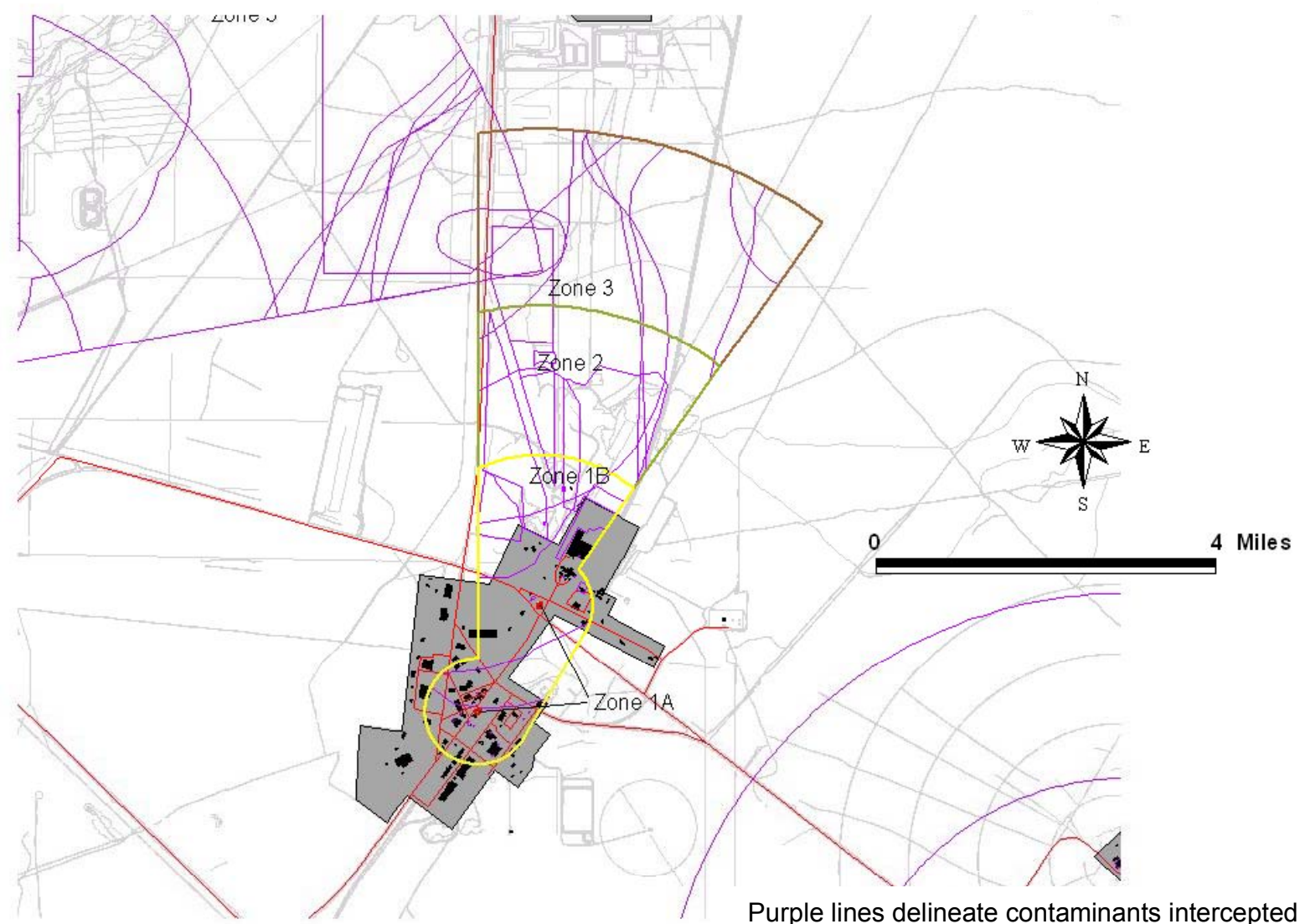

Figure A-2. Central Facilities Area wellhead protection area - intercepts. 


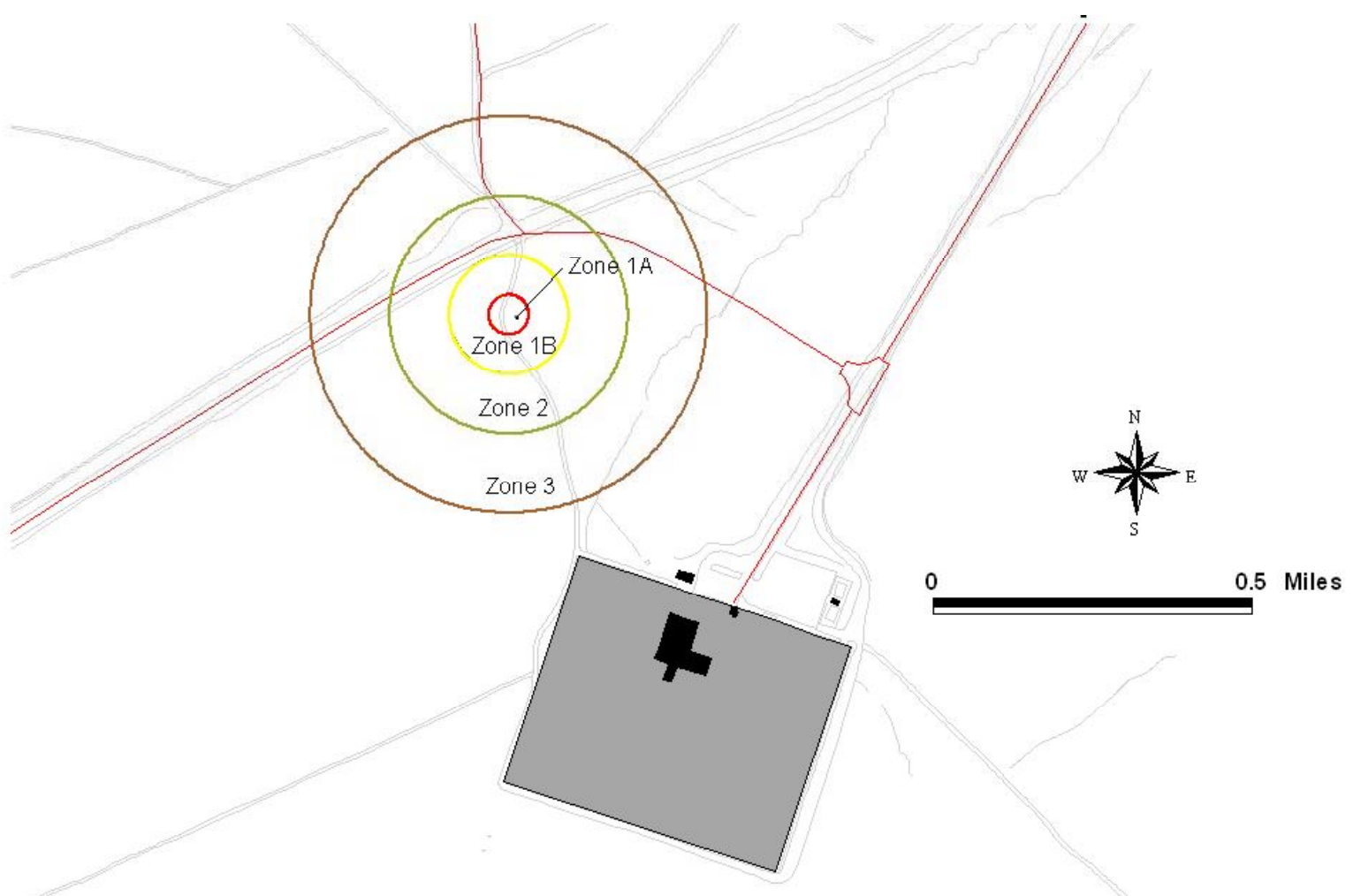

Figure A-3. Experimental Breeder Reactor-1 wellhead protection area - intercepts. 


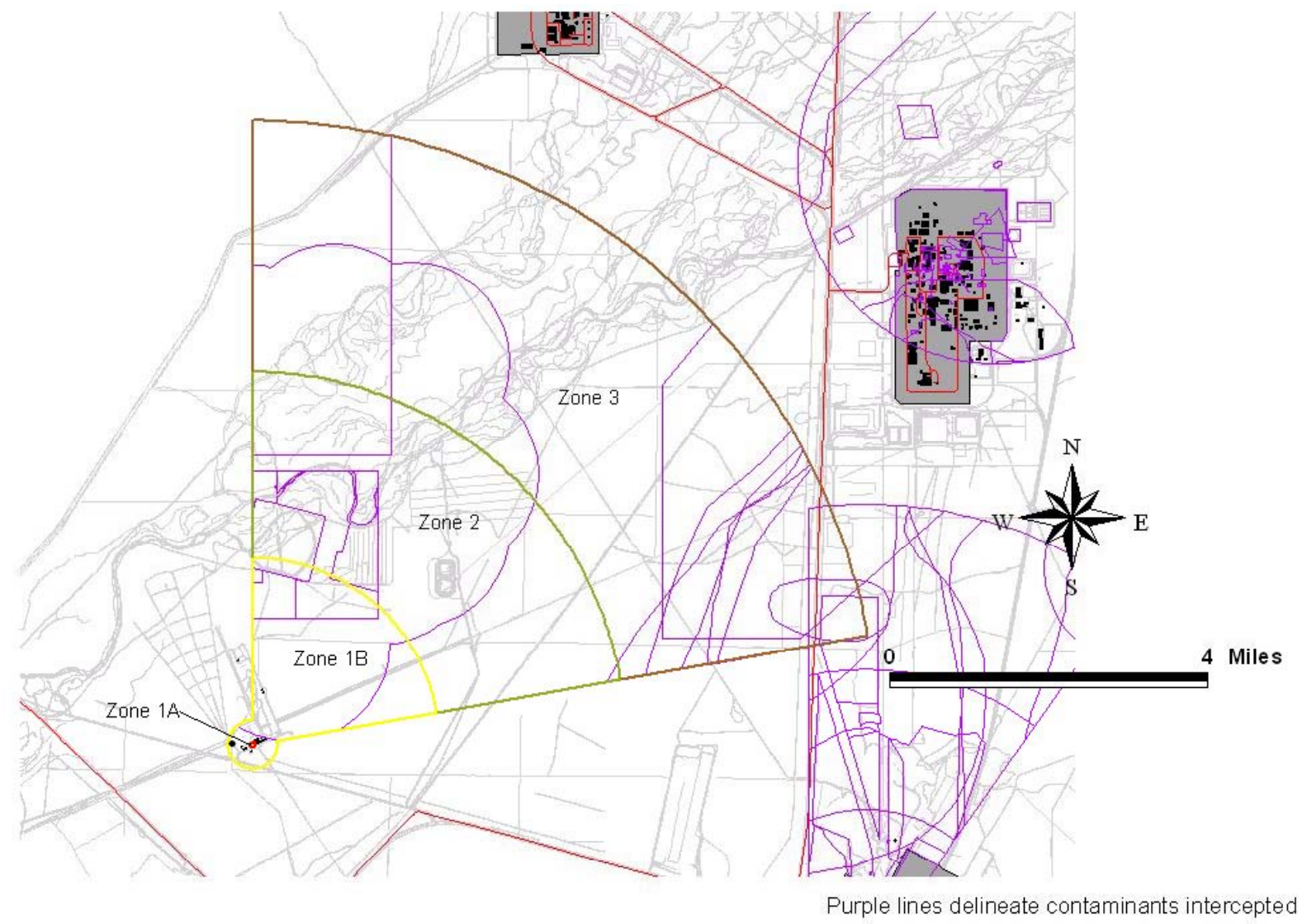

Figure A-4. Gun Range wellhead protection area - intercepts. 


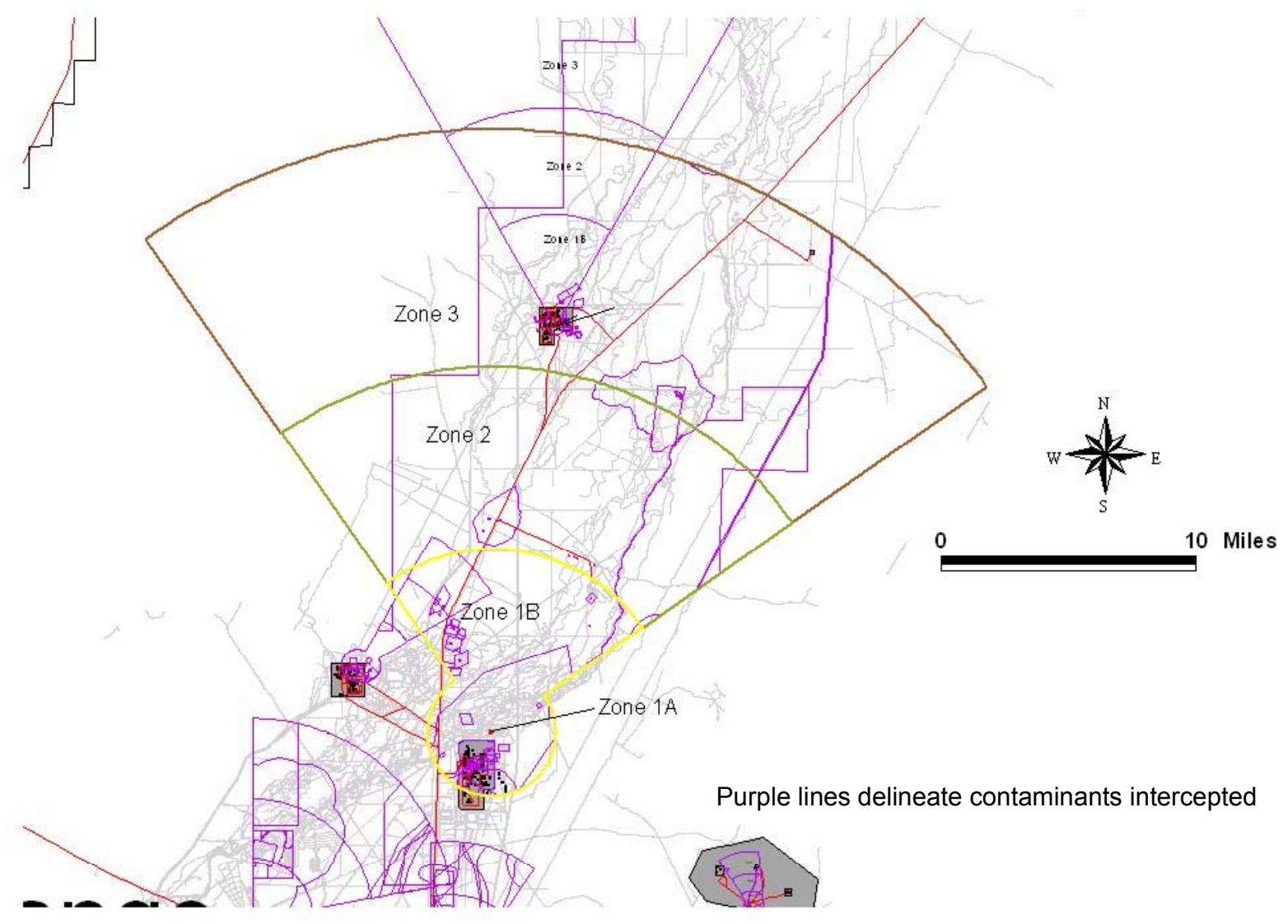

Figure A-5. Idaho Nuclear Technology and Engineering Center wellhead protection area - intercepts 


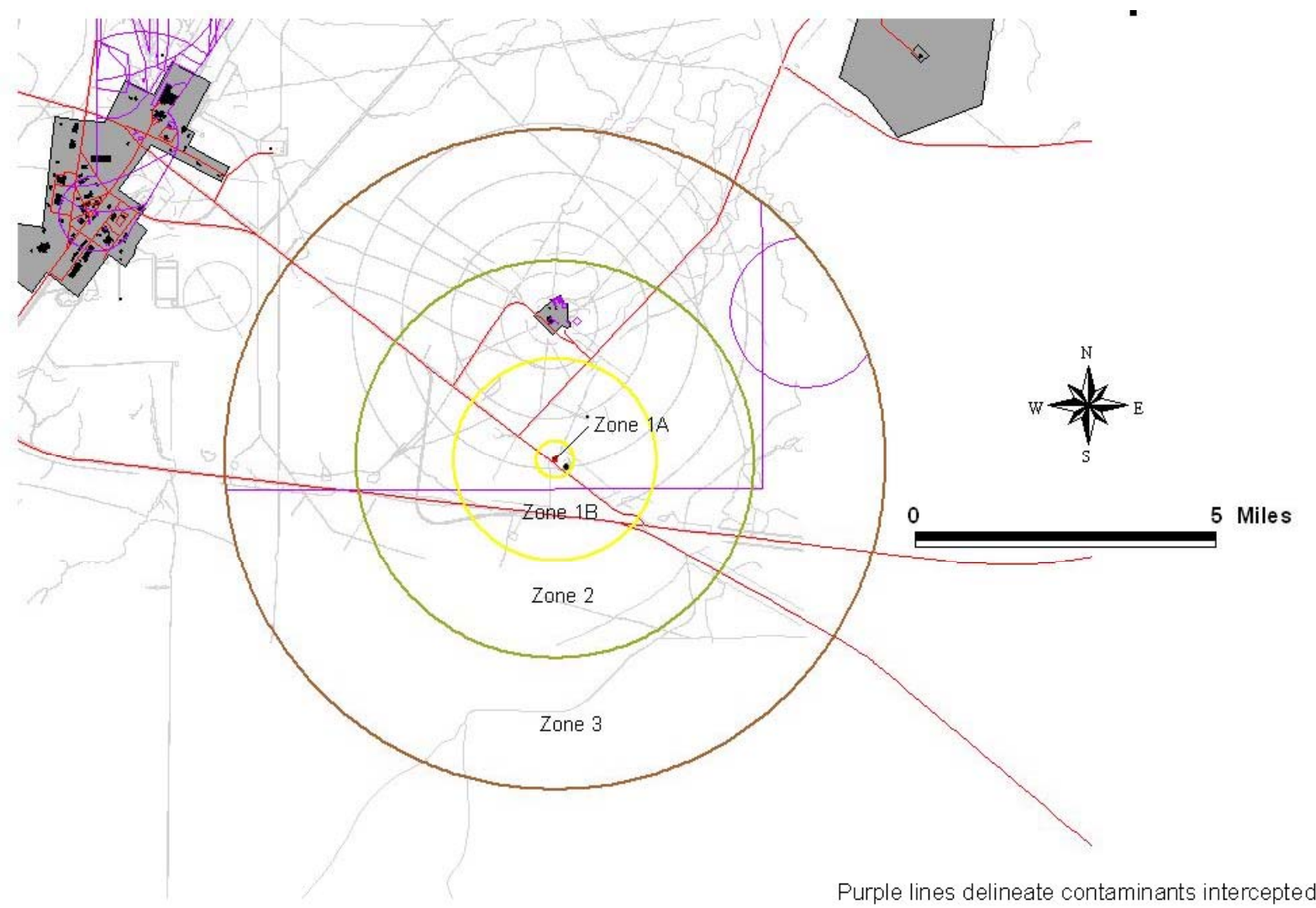

Figure A-6. Main Gate wellhead protection area - intercepts 


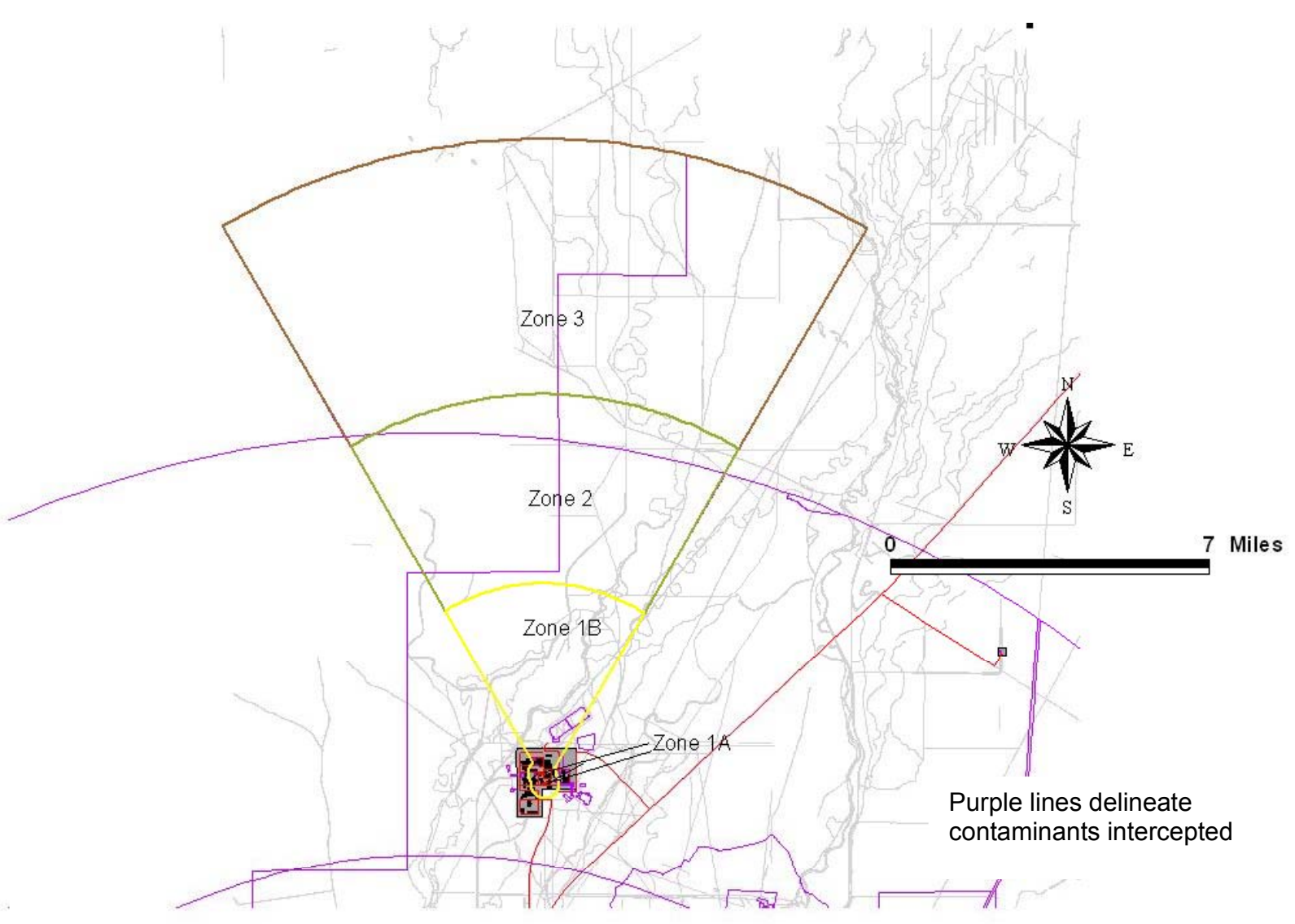

Figure A-7. Naval Reactors Facility wellhead protection area - intercepts 


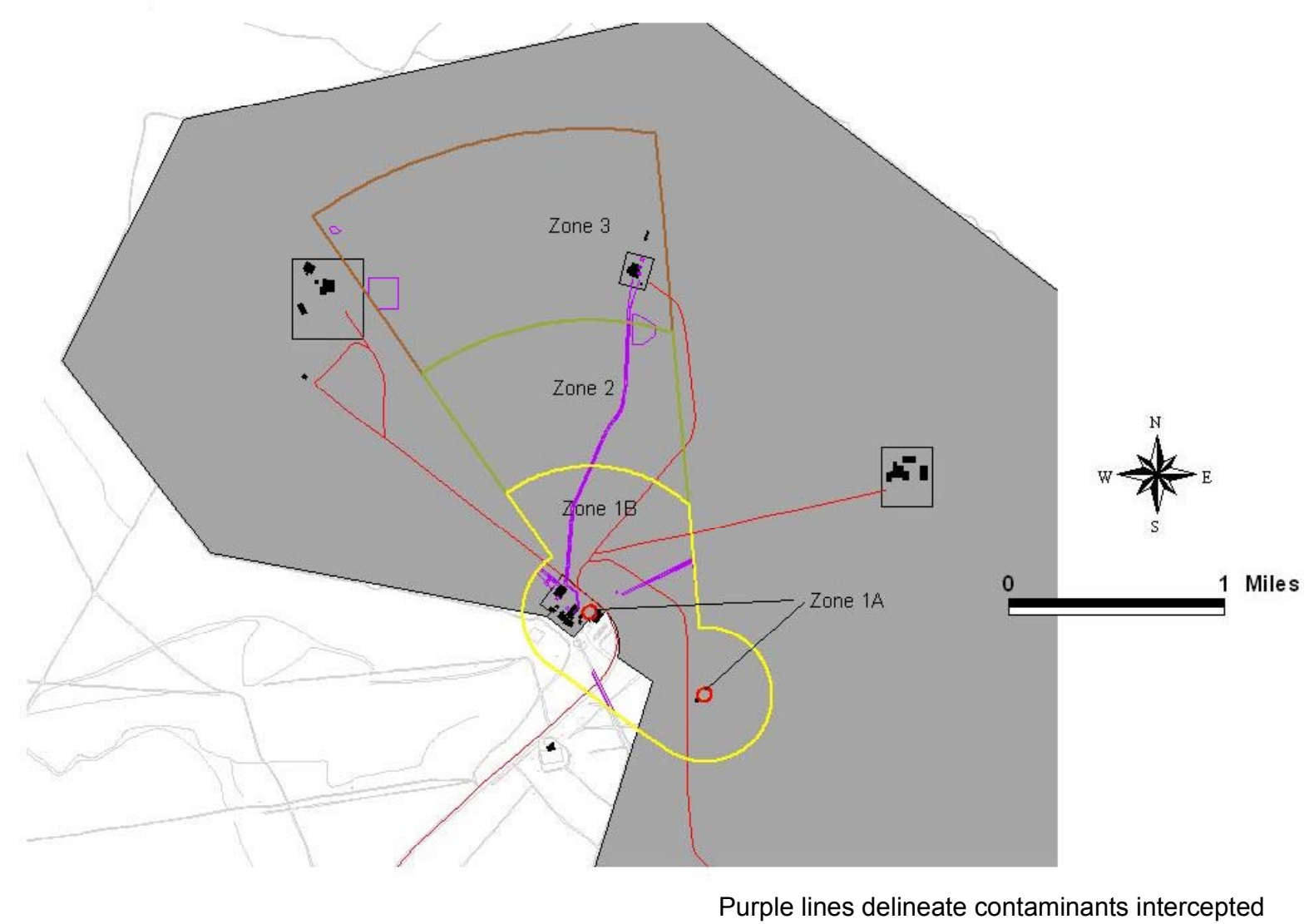

Figure A-8. Power Burst Facility wellhead protection area - intercepts. 


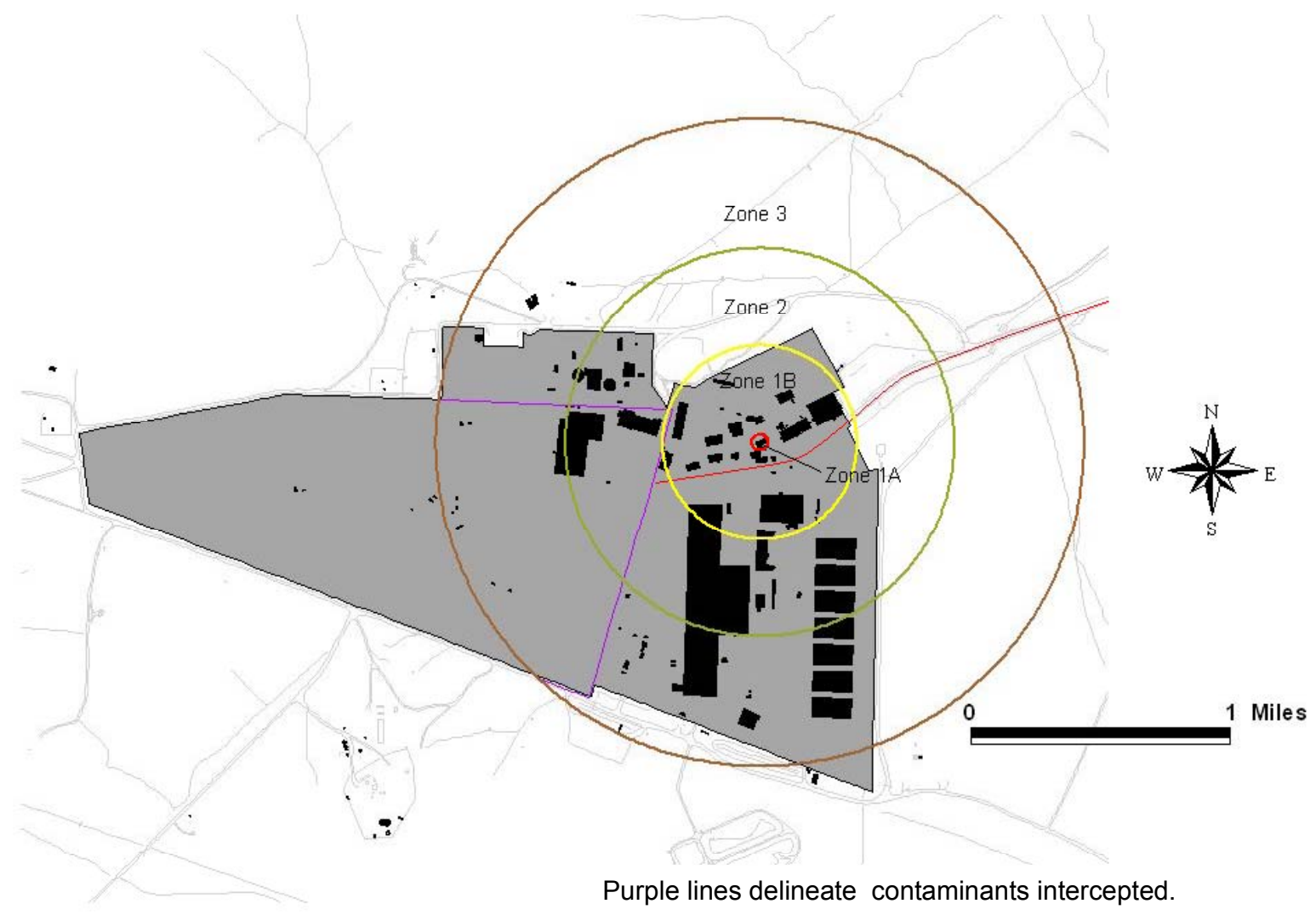

Figure A-9. Radioactive Waste Management Complex wellhead protection area - intercepts. 


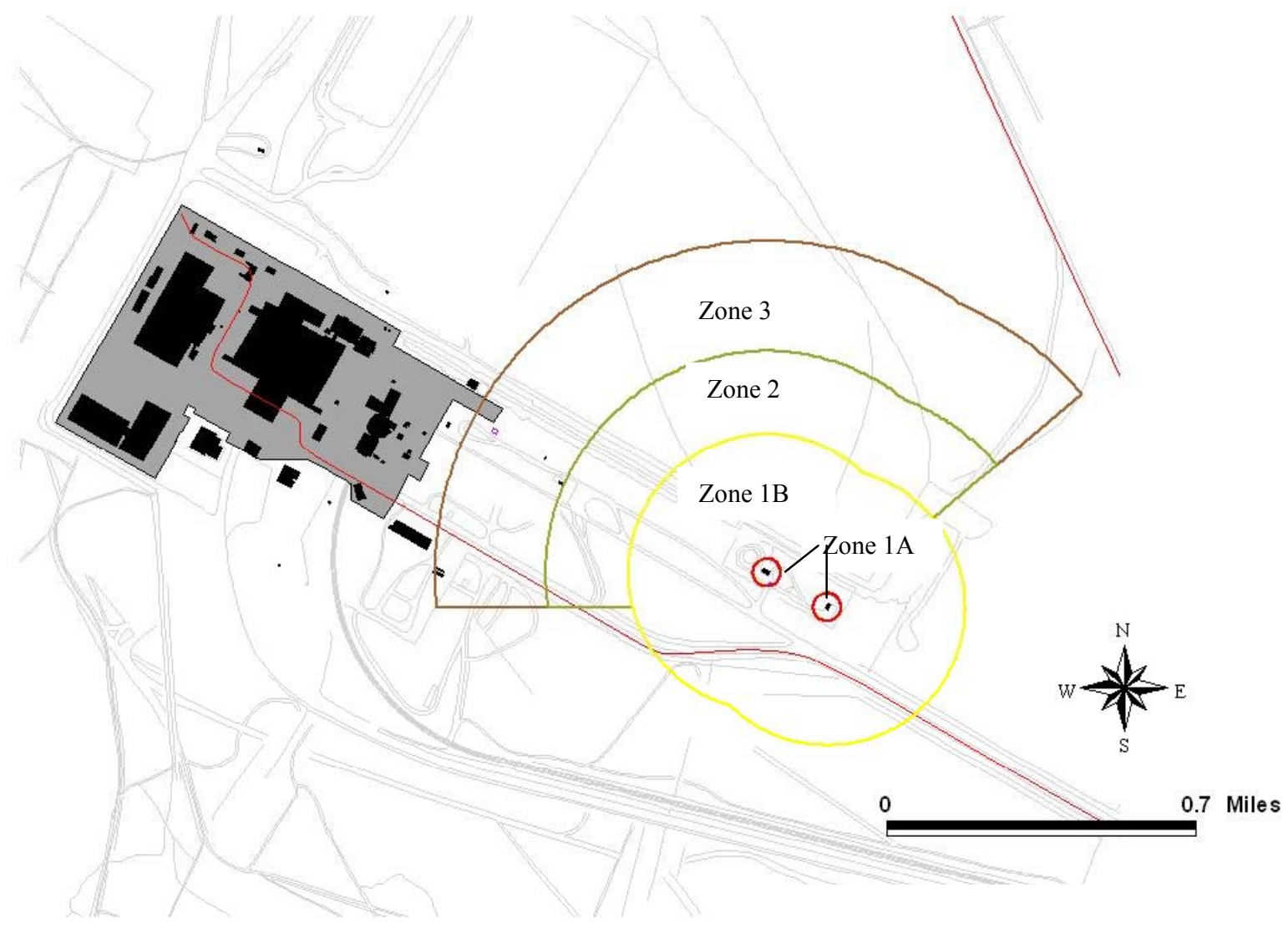

Figure A-10. Test Area North/Contained Test Facility wellhead protection area - intercepts. 


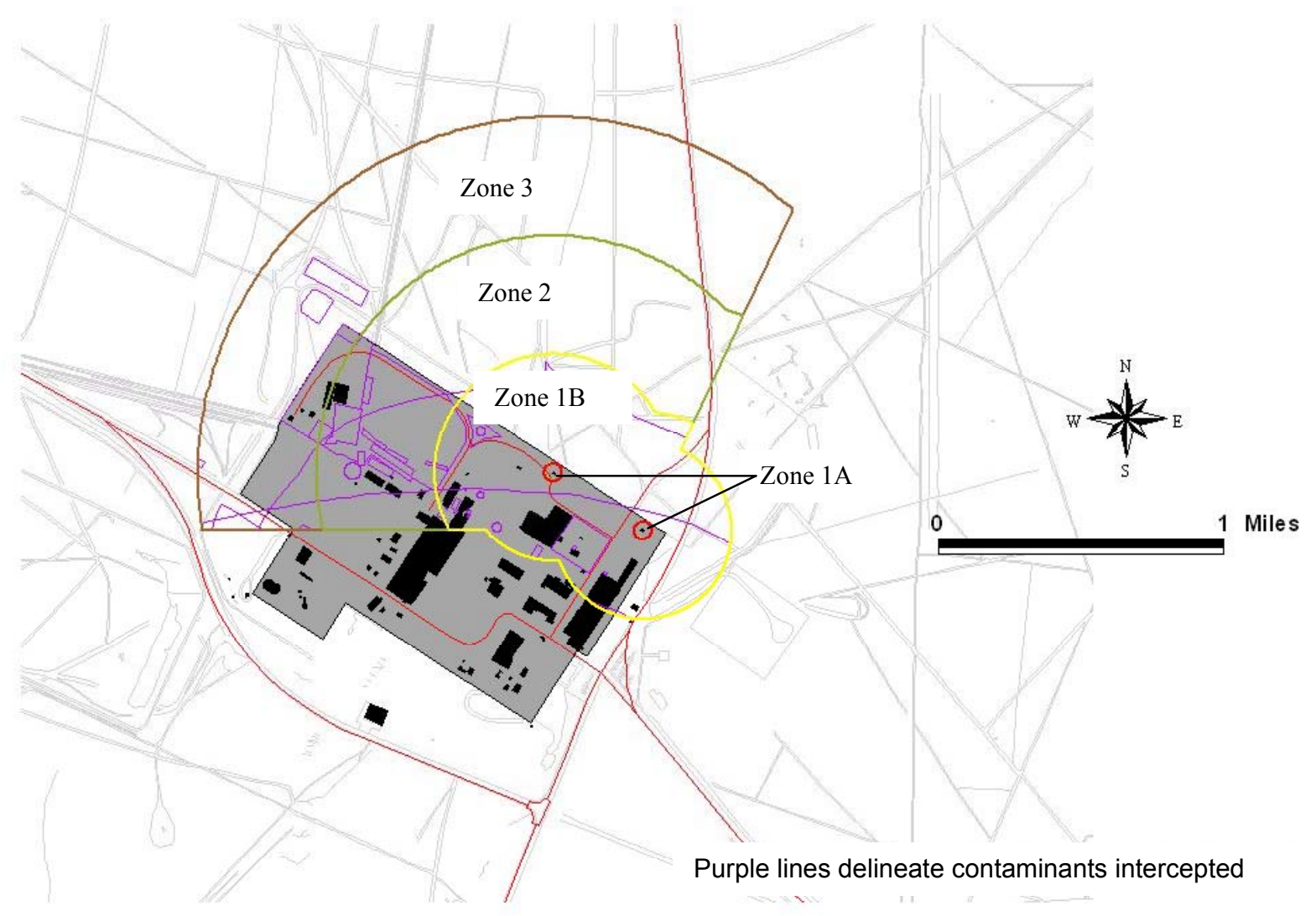

Figure A-11. Test Area North /Technical Support Facility wellhead protection area - intercepts. 


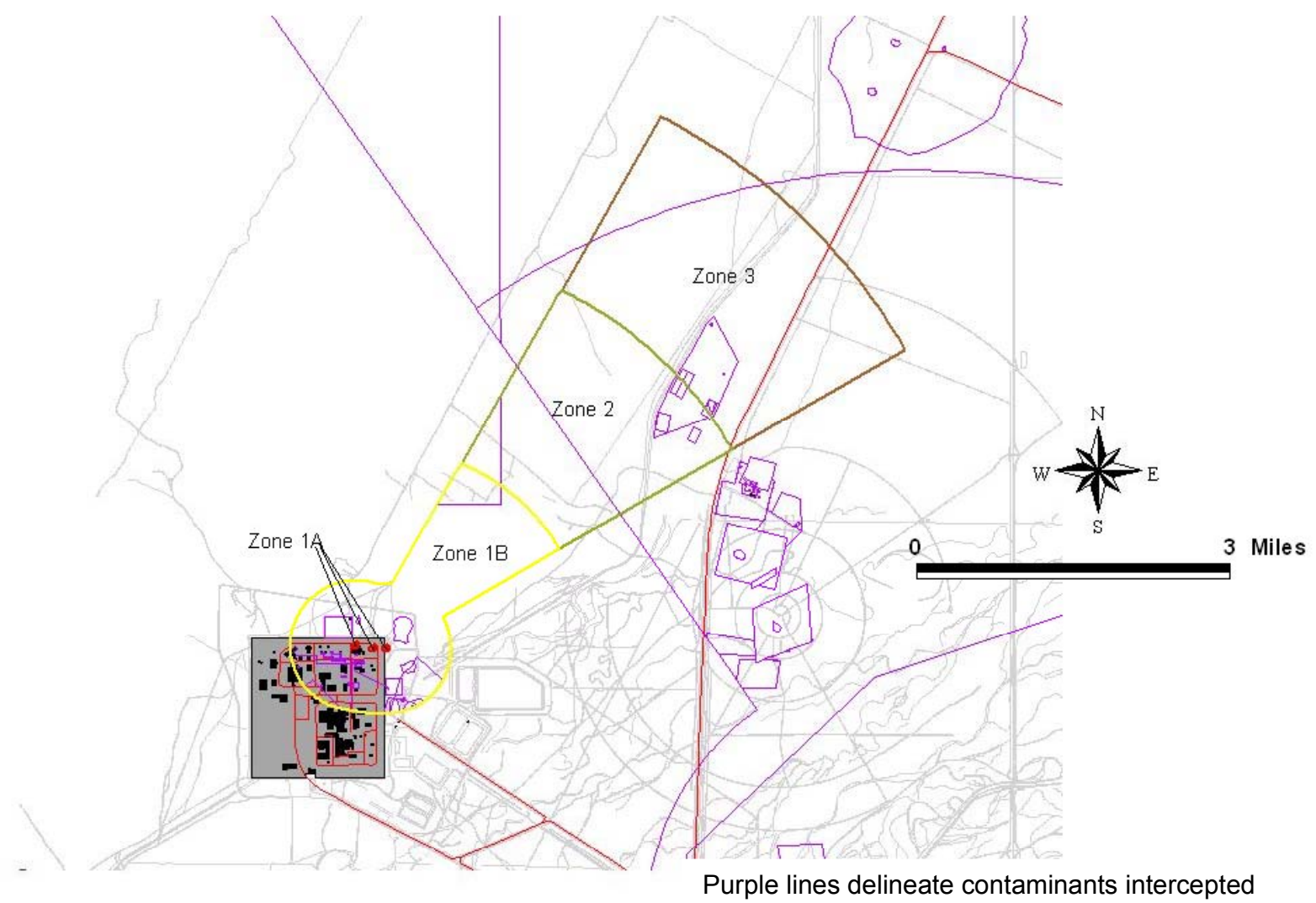

Figure A-12. Test Reactor Area wellhead protection area - intercepts. 


\section{APPENDIX B}

Summary of Potential Contaminant Sources Within INEEL Wellhead Protection Areas 



\section{APPENDIX B}

\section{Summary of Potential Contaminant Sources Within INEEL Wellhead Protection Areas}

Table B-1. Argonne National Laboratory-West.

\begin{tabular}{|c|c|c|c|c|c|c|c|}
\hline \multirow[b]{2}{*}{ Facility } & \multirow[b]{2}{*}{ Well $^{\mathrm{a}}$} & \multirow[b]{2}{*}{ Zone } & \multirow[b]{2}{*}{ Sitecode } & \multicolumn{4}{|c|}{ Potential Contaminant } \\
\hline & & & & & GIS 1 & GIS 2 & GIS 3 \\
\hline ANL-W & EBR-II \#2 & Zone $1 \mathrm{~A}$ & $\begin{array}{l}\text { ANL-01 } \\
\text { (Ditch A only) }\end{array}$ & Inorganics & Mercury & & \\
\hline ANL-W & & Zone 1B & ANL-01 & Inorganics and Rad & $\begin{array}{l}\text { Chromium, Mercury, } \\
\text { Selenium, Zinc, Cs-137 }\end{array}$ & NA & NA \\
\hline ANL-W & & Zone 1B & ANL-01A & Inorganics & Chromium, Mercury & NA & NA \\
\hline ANL-W & & Zone 1B & ANL-09 & $\mathrm{Rad}$ & Cs-137 & NA & NA \\
\hline ANL-W & & Zone 1B & ANL-04 & Inorganics & Mercury & NA & NA \\
\hline ANL-W & & Zone 1B & ANL-35 & Inorganics & Silver & NA & NA \\
\hline
\end{tabular}


Table B-2. Central Facilities Area.

\begin{tabular}{|c|c|c|c|c|c|c|c|c|}
\hline Facility & Well $^{\mathrm{a}}$ & Zone & Sitecode & & Potential Contam & inant & & \\
\hline CFA & & Zone 1A & & Chloride & Iodine-129 & & & \\
\hline CFA & & Zone $1 \mathrm{~A}$ & & Down Range ${ }^{\mathrm{b}}$ Area & Uncleared & Down Range Area & & \\
\hline CFA & CFA \#2 & Zone 1B & $\begin{array}{l}\text { CFA } \\
\text { Landfill II }\end{array}$ & $\begin{array}{l}\text { Volatile organic } \\
\text { compounds, metals, } \\
\text { total dissolved solids, } \\
\text { anions }\end{array}$ & & & & \\
\hline CFA & & Zone 1B & CFA-02 & Organics & $\begin{array}{l}\text { Acetone, Benzene, 2-Butanone, Carbon } \\
\text { Disulfide, Ethylbenzene, Methylene } \\
\text { chloride, Tetrachloroethene, Xylene, } \\
\text { Bis(2-ethylhexyl)phthalate, 1,1- } \\
\text { Dichloroethene, Methane, } \\
\text { Benzo(a)anthracene, Benzo(a)pyrene, } \\
\text { Chrysene, Dibenzo(a)anthracene }\end{array}$ & $\begin{array}{l}\text { Indeno(1,2,3- } \\
\text { cd)pyrene, }\end{array}$ & NA & \\
\hline CFA & & Zone 1B & CFA-02 & Chloride & Iodine-129 & Strontium-90 & & \\
\hline CFA & & Zone 1B & CFA-02 & Down Range Area & Uncleared & Down Range Area & & \\
\hline CFA & & Zone 1B & CFA-06 & Inorganics & Arsenic, Lead, Nickel & NA & NA & \\
\hline CFA & & Zone 1B & CFA-06 & Chloride & Iodine-129 & & & \\
\hline CFA & & Zone 1B & CFA-06 & Down Range Area & Uncleared & Down Range Area & & \\
\hline CFA & & Zone 1B & CFA-07 & $\begin{array}{l}\text { Metals, Organics, and } \\
\text { Rad }\end{array}$ & NA & NA & NA & \\
\hline
\end{tabular}


Table B-2. (continued).

\begin{tabular}{|c|c|c|c|c|c|c|c|}
\hline Facility & Well ${ }^{\mathrm{a}}$ & Zone & Sitecode & & & Potential Contaminant & \\
\hline CFA & & Zone 1B & CFA-07 & Down Range Area & Uncleared & Down Range Area & \\
\hline CFA & & Zone 1B & CFA-09 & Chloride & Iodine-129 & & \\
\hline CFA & & Zone 1B & CFA-09 & Down Range Area & Uncleared & Down Range Area & \\
\hline CFA & & Zone 1B & CFA-11 & Ordnance & NA & NA & NA \\
\hline CFA & & Zone 1B & CFA-11 & Chloride & Iodine-129 & & \\
\hline CFA & & Zone 1B & CFA-11 & Down Range Area & Uncleared & Down Range Area & \\
\hline CFA & & Zone 1B & CFA-13 & Fuel Oil & NA & NA & NA \\
\hline CFA & & Zone 1B & CFA-13 & Chloride & & & \\
\hline CFA & & Zone 1B & CFA-13 & Down Range Area & Uncleared & Down Range Area & \\
\hline CFA & & Zone 1B & CFA-14 & Chloride & & & \\
\hline CFA & & Zone 1B & CFA-14 & Down Range Area & Uncleared & Down Range Area & \\
\hline CFA & & Zone 1B & CFA-16 & Chloride & & & \\
\hline CFA & & Zone 1B & CFA-16 & Down Range Area & Uncleared & Down Range Area & \\
\hline CFA & & Zone 1B & CFA-16 & Down Range Area & Uncleared & Down Range Area & \\
\hline CFA & & Zone 1B & CFA-19 & Fuel Oil & NA & NA & NA \\
\hline CFA & & Zone 1B & CFA-19 & Chloride & & & \\
\hline CFA & & Zone 1B & CFA-19 & Down Range Area & Uncleared & Down Range Area & \\
\hline CFA & & Zone 1B & CFA-20 & Fuel Oil & NA & NA & NA \\
\hline CFA & & Zone 1B & CFA-20 & Chloride & & & \\
\hline CFA & & Zone 1B & CFA-20 & Down Range Area & Uncleared & Down Range Area & \\
\hline CFA & & Zone 1B & CFA-21 & Fuel Oil & NA & NA & NA \\
\hline CFA & & Zone 1B & CFA-21 & Chloride & & & \\
\hline CFA & & Zone 1B & CFA-21 & Down Range Area & Uncleared & Down Range Area & \\
\hline CFA & & Zone 1B & CFA-22 & Fuel Oil & NA & NA & NA \\
\hline CFA & & Zone 1B & CFA-22 & Chloride & & & \\
\hline CFA & & Zone 1B & CFA-22 & Down Range Area & Uncleared & Down Range Area & \\
\hline CFA & & Zone 1B & CFA-23 & Fuel Oil & NA & NA & NA \\
\hline
\end{tabular}


Table B-2. (continued).

\begin{tabular}{|c|c|c|c|c|c|c|c|}
\hline Facility & Well $^{\mathrm{a}}$ & Zone & Sitecode & & & Potential Contaminant & \\
\hline CFA & & Zone 1B & CFA-23 & Chloride & & & \\
\hline CFA & & Zone 1B & CFA-23 & Down Range Area & Uncleared & Down Range Area & \\
\hline CFA & & Zone 1B & CFA-24 & Fuel Oil & NA & NA & NA \\
\hline CFA & & Zone 1B & CFA-24 & Chloride & & & \\
\hline CFA & & Zone 1B & CFA-24 & Down Range Area & Uncleared & Down Range Area & \\
\hline CFA & & Zone 1B & CFA-25 & Fuel Oil & NA & NA & NA \\
\hline CFA & & Zone 1B & CFA-25 & Chloride & Iodine-129 & & \\
\hline CFA & & Zone 1B & CFA-25 & Down Range Area & Uncleared & Down Range Area & \\
\hline CFA & & Zone 1B & CFA-27 & Fuel Oil & NA & NA & NA \\
\hline CFA & & Zone 1B & CFA-27 & Chloride & Iodine-129 & & \\
\hline CFA & & Zone 1B & CFA-27 & Down Range Area & Uncleared & Down Range Area & \\
\hline CFA & & Zone 1B & CFA-29 & Fuel Oil & NA & NA & NA \\
\hline CFA & & Zone 1B & CFA-29 & Chloride & & & \\
\hline CFA & & Zone 1B & CFA-29 & Down Range Area & Uncleared & Down Range Area & \\
\hline CFA & & Zone 1B & CFA-30 & Fuel Oil & NA & NA & NA \\
\hline CFA & & Zone 1B & CFA-30 & Chloride & & & \\
\hline CFA & & Zone 1B & CFA-30 & Down Range Area & Uncleared & Down Range Area & \\
\hline CFA & & Zone 1B & CFA-32 & Fuel Oil & NA & NA & NA \\
\hline CFA & & Zone 1B & CFA-32 & Chloride & & & \\
\hline CFA & & Zone 1B & CFA-32 & Down Range Area & Uncleared & Down Range Area & \\
\hline CFA & & Zone 1B & CFA-36 & Fuel Oil & NA & NA & NA \\
\hline CFA & & Zone 1B & CFA-36 & Chloride & & & \\
\hline CFA & & Zone 1B & CFA-36 & Down Range Area & Uncleared & Down Range Area & \\
\hline CFA & & Zone 1B & CFA-37 & Fuel Oil & NA & NA & NA \\
\hline CFA & & Zone 1B & CFA-37 & Chloride & Iodine-129 & & \\
\hline CFA & & Zone 1B & CFA-37 & Down Range Area & Uncleared & Down Range Area & \\
\hline
\end{tabular}


Table B-2. (continued).

\begin{tabular}{|c|c|c|c|c|c|c|c|c|}
\hline Facility & Well $^{\mathrm{a}}$ & Zone & Sitecode & & Potential Co & inant & & \\
\hline CFA & & Zone 1B & CFA-44 & Inorganics & $\begin{array}{l}\text { Chromium, Lead, Mercury, Nickel, } \\
\text { Silver, Vanadium, Zinc }\end{array}$ & NA & NA & \\
\hline CFA & & Zone 1B & CFA-44 & Chloride & & & & \\
\hline CFA & & Zone 1B & CFA-44 & Down Range Area & Uncleared & Down Range Area & & \\
\hline CFA & & Zone 1B & CFA-45 & Fuel Oil & NA & NA & NA & \\
\hline CFA & & Zone 1B & CFA-45 & Chloride & Iodine-129 & & & \\
\hline CFA & & Zone 1B & CFA-46 & Chloride & & & & \\
\hline CFA & & Zone 1B & CFA-46 & Down Range Area & Uncleared & Down Range Area & & \\
\hline CFA & & Zone 1B & CFA- 48 & Chloride & Iodine-129 & & & \\
\hline CFA & & Zone 1B & CFA-48 & Down Range Area & Uncleared & Down Range Area & & \\
\hline CFA & & Zone 1B & CFA-51 & Chloride & & & & \\
\hline CFA & & Zone 1B & CFA-51 & Down Range Area & Uncleared & Down Range Area & & \\
\hline CFA & & Zone 1B & CFA-52 & Fuel Oil & NA & NA & NA & \\
\hline CFA & & Zone 1B & CFA-52 & Chloride & & & & \\
\hline CFA & & Zone 1B & CFA-52 & Down Range Area & Uncleared & Down Range Area & & \\
\hline CFA & & Zone 1B & & & & & & $\begin{array}{l}\text { Landfill V, } \\
\text { Commercial \& } \\
\text { Industrial Waste }\end{array}$ \\
\hline CFA & & Zone 1B & & & & & & $\begin{array}{l}\text { Land Fill IV, Bulky } \\
\text { Waste Pit }\end{array}$ \\
\hline
\end{tabular}


Table B-2. (continued).

\begin{tabular}{|c|c|c|c|c|c|c|c|c|}
\hline Facility & Well $^{\mathrm{a}}$ & Zone & Sitecode & & Potential Contar & inant & & \\
\hline CFA & & Zone 1B & & Down Range Area & Uncleared & Down Range Area & & \\
\hline CFA & & Zone 1B & & CFA GRAVEL PIT & CLOSE AREA & $\begin{array}{l}\text { Cleared Ordnance } \\
\text { Area }\end{array}$ & & \\
\hline CFA & & Zone 2 & & & & & & $\begin{array}{l}\text { Landfill V, } \\
\text { Commercial \& } \\
\text { Industrial Waste }\end{array}$ \\
\hline CFA & & Zone 2 & & & & & & $\begin{array}{l}\text { Land Fill IV, Bulky } \\
\text { Waste Pit }\end{array}$ \\
\hline CFA & & Zone 2 & & & & & & $\begin{array}{l}\text { Landfill V, } \\
\text { Overburden Area }\end{array}$ \\
\hline CFA & & Zone 2 & & & & & & $\begin{array}{l}\text { Overburden Stock } \\
\text { Pile }\end{array}$ \\
\hline CFA & & Zone 2 & & Chloride & Iodine-129 & Strontium-90 & & \\
\hline CFA & & Zone 2 & & Down Range Area & Uncleared & Down Range Area & & \\
\hline CFA & & Zone 3 & CPP-95 & $\operatorname{Rad}$ & $\begin{array}{l}\text { Americium-241, Cesium-134, Cesium- } \\
\text { 137, Potassium-40, Plutonium-238, } \\
\text { Plutonium-239/240, Strontium-90, } \\
\text { Uranium-233, Uranium-234, Uranium- } \\
235\end{array}$ & NA & NA & \\
\hline CFA & & Zone 3 & CPP-95 & Chloride & Iodine-129 & Strontium-90 & & \\
\hline CFA & & Zone 3 & CPP-95 & Down Range Area & Uncleared & Down Range Area & & \\
\hline CFA & & Zone 3 & & & & & & $\begin{array}{l}\text { Landfill V, } \\
\text { Commercial \& } \\
\text { Industrial Waste }\end{array}$ \\
\hline CFA & & Zone 3 & & Chloride & Iodine-129 & & & \\
\hline CFA & & Zone 3 & & Down Range Area & Uncleared & Down Range Area & & \\
\hline CFA & & Zone 3 & & CRATERS EAST & Assessed & Identified UXO Area & & \\
\hline
\end{tabular}


Table B-3. Experimental Breeder Reactor-I

\begin{tabular}{llllll} 
& & & \multicolumn{2}{c}{ Potential Contaminant } \\
\cline { 4 - 5 } Facility & Well & Zone & Sitecode & GIS 1 & GIS 2 \\
\hline EBR-I & Zone 1A & Down Range ${ }^{\mathrm{b}}$ Area & Uncleared & Down Range Area \\
EBR-I & Zone 1B & Down Range Area & Uncleared & Down Range Area \\
EBR-I & Zone 2 & Down Range Area & Uncleared & Down Range Area \\
EBR-I & Zone 3 & & Down Range Area & Uncleared & Down Range Area
\end{tabular}

a. The well column is blank if the information applies to all wells. The well number is specified if information is specific to that well.

b. Downrange means out of capture zone. 
Table B-4. Gun Range.

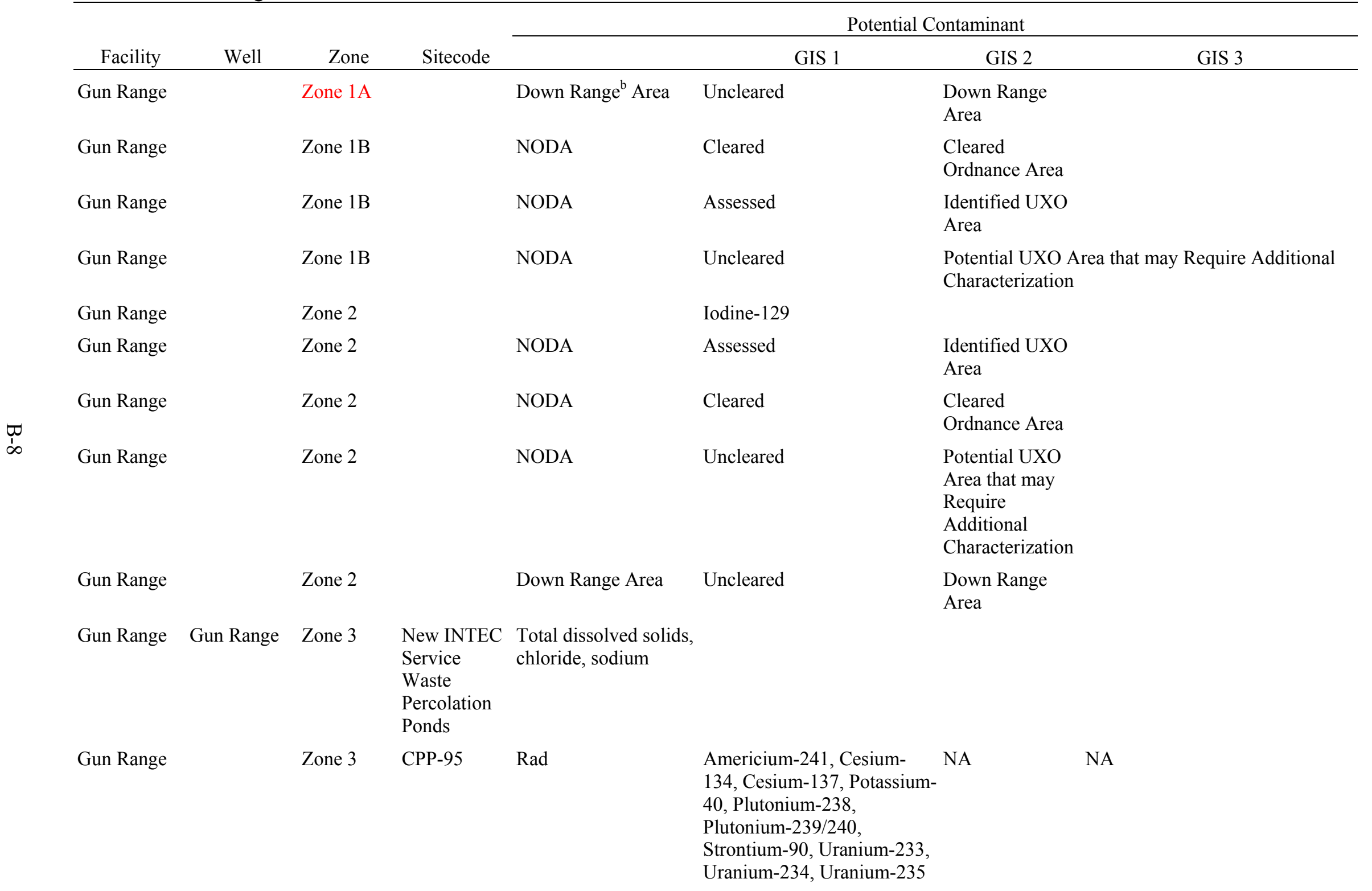


Table B-4. (continued).

\begin{tabular}{|c|c|c|c|c|c|c|c|}
\hline \multirow[b]{2}{*}{ Facility } & \multirow[b]{2}{*}{ Well } & \multirow[b]{2}{*}{ Zone } & \multirow[b]{2}{*}{ Sitecode } & \multicolumn{4}{|c|}{ Potential Contaminant } \\
\hline & & & & & GIS 1 & GIS 2 & GIS 3 \\
\hline Gun Range & & Zone 3 & & & & & Chromium \\
\hline Gun Range & & Zone 3 & СРP-95 & & & Strontium-90 & \\
\hline Gun Range & & Zone 3 & CPP-95 & Chloride & Iodine-129 & Strontium-90 & \\
\hline Gun Range & & Zone 3 & & & Iodine-129 & & \\
\hline Gun Range & & Zone 3 & & Chloride & Iodine-129 & Strontium-90 & \\
\hline Gun Range & & Zone 3 & & Down Range Area & Uncleared & $\begin{array}{l}\text { Down Range } \\
\text { Area }\end{array}$ & \\
\hline Gun Range & & Zone 3 & & NODA & Assessed & $\begin{array}{l}\text { Identified UXO } \\
\text { Area }\end{array}$ & \\
\hline Gun Range & & Zone 3 & CPP-95 & Down Range Area & Uncleared & $\begin{array}{l}\text { Down Range } \\
\text { Area }\end{array}$ & \\
\hline Gun Range & & Zone 3 & CPP-95 & Down Range Area & Uncleared & $\begin{array}{l}\text { Down Range } \\
\text { Area }\end{array}$ & \\
\hline Gun Range & & Zone 3 & & Down Range Area & Uncleared & $\begin{array}{l}\text { Down Range } \\
\text { Area }\end{array}$ & \\
\hline
\end{tabular}

a. The well column is blank if the information applies to all wells. The well number is specified if information is specific to that well.

b. Downrange means out of capture zone. 
Table B-5. Idaho Nuclear Technology and Engineering Center.

\begin{tabular}{|c|c|c|c|c|c|c|c|}
\hline \multirow[b]{2}{*}{ Facility } & \multirow[b]{2}{*}{ Well $^{\mathrm{a}}$} & \multirow[b]{2}{*}{ Zone } & \multirow[b]{2}{*}{ Sitecode } & \multicolumn{4}{|c|}{ Potential Contaminant } \\
\hline & & & & & GIS 1 & GIS 2 & GIS 3 \\
\hline INTEC & & Zone $1 \mathrm{~A}$ & CPP-95 & $\operatorname{Rad}$ & $\begin{array}{l}\text { Americium-241, } \\
\text { Cesium-134, Cesium- } \\
\text { 137, Potassium-40, } \\
\text { Plutonium-238, } \\
\text { Plutonium-239/240, } \\
\text { Strontium-90, Uranium- } \\
\text { 233, Uranium-234, } \\
\text { Uranium-235 }\end{array}$ & NA & NA \\
\hline INTEC & & Zone $1 \mathrm{~A}$ & СРP-95 & Down Range ${ }^{\mathrm{b}}$ Area & Uncleared & Down Range Area & \\
\hline INTEC & & Zone 1B & $\begin{array}{l}\text { CPP-23 } \\
\text { Injection } \\
\text { Well }\end{array}$ & Radionuclides, mercury & & & \\
\hline INTEC & & Zone 1B & $\begin{array}{l}\text { CPP-96 Tank } \\
\text { Farm Soils }\end{array}$ & $\begin{array}{l}\text { Radionuclides, mercury, } \\
\text { nitrate }\end{array}$ & & & \\
\hline INTEC & & Zone 1B & $\begin{array}{l}\text { Sewage } \\
\text { Treatment } \\
\text { Plant Rapid } \\
\text { Infiltration } \\
\text { Trenches }\end{array}$ & $\begin{array}{l}\text { Total dissolved solids, } \\
\text { chloride, nitrate }\end{array}$ & & & \\
\hline INTEC & & Zone 1B & CFA-17 & Inorganics and Organics & $\begin{array}{l}\text { Aluminum, Antimony, } \\
\text { Arsenic, Barium, } \\
\text { Cadmium, Calcium, } \\
\text { Chromium, Cobalt, } \\
\text { Copper, Iron, Lead, } \\
\text { Magnesium, } \\
\text { Manganese, Nickel, } \\
\text { Potassium, Sodium, } \\
\text { Vanadium, Zinc, } \\
\text { Benzo(a) anthracene, } \\
\text { Benzo(a)pyrene, } \\
\text { Benzo(b)fluoranthene, } \\
\text { Benzo(g,h,I)perylene }\end{array}$ & $\begin{array}{l}\text { Benzo(k)fluoranthene, } \\
\text { Butylbenzylphthalate, } \\
\text { Binaphthalene isomer, } \\
\text { Chrysene, 3,3- } \\
\text { Dichlorobenzidine, Di- } \\
\text { n-octylphthalate, } \\
\text { Dimethylphthalate, } \\
\text { Fluoranthene, } \\
\text { Indeno(1,2,3-cd) } \\
\text { pyrene, Naphthalene, } \\
\text { Phenanthrene, 2-Phenyl } \\
\text { naphthalene, Pyrene, } \\
\text { Terphenyl, }\end{array}$ & Aroclor-1260 \\
\hline INTEC & & Zone 1B & CFA-17 & Fire Station II Area A & Cleared & Cleared Ordnance Area & \\
\hline
\end{tabular}


Table B-5. (continued).

\begin{tabular}{|c|c|c|c|c|c|c|c|c|}
\hline \multirow[b]{2}{*}{ Facility } & \multirow[b]{2}{*}{ Well $^{\mathrm{a}}$} & \multirow[b]{2}{*}{ Zone } & \multirow[b]{2}{*}{ Sitecode } & \multicolumn{5}{|c|}{ Potential Contaminant } \\
\hline & & & & & GIS 1 & GIS 2 & & GIS 3 \\
\hline INTEC & & Zone 1B & CFA-17 & Roped Off Storage Area & Uncleared & Areas with Stained Soil & & \\
\hline INTEC & & Zone 1B & CFA-18 & Fuel Oil & NA & NA & NA & \\
\hline INTEC & & Zone 1B & CFA-18 & Fire Station II Area A & Cleared & Cleared Ordnance Area & & \\
\hline INTEC & & Zone 1B & CFA-18 & Roped Off Storage Area & Uncleared & Areas with Stained Soil & & \\
\hline INTEC & & Zone 1B & CFA-47 & Fire Station II & Cleared & Cleared Ordnance Area & & \\
\hline INTEC & & Zone 1B & CPP-13 & Metals and Rad & NA & NA & NA & \\
\hline INTEC & & Zone 1B & CPP-13 & Down Range Area & Uncleared & Down Range Area & & \\
\hline INTEC & & Zone 1B & CPP-14 & Metals, Organics, and Rad & NA & NA & NA & \\
\hline INTEC & & Zone 1B & CPP-14 & Down Range Area & Uncleared & Down Range Area & & \\
\hline INTEC & & Zone 1B & CPP-15 & Organics and Rad & $\begin{array}{l}\text { Kerosene, Tributyl } \\
\text { phosphate, Plutonium }\end{array}$ & NA & NA & \\
\hline INTEC & & Zone 1B & CPP-15 & Down Range Area & Uncleared & Down Range Area & & \\
\hline INTEC & & Zone 1B & СРP-16 & $\operatorname{Rad}$ & NA & NA & NA & \\
\hline INTEC & & Zone 1B & CPP-16 & Down Range Area & Uncleared & Down Range Area & & \\
\hline INTEC & & Zone 1B & CPP-18 & $\mathrm{Rad}$ & $\begin{array}{l}\text { Cesium-137, Strontium- } \\
90\end{array}$ & NA & NA & \\
\hline INTEC & & Zone 1B & CPP-18 & Down Range Area & Uncleared & Down Range Area & & \\
\hline INTEC & & Zone 1B & СРP-20 & Metals and Rad & NA & NA & NA & \\
\hline INTEC & & Zone 1B & CPP-20 & Down Range Area & Uncleared & Down Range Area & & \\
\hline INTEC & & Zone 1B & CPP-21 & Inorganics and Rad & $\begin{array}{l}\text { Cadmium, Mercury, } \\
\text { Nickel, Cesium-137, } \\
\text { Strontium-90 }\end{array}$ & NA & NA & \\
\hline INTEC & & Zone 1B & СРP-21 & Down Range Area & Uncleared & Down Range Area & & \\
\hline INTEC & & Zone 1B & СРP-23 & Metals and Rad & NA & NA & NA & \\
\hline INTEC & & Zone 1B & СРP-23 & & & Strontium-90 & & \\
\hline INTEC & & Zone 1B & СРP-23 & Down Range Area & Uncleared & Down Range Area & & \\
\hline
\end{tabular}


Table B-5. (continued).

\begin{tabular}{|c|c|c|c|c|c|c|c|c|}
\hline \multirow[b]{2}{*}{ Facility } & \multirow[b]{2}{*}{ Well $^{\mathrm{a}}$} & \multirow[b]{2}{*}{ Zone } & \multirow[b]{2}{*}{ Sitecode } & \multicolumn{5}{|c|}{ Potential Contaminant } \\
\hline & & & & & GIS 1 & GIS 2 & & GIS 3 \\
\hline INTEC & & Zone 1B & СРP-24 & Acids and Inorganics & $\begin{array}{l}\text { Mercuric nitrate, Nitric } \\
\text { acid, }\end{array}$ & NA & NA & \\
\hline INTEC & & Zone 1B & СРP-24 & Down Range Area & Uncleared & Down Range Area & & \\
\hline INTEC & & Zone 1B & CPP-25 & Metals and Organics & NA & NA & NA & \\
\hline INTEC & & Zone 1B & CPP-25 & Down Range Area & Uncleared & Down Range Area & & \\
\hline INTEC & & Zone $1 \mathrm{~B}$ & CPP-26 & Metals and Rad & NA & NA & NA & \\
\hline INTEC & & Zone $1 \mathrm{~B}$ & СРP-26 & Down Range Area & Uncleared & Down Range Area & & \\
\hline INTEC & & Zone 1B & CPP-27 & Organics and Rad & NA & NA & NA & \\
\hline INTEC & & Zone 1B & CPP-27 & Down Range Area & Uncleared & Down Range Area & & \\
\hline INTEC & & Zone 1B & CPP-28 & Metals, Organics, and Rad & NA & NA & NA & \\
\hline INTEC & & Zone 1B & CPP-28 & Down Range Area & Uncleared & Down Range Area & & \\
\hline INTEC & & Zone 1B & СРР-29 & Organics and Rad & NA & NA & NA & \\
\hline INTEC & & Zone $1 \mathrm{~B}$ & СРP-29 & Down Range Area & Uncleared & Down Range Area & & \\
\hline INTEC & & Zone $1 \mathrm{~B}$ & CPP-30 & Organics and Rad & NA & NA & NA & \\
\hline INTEC & & Zone 1B & CPP-30 & Down Range Area & Uncleared & Down Range Area & & \\
\hline INTEC & & Zone 1B & CPP-31 & Organics and Rad & NA & NA & NA & \\
\hline INTEC & & Zone 1B & CPP-31 & Down Range Area & Uncleared & Down Range Area & & \\
\hline INTEC & & Zone 1B & CPP-32 & Metals, Organics, and Rad & NA & NA & NA & \\
\hline INTEC & & Zone 1B & CPP-32 & Down Range Area & Uncleared & Down Range Area & & \\
\hline INTEC & & Zone $1 \mathrm{~B}$ & CPP-33 & Metals, Organics, and Rad & NA & NA & NA & \\
\hline INTEC & & Zone 1B & CPP-33 & Down Range Area & Uncleared & Down Range Area & & \\
\hline INTEC & & Zone 1B & СРP-34A & Inorganics and Rad & $\begin{array}{l}\text { Arsenic, Barium, } \\
\text { Chromium, Fluoride, } \\
\text { Lead, Selenium, Silver, } \\
\text { Cesium-137, Strontium- } \\
\text { 90, Uranium-238 }\end{array}$ & NA & NA & \\
\hline INTEC & & Zone 1B & CPP-34A & Down Range Area & Uncleared & Down Range Area & & \\
\hline
\end{tabular}


Table B-5. (continued).

\begin{tabular}{|c|c|c|c|c|c|c|c|}
\hline \multirow[b]{2}{*}{ Facility } & \multirow[b]{2}{*}{ Well $^{\mathrm{a}}$} & \multirow[b]{2}{*}{ Zone } & \multirow[b]{2}{*}{ Sitecode } & \multicolumn{4}{|c|}{ Potential Contaminant } \\
\hline & & & & & GIS 1 & GIS 2 & GIS 3 \\
\hline INTEC & & Zone 1B & CPP-34B & Inorganics and Rad & $\begin{array}{l}\text { Arsenic, Barium, } \\
\text { Chromium, Fluoride, } \\
\text { Lead, Selenium, Silver, } \\
\text { Cesium-137, Strontium- } \\
\text { 90, Uranium-238 }\end{array}$ & NA & NA \\
\hline INTEC & & Zone $1 \mathrm{~B}$ & CPP-34B & Down Range Area & Uncleared & Down Range Area & \\
\hline INTEC & & Zone 1B & CPP-35 & Inorganics and Rad & $\begin{array}{l}\text { Boron, Cadmium, } \\
\text { Chromium, Fluoride, } \\
\text { Lead, Mangances, } \\
\text { Mercury, Molybdenum, } \\
\text { Nickel, Nitrate, } \\
\text { Americium-241, } \\
\text { Cesium-137, Iodine- } \\
\text { 129, Neptunium-237, } \\
\text { Strontium-90, } \\
\text { Plutonium-238, } \\
\text { Plutonium-239, } \\
\text { Plutonium-240, } \\
\text { Technetium-99, Tritium, } \\
\text { Uranium-234, Uranium- } \\
235\end{array}$ & Uranium-238 & NA \\
\hline INTEC & & Zone $1 \mathrm{~B}$ & CPP-35 & Down Range Area & Uncleared & Down Range Area & \\
\hline INTEC & & Zone 1B & CPP-36 & $\begin{array}{l}\text { Inorganics, Organics, and } \\
\operatorname{Rad}\end{array}$ & $\begin{array}{l}\text { Boron, Cadmium, } \\
\text { Chromium, Fluoride, } \\
\text { Lead, Mangances, } \\
\text { Mercury, Molybdenum, } \\
\text { Nickel, Nitrate, Hexone, } \\
\text { Tributylphosphate, } \\
\text { 1,1,1-Trichloroethane, } \\
\text { 1,1,2-Trichloroethane, } \\
\text { Tetrachloroethylene, } \\
\text { Trichloroethylene }\end{array}$ & $\begin{array}{l}\text { Americium-241, } \\
\text { Cesium-137, Iodine- } \\
\text { 129, Neptunium-237, } \\
\text { Strontium-90, } \\
\text { Plutonium-238, } \\
\text { Plutonium-239, } \\
\text { Plutonium-240, } \\
\text { Technetium-99, Tritium, } \\
\text { Uranium-234, Uranium- } \\
\text { 235, Uranium-238 }\end{array}$ & NA \\
\hline INTEC & & Zone 1B & CPP-36 & Down Range Area & Uncleared & Down Range Area & \\
\hline
\end{tabular}


Table B-5. (continued).

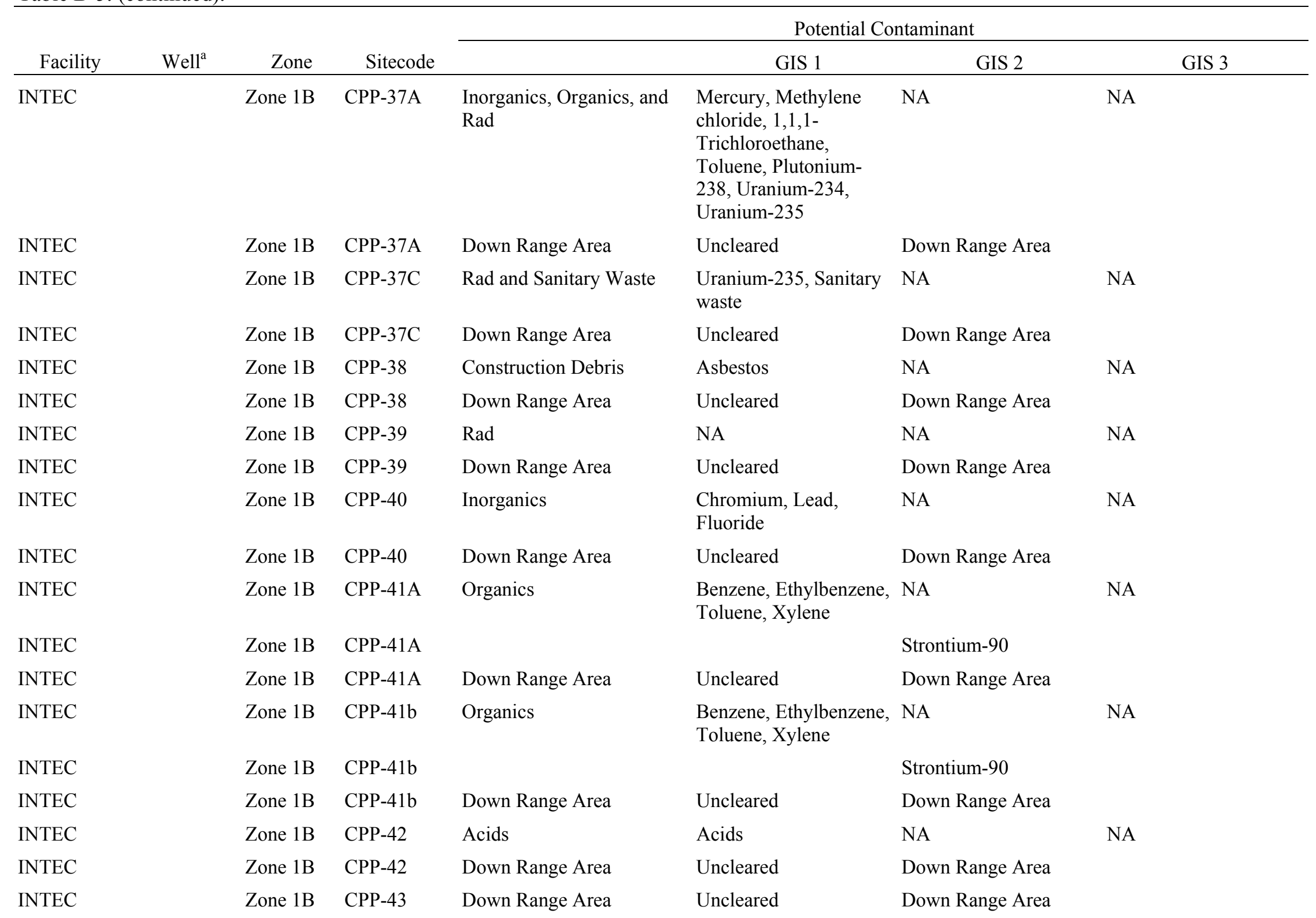


Table B-5. (continued).

\begin{tabular}{|c|c|c|c|c|c|c|c|}
\hline \multirow[b]{2}{*}{ Facility } & \multirow[b]{2}{*}{ Well $^{\mathrm{a}}$} & \multirow[b]{2}{*}{ Zone } & \multirow[b]{2}{*}{ Sitecode } & \multicolumn{4}{|c|}{ Potential Contaminant } \\
\hline & & & & & GIS 1 & GIS 2 & GIS 3 \\
\hline INTEC & & Zone 1B & СРP-44 & Metals & NA & NA & NA \\
\hline INTEC & & Zone 1B & СРP-44 & & & Strontium-90 & \\
\hline INTEC & & Zone 1B & СРP-44 & Down Range Area & Uncleared & Down Range Area & \\
\hline INTEC & & Zone 1B & CPP-45 & Acids and Inorganics & $\begin{array}{l}\text { Aluminum nitrate, } \\
\text { Hydrochloric acid, } \\
\text { Hydrofluoric acid, } \\
\text { Hyrdosulfuric acid, } \\
\text { Nitric acid }\end{array}$ & NA & NA \\
\hline INTEC & & Zone 1B & СРP-45 & & & Strontium-90 & \\
\hline INTEC & & Zone 1B & CPP-45 & Down Range Area & Uncleared & Down Range Area & \\
\hline INTEC & & Zone 1B & CPP-46 & Acids and Inorganics & $\begin{array}{l}\text { Fluorides, Hyrofluoric } \\
\text { acid, Zirconium }\end{array}$ & NA & NA \\
\hline INTEC & & Zone 1B & СРP-46 & Down Range Area & Uncleared & Down Range Area & \\
\hline INTEC & & Zone 1B & СРP-47 & Acids & Hydrofluoric acid & NA & NA \\
\hline INTEC & & Zone 1B & СРP-47 & Down Range Area & Uncleared & Down Range Area & \\
\hline INTEC & & Zone 1B & СРP-48 & $\operatorname{Rad}$ & NA & NA & NA \\
\hline INTEC & & Zone 1B & СРP-48 & & & Strontium-90 & \\
\hline INTEC & & Zone 1B & CPP-48 & Down Range Area & Uncleared & Down Range Area & \\
\hline INTEC & & Zone 1B & СРP-49 & PCBs & Aroclor-1260 (PCBs) & NA & NA \\
\hline INTEC & & Zone 1B & СРР-49 & Down Range Area & Uncleared & Down Range Area & \\
\hline INTEC & & Zone 1B & СРP-50 & PCBs & Aroclor-1260 (PCBs) & NA & NA \\
\hline INTEC & & Zone 1B & CPP-50 & Down Range Area & Uncleared & Down Range Area & \\
\hline INTEC & & Zone 1B & CPP-51 & PCBs & Aroclor-1260 (PCBs) & NA & NA \\
\hline INTEC & & Zone 1B & СРP-51 & & Iodine-129 & Strontium-90 & \\
\hline INTEC & & Zone 1B & CPP-51 & Down Range Area & Uncleared & Down Range Area & \\
\hline INTEC & & Zone 1B & CPP-52 & Acids & Mineral acids & NA & NA \\
\hline INTEC & & Zone 1B & СРP-52 & Down Range Area & Uncleared & Down Range Area & \\
\hline
\end{tabular}


Table B-5. (continued).

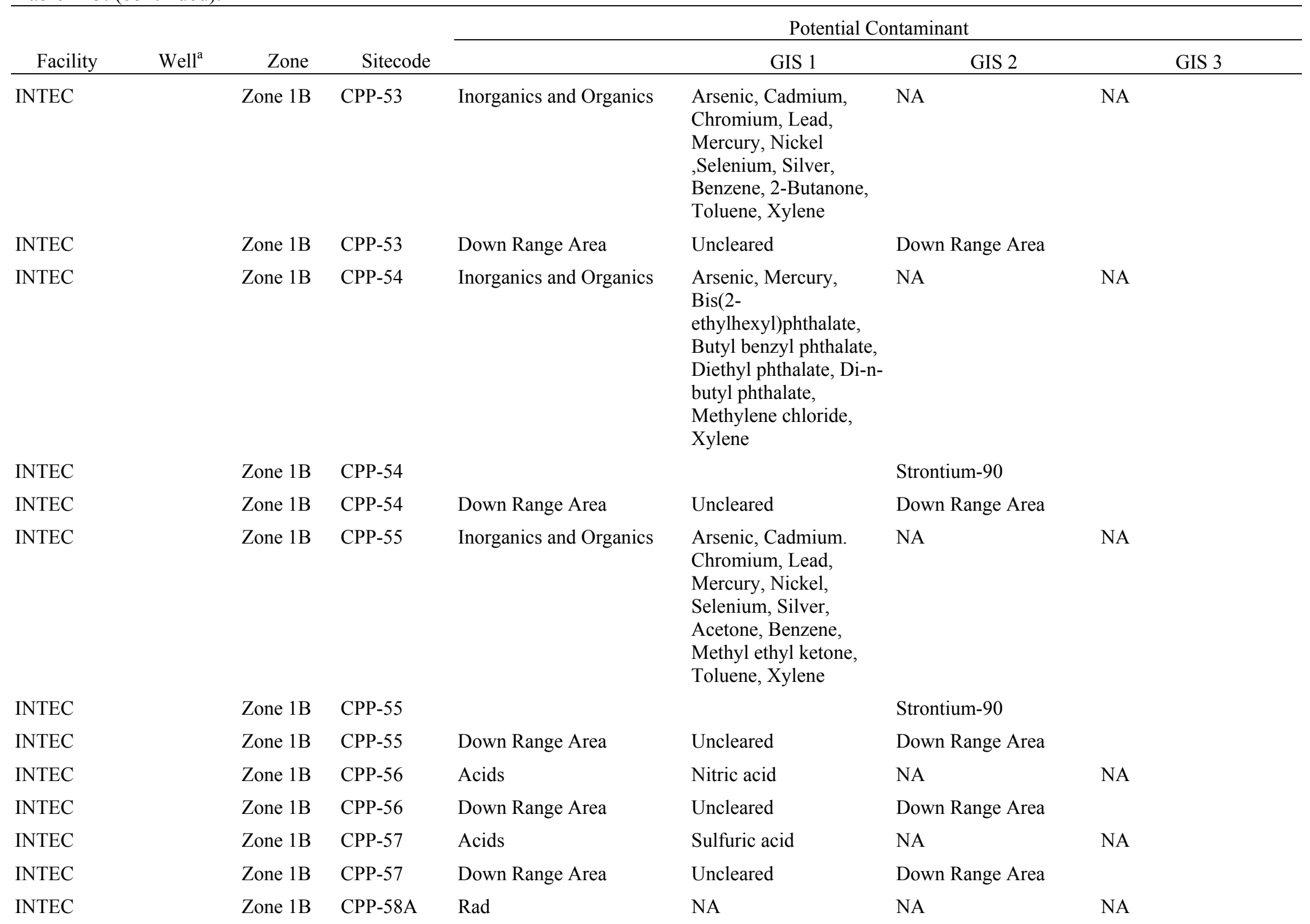


Table B-5. (continued).

\begin{tabular}{|c|c|c|c|c|c|c|c|c|}
\hline \multirow[b]{2}{*}{ Facility } & \multirow[b]{2}{*}{ Well $^{\mathrm{a}}$} & \multirow[b]{2}{*}{ Zone } & \multirow[b]{2}{*}{ Sitecode } & \multicolumn{5}{|c|}{ Potential Contaminant } \\
\hline & & & & & GIS 1 & GIS 2 & & GIS 3 \\
\hline INTEC & & Zone 1B & СРP-58A & Down Range Area & Uncleared & Down Range Area & & \\
\hline INTEC & & Zone 1B & СРP-58B & $\operatorname{Rad}$ & NA & NA & NA & \\
\hline INTEC & & Zone 1B & СРP-58B & Down Range Area & Uncleared & Down Range Area & & \\
\hline INTEC & & Zone 1B & СРP-59 & Organics & $\begin{array}{l}\text { Benzene, Ethylbenzene, } \\
\text { Toluene, Xylene }\end{array}$ & NA & NA & \\
\hline INTEC & & Zone 1B & СРP-59 & Down Range Area & Uncleared & Down Range Area & & \\
\hline INTEC & & Zone 1B & СРP-60 & Inorganics and Organics & $\begin{array}{l}\text { Arsenic, Cadmium, } \\
\text { Chromium, Lead, } \\
\text { Mercury, Nickel, } \\
\text { Selenium, Silver, } \\
\text { Acetone, Benzene, } \\
\text { Methyl ethyl ketone, } \\
\text { Toluene, Xylene }\end{array}$ & NA & NA & \\
\hline INTEC & & Zone 1B & СРP-60 & Down Range Area & Uncleared & Down Range Area & & \\
\hline INTEC & & Zone 1B & CPP-61 & PCBs & Aroclor-1260 (PCBs) & NA & NA & \\
\hline INTEC & & Zone 1B & СРP-61 & & & Strontium-90 & & \\
\hline INTEC & & Zone 1B & СРP-61 & Down Range Area & Uncleared & Down Range Area & & \\
\hline INTEC & & Zone 1B & СРP-62 & Inorganics and Organics & $\begin{array}{l}\text { Mercury, Organic } \\
\text { solvents }\end{array}$ & NA & NA & \\
\hline INTEC & & Zone 1B & СРP-62 & Down Range Area & Uncleared & Down Range Area & & \\
\hline INTEC & & Zone 1B & СРP-63 & Organics & Hexone & NA & NA & \\
\hline INTEC & & Zone 1B & СРP-63 & Down Range Area & Uncleared & Down Range Area & & \\
\hline INTEC & & Zone 1B & СРP-64 & Inorganics and Organics & Lead, Mercury, Hexone & NA & NA & \\
\hline INTEC & & Zone 1B & CPP-64 & & & Strontium-90 & & \\
\hline INTEC & & Zone 1B & CPP-64 & Down Range Area & Uncleared & Down Range Area & & \\
\hline
\end{tabular}


Table B-5. (continued).

\begin{tabular}{|c|c|c|c|c|c|c|c|}
\hline \multirow[b]{2}{*}{ Facility } & \multirow[b]{2}{*}{ Well $^{\mathrm{a}}$} & \multirow[b]{2}{*}{ Zone } & \multirow[b]{2}{*}{ Sitecode } & \multicolumn{4}{|c|}{ Potential Contaminant } \\
\hline & & & & & GIS 1 & GIS 2 & GIS 3 \\
\hline INTEC & & Zone 1B & СРP-65 & Inorganics and $\mathrm{Rad}$ & $\begin{array}{l}\text { Arsenic, Barium, } \\
\text { Cadmium, Chromium, } \\
\text { Copper, Lead, Mercury, } \\
\text { Molybdenum, Nickel, } \\
\text { Selenium, Silver, Zinc, } \\
\text { Plutonium-239/240, } \\
\text { Strontium-90, Sanitary } \\
\text { waste }\end{array}$ & NA & NA \\
\hline INTEC & & Zone 1B & СРP-65 & Down Range Area & Uncleared & Down Range Area & \\
\hline INTEC & & Zone 1B & СРP-66 & $\begin{array}{l}\text { Inorganics, Organics, and } \\
\operatorname{Rad}\end{array}$ & $\begin{array}{l}\text { Antimony, Arsenic, } \\
\text { Barium, Beryllium, } \\
\text { Boron, Cadmium, } \\
\text { Chromium, Cobalt, } \\
\text { Copper, Fluoride, Lead, } \\
\text { Manganese, Mercury, } \\
\text { Molybdenum, Nickel, } \\
\text { Selenium, Silver, } \\
\text { Strontium, Tin, } \\
\text { Vanadium, Zinc, } \\
\text { Potassium-40, Thorium- } \\
\text { 232, Uranium-235, } \\
\text { Uranium-238 }\end{array}$ & NA & NA \\
\hline INTEC & & Zone 1B & СРP-66 & & & Strontium-90 & \\
\hline INTEC & & Zone 1B & СРP-66 & & Iodine-129 & Strontium-90 & \\
\hline INTEC & & Zone 1B & СРP-66 & Down Range Area & Uncleared & Down Range Area & \\
\hline INTEC & & Zone 1B & СРP-68 & Down Range Area & Uncleared & Down Range Area & \\
\hline INTEC & & Zone 1B & СРP-70 & & & Strontium-90 & \\
\hline INTEC & & Zone 1B & СРP-70 & Down Range Area & Uncleared & Down Range Area & \\
\hline INTEC & & Zone 1B & CPP-71 & & & Strontium-90 & \\
\hline INTEC & & Zone 1B & CPP-71 & Down Range Area & Uncleared & Down Range Area & \\
\hline INTEC & & Zone 1B & CPP-72 & Down Range Area & Uncleared & Down Range Area & \\
\hline
\end{tabular}


Table B-5. (continued).

\begin{tabular}{|c|c|c|c|c|c|c|c|c|}
\hline \multirow[b]{2}{*}{ Facility } & \multirow{2}{*}{ Well $^{\mathrm{a}}$} & \multirow[b]{2}{*}{ Zone } & \multirow[b]{2}{*}{ Sitecode } & \multicolumn{5}{|c|}{ Potential Contaminant } \\
\hline & & & & & GIS 1 & GIS 2 & & GIS 3 \\
\hline INTEC & & Zone 1B & СРP-73 & & & Strontium-90 & & \\
\hline INTEC & & Zone 1B & СРP-73 & Down Range Area & Uncleared & Down Range Area & & \\
\hline INTEC & & Zone 1B & CPP-76 & Down Range Area & Uncleared & Down Range Area & & \\
\hline INTEC & & Zone 1B & СРP-77 & Down Range Area & Uncleared & Down Range Area & & \\
\hline INTEC & & Zone 1B & СРP-78 & $\operatorname{Rad}$ & NA & NA & NA & \\
\hline INTEC & & Zone 1B & СРР-78 & & Iodine-129 & Strontium-90 & & \\
\hline INTEC & & Zone 1B & СРР-78 & Down Range Area & Uncleared & Down Range Area & & \\
\hline INTEC & & Zone 1B & СРР-79 & Organics and Rad & NA & NA & NA & \\
\hline INTEC & & Zone 1B & СРР-79 & Down Range Area & Uncleared & Down Range Area & & \\
\hline INTEC & & Zone 1B & СРP-81 & Metals & NA & NA & NA & \\
\hline INTEC & & Zone 1B & СРP-81 & Down Range Area & Uncleared & Down Range Area & & \\
\hline INTEC & & Zone 1B & СРP-82 & No Action & NA & NA & NA & \\
\hline INTEC & & Zone 1B & СРP-82 & & & Strontium-90 & & \\
\hline INTEC & & Zone 1B & СРP-82 & Down Range Area & Uncleared & Down Range Area & & \\
\hline INTEC & & Zone 1B & СРP-84 & PCBs & NA & NA & NA & \\
\hline INTEC & & Zone 1B & СРP-84 & Down Range Area & Uncleared & Down Range Area & & \\
\hline INTEC & & Zone 1B & CPP-85 & $\operatorname{Rad}$ & NA & NA & NA & \\
\hline INTEC & & Zone 1B & CPP-85 & & & Strontium-90 & & \\
\hline INTEC & & Zone 1B & СРP-85 & Down Range Area & Uncleared & Down Range Area & & \\
\hline INTEC & & Zone 1B & СРP-87 & $\operatorname{Rad}$ & NA & NA & NA & \\
\hline INTEC & & Zone 1B & СРP-87 & Down Range Area & Uncleared & Down Range Area & & \\
\hline INTEC & & Zone 1B & СРP-88 & & & Strontium-90 & & \\
\hline INTEC & & Zone 1B & СРP-88 & & Iodine-129 & Strontium-90 & & \\
\hline INTEC & & Zone 1B & СРP-88 & Down Range Area & Uncleared & Down Range Area & & \\
\hline INTEC & & Zone 1B & СРР-94 & Acids & Hydrofluoric acid & NA & NA & \\
\hline INTEC & & Zone 1B & СРP-94 & Down Range Area & Uncleared & Down Range Area & & \\
\hline
\end{tabular}


Table B-5. (continued).

\begin{tabular}{|c|c|c|c|c|c|c|c|}
\hline \multirow[b]{2}{*}{ Facility } & \multirow[b]{2}{*}{$\mathrm{Well}^{\mathrm{a}}$} & \multirow[b]{2}{*}{ Zone } & \multirow[b]{2}{*}{ Sitecode } & \multicolumn{4}{|c|}{ Potential Contaminant } \\
\hline & & & & & GIS 1 & GIS 2 & GIS 3 \\
\hline INTEC & & Zone 1B & CPP-95 & $\operatorname{Rad}$ & $\begin{array}{l}\text { Americium-241, } \\
\text { Cesium-134, Cesium- } \\
\text { 137, Potassium-40, } \\
\text { Plutonium-238, } \\
\text { Plutonium-239/240, } \\
\text { Strontium-90, Uranium- } \\
\text { 233, Uranium-234, } \\
\text { Uranium-235 }\end{array}$ & NA & NA \\
\hline INTEC & & Zone 1B & CPP-95 & & & Strontium-90 & \\
\hline INTEC & & Zone 1B & CPP-95 & & Iodine-129 & Strontium-90 & \\
\hline INTEC & & Zone $1 \mathrm{~B}$ & CPP-95 & Down Range Area & Uncleared & Down Range Area & \\
\hline INTEC & & Zone 1B & CPP-95 & $\begin{array}{l}\text { Zone East Of The Big Lost } \\
\text { River }\end{array}$ & Uncleared & Down Range Area & \\
\hline INTEC & & Zone 1B & CPP-95 & $\begin{array}{l}\text { Explosive Storage Bunkers } \\
\text { North Of Intec }\end{array}$ & Cleared & Cleared Ordnance Area & \\
\hline INTEC & & Zone 1B & CPP-95 & Down Range Area & Uncleared & Down Range Area & \\
\hline INTEC & & Zone $1 \mathrm{~B}$ & DF-1 & Construction Debris & $\begin{array}{l}\text { Manure, Straw, Hay, Oil } \\
\text { and Gas cans, Glass } \\
\text { bottles, Wire, Wood, } \\
\text { Metal, used } \\
\text { Pharmaceutical bottles }\end{array}$ & NA & NA \\
\hline INTEC & & Zone 1B & DF-1 & Down Range Area & Uncleared & Down Range Area & \\
\hline INTEC & & Zone $1 \mathrm{~B}$ & DF-1 & Experimental Field Station & Cleared & Cleared Ordnance Area & \\
\hline INTEC & & Zone 1B & & Down Range Area & Uncleared & Down Range Area & \\
\hline INTEC & & Zone 1B & & $\begin{array}{l}\text { Land Mine And Fuze Burn } \\
\text { Area }\end{array}$ & Surface Cleared & Cleared Ordnance Area & \\
\hline INTEC & & Zone 1B & & Land Mine Fuze Burn Area & Uncleared & Identified UXO Area & \\
\hline INTEC & & Zone 1B & & Fuze Burn Area 5 & Failed QC & $\begin{array}{l}\text { UXO Area that Failed } \\
\text { Quality Control } \\
\text { Inspection }\end{array}$ & \\
\hline
\end{tabular}


Table B-5. (continued).

\begin{tabular}{|c|c|c|c|c|c|c|c|}
\hline \multirow[b]{2}{*}{ Facility } & \multirow[b]{2}{*}{ Well $^{\mathrm{a}}$} & \multirow[b]{2}{*}{ Zone } & \multirow[b]{2}{*}{ Sitecode } & \multicolumn{4}{|c|}{ Potential Contaminant } \\
\hline & & & & & GIS 1 & GIS 2 & GIS 3 \\
\hline INTEC & & Zone 1B & & Experimental Field Station & Uncleared & Areas with Stained Soil & \\
\hline INTEC & & Zone 1B & & Fuze Burn Area 1 & Cleared & Cleared Ordnance Area & \\
\hline INTEC & & Zone 1B & & Fuze Burn Area 4 & Failed QC & $\begin{array}{l}\text { UXO Area that Failed } \\
\text { Quality Control } \\
\text { Inspection }\end{array}$ & \\
\hline INTEC & & Zone 1B & & Land Mine Fuze Burn Area & Uncleared & Identified UXO Area & \\
\hline INTEC & & Zone 1B & & Fire Station II Area A & Cleared & Cleared Ordnance Area & \\
\hline INTEC & & Zone 1B & & Fire Station II & Uncleared & Areas with Stained Soil & \\
\hline INTEC & & Zone 1B & & $\begin{array}{l}\text { NPR Site, Ordnance } \\
\text { Location }\end{array}$ & Assessed & Identified UXO Area & \\
\hline INTEC & & Zone 1B & & Roped Off Storage Area & Uncleared & Areas with Stained Soil & \\
\hline INTEC & & Zone 1B & & Fire Station II Area B & Cleared & Cleared Ordnance Area & \\
\hline INTEC & & Zone 1B & & Fire Station II/NOAA & Assessed & Identified UXO Area & \\
\hline INTEC & & Zone 1B & & Fire Station II & Uncleared & Areas with Stained Soil & \\
\hline INTEC & & Zone 1B & & NOAA Area A & Cleared & Cleared Ordnance Area & \\
\hline INTEC & & Zone 1B & & NOAA & Uncleared & & \\
\hline INTEC & & Zone 1B & & Unknown & Cleared & Cleared Ordnance Area & \\
\hline INTEC & & Zone 1B & & NOAA Area B & Cleared & Cleared Ordnance Area & \\
\hline INTEC & & Zone 1B & & NOAA Area $\mathrm{C}$ & Cleared & Cleared Ordnance Area & \\
\hline INTEC & & Zone 1B & & Burn Ring South Of EFS & Uncleared & & \\
\hline INTEC & & Zone 1B & & NOAA & Cleared & Cleared Ordnance Area & \\
\hline INTEC & & Zone 1B & & NOAA Area D & Cleared & Cleared Ordnance Area & \\
\hline INTEC & & Zone 2 & & Mass Detonation Area & Uncleared & & \\
\hline INTEC & & Zone 2 & & Mass Detonation Area & Assessed & Identified UXO Area & \\
\hline INTEC & & Zone 2 & & Anaconda Power Line & Cleared & Cleared Ordnance Area & \\
\hline INTEC & & Zone 2 & & Down Range Area & Uncleared & Down Range Area & \\
\hline
\end{tabular}


Table B-5. (continued).

\begin{tabular}{|c|c|c|c|c|c|c|c|}
\hline \multirow[b]{2}{*}{ Facility } & \multirow[b]{2}{*}{ Well $^{\mathrm{a}}$} & \multirow[b]{2}{*}{ Zone } & \multirow[b]{2}{*}{ Sitecode } & \multicolumn{4}{|c|}{ Potential Contaminant } \\
\hline & & & & & GIS 1 & GIS 2 & GIS 3 \\
\hline INTEC & & Zone 2 & & Two Craters Area & Assessed & & \\
\hline INTEC & & Zone 2 & & $\begin{array}{l}\text { Zone East Of The Big Lost } \\
\text { River }\end{array}$ & Uncleared & Down Range Area & \\
\hline INTEC & & Zone 2 & & Unknown & Uncleared & & \\
\hline INTEC & & Zone 2 & & Unknown & Uncleared & & \\
\hline INTEC & & Zone 2 & & Unknown & Uncleared & & \\
\hline INTEC & & Zone 2 & & $\begin{array}{l}\text { Dirt Mounds Near Dairy } \\
\text { Farm, NOAA, NRF }\end{array}$ & Close Area & & \\
\hline INTEC & & Zone 2 & & Unknown & Cleared & Cleared Ordnance Area & \\
\hline INTEC & & Zone 2 & & $\begin{array}{l}\text { Dirt Mounds Near Dairy } \\
\text { Farm, NOAA, NRF }\end{array}$ & CLOSE AREA & & \\
\hline INTEC & & Zone 2 & & Unknown & Cleared & Cleared Ordnance Area & \\
\hline INTEC & & Zone 2 & & $\begin{array}{l}\text { Dirt Mounds Near Dairy } \\
\text { Farm, NOAA, NRF }\end{array}$ & CLOSE AREA & & \\
\hline INTEC & & Zone 3 & ARVFS-01 & Down Range Area & Uncleared & Down Range Area & \\
\hline INTEC & & Zone 3 & ARVFS-02 & Down Range Area & Uncleared & Down Range Area & \\
\hline INTEC & & Zone 3 & NRF-01 & Down Range Area & Uncleared & Down Range Area & \\
\hline INTEC & & Zone 3 & NRF-02 & Down Range Area & Uncleared & Down Range Area & \\
\hline INTEC & & Zone 3 & NRF-11 & Down Range Area & Uncleared & Down Range Area & \\
\hline INTEC & & Zone 3 & NRF-12A & Down Range Area & Uncleared & Down Range Area & \\
\hline INTEC & & Zone 3 & NRF-12B & Down Range Area & Uncleared & Down Range Area & \\
\hline INTEC & & Zone 3 & NRF-14 & Inorganics and Rad & $\begin{array}{l}\text { Arsenic, Barium, } \\
\text { Cadmium, Chromium, } \\
\text { Lead, Cesium-137, } \\
\text { Cobalt-60, Strontium-90 }\end{array}$ & NA & NA \\
\hline INTEC & & Zone 3 & NRF-14 & Down Range Area & Uncleared & Down Range Area & \\
\hline INTEC & & Zone 3 & NRF-16 & Down Range Area & Uncleared & Down Range Area & \\
\hline INTEC & & Zone 3 & NRF-18A & Down Range Area & Uncleared & Down Range Area & \\
\hline
\end{tabular}


Table B-5. (continued).

\begin{tabular}{|c|c|c|c|c|c|c|c|}
\hline \multirow[b]{2}{*}{ Facility } & \multirow[b]{2}{*}{ Well $^{\mathrm{a}}$} & \multirow[b]{2}{*}{ Zone } & \multirow[b]{2}{*}{ Sitecode } & \multicolumn{4}{|c|}{ Potential Contaminant } \\
\hline & & & & & GIS 1 & GIS 2 & GIS 3 \\
\hline INTEC & & Zone 3 & NRF-19 & Inorganics and Rad & $\begin{array}{l}\text { Aluminum, Antimony, } \\
\text { Arsenic, Barium, } \\
\text { Beryllium, Cadmium, } \\
\text { Chromium, Copper, } \\
\text { Iron, Lead, Manganese, } \\
\text { Mercury, Nickel, } \\
\text { Selenium, Silver, } \\
\text { Sodium, Thallium, Zinc, } \\
\text { Cesium-137, Cobalt-60, } \\
\text { Strontium-90 }\end{array}$ & NA & NA \\
\hline INTEC & & Zone 3 & NRF-19 & Down Range Area & Uncleared & Down Range Area & \\
\hline INTEC & & Zone 3 & NRF-21A & Down Range Area & Uncleared & Down Range Area & \\
\hline INTEC & & Zone 3 & NRF-21B & Down Range Area & Uncleared & Down Range Area & \\
\hline INTEC & & Zone 3 & NRF-23 & Down Range Area & Uncleared & Down Range Area & \\
\hline INTEC & & Zone 3 & NRF-42 & Down Range Area & Uncleared & Down Range Area & \\
\hline INTEC & & Zone 3 & NRF-43 & Down Range Area & Uncleared & Down Range Area & \\
\hline INTEC & & Zone 3 & NRF-51 & Down Range Area & Uncleared & Down Range Area & \\
\hline INTEC & & Zone 3 & NRF-53 & Down Range Area & Uncleared & Down Range Area & \\
\hline INTEC & & Zone 3 & NRF-66 & Down Range Area & Uncleared & Down Range Area & \\
\hline INTEC & & Zone 3 & NRF-80 & Down Range Area & Uncleared & Down Range Area & \\
\hline INTEC & & Zone 3 & NRF-81 & Down Range Area & Uncleared & Down Range Area & \\
\hline INTEC & & Zone 3 & & Down Range Area & Uncleared & Down Range Area & \\
\hline INTEC & & Zone 3 & & Railcar Explosion Area & Uncleared & & \\
\hline INTEC & & Zone 3 & & Anaconda Power Line & Cleared & Cleared Ordnance Area & \\
\hline INTEC & & Zone 3 & & Down Range Area & Uncleared & Down Range Area & \\
\hline INTEC & & Zone 3 & & Mass Detonation Area & Uncleared & & \\
\hline INTEC & & Zone 3 & & Mass Detonation Area & Assessed & Identified UXO Area & \\
\hline INTEC & & Zone 3 & & $\begin{array}{l}\text { Zone East Of The Big Lost } \\
\text { River }\end{array}$ & Uncleared & Down Range Area & \\
\hline
\end{tabular}


Table B-5. (continued).

\begin{tabular}{|c|c|c|c|c|c|c|c|}
\hline \multirow[b]{2}{*}{ Facility } & \multirow[b]{2}{*}{ Well $^{\mathrm{a}}$} & \multirow[b]{2}{*}{ Zone } & \multirow[b]{2}{*}{ Sitecode } & \multicolumn{4}{|c|}{ Potential Contaminant } \\
\hline & & & & & GIS 1 & GIS 2 & GIS 3 \\
\hline INTEC & & Zone 3 & & Mass Detonation Area & Cleared & Cleared Ordnan & \\
\hline
\end{tabular}


Table B-6. Main Gate.

\begin{tabular}{|c|c|c|c|c|c|c|c|c|}
\hline \multirow[b]{2}{*}{ Facility } & \multirow[b]{2}{*}{ Well $^{\mathrm{a}}$} & \multirow[b]{2}{*}{ Zone } & \multirow[b]{2}{*}{ Sitecode } & \multicolumn{5}{|c|}{ Potential Contaminant } \\
\hline & & & & & GIS 1 & GIS 2 & & GIS 3 \\
\hline Main Gate & & Zone $1 \mathrm{~A}$ & & Down Range ${ }^{\mathrm{b}}$ Area & Uncleared & Down Range Area & & \\
\hline Main Gate & & Zone 1B & & Down Range Area & Uncleared & Down Range Area & & \\
\hline Main Gate & & Zone 2 & EOCR-01 & Down Range Area & Uncleared & Down Range Area & & \\
\hline Main Gate & & Zone 2 & EOCR-02 & Down Range Area & Uncleared & Down Range Area & & \\
\hline Main Gate & & Zone 2 & EOCR-03 & Down Range Area & Uncleared & Down Range Area & & \\
\hline Main Gate & & Zone 2 & EOCR-04 & Down Range Area & Uncleared & Down Range Area & & \\
\hline Main Gate & & Zone 2 & EOCR-05 & Down Range Area & Uncleared & Down Range Area & & \\
\hline Main Gate & & Zone 2 & OMRE-01 & Down Range Area & Uncleared & Down Range Area & & \\
\hline Main Gate & & Zone 2 & OMRE-01 & Organics and Rad & NA & NA & NA & \\
\hline Main Gate & & Zone 2 & STF-01 & Construction Debris & Asbestos & NA & NA & \\
\hline Main Gate & & Zone 2 & STF-01 & Down Range Area & Uncleared & Down Range Area & & \\
\hline Main Gate & & Zone 2 & STF-02 & Down Range Area & Uncleared & Down Range Area & & \\
\hline Main Gate & & Zone 2 & STF-02 & Inorganics & Brass, Copper, Lead & NA & NA & \\
\hline Main Gate & & Zone 2 & & Down Range Area & Uncleared & Down Range Area & & \\
\hline Main Gate & & Zone 3 & & Down Range Area & Uncleared & Down Range Area & & \\
\hline Main Gate & & Zone 3 & & Rye Grass Flats & Assessed & Identified UXO Area & & \\
\hline
\end{tabular}


Table B-7. Naval Reactors Facility.

\begin{tabular}{|c|c|c|c|c|}
\hline Facility & Well $^{\mathrm{a}}$ & Zone & Sitecode & Potential Contaminant \\
\hline $\mathrm{NRF}$ & & Zone $1 \mathrm{~A}$ & & Down Range ${ }^{\mathrm{b}}$ Area \\
\hline NRF & & Zone $1 \mathrm{~B}$ & $\begin{array}{l}\text { NRF Industrial Waste Ditch } \\
\text { (26) }\end{array}$ & Calcium, chloride, potassium, sodium, and sulfate, aluminum, iron, manganese \\
\hline NRF & & Zone 1B & NRF sewage lagoons (23) & Calcium, chloride, potassium, sodium, and sulfate, aluminum, iron, magnesium, nitrate, and TOC \\
\hline NRF & & Zone 1B & NRF-01 & Down Range Area \\
\hline $\mathrm{NRF}$ & & Zone $1 \mathrm{~B}$ & NRF-17 & Down Range Area \\
\hline NRF & & Zone 1B & NRF-80 & Down Range Area \\
\hline
\end{tabular}

a. The well column is blank if the information applies to all wells. The well number is specified if information is specific to that well.

b. Downrange means out of capture zone. 
Table B-8. Power Burst Facility.

\begin{tabular}{|c|c|c|c|c|c|c|c|c|}
\hline \multirow[b]{2}{*}{ Facility } & \multirow[b]{2}{*}{ Well $^{\mathrm{a}}$} & \multirow[b]{2}{*}{ Zone } & \multirow[b]{2}{*}{ Sitecode } & \multicolumn{5}{|c|}{ Potential Contaminant } \\
\hline & & & & & GIS 1 & GIS 2 & & GIS 3 \\
\hline PBF & & Zone $1 \mathrm{~A}$ & & Down Range Area ${ }^{b}$ & Uncleared & Down Range Area & & \\
\hline PBF & & Zone 1B & PBF-01 & Down Range Area & Uncleared & Down Range Area & & \\
\hline PBF & & Zone 1B & PBF-02 & Down Range Area & Uncleared & Down Range Area & & \\
\hline PBF & & Zone 1B & PBF-03 & Down Range Area & Uncleared & Down Range Area & & \\
\hline PBF & & Zone 1B & PBF-32 & Down Range Area & Uncleared & Down Range Area & & \\
\hline PBF & & Zone 1B & PBF-32 & Fuel Oil and Rad. & NA & NA & NA & \\
\hline PBF & & Zone 1B & PBF-35 & Down Range Area & Uncleared & Down Range Area & & \\
\hline PBF & & Zone $1 \mathrm{~B}$ & PBF-35 & PCBs & & & & \\
\hline PBF & & Zone $1 \mathrm{~B}$ & & Down Range Area & Uncleared & Down Range Area & & \\
\hline PBF & & Zone 2 & PBF-16 & $\begin{array}{l}\text { Acids, Bases, and } \\
\text { Inorganics }\end{array}$ & $\begin{array}{l}\text { Arsenic, Cadmium, Chromium, } \\
\text { Lead, Mercury, Sulfuric acid, } \\
\text { Sodium hydroxide }\end{array}$ & NA & NA & \\
\hline PBF & & Zone 2 & PBF-16 & Down Range Area & Uncleared & Down Range Area & & \\
\hline PBF & & Zone 2 & PBF-35 & Down Range Area & Uncleared & Down Range Area & & \\
\hline PBF & & Zone 2 & PBF-35 & $\mathrm{PCBs}$ & & & & \\
\hline PBF & & Zone 2 & & Down Range Area & Uncleared & Down Range Area & & \\
\hline PBF & & Zone 3 & PBF-10 & $\begin{array}{l}\text { Acids, Bases, and } \\
\text { Inorganics }\end{array}$ & $\begin{array}{l}\text { Chromium, Sulfuric acid, } \\
\text { Sodium hydroxide }\end{array}$ & NA & NA & \\
\hline PBF & & Zone 3 & PBF-10 & Down Range Area & Uncleared & Down Range Area & & \\
\hline PBF & & Zone 3 & PBF-13 & Construction, Inorganics & $\begin{array}{l}\text { Lumber, Empty containers, Soil, } \\
\text { Basalt, Piping, Asbestos, Cans, } \\
\text { Barrels, Metal. Metal cable, } \\
\text { Fencing, Concrete, Insulation - } \\
\text { Cadmium, Chromium, Lead, } \\
\text { Nickel, Zinc, Asbestos, } \\
\text { Methylene chloride, Toluene }\end{array}$ & NA & NA & \\
\hline PBF & & Zone 3 & PBF-13 & Down Range Area & Uncleared & Down Range Area & & \\
\hline PBF & & Zone 3 & PBF-14 & Down Range Area & Uncleared & Down Range Area & & \\
\hline
\end{tabular}


Table B-8. (continued).

\begin{tabular}{|c|c|c|c|c|c|c|c|}
\hline \multirow[b]{2}{*}{ Facility } & \multirow[b]{2}{*}{ Well $^{\mathrm{a}}$} & \multirow[b]{2}{*}{ Zone } & \multirow[b]{2}{*}{ Sitecode } & \multicolumn{4}{|c|}{ Potential Contaminant } \\
\hline & & & & & GIS 1 & GIS 2 & GIS 3 \\
\hline PBF & & Zone 3 & PBF-14 & Fuel Oil and Rad. & NA & NA & NA \\
\hline PBF & & Zone 3 & PBF-16 & $\begin{array}{l}\text { Acids, Bases, and } \\
\text { Inorganics }\end{array}$ & $\begin{array}{l}\text { Arsenic, Cadmium, Chromium, } \\
\text { Lead, Mercury, Sulfuric acid, } \\
\text { Sodium hydroxide }\end{array}$ & NA & NA \\
\hline PBF & & Zone 3 & PBF-16 & Down Range Area & Uncleared & Down Range Area & \\
\hline PBF & & Zone 3 & PBF-17 & Down Range Area & Uncleared & Down Range Area & \\
\hline PBF & & Zone 3 & PBF-31 & Down Range Area & Uncleared & Down Range Area & \\
\hline PBF & & Zone 3 & PBF-31 & Fuel Oil and Rad. & NA & NA & NA \\
\hline PBF & & Zone 3 & PBF-35 & Down Range Area & Uncleared & Down Range Area & \\
\hline PBF & & Zone 3 & PBF-35 & PCBs & & & \\
\hline PBF & & Zone 3 & & Down Range Area & Uncleared & Down Range Area & \\
\hline
\end{tabular}

a. The well column is blank if the information applies to all wells. The well number is specified if information is specific to that well. 
Table B-9. Radioactive Waste Management Complex.

\begin{tabular}{|c|c|c|c|c|c|c|}
\hline Facility & Well $^{\mathrm{a}}$ & Zone & Sitecode & Potential & Contaminant & \\
\hline RWMC & & Zone $1 \mathrm{~A}$ & & Arco High Altitude Bombing Range & Uncleared & Practice Bombing Range \\
\hline RWMC & & Zone 1B & Subsurface Disposal Area & Arco High Altitude Bombing Range & Uncleared & Practice Bombing Range \\
\hline RWMC & & Zone 1B & Subsurface Disposal Area & $\begin{array}{l}\text { Radionuclides, volatile organic compounds, } \\
\text { nitrate, metals (chromium) }\end{array}$ & & \\
\hline RWMC & & Zone 1B & & Arco High Altitude Bombing Range & Uncleared & Practice Bombing Range \\
\hline RWMC & & Zone 2 & Subsurface Disposal Area & Arco High Altitude Bombing Range & Uncleared & Practice Bombing Range \\
\hline RWMC & & Zone 2 & Subsurface Disposal Area & $\begin{array}{l}\text { Radionuclides, volatile organic compounds, } \\
\text { nitrate, metals (chromium) }\end{array}$ & & \\
\hline RWMC & & Zone 2 & & Arco High Altitude Bombing Range & Uncleared & Practice Bombing Range \\
\hline RWMC & & Zone 3 & Subsurface Disposal Area & Arco High Altitude Bombing Range & Uncleared & Practice Bombing Range \\
\hline RWMC & & Zone 3 & Subsurface Disposal Area & $\begin{array}{l}\text { Radionuclides, volatile organic compounds, } \\
\text { nitrate, metals (chromium) }\end{array}$ & & \\
\hline RWMC & & Zone 3 & & Arco High Altitude Bombing Range & Uncleared & Practice Bombing Range \\
\hline
\end{tabular}


Table B-10. Test Area North/Contained Test Facility.

\begin{tabular}{ccrlll}
\hline Facility & Well $^{\mathrm{a}}$ & Zone & Sitecode & & Potential Contaminant \\
\hline TAN/CTF & Zone 1A & LOFT-04 & Down Range Area $^{\mathrm{b}}$ & Uncleared & Down Range Area \\
TAN/CTF & Zone 1A & & Down Range Area & Uncleared & Down Range Area \\
TAN/CTF & Zone 1B & & Down Range Area & Uncleared & Down Range Area \\
TAN/CTF & Zone 2 & & Down Range Area & Uncleared & Down Range Area \\
TAN/CTF & Zone 3 & LOFT-13 & Down Range Area & Uncleared & Down Range Area \\
TAN/CTF & Zone 3 & & Down Range Area & Uncleared & Down Range Area \\
\hline
\end{tabular}

a. The well column is blank if the information applies to all wells. The well number is specified if information is specific to that well.

b. Downrange means out of capture zone. 
Table B-11. Test Area North/Technical Support Facility.

\begin{tabular}{|c|c|c|c|c|c|c|c|}
\hline \multirow[b]{2}{*}{ Facility } & \multirow[b]{2}{*}{ Well $^{\mathrm{a}}$} & \multirow[b]{2}{*}{ Zone } & \multirow[b]{2}{*}{ Sitecode } & \multicolumn{4}{|c|}{ Potential Contaminant } \\
\hline & & & & & GIS 1 & GIS 2 & GIS 3 \\
\hline TAN/TSF & & Zone $1 \mathrm{~A}$ & TSF-23 & Down Range Area ${ }^{\mathrm{b}}$ & Uncleared & Down Range Area & \\
\hline TAN/TSF & & Zone $1 \mathrm{~A}$ & TSF-23 & Metals and Organics & NA & NA & NA \\
\hline TAN/TSF & & Zone $1 \mathrm{~A}$ & TSF-23 & & & & $\begin{array}{l}\text { TCE concentration } \\
\text { contours }\end{array}$ \\
\hline TAN/TSF & & Zone 1B & TSF-02 & Down Range Area & Uncleared & Down Range Area & \\
\hline TAN/TSF & & Zone 1B & TSF-02 & Organics & $\begin{array}{l}\text { Benzene, Ethylbenzene, } \\
\text { Toluene, Xylene }\end{array}$ & NA & NA \\
\hline TAN/TSF & & Zone 1B & TSF-02 & & & & $\begin{array}{l}\text { TCE concentration } \\
\text { contours }\end{array}$ \\
\hline TAN/TSF & & Zone 1B & TSF-03 & Down Range Area & Uncleared & Down Range Area & \\
\hline TAN/TSF & & Zone 1B & TSF-03 & Inorganics and Rad & $\begin{array}{l}\text { Chromium, Lead, Mercury, } \\
\text { Americium-241, Cesium- } \\
\text { 137, Plutonium-238, } \\
\text { Plutonium-239/240, } \\
\text { Strontium-90, Uranium-234, } \\
\text { Uranium-235, Uranium-238 }\end{array}$ & NA & NA \\
\hline TAN/TSF & & Zone 1B & TSF-06 (1) & Down Range Area & Uncleared & Down Range Area & \\
\hline TAN/TSF & & Zone 1B & TSF-06 (1) & $\operatorname{Rad}$ & Cesium-137, Cobalt-60 & NA & NA \\
\hline TAN/TSF & & Zone 1B & TSF-06 (9) & Down Range Area & Uncleared & Down Range Area & \\
\hline TAN/TSF & & Zone 1B & TSF-06 (9) & $\operatorname{Rad}$ & $\begin{array}{l}\text { Cesium-137, Cobalt-60, } \\
\text { Europium-154, Europium- } \\
155,\end{array}$ & NA & NA \\
\hline TAN/TSF & & Zone 1B & TSF-09 & Down Range Area & Uncleared & Down Range Area & \\
\hline TAN/TSF & & Zone 1B & TSF-09 & Inorganics and Rad & $\begin{array}{l}\text { Barium, Cadmium, } \\
\text { Chromium, Lead, Cesium- } \\
\text { 137, Cobalt- } 60\end{array}$ & NA & NA \\
\hline TAN/TSF & & Zone 1B & TSF-09 & & & & $\begin{array}{l}\text { TCE concentration } \\
\text { contours }\end{array}$ \\
\hline TAN/TSF & & Zone 1B & TSF-12 & Down Range Area & Uncleared & Down Range Area & \\
\hline
\end{tabular}


Table B-11. (continued).

\begin{tabular}{|c|c|c|c|c|c|c|c|}
\hline \multirow[b]{2}{*}{ Facility } & \multirow[b]{2}{*}{ Well $^{\mathrm{a}}$} & \multirow[b]{2}{*}{ Zone } & \multirow[b]{2}{*}{ Sitecode } & \multicolumn{4}{|c|}{ Potential Contaminant } \\
\hline & & & & & GIS 1 & GIS 2 & GIS 3 \\
\hline TAN/TSF & & Zone 1B & TSF-12 & $\begin{array}{l}\text { Inorganics, Organics, a } \\
\operatorname{Rad}\end{array}$ & NA & NA & NA \\
\hline TAN/TSF & & Zone 1B & TSF-12 & & & & $\begin{array}{l}\text { TCE concentration } \\
\text { contours }\end{array}$ \\
\hline TAN/TSF & & Zone 1B & TSF-16 & Down Range Area & Uncleared & Down Range Area & \\
\hline TAN/TSF & & Zone 1B & TSF-16 & & & & $\begin{array}{l}\text { TCE concentration } \\
\text { contours }\end{array}$ \\
\hline TAN/TSF & & Zone 1B & TSF-17 & Acids & NA & NA & NA \\
\hline TAN/TSF & & Zone 1B & TSF-17 & Down Range Area & Uncleared & Down Range Area & \\
\hline TAN/TSF & & Zone 1B & TSF-17 & & & & $\begin{array}{l}\text { TCE concentration } \\
\text { contours }\end{array}$ \\
\hline TAN/TSF & & Zone 1B & TSF-18 & Down Range Area & Uncleared & Down Range Area & \\
\hline TAN/TSF & & Zone 1B & TSF-18 & Metals and Rad & NA & NA & NA \\
\hline TAN/TSF & & Zone 1B & TSF-18 & & & & $\begin{array}{l}\text { TCE concentration } \\
\text { contours }\end{array}$ \\
\hline TAN/TSF & & Zone 1B & TSF-19 & Down Range Area & Uncleared & Down Range Area & \\
\hline TAN/TSF & & Zone 1B & TSF-19 & Metals & NA & NA & NA \\
\hline TAN/TSF & & Zone 1B & TSF-19 & & & & $\begin{array}{l}\text { TCE concentration } \\
\text { contours }\end{array}$ \\
\hline TAN/TSF & & Zone 1B & TSF-20 & Acids & NA & NA & NA \\
\hline TAN/TSF & & Zone 1B & TSF-20 & Down Range Area & Uncleared & Down Range Area & \\
\hline TAN/TSF & & Zone 1B & TSF-20 & & & & $\begin{array}{l}\text { TCE concentration } \\
\text { contours }\end{array}$ \\
\hline TAN/TSF & & Zone 1B & TSF-21 & Down Range Area & Uncleared & Down Range Area & \\
\hline TAN/TSF & & Zone 1B & TSF-21 & $\begin{array}{l}\text { Metals, Organics, and } \\
\text { Rad }\end{array}$ & NA & NA & NA \\
\hline TAN/TSF & & Zone 1B & TSF-21 & & & & $\begin{array}{l}\text { TCE concentration } \\
\text { contours }\end{array}$ \\
\hline TAN/TSF & & Zone 1B & TSF-23 & Down Range Area & Uncleared & Down Range Area & \\
\hline TAN/TSF & & Zone 1B & TSF-23 & Metals and Organics & NA & NA & NA \\
\hline
\end{tabular}


Table B-11. (continued).

\begin{tabular}{|c|c|c|c|c|c|c|c|}
\hline \multirow[b]{2}{*}{ Facility } & \multirow[b]{2}{*}{ Well $^{\mathrm{a}}$} & \multirow[b]{2}{*}{ Zone } & \multirow[b]{2}{*}{ Sitecode } & \multicolumn{4}{|c|}{ Potential Contaminant } \\
\hline & & & & & GIS 1 & GIS 2 & GIS 3 \\
\hline TAN/TSF & & Zone 1B & TSF-23 & & & & $\begin{array}{l}\text { TCE concentration } \\
\text { contours }\end{array}$ \\
\hline TAN/TSF & & Zone 1B & & Down Range Area & Uncleared & Down Range Area & \\
\hline TAN/TSF & & Zone 2 & TSF-06 & Down Range Area & Uncleared & Down Range Area & \\
\hline TAN/TSF & & Zone 2 & TSF-06 & Inorganics and Rad & $\begin{array}{l}\text { Barium, Cadmium, } \\
\text { Chromium, Lead, Mercury, } \\
\text { Cesium-137, Cobalt-60 }\end{array}$ & NA & NA \\
\hline TAN/TSF & & Zone 2 & TSF-06 (1) & Down Range Area & Uncleared & Down Range Area & \\
\hline TAN/TSF & & Zone 2 & TSF-06 (1) & $\operatorname{Rad}$ & Cesium-137, Cobalt- 60 & NA & NA \\
\hline TAN/TSF & & Zone 2 & TSF-06 (1) & & & & $\begin{array}{l}\text { TCE concentration } \\
\text { contours }\end{array}$ \\
\hline TAN/TSF & & Zone 2 & TSF-06 (10) & Down Range Area & Uncleared & Down Range Area & \\
\hline TAN/TSF & & Zone 2 & TSF-06 (10) & Inorganics and Rad & $\begin{array}{l}\text { Barium, Cadmium, } \\
\text { Chromium, Lead, Mercury, } \\
\text { Silver, Cesium-137, }\end{array}$ & NA & NA \\
\hline TAN/TSF & & Zone 2 & TSF-06 (7) & Down Range Area & Uncleared & Down Range Area & \\
\hline TAN/TSF & & Zone 2 & TSF-06 (7) & Inorganics and Rad & $\begin{array}{l}\text { Barium, Cadmium, } \\
\text { Chromium, Lead, Cesium- } \\
137\end{array}$ & NA & NA \\
\hline TAN/TSF & & Zone 2 & TSF-06 (8) & Down Range Area & Uncleared & Down Range Area & \\
\hline TAN/TSF & & Zone 2 & TSF-06 (8) & Down Range Area & Uncleared & Down Range Area & \\
\hline TAN/TSF & & Zone 2 & TSF-06 (8) & $\operatorname{Rad}$ & Cesium-137, Cobalt-60 & NA & NA \\
\hline TAN/TSF & & Zone 2 & TSF-08 & Down Range Area & Uncleared & Down Range Area & \\
\hline TAN/TSF & & Zone 2 & TSF-08 & Inorganics and Rad & $\begin{array}{l}\text { Mercury, Cesium-137, } \\
\text { Cobalt-60 }\end{array}$ & NA & NA \\
\hline TAN/TSF & & Zone 2 & TSF-20 & Acids & NA & NA & NA \\
\hline TAN/TSF & & Zone 2 & TSF-20 & Down Range Area & Uncleared & Down Range Area & \\
\hline TAN/TSF & & Zone 2 & TSF-20 & & & & $\begin{array}{l}\text { TCE concentration } \\
\text { contours }\end{array}$ \\
\hline TAN/TSF & & Zone 2 & TSF-22 & Down Range Area & Uncleared & Down Range Area & \\
\hline
\end{tabular}


Table B-11. (continued).

\begin{tabular}{|c|c|c|c|c|c|c|c|}
\hline \multirow[b]{2}{*}{ Facility } & \multirow[b]{2}{*}{$\mathrm{Well}^{\mathrm{a}}$} & \multirow[b]{2}{*}{ Zone } & \multirow[b]{2}{*}{ Sitecode } & \multicolumn{4}{|c|}{ Potential Contaminant } \\
\hline & & & & & GIS 1 & GIS 2 & GIS 3 \\
\hline TAN/TSF & & Zone 2 & TSF-22 & Inorganics & Mercury & NA & NA \\
\hline TAN/TSF & & Zone 2 & TSF-23 & Down Range Area & Uncleared & Down Range Area & \\
\hline TAN/TSF & & Zone 2 & TSF-23 & Metals and Organics & NA & NA & NA \\
\hline TAN/TSF & & Zone 2 & TSF-23 & & & & $\begin{array}{l}\text { TCE concentration } \\
\text { contours }\end{array}$ \\
\hline TAN/TSF & & Zone 2 & TSF-29 & $\begin{array}{l}\text { Acids, Inorganics, and } \\
\text { Organics }\end{array}$ & $\begin{array}{l}\text { Cadmium, Chromium, Lead, } \\
\text { Acetone, Methylene } \\
\text { chloride, Americium-241, } \\
\text { Cesium-137, Cobalt-60, } \\
\text { Curium-142/143, Curium- } \\
\text { 242, Neptunium-237, } \\
\text { Thorium-230, Thorium-232, } \\
\text { Plutonium-238, Plutonium- } \\
\text { 239/240, Uranium-234, } \\
\text { Uranium-235, Uranium-238 }\end{array}$ & NA & NA \\
\hline TAN/TSF & & Zone 2 & TSF-29 & Down Range Area & Uncleared & Down Range Area & \\
\hline TAN/TSF & & Zone 2 & TSF-43 & Inorganics and Rad & $\begin{array}{l}\text { Mercury, Cesium-137, } \\
\text { Cobalt-60, Uranium-238, }\end{array}$ & NA & NA \\
\hline TAN/TSF & & Zone 2 & & Down Range Area & Uncleared & Down Range Area & \\
\hline TAN/TSF & & Zone 3 & TSF-06 (3) & Down Range Area & Uncleared & Down Range Area & \\
\hline TAN/TSF & & Zone 3 & TSF-06 (3) & $\operatorname{Rad}$ & Cesium-137 & NA & NA \\
\hline TAN/TSF & & Zone 3 & TSF-06 (7) & Down Range Area & Uncleared & Down Range Area & \\
\hline TAN/TSF & & Zone 3 & TSF-06 (7) & Inorganics and Rad & $\begin{array}{l}\text { Barium, Cadmium, } \\
\text { Chromium, Lead, Cesium- } \\
137\end{array}$ & NA & NA \\
\hline TAN/TSF & & Zone 3 & TSF-06 (8) & Down Range Area & Uncleared & Down Range Area & \\
\hline TAN/TSF & & Zone 3 & TSF-06 (8) & $\operatorname{Rad}$ & Cesium-137, Cobalt- 60 & NA & NA \\
\hline TAN/TSF & & Zone 3 & TSF-06 (B) & Down Range Area & Uncleared & Down Range Area & \\
\hline TAN/TSF & & Zone 3 & TSF-06 (B) & Inorganics and Rad & $\begin{array}{l}\text { Barium, Cadmium, } \\
\text { Chromium, Lead, Mercury, } \\
\text { Cesium-137, Cobalt- } 60\end{array}$ & NA & NA \\
\hline
\end{tabular}


Table B-11. (continued).

\begin{tabular}{|c|c|c|c|c|c|c|c|}
\hline \multirow[b]{2}{*}{ Facility } & \multirow[b]{2}{*}{ Well $^{\mathrm{a}}$} & \multirow[b]{2}{*}{ Zone } & \multirow[b]{2}{*}{ Sitecode } & \multicolumn{4}{|c|}{ Potential Contaminant } \\
\hline & & & & & GIS 1 & GIS 2 & GIS 3 \\
\hline TAN/TSF & & Zone 3 & TSF-06 (B) & & & & $\begin{array}{l}\text { TCE concentration } \\
\text { contours }\end{array}$ \\
\hline TAN/TSF & & Zone 3 & TSF-08 & Down Range Area & Uncleared & Down Range Area & \\
\hline TAN/TSF & & Zone 3 & TSF-08 & Inorganics and Rad & $\begin{array}{l}\text { Mercury, Cesium-137, } \\
\text { Cobalt-60 }\end{array}$ & NA & NA \\
\hline TAN/TSF & & Zone 3 & TSF-10 & Down Range Area & Uncleared & Down Range Area & \\
\hline TAN/TSF & & Zone 3 & TSF-10 & Down Range Area & Uncleared & Down Range Area & \\
\hline TAN/TSF & & Zone 3 & TSF-10 & Inorganics and Rad & $\begin{array}{l}\text { Arsenic, Beryllium, } \\
\text { Chromium, Copper, } \\
\text { Manganese, Mercury, } \\
\text { Sodium, Cesium-137, }\end{array}$ & NA & NA \\
\hline TAN/TSF & & Zone 3 & TSF-10 & & & & $\begin{array}{l}\text { TCE concentration } \\
\text { contours }\end{array}$ \\
\hline TAN/TSF & & Zone 3 & TSF-10 & & & & $\begin{array}{l}\text { TCE concentration } \\
\text { contours }\end{array}$ \\
\hline TAN/TSF & & Zone 3 & TSF-23 & Down Range Area & Uncleared & Down Range Area & \\
\hline TAN/TSF & & Zone 3 & TSF-23 & Metals and Organics & NA & NA & NA \\
\hline TAN/TSF & & Zone 3 & TSF-23 & & & & $\begin{array}{l}\text { TCE concentration } \\
\text { contours }\end{array}$ \\
\hline TAN/TSF & & Zone 3 & TSF-31 & Down Range Area & Uncleared & Down Range Area & \\
\hline TAN/TSF & & Zone 3 & TSF-43 & Down Range Area & Uncleared & Down Range Area & \\
\hline TAN/TSF & & Zone 3 & TSF-43 & Inorganics and Rad & $\begin{array}{l}\text { Mercury, Cesium-137, } \\
\text { Cobalt-60, Uranium-238, }\end{array}$ & NA & NA \\
\hline TAN/TSF & & Zone 3 & & Down Range Area & Uncleared & Down Range Area & \\
\hline TAN/TSF & & Zone 3 & & Down Range Area & Uncleared & Down Range Area & \\
\hline TAN/TSF & & Zone 3 & & & & & $\begin{array}{l}\text { TCE concentration } \\
\text { contours }\end{array}$ \\
\hline
\end{tabular}


Table B-12. Test Reactor Area.

\begin{tabular}{|c|c|c|c|c|c|c|c|}
\hline \multirow[b]{2}{*}{ Facility } & \multirow[b]{2}{*}{ Well $^{\mathrm{a}}$} & \multirow[b]{2}{*}{ Zone } & \multirow[b]{2}{*}{ Sitecode } & \multicolumn{4}{|c|}{ Potential Contaminant } \\
\hline & & & & & GIS 1 & GIS 2 & GIS 3 \\
\hline TRA & & Zone $1 \mathrm{~A}$ & & Down Range Area ${ }^{b}$ & Uncleared & Down Range Area & \\
\hline TRA & & Zone $1 \mathrm{~B}$ & TRA-01 & Acids & "Sulfuric Acid" & NA & NA \\
\hline TRA & & Zone 1B & TRA-01 & Down Range Area & Uncleared & Down Range Area & \\
\hline TRA & & Zone 1B & TRA-06 & Down Range Area & Uncleared & Down Range Area & \\
\hline TRA & & Zone 1B & TRA-06 & Inorganics and Organics & $\begin{array}{l}\text { Antimony; Arsenic; Barium; } \\
\text { Beryllium; Cadmium; } \\
\text { Chromium; Cobalt; Copper; } \\
\text { Lead; Manganese; Mercury; } \\
\text { Nickel; Selenium; Silver; } \\
\text { Strontium; Thallium; Tin; } \\
\text { Vanadium; Zinc; Sulfide; } \\
\text { Anthracene; Arocolor-1260 }\end{array}$ & $\begin{array}{l}\text { Bis(2-ethylhexyl)phthalate; } \\
\text { 4-Chloroaniline; } \\
\text { Dibenzofuran; Fluoranthene; } \\
\text { Fluorene; 4-Methly-2- } \\
\text { pentanone; Methylene } \\
\text { chloride; Naphthalene; } \\
\text { Nitrobenzene; 2- } \\
\text { Nitrophenol; and } \\
\text { Phenanthrene }\end{array}$ & NA \\
\hline TRA & & Zone 1B & $\begin{array}{l}\text { TRA-06 Chemical } \\
\text { Waste Pond }\end{array}$ & $\begin{array}{l}\text { Metals (including mercury } \\
\text { and sodium,) sulfate, total } \\
\text { dissolved solids }\end{array}$ & & & \\
\hline TRA & & Zone 1B & TRA-07 & Down Range Area & Uncleared & Down Range Area & \\
\hline TRA & & Zone 1B & TRA-07 & $\begin{array}{l}\text { Inorganics, Organics, and } \\
\text { Rad }\end{array}$ & $\begin{array}{l}\text { Aluminum; Arsenic; } \\
\text { Barium; Beryllium; } \\
\text { Cadmium; Calcium; } \\
\text { Chromium; Cobalt; Copper; } \\
\text { Iron; Lead; Magnesium; } \\
\text { Manganese; Mercury; } \\
\text { Nickel; Potassium; } \\
\text { Selenium; Silver; Sodium; } \\
\text { Vanadium; Acetone; } \\
\text { Benzadiene; Bis(2- } \\
\text { ethylhexyl)phthalate; } \\
\text { Butylbenzylphthalate }\end{array}$ & $\begin{array}{l}\text { Carbon disulfide; 4- } \\
\text { Chloroaniline; Di-n- } \\
\text { butylphthalate; Di-n- } \\
\text { octylphthalate; } \\
\text { Fluoranthene; Pyrene; } \\
\text { 1,1,2,2-Tetrachloroethane; } \\
\text { Toluene; Americium-241; } \\
\text { Cesium-134; Cesium-137; } \\
\text { Cobalt-60; Europium-152, } \\
\text { Europium-154; Plutonium- } \\
\text { 239/240; Silver-108m; }\end{array}$ & $\begin{array}{l}\text { Strontium-90; } \\
\text { Uranium-234; } \\
\text { and Uranium- } \\
238\end{array}$ \\
\hline TRA & & Zone $1 \mathrm{~B}$ & TRA-09 & Down Range Area & Uncleared & Down Range Area & \\
\hline
\end{tabular}


Table B-12. (continued).

\begin{tabular}{|c|c|c|c|c|c|c|c|}
\hline \multirow[b]{2}{*}{ Facility } & \multirow[b]{2}{*}{ Well $^{\mathrm{a}}$} & \multirow[b]{2}{*}{ Zone } & \multirow[b]{2}{*}{ Sitecode } & \multicolumn{4}{|c|}{ Potential Contaminant } \\
\hline & & & & & GIS 1 & GIS 2 & GIS 3 \\
\hline TRA & & Zone 1B & TRA-09 & Organics & $\begin{array}{l}\text { Carbon tetrachloride; } \\
\text { Methylene chloride; } 1,1,2,2- \\
\text { Tetrachloroethane }\end{array}$ & NA & NA \\
\hline TRA & & Zone 1B & TRA-10 & Construction Debris & Concrete and Excavated soil. & NA & NA \\
\hline TRA & & Zone 1B & TRA-10 & Down Range Area & Uncleared & Down Range Area & \\
\hline TRA & & Zone 1B & TRA-12 & Down Range Area & Uncleared & Down Range Area & \\
\hline TRA & & Zone 1B & TRA-12 & Organics & $\begin{array}{l}\text { Benzene; Ethylbenzene; } \\
\text { Naphthalenes; Toluene; and } \\
\text { Xylenes }\end{array}$ & NA & NA \\
\hline TRA & & Zone 1B & TRA-13 & Down Range Area & Uncleared & Down Range Area & \\
\hline TRA & & Zone 1B & TRA-13 & $\begin{array}{l}\text { Inorganics, Organics, and } \\
\text { Rad }\end{array}$ & $\begin{array}{l}\text { Acetone; Cadmium; } \\
\text { Chromium; Copper; Lead; } \\
\text { Mercury; Selenium; Silver; } \\
\text { Zinc; Benzo(b)fluoranthene; } \\
\text { Bis(2-ethylehexyl)phthalate; } \\
\text { Butylbenzylphthalate; } \\
\text { Carbon disulfide; 4- } \\
\text { Chloroaniline; Chrysene; Di- } \\
\text { n-butylphthalate; Di-n- } \\
\text { octylphthalate; Fluoranthene }\end{array}$ & $\begin{array}{l}\text { 4-Methyl-2-pentanone; } \\
\text { Pyrene; 1,1,2,2- } \\
\text { Tetrachloroethane; Toluene; } \\
\text { Cesium-134; Cesium-137; } \\
\text { Cobalt-60; Europium-152; } \\
\text { Europium-154; Plutonium- } \\
\text { 239/240; Silver-108m; } \\
\text { Silver-241; Strontium-90; } \\
\text { and Uranium-234 }\end{array}$ & NA \\
\hline TRA & & Zone 1B & TRA-13 & & & & \\
\hline TRA & & Zone 1B & $\begin{array}{l}\text { TRA-13 Sewage } \\
\text { Pond }\end{array}$ & Nitrate, phosphate, chloride & & & \\
\hline TRA & & Zone 1B & TRA-16 & Down Range Area & Uncleared & Down Range Area & \\
\hline TRA & & Zone 1B & TRA-16 & Inorganics & Mercury & NA & NA \\
\hline TRA & & Zone 1B & TRA-17 & Down Range Area & Uncleared & Down Range Area & \\
\hline TRA & & Zone 1B & TRA-17 & Inorganics and Organics & $\begin{array}{l}\text { Lead; Benzene; } \\
\text { Ethylbenzene; Toluene; and } \\
\text { Xylene }\end{array}$ & NA & NA \\
\hline TRA & & Zone 1B & TRA-18 & Down Range Area & Uncleared & Down Range Area & \\
\hline
\end{tabular}


Table B-12. (continued).

\begin{tabular}{|c|c|c|c|c|c|c|c|}
\hline \multirow[b]{2}{*}{ Facility } & \multirow[b]{2}{*}{ Well $^{\mathrm{a}}$} & \multirow[b]{2}{*}{ Zone } & \multirow[b]{2}{*}{ Sitecode } & \multicolumn{4}{|c|}{ Potential Contaminant } \\
\hline & & & & & GIS 1 & GIS 2 & GIS 3 \\
\hline TRA & & Zone 1B & TRA-18 & Inorganics and Organics & $\begin{array}{l}\text { Lead; Benzene; } \\
\text { Ethylbenzene; Toluene; and } \\
\text { Xylene }\end{array}$ & NA & NA \\
\hline TRA & & Zone 1B & TRA-20 & Acids, Bases, and Inorganics & $\begin{array}{l}\text { Sodium Chloride, Sodium } \\
\text { hydroxide, and Sulfuric acid }\end{array}$ & NA & NA \\
\hline TRA & & Zone 1B & TRA-20 & Down Range Area & Uncleared & Down Range Area & \\
\hline TRA & & Zone 1B & TRA-25 & Construction Debris & Excavated soil & NA & NA \\
\hline TRA & & Zone 1B & TRA-25 & Down Range Area & Uncleared & Down Range Area & \\
\hline TRA & & Zone 1B & TRA-26 & Construction Debris & Concrete and Excavated soil. & NA & NA \\
\hline TRA & & Zone 1B & TRA-26 & Down Range Area & Uncleared & Down Range Area & \\
\hline TRA & & Zone $1 \mathrm{~B}$ & TRA-26 & & & & \\
\hline TRA & & Zone 1B & TRA-27 & Construction Debris & Construction debris & NA & NA \\
\hline TRA & & Zone 1B & TRA-27 & Down Range Area & Uncleared & Down Range Area & \\
\hline TRA & & Zone 1B & TRA-34 & Down Range Area & Uncleared & Down Range Area & \\
\hline TRA & & Zone 1B & TRA-34 & Organics and Rad & $\begin{array}{l}\text { Acetone, Cesium-137, } \\
\text { Cobalt-60, Euoprium-152, } \\
\text { Silver-108m, and Strontium- } \\
90\end{array}$ & NA & NA \\
\hline TRA & & Zone 1B & TRA-38 & Down Range Area & Uncleared & Down Range Area & \\
\hline TRA & & Zone 1B & TRA-38 & Inorganics & Chromium-VI & NA & NA \\
\hline TRA & & Zone $1 \mathrm{~B}$ & TRA-39 & Down Range Area & Uncleared & Down Range Area & \\
\hline TRA & & Zone 1B & TRA-39 & Inorganics & Chromium-VI & NA & NA \\
\hline TRA & & Zone 1B & TRA-40 & Acids, Bases, and Inorganics & $\begin{array}{l}\text { Sodium Chloride, Sodium } \\
\text { hydroxide, and Sulfuric acid }\end{array}$ & NA & NA \\
\hline TRA & & Zone 1B & TRA-40 & Down Range Area & Uncleared & Down Range Area & \\
\hline TRA & & Zone 1B & TRA-42 & Down Range Area & Uncleared & Down Range Area & \\
\hline TRA & & Zone 1B & TRA-42 & Fuel Oil & NA & NA & NA \\
\hline
\end{tabular}


Table B-12. (continued).

\begin{tabular}{|c|c|c|c|c|c|c|c|}
\hline \multirow[b]{2}{*}{ Facility } & \multirow[b]{2}{*}{ Well $^{\mathrm{a}}$} & \multirow[b]{2}{*}{ Zone } & \multirow[b]{2}{*}{ Sitecode } & \multicolumn{4}{|c|}{ Potential Contaminant } \\
\hline & & & & & GIS 1 & GIS 2 & GIS 3 \\
\hline TRA & & Zone 1B & TRA-56 & Acids & NA & NA & NA \\
\hline TRA & & Zone 1B & TRA-56 & Acids & NA & NA & NA \\
\hline TRA & & Zone 1B & TRA-56 & Acids & NA & NA & NA \\
\hline TRA & & Zone 1B & TRA-56 & Down Range Area & Uncleared & Down Range Area & \\
\hline TRA & & Zone 1B & TRA-56 & Down Range Area & Uncleared & Down Range Area & \\
\hline TRA & & Zone 1B & TRA-57 & Down Range Area & Uncleared & Down Range Area & \\
\hline TRA & & Zone 1B & TRA-57 & Down Range Area & Uncleared & Down Range Area & \\
\hline TRA & & Zone 1B & TRA-57 & Down Range Area & Uncleared & Down Range Area & \\
\hline TRA & & Zone 1B & TRA-57 & Fuel Oil & NA & NA & NA \\
\hline TRA & & Zone 1B & TRA-58 & Down Range Area & Uncleared & Down Range Area & \\
\hline TRA & & Zone 1B & TRA-58 & Fuel Oil & NA & NA & NA \\
\hline TRA & & Zone 1B & TRA-59 & Acids & NA & NA & NA \\
\hline TRA & & Zone 1B & TRA-59 & Down Range Area & Uncleared & Down Range Area & \\
\hline TRA & & Zone 1B & TRA-60 & Acids and Inorganics & Lead, Mercury, St & NA & NA \\
\hline TRA & & Zone 1B & TRA-60 & Down Range Area & Uncleared & Down Range Area & \\
\hline TRA & & Zone 1B & TRA-603/605 & Down Range Area & Uncleared & Down Range Area & \\
\hline TRA & & Zone 1B & TRA-603/605 & $\mathrm{Rad}$ & NA & NA & NA \\
\hline TRA & & Zone 1B & TRA-619 & Down Range Area & Uncleared & Down Range Area & \\
\hline TRA & & Zone 1B & TRA-619 & PCBs & Aroclor-1260 & NA & NA \\
\hline TRA & & Zone 1B & TRA-62 & Down Range Area & Uncleared & Down Range Area & \\
\hline TRA & & Zone 1B & TRA-62 & $\begin{array}{l}\text { Inorganics, Organics, } \\
\text { Metals, and Rad }\end{array}$ & NA & NA & NA \\
\hline TRA & & Zone 1B & TRA-627 & Down Range Area & Uncleared & Down Range Area & \\
\hline
\end{tabular}


Table B-12. (continued).

\begin{tabular}{|c|c|c|c|c|c|c|c|}
\hline \multirow[b]{2}{*}{ Facility } & \multirow[b]{2}{*}{ Well $^{\mathrm{a}}$} & \multirow[b]{2}{*}{ Zone } & \multirow[b]{2}{*}{ Sitecode } & \multicolumn{4}{|c|}{ Potential Contaminant } \\
\hline & & & & & GIS 1 & GIS 2 & GIS 3 \\
\hline TRA & & Zone 1B & TRA-627 & Organics & $\begin{array}{l}\text { Anthracene; } \\
\text { Benzo(a)pyrene; Chrysene; } \\
\text { Fluoranthene; Phenanthrene; } \\
\text { and Pyrene }\end{array}$ & NA & NA \\
\hline TRA & & Zone 1B & TRA-670 & Down Range Area & Uncleared & Down Range Area & \\
\hline TRA & & Zone 1B & TRA-670 & Inorganics & $\begin{array}{l}\text { Cadmium, Chromium, and } \\
\text { Lead }\end{array}$ & NA & NA \\
\hline TRA & & Zone 1B & TRA-SCA & Down Range Area & Uncleared & Down Range Area & \\
\hline TRA & & Zone 1B & TRA-SCA & Down Range Area & Uncleared & Down Range Area & \\
\hline TRA & & Zone 1B & TRA-SCA & Rad & $\begin{array}{l}\text { Americium-241, Cesium- } \\
\text { 137, Cobalt-60, Silver- } \\
\text { 108m, and Strontium-90 }\end{array}$ & NA & NA \\
\hline TRA & & Zone 1B & TRA-SCA & & & & \\
\hline TRA & & Zone 1B & & Down Range Area & Uncleared & Down Range Area & \\
\hline TRA & & Zone 2 & & Down Range Area & Uncleared & Down Range Area & \\
\hline TRA & & Zone 2 & & Down Range Area & Uncleared & Down Range Area & \\
\hline TRA & & Zone 2 & & Fuze Burn Area 1 & Cleared & Cleared Ordnance Area & \\
\hline TRA & & Zone 2 & & Fuze Burn Area 2 & Cleared & Cleared Ordnance Area & \\
\hline TRA & & Zone 2 & & Fuze Burn Area 3 & Cleared & Cleared Ordnance Area & \\
\hline TRA & & Zone 2 & & Fuze Burn Area 4 & Failed QC & $\begin{array}{l}\text { UXO Area that Failed } \\
\text { Quality Control Inspection }\end{array}$ & \\
\hline TRA & & Zone 2 & & Fuze Burn Area 5 & Failed QC & $\begin{array}{l}\text { UXO Area that Failed } \\
\text { Quality Control Inspection }\end{array}$ & \\
\hline TRA & & Zone 2 & & $\begin{array}{l}\text { Land Mine And Fuze Burn } \\
\text { Area }\end{array}$ & Surface Cleared & Cleared Ordnance Area & \\
\hline
\end{tabular}


Table B-12. (continued).

\begin{tabular}{|c|c|c|c|c|c|c|}
\hline \multirow[b]{2}{*}{ Facility } & \multirow[b]{2}{*}{ Well $^{\mathrm{a}}$} & \multirow[b]{2}{*}{ Zone } & & \multicolumn{3}{|c|}{ Potential Contaminant } \\
\hline & & & Sitecode & GIS 1 & GIS 2 & GIS 3 \\
\hline TRA & & Zone 3 & Down Range Area & Uncleared & Down Range Area & \\
\hline
\end{tabular}




\section{APPENDIX C}

As-Built Drawings for INEEL Public Water System Wells 



\section{APPENDIX C}

\section{As-Built Drawings for INEEL Public Water System Wells}

CFA \#1 Potable Water Well

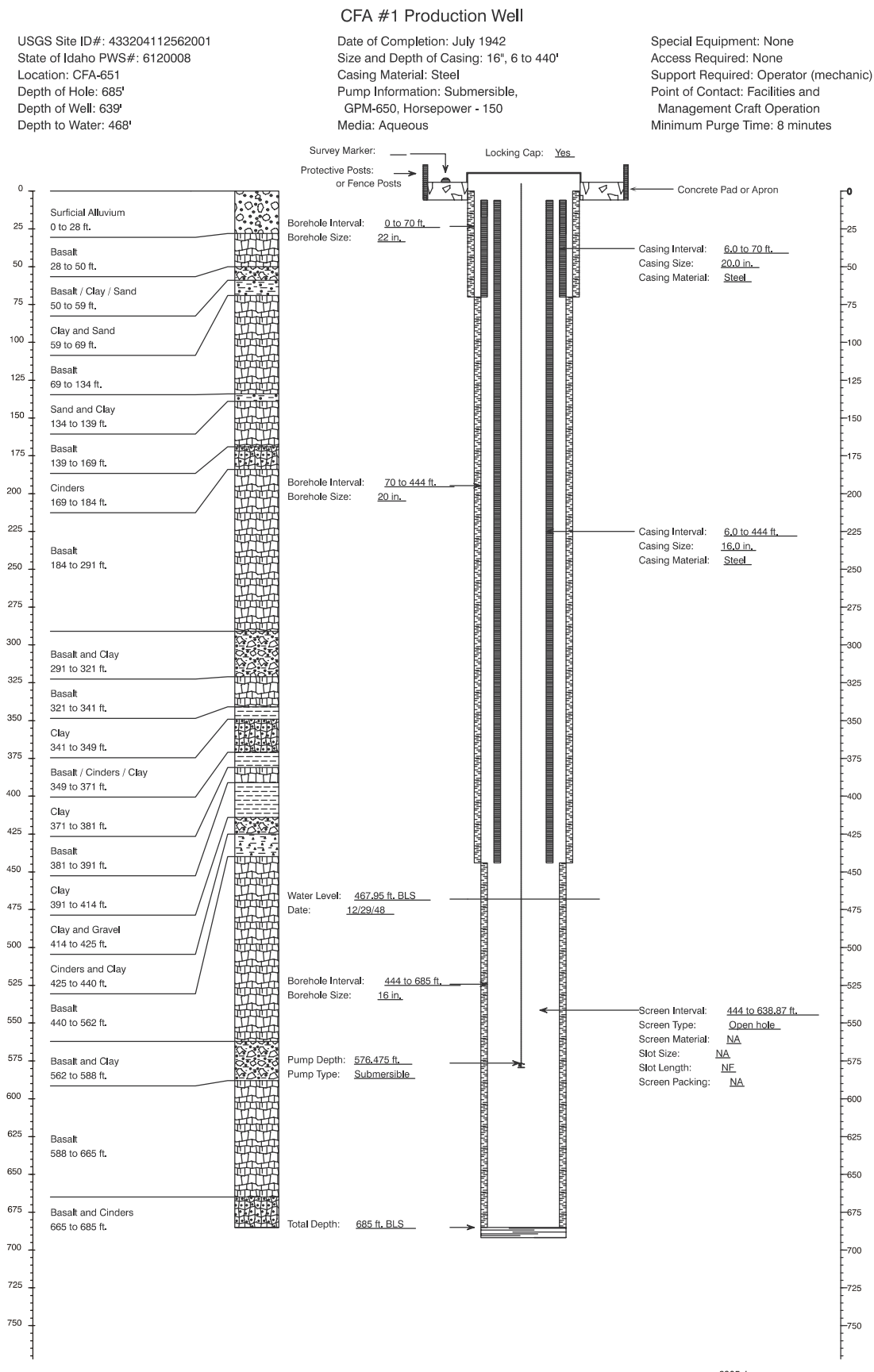

C-1 


\section{CFA \#2 Potable Water Well}

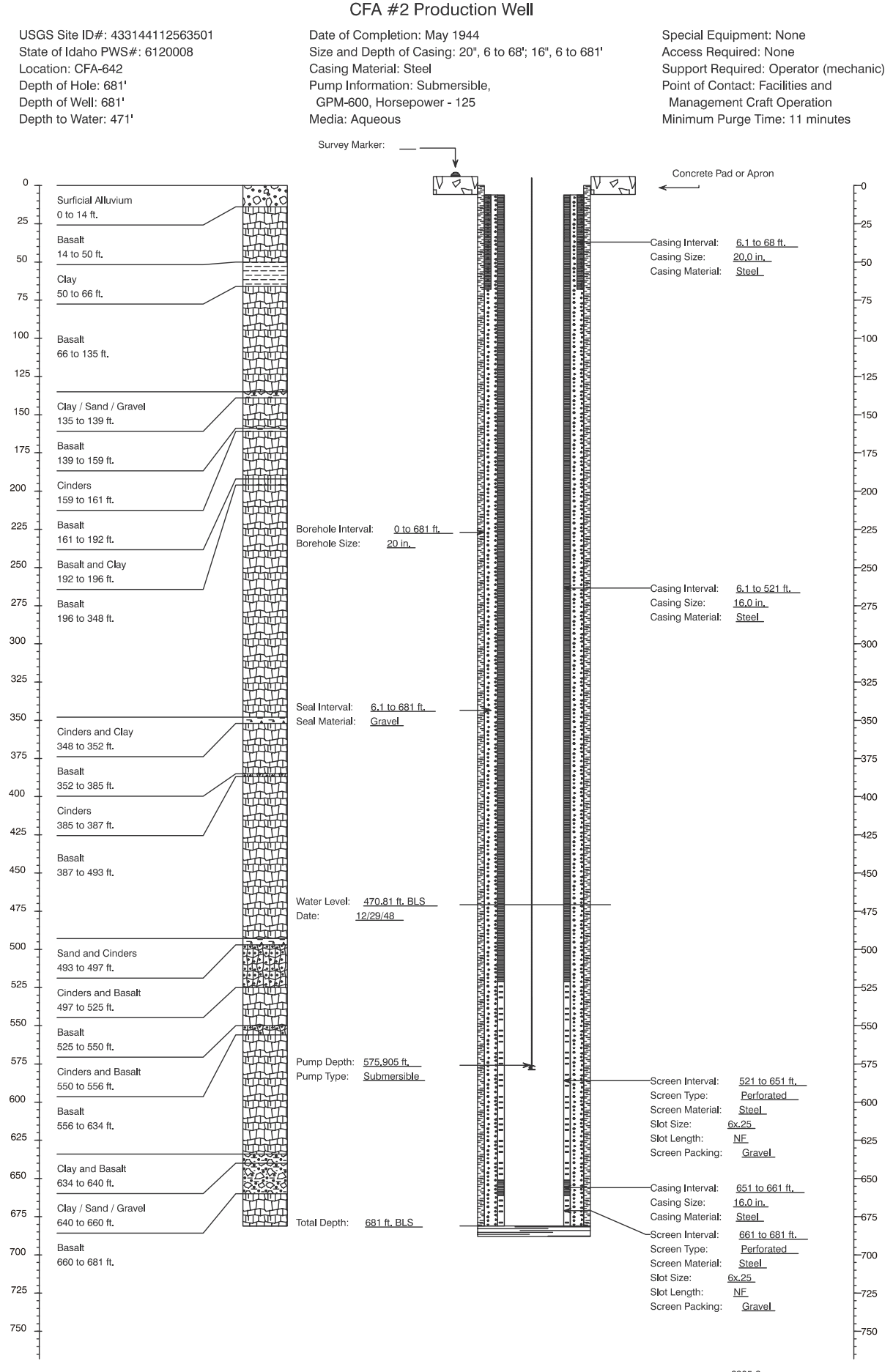




\section{CPP \#4 Potable Water Well}

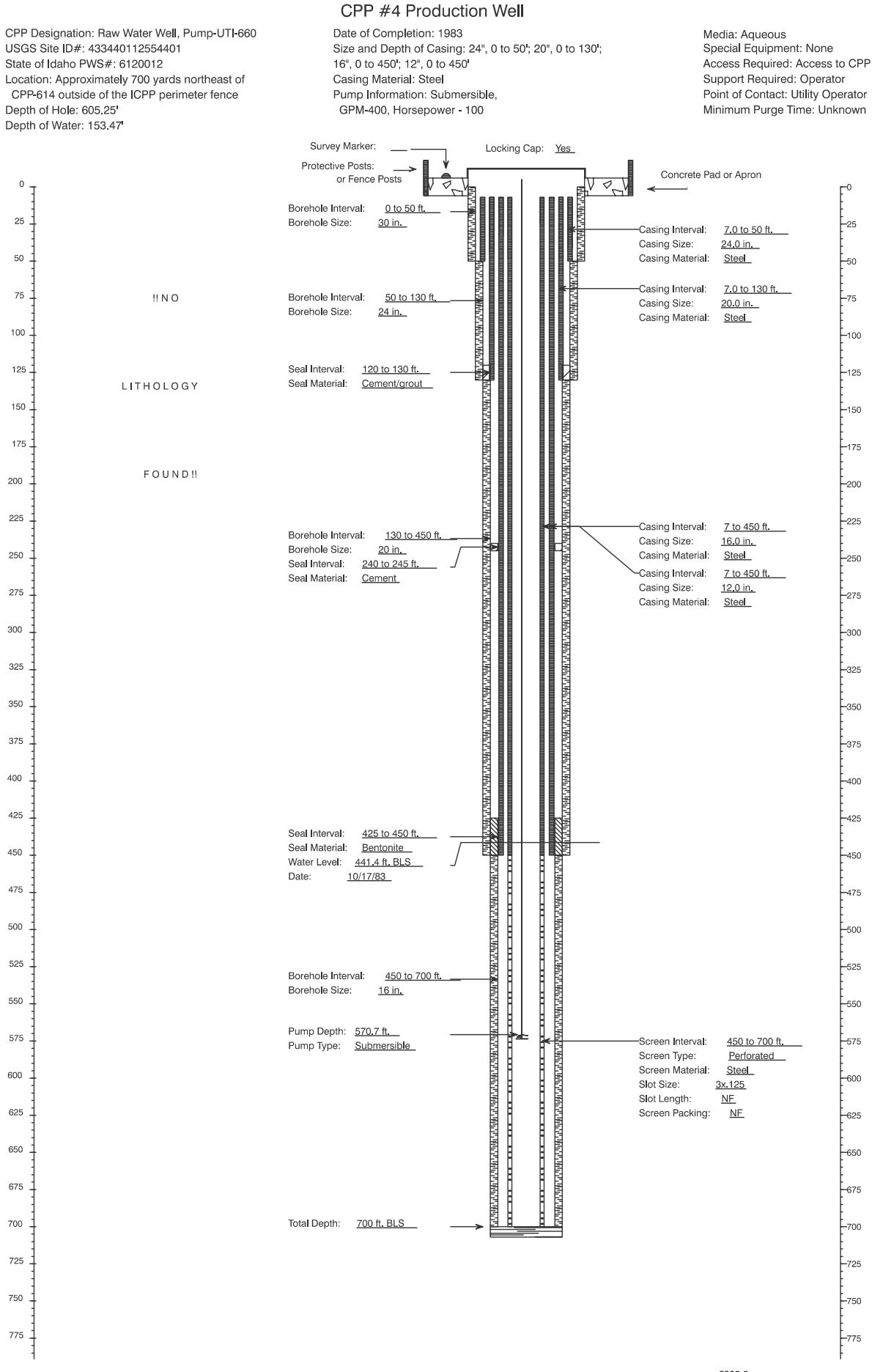

6905-5 


\section{CPP \#5 Potable Water Well}
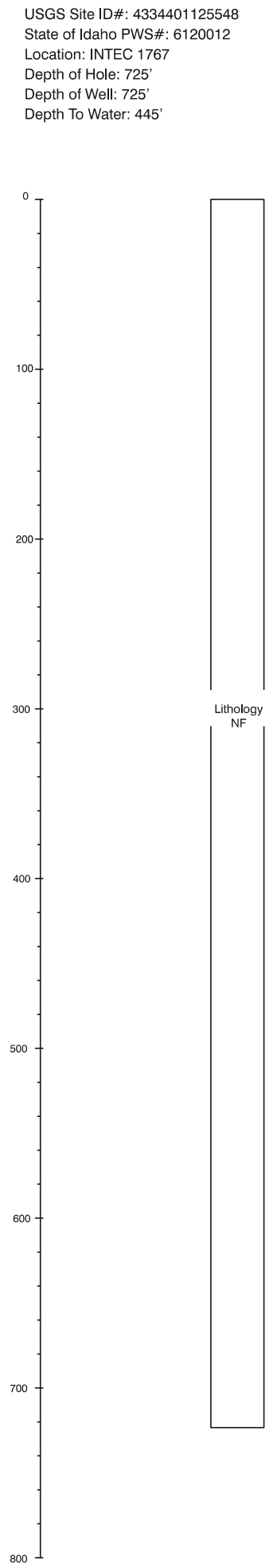

CPP \#5 Production Well

Date of Completion: 1901

$\begin{array}{ll}\text { Size and Depth of Casing: } 12 ", 410 \text { to } 7255^{\prime} & \text { Access Required: Confined Space } \\ \text { Casing Material: Steel } & \text { Support Required: Operator }\end{array}$

Casing Material: Steel

Support Required: Operator

tion: Submersible,

Minimum Purge Time: 3 minutes

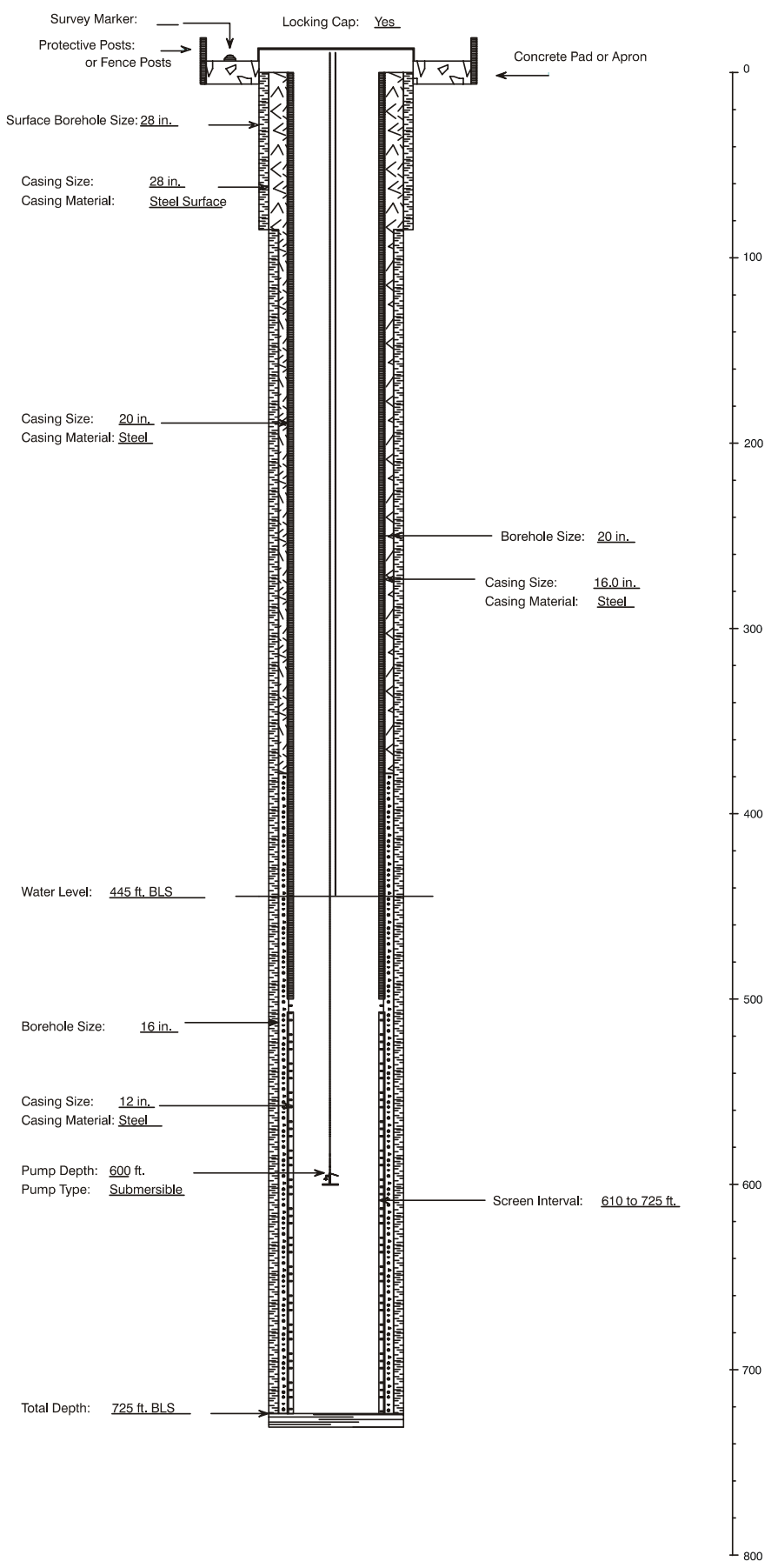

GZ00 0418 


\section{CTF \#1 Potable Water Well}

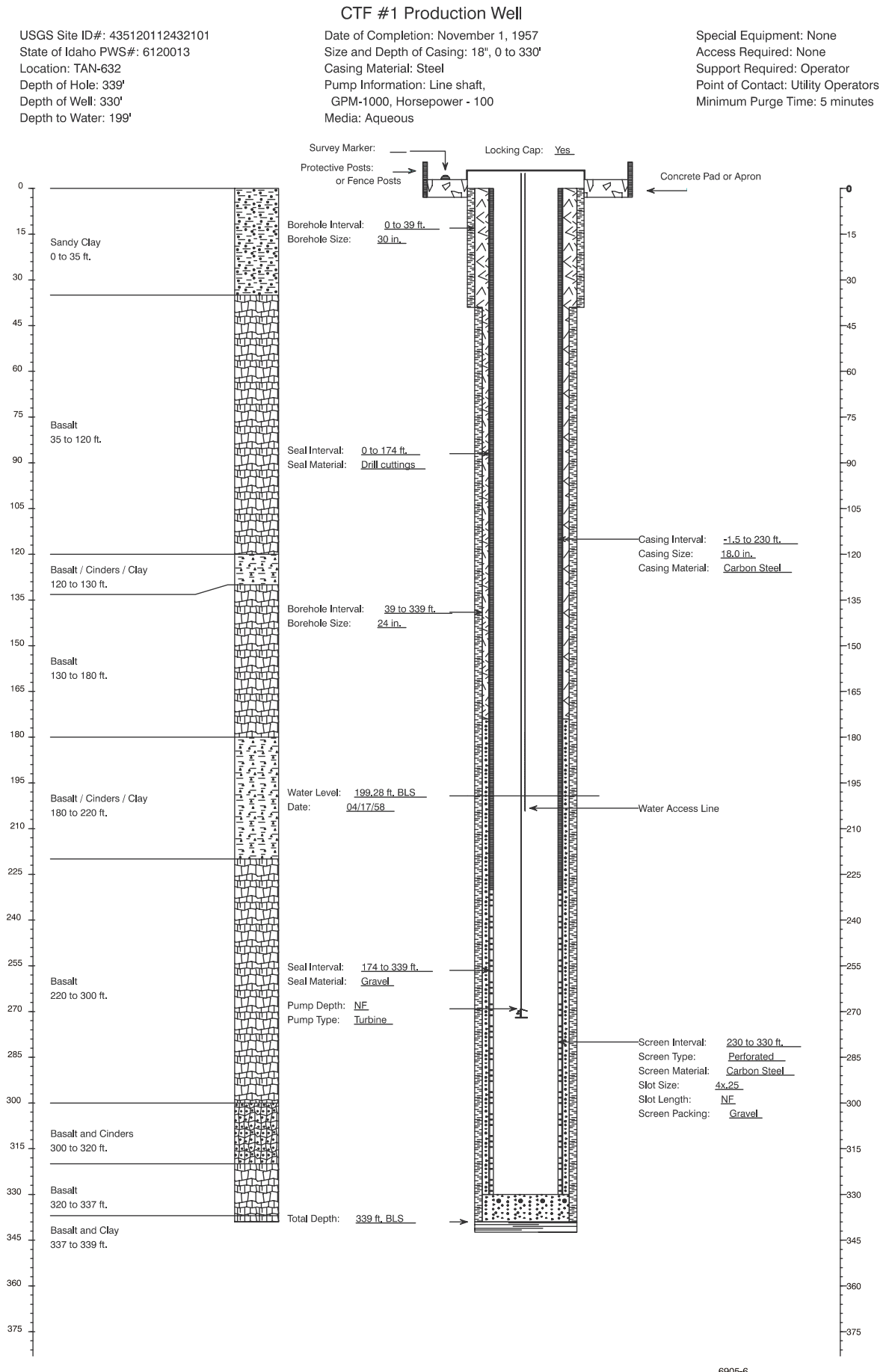




\section{CTF \#2 Potable Water Well}
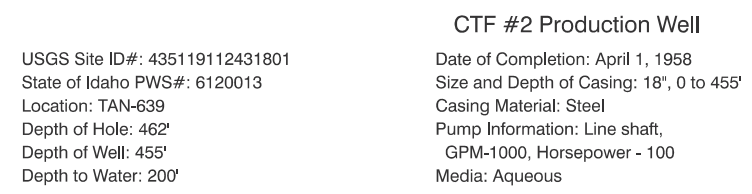

Date of Completion: April 1, 1958

Size and Depth of Casing: 18", 0 to $455^{\prime}$

Casing Material: Steel

Pump Information: Line shaft,

GPM-1000, Horsepower - 100

Media: Aqueous

Access Required: None

Support Required: Operator

Pint Contact: Utility operators

Depth to Water: 200

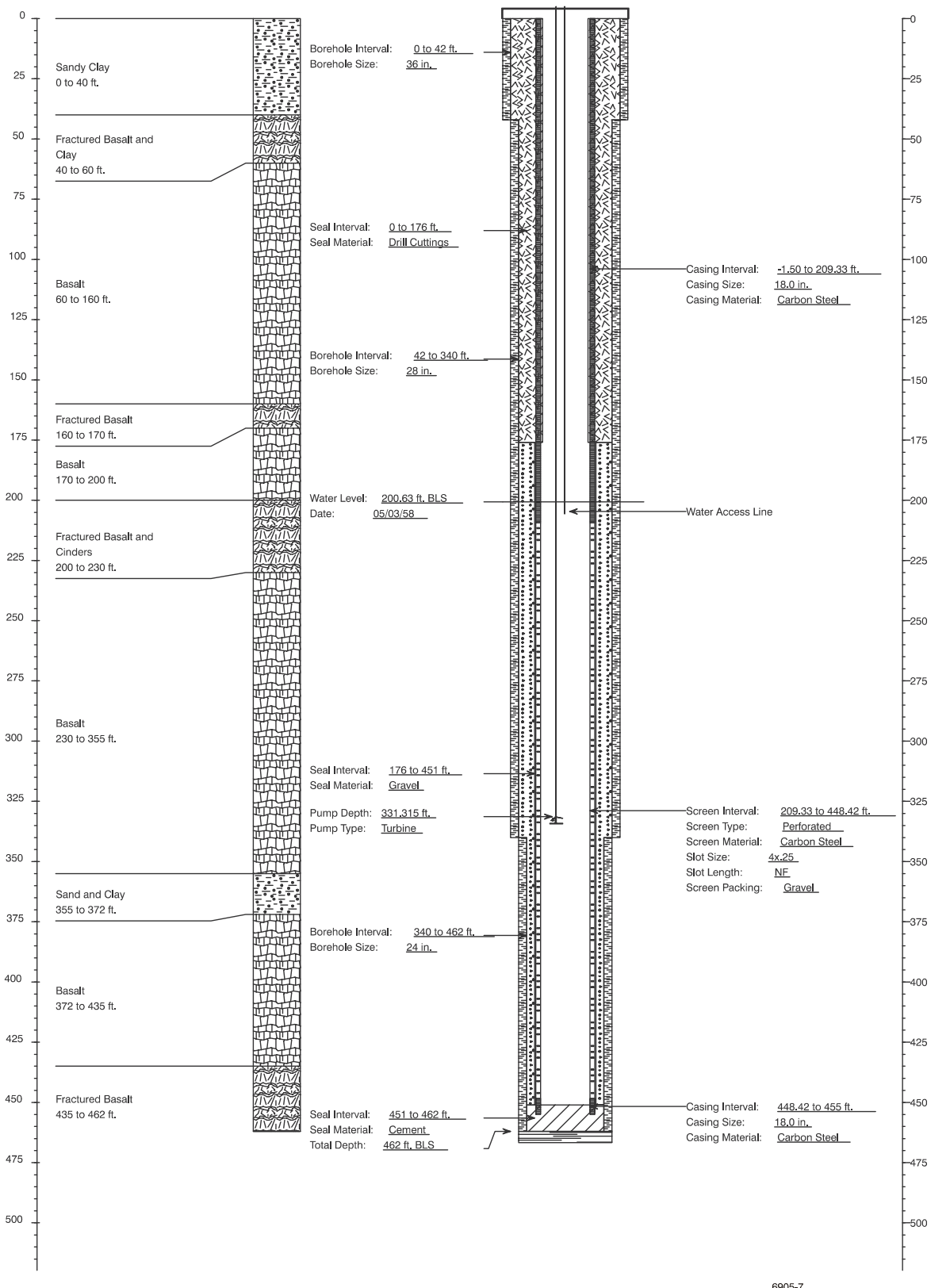




\section{EBR-I Potable Water Well}

USGS Site ID\#: 433051113002601 State of Idaho PWSA: 61 Location: EBR-I, EBR-711

Depth of Hole: 1075

Depth of Well: 1075

Depth to Water: 596

${ }^{0} \mathrm{~J}$

\begin{tabular}{l} 
Sitt \\
0 to $14 \mathrm{tt}$ \\
\hline
\end{tabular}

70 Bas

105

140

175 130 to $150 \mathrm{ft}$.

210 Basalt and Clay 150 to $170 \mathrm{ft}$.

245 Cinder 170 to

280

70 to $180 \mathrm{ft}$.

315 Clay

350 Basalt

385226 to 243

Basalt
250 to $307 \mathrm{ft}$

455 Gravel and $\mathrm{C}$

490

525

560

595

630

665

700

735

770

805

840

875

9107

945

980

1015

1050

1085

680 to $904 \mathrm{ft}$

$120-7$ Cinders and Clay

Basalt and Clay
979 to $1075 \mathrm{ft}$.

1190 年

307 to $324 \mathrm{ft}$.

24 to $338 \mathrm{ft}$.

338 to $368 \mathrm{ft}$

Basalt and Clay
368 to $385 \mathrm{ft}$.

Basalt
385 to $530 \mathrm{ft}$.

Clay 530 to $534 \mathrm{ft}$

Basalt
534 to $570 \mathrm{ft}$

lay and Basalt

Basalt
575 to $590 \mathrm{ft}$

Clay and Basalt
90 to $598 \mathrm{ft}$.

Basalt
598 to $640 \mathrm{ft}$.

Sand
640 to $643 \mathrm{ft}$

Basalt
643 to $664 \mathrm{ft}$

Cinders
664 to $671 \mathrm{ft}$

Clay

$10680 \mathrm{ft}$.

79 to $1075 \mathrm{ft}$.

EBR \#I Production Well

Date of Completion: May 1949

Size and Depth of Casing: 18" 6 to $750^{\prime}$ Casing Material: Stee

Pump Information: Submersible,

ower - 200

Media: Aqueous
Special Equipment: None

Access Required: Confined space permit

(required for work, not for routine sampling)

Support Required: Operator (mechanic)

Point of Contact. (CFA) Facilties and

Management Craft Operation

Minimum Purge Time: 24 minutes

Borehole Interval: $\quad \underline{0 \text { to } 750}$
Borehole Size: $\underline{22 \text { in. }}$
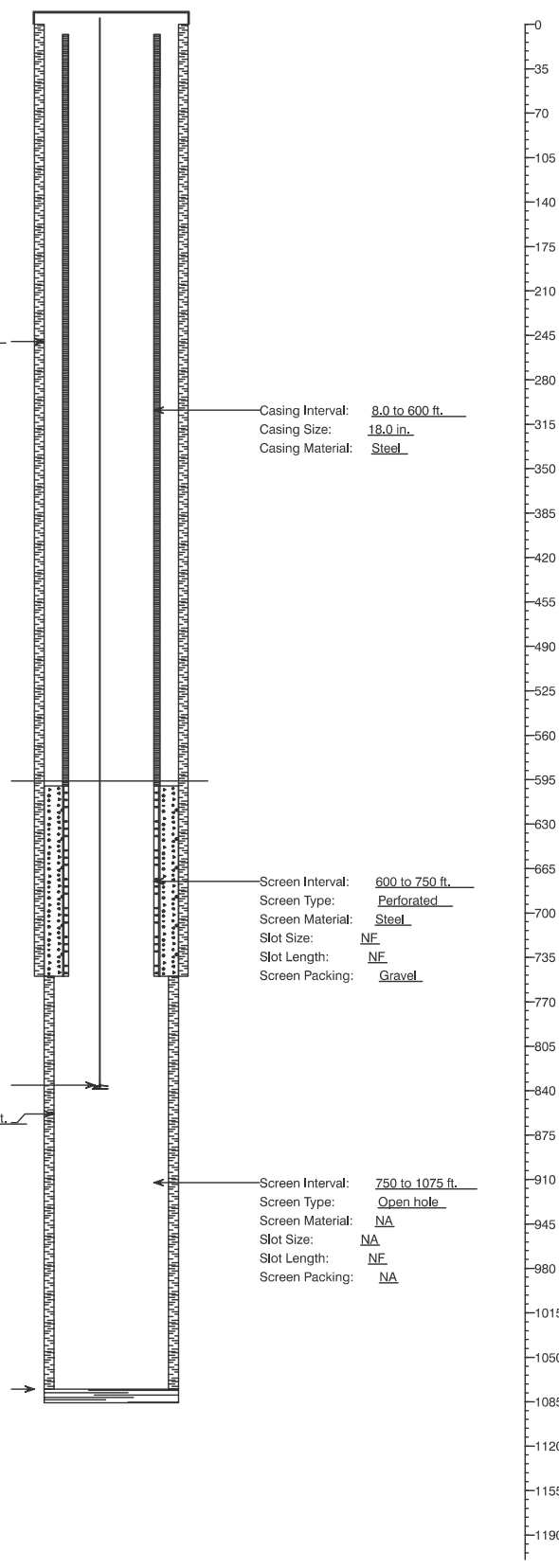

$6905-8$ 


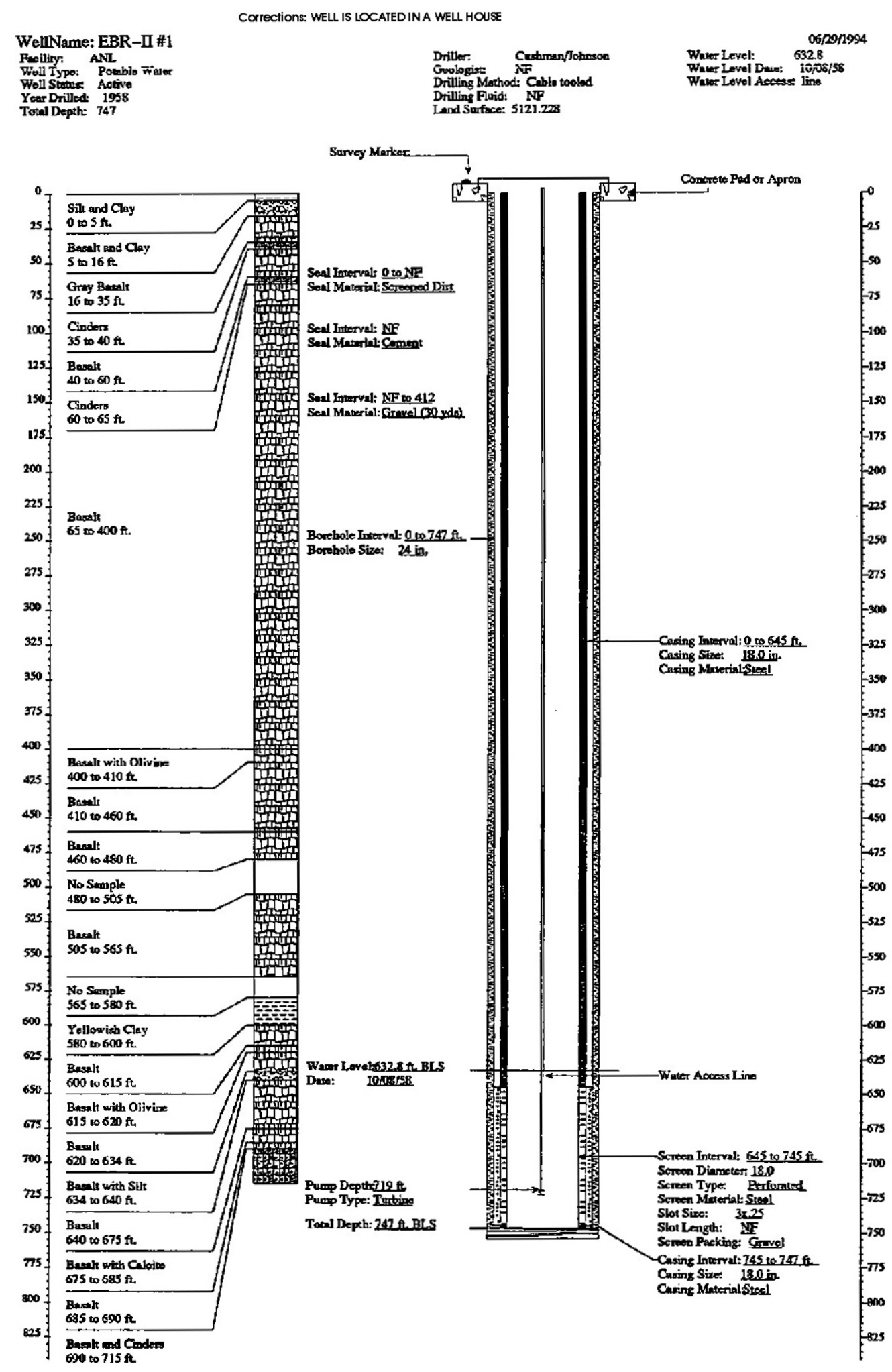




\section{EBR-II \#2 Potable Water Well}

\begin{tabular}{|c|c|c|}
\hline WellName: EBR-II \#2 & Corcections:WELL IS LOCATFD IN A WELL HOUSE & $09 / 11 / 1993$ \\
\hline $\begin{array}{l}\text { Feeility: ANL } \\
\text { Well Typo: Potuble Water Well } \\
\text { Well Stalus: Active } \\
\text { Year Drilled: } 1959 \\
\text { Total Depthe } 753\end{array}$ & $\begin{array}{ll}\text { Driller: } \quad \text { Andrew } \\
\text { Goologist: NT } \\
\text { Drilling Meshod: Cable tooled } \\
\text { Drilling Fuid: } \mathrm{NF} \\
\text { T.and Surface: S120.7 }\end{array}$ & $\begin{array}{l}\text { Water Lovel: } \quad 629.25 \\
\text { Water Level Date: } 11 / 11 / 59 \\
\text { Water Lovel Access: line }\end{array}$ \\
\hline
\end{tabular}

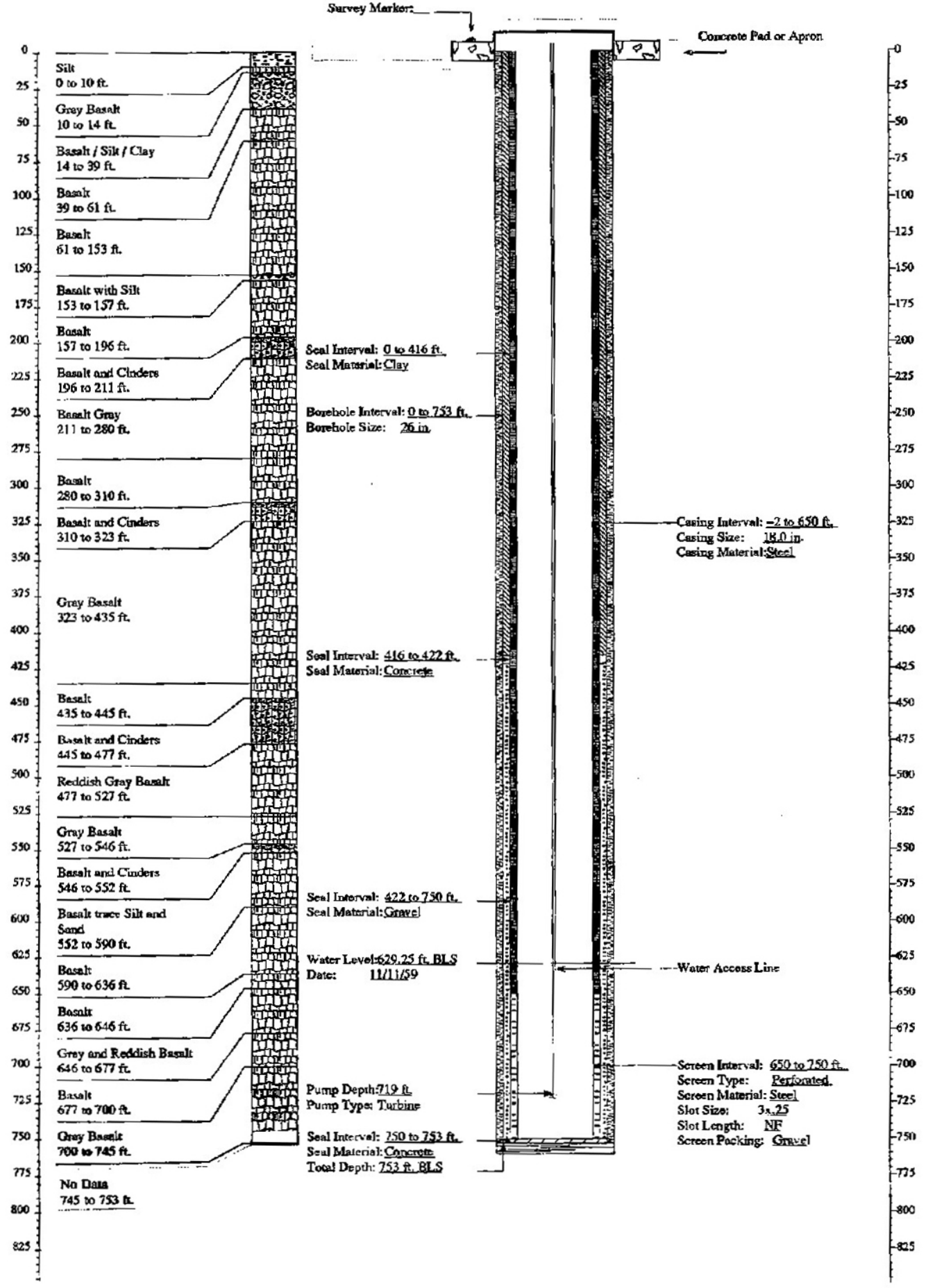




\section{Gun Range Potable Water Well}
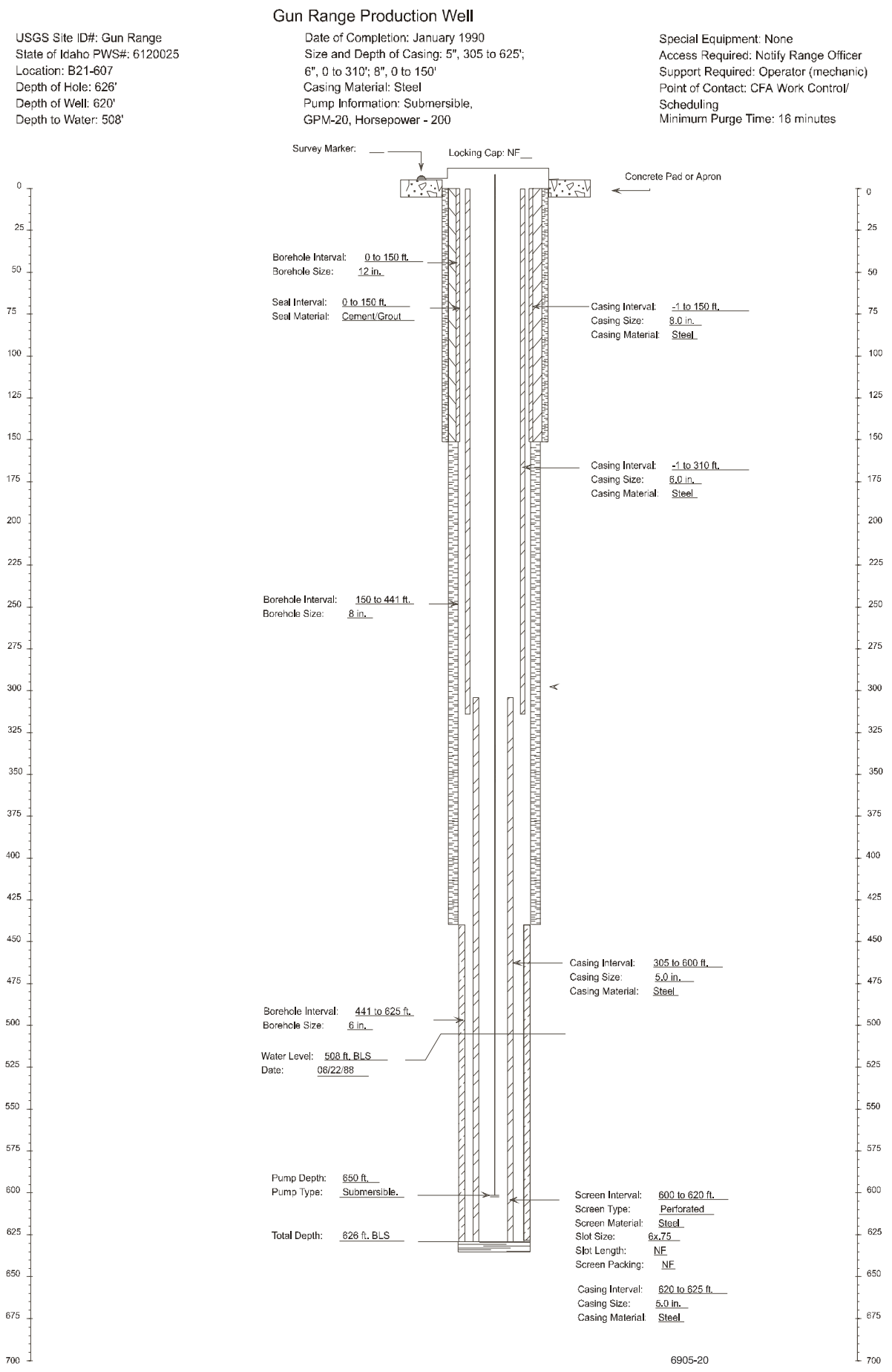
Main Gate Potable Water Well

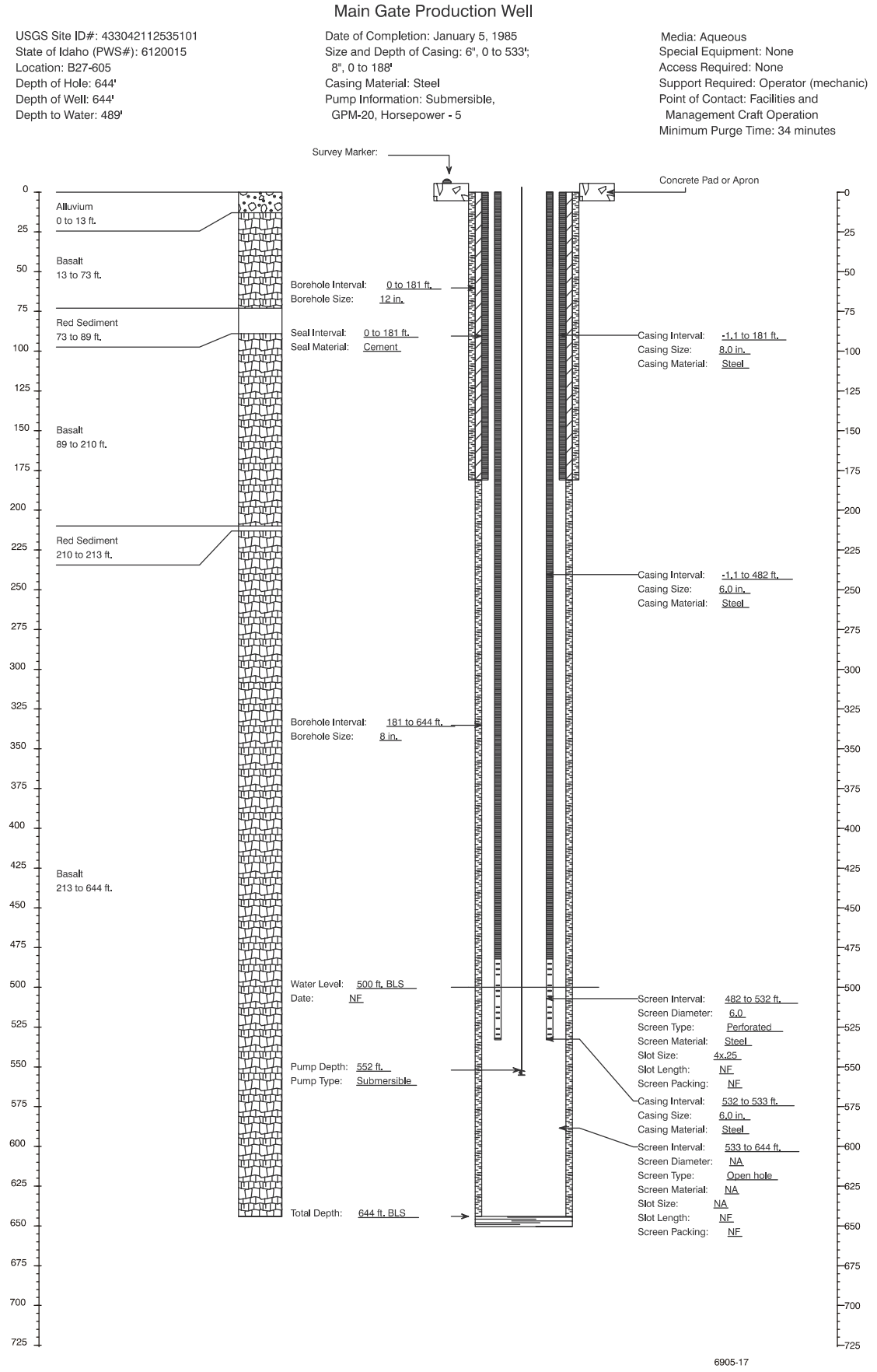


NRF \#2 Potable Water Well

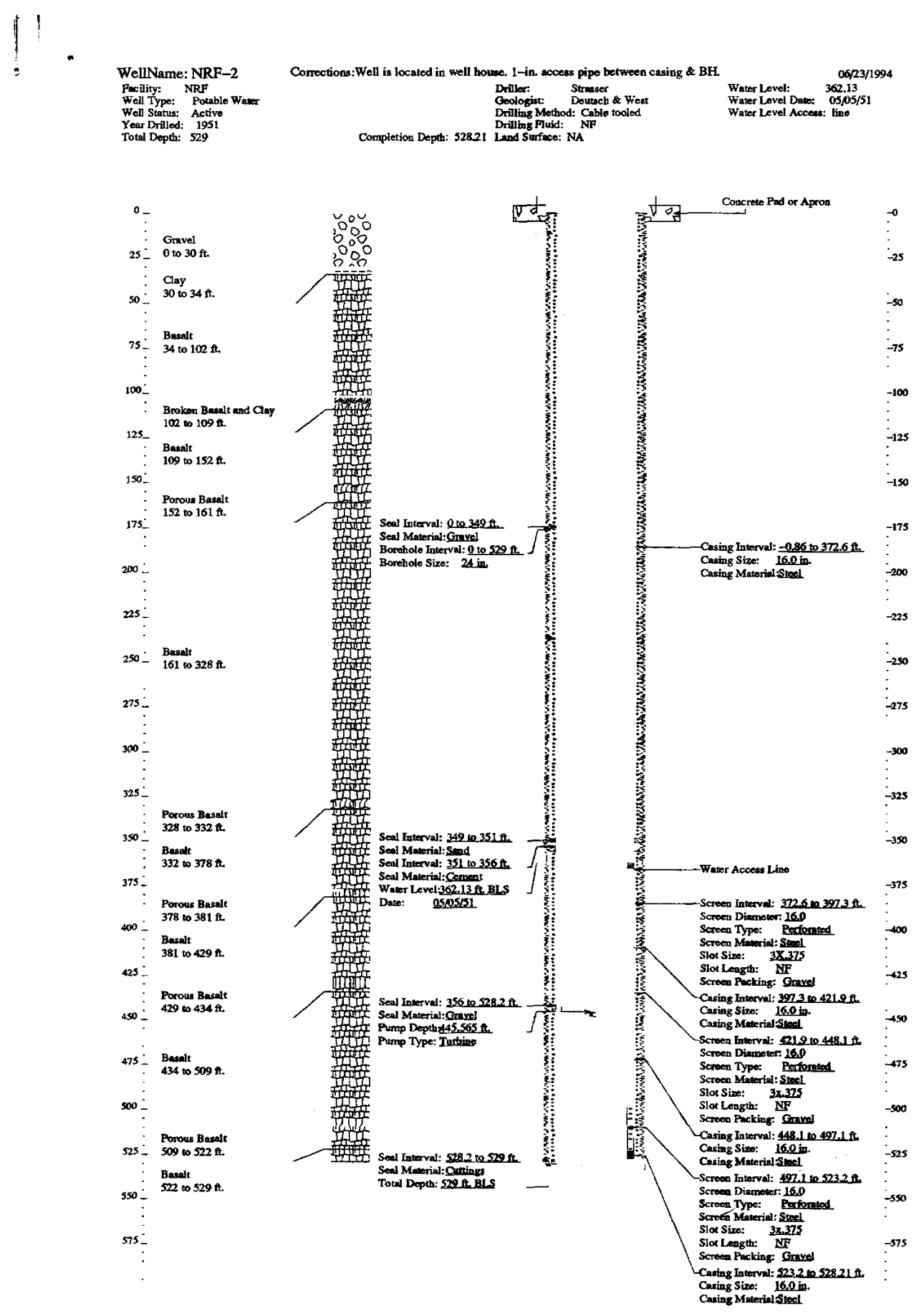


NRF \#3 Potable Water Well
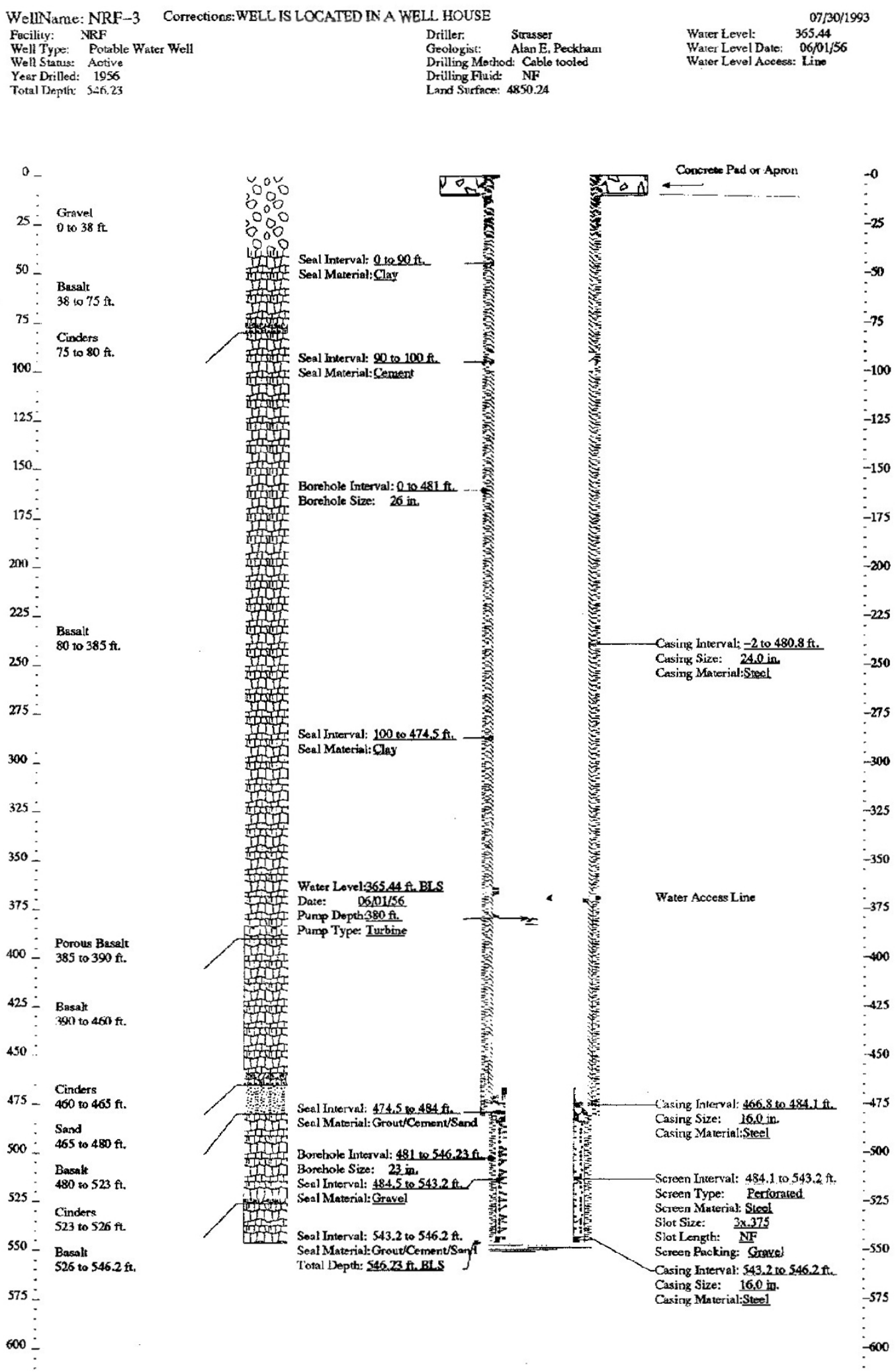


\section{PBF \#1 Potable Water Well}

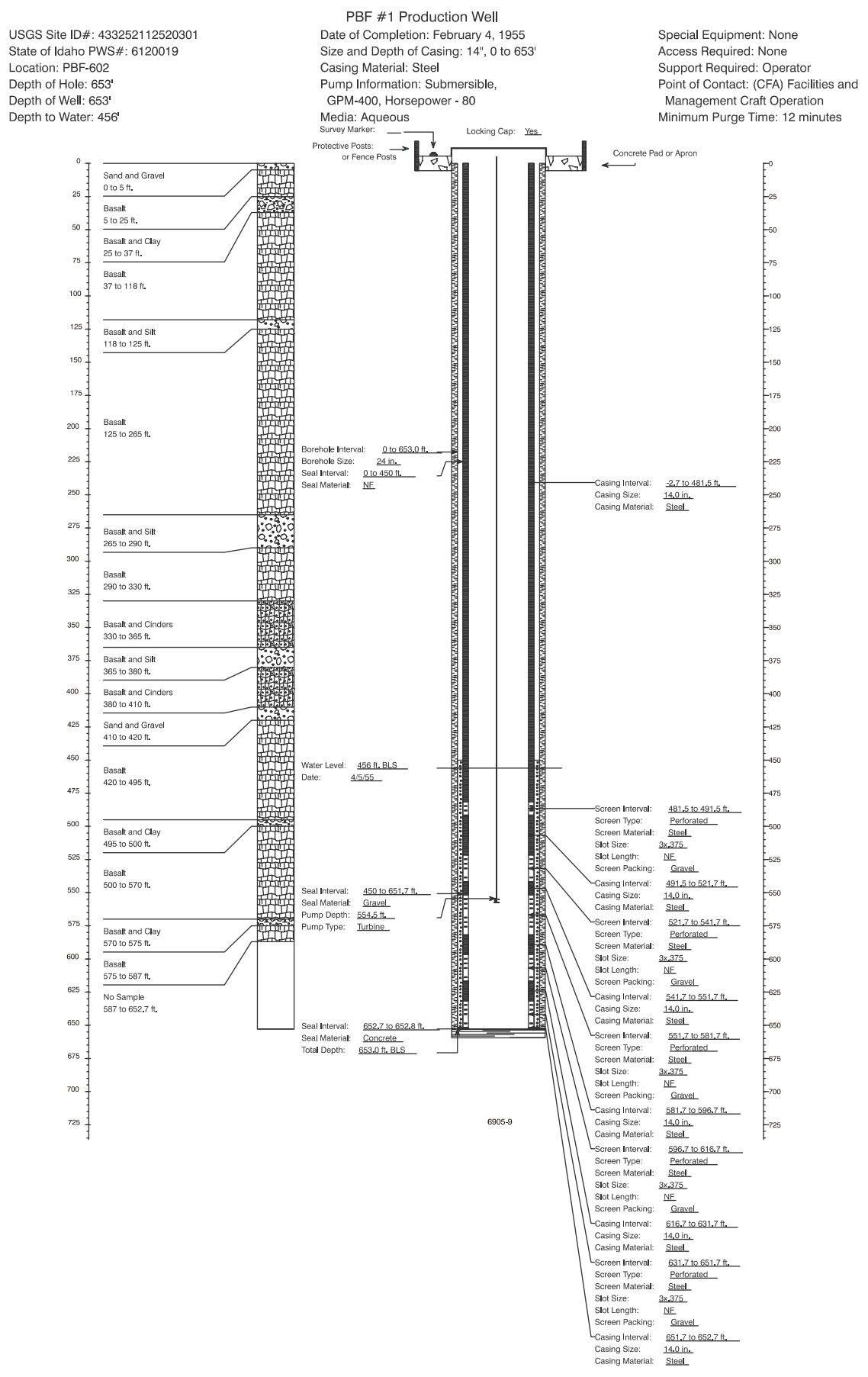


PBF \#2 Potable Water Well

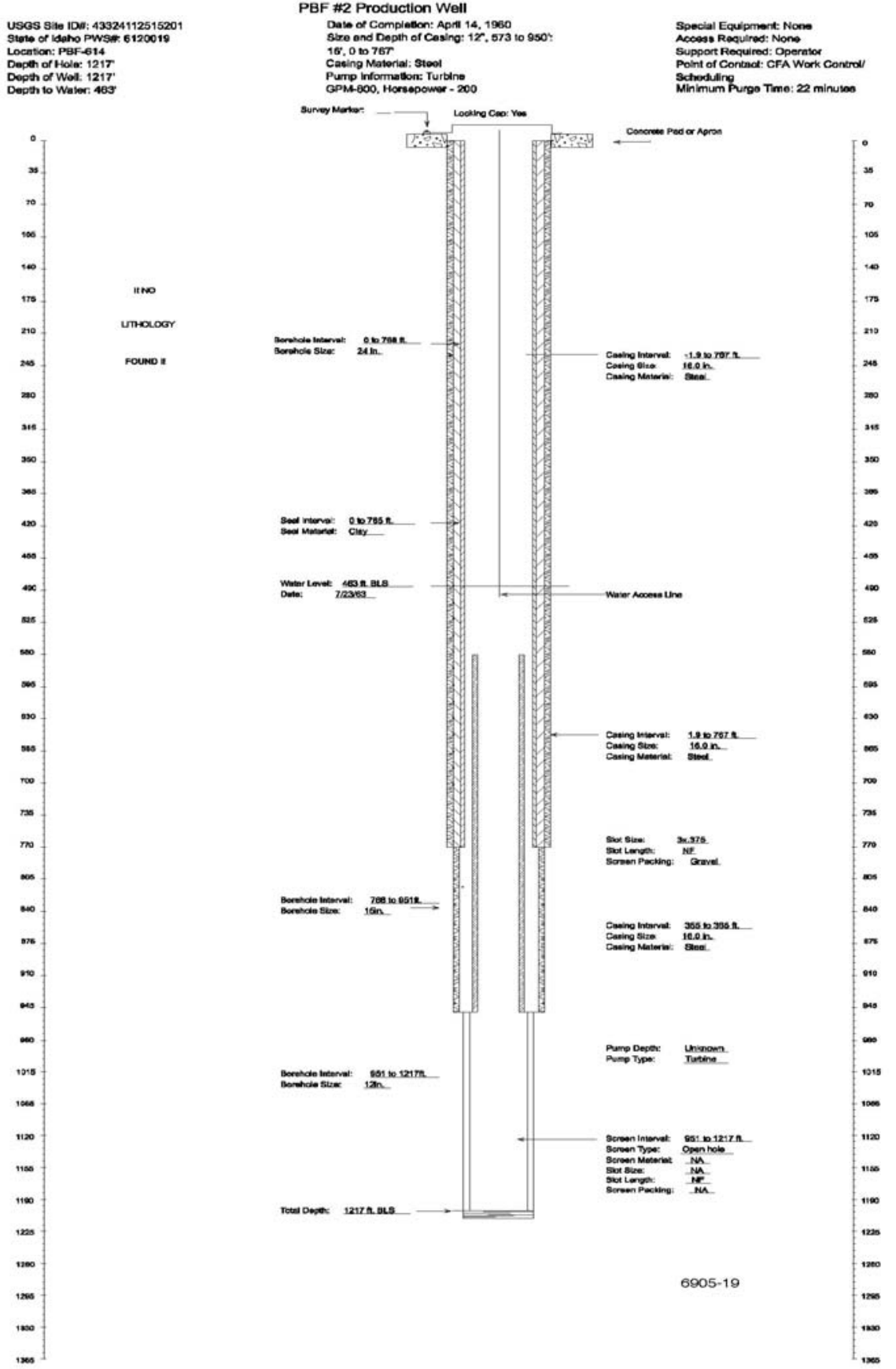

C-15 


\section{RWMC Potable Water Well}
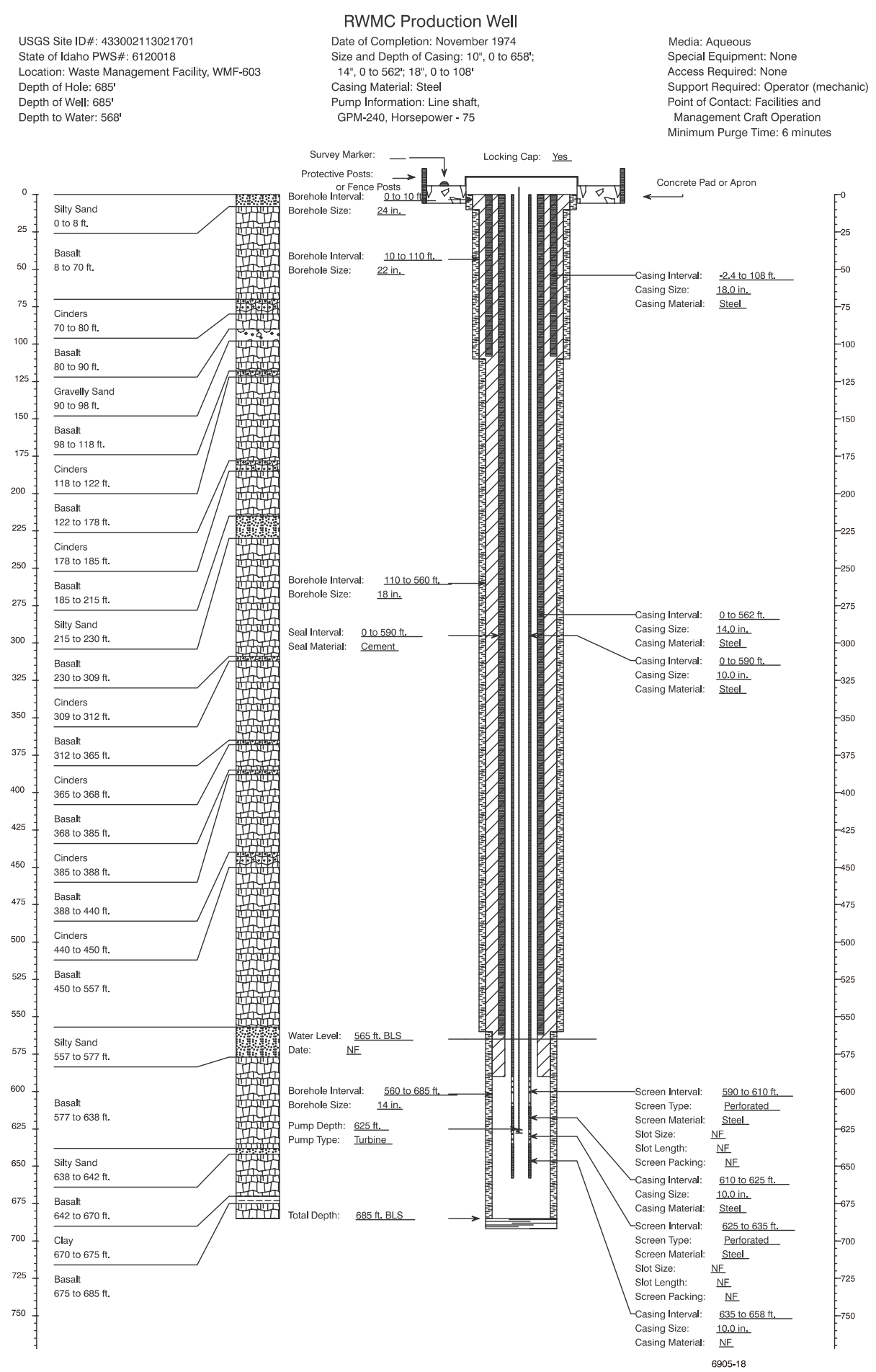

Survey Marker:
Protective Posts:
orcehole Intence Posts

Minimum Purge Time: 6 minutes 


\section{TRA \#1 Potable Water Well}
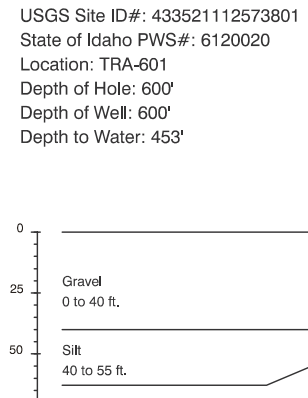

Basalt
55 to $75 \mathrm{ft}$

No Sample

75 to $90 \mathrm{ft}$.

$\begin{array}{ll}125 & \text { Basalt } \\ 90 \text { to } 152 \mathrm{ft}\end{array}$

150

Sand and Gravel

152 to $170 \mathrm{ft}$

$$
\text { Cinders }
$$

$$
\begin{aligned}
& \text { Cinders } \\
& 170 \text { to } 188 \mathrm{ft} \\
& \hline
\end{aligned}
$$

225

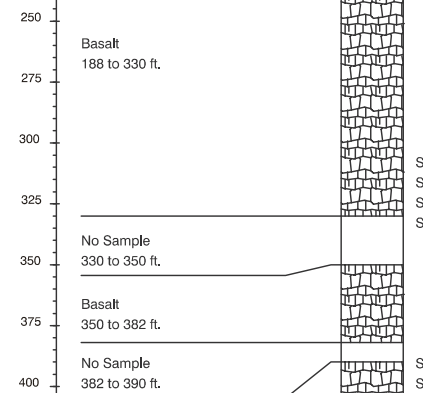

400 -

425

450

475

500

500

525 No Sample

550

575

Basal

570 to 595 ti

No Sample
595 to $600 \mathrm{ft}$

${ }^{625}=$

650

90 to $435 \mathrm{ft}$.

No Sample

435 to $450 \mathrm{ft}$

50 to $480 \mathrm{ft}$.
TRA \#1 Production Well

Date of Completion: February 1, 1950 Size and Depth of Casing: $18^{\prime \prime}, 0$ to $600^{\circ}$ Casing Material: Wrought iron

Pump Information: Line shaft,

GPM-3200, Horsepower - 700 Media: Aqueous

\section{Survey Marker:}

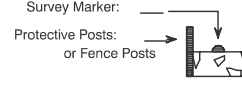
Seal Materi: 0 to $61 \mathrm{ft}$.

Seal Interval: $\quad \underline{61 \text { to } 68 \mathrm{ft} .}$ Seal Material: Concrete Seal Interval: 68 to 70

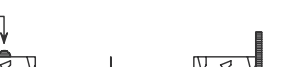

Concrete Pad or Apron

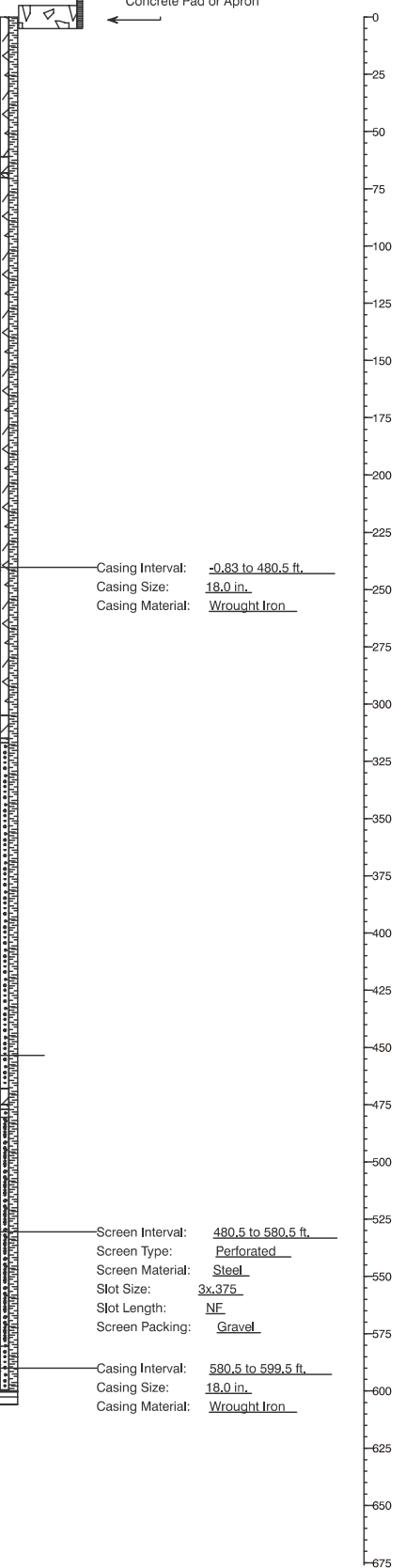

Special Equipment: Hearing protection Access Required: None

Support Required: Operator

Point of Contact: Utility Operators

Minimum Purge Time: 2 minutes

Seal Interval:

305 to $315 \mathrm{ft}$

Seal Interval: 315 to 317

Seal Material: Soil

Seal Interval: $\quad \underline{70}$ to $305 \mathrm{ft}$.

Seal Material: Native Fill

Borehole Size: $\quad \underline{20 \text { in. }}$

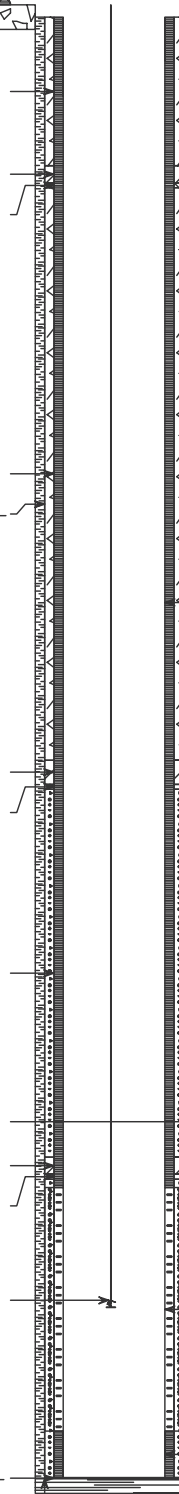




\section{TRA \#3 Potable Water Well}

USGS Site ID\#: 433522112573501
State of Idaho PWS\#: 6120020
Location: TRA-650
Depth of Hole: 602'
Depth of Well: 602 '
Depth to Water: 456
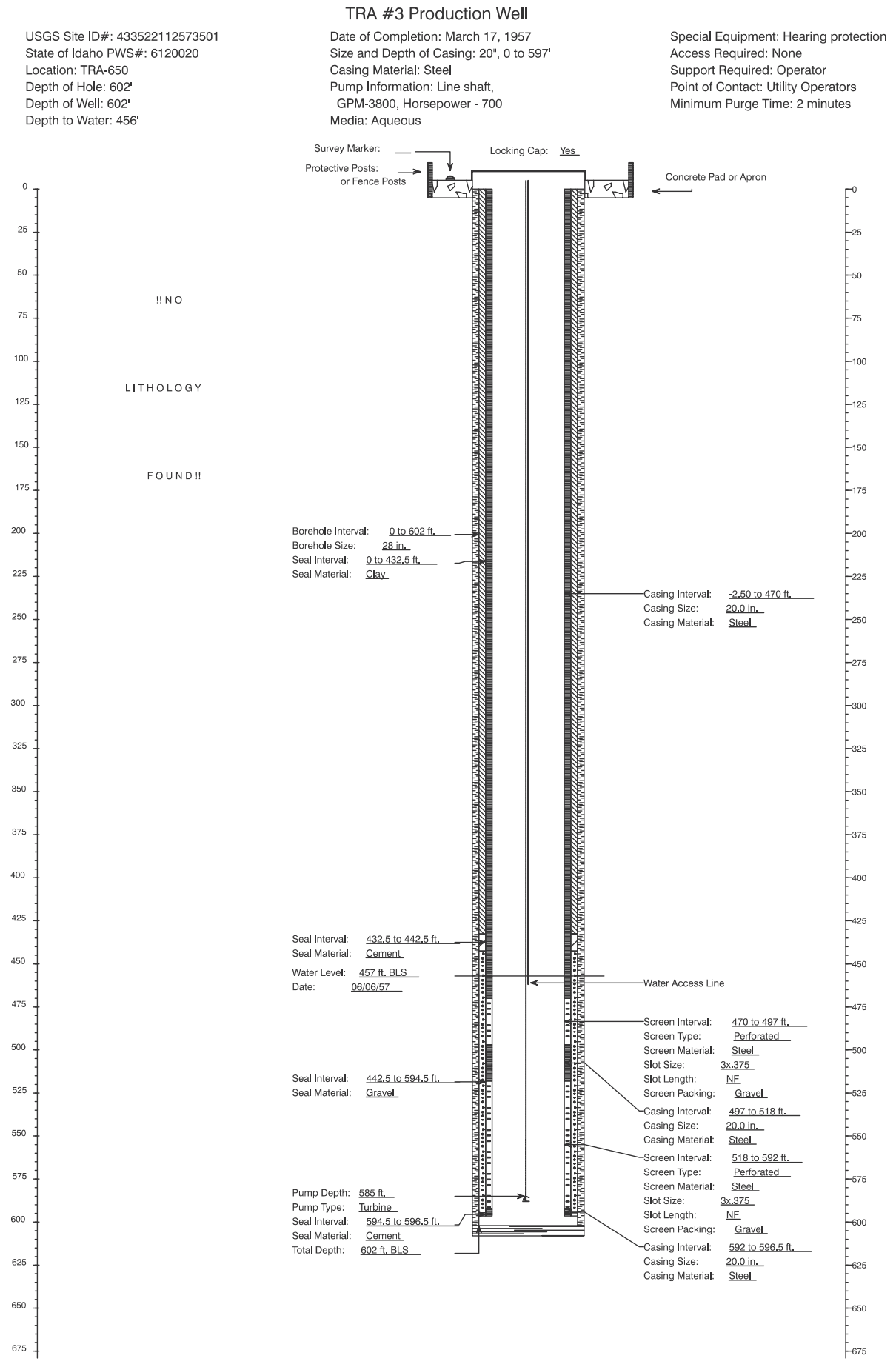

6905-14 
TRA \#4 Potable Water Well

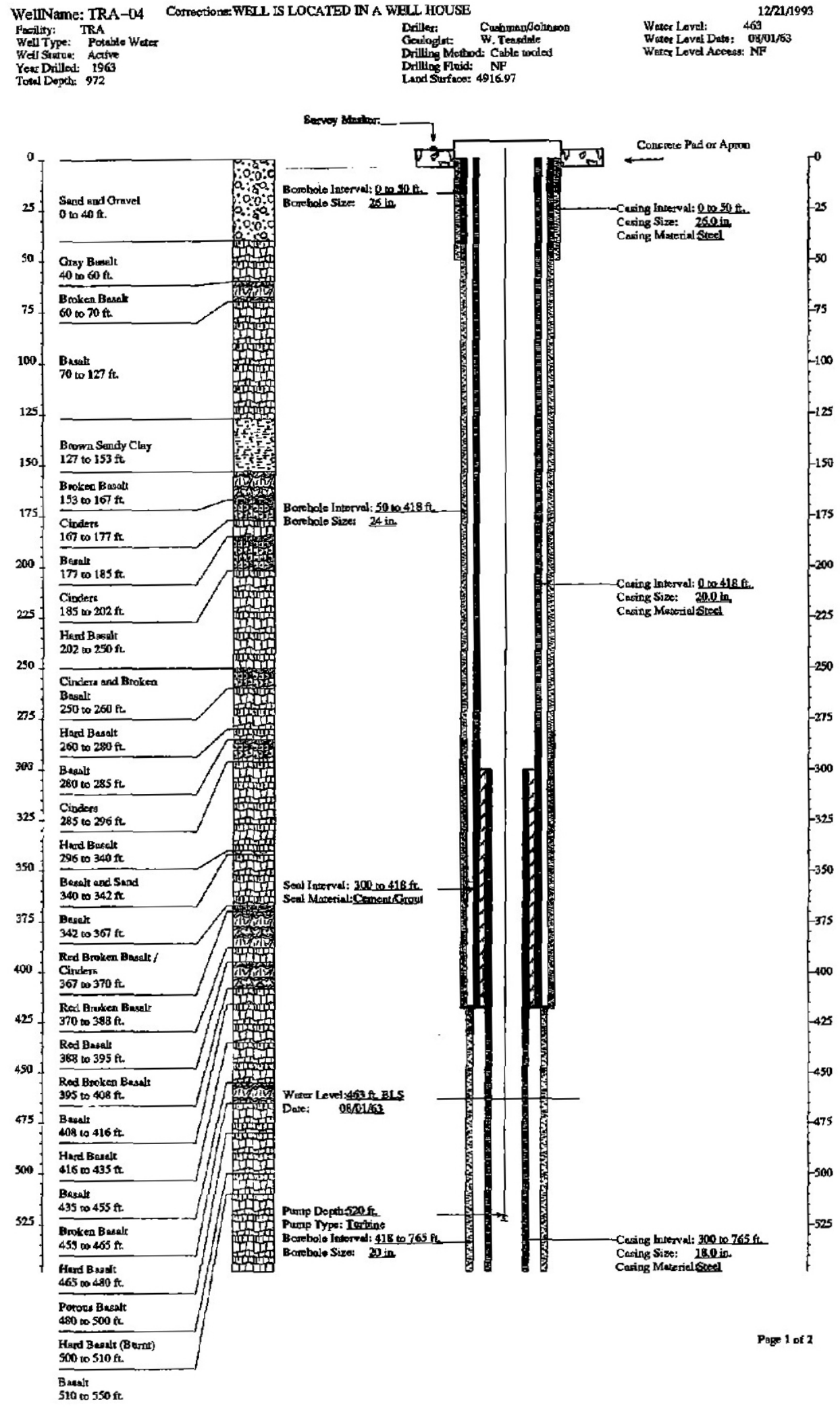


TRA \#4 Potable Water Well (continued)

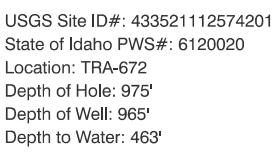

USGS Site ID\#: 433521112574201 State of Idaho PWS\#: 6120020 Location: TRA-672 Depth of Hole: $975^{\prime}$ Depth of Well: $965^{\prime}$ Depth to Water: 463

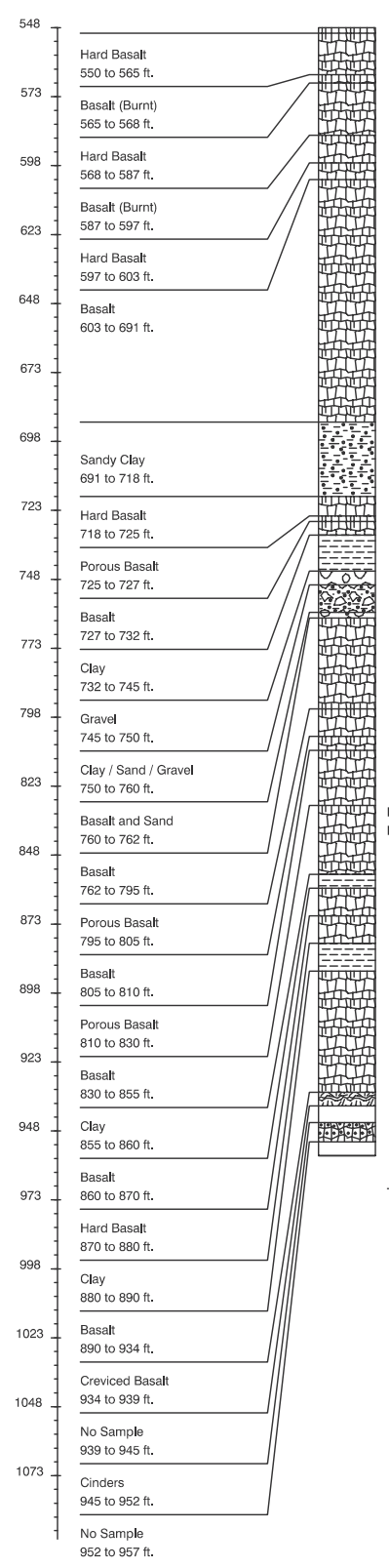

TRA \#4 Production Well

Date of Completion: July 25, 1963

Size and Depth of Casing: 16", 705 to 970 ; $\quad$ Special Equipment: Hearing protection $18^{\prime \prime}, 300$ to $765^{\prime} ; 20^{\prime \prime}, 0$ to $418^{\prime} ; 26^{\prime \prime}, 0$ to $50^{\prime}$ Casing Material: Steel

Pump Information: Line shaft,

GPM-2000, Horsepower - 350

Access Required: None

Support Required: Operator

Point of Contact: Utility Operators

Minimum Purge Time: 9 minutes

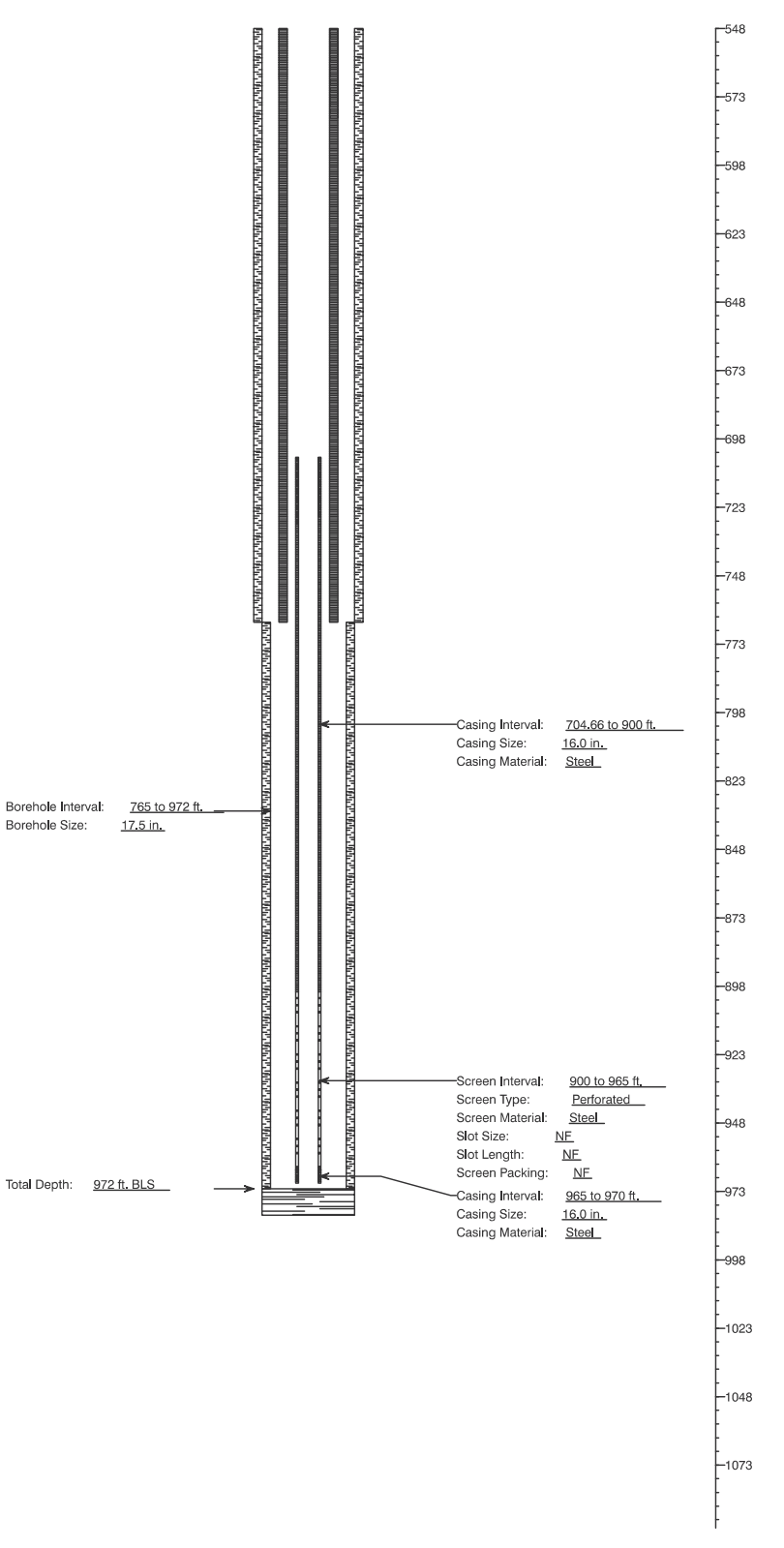

Page 2 of 2

6905-15 


\section{TSF \#1 Potable Water Well}

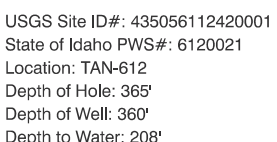

USGS Site ID\#: 435056112420001 State of Idaho PWS\#: 612002

Location: TAN-612

Depth of Hole: 365

Depth of Well: $360^{\prime}$

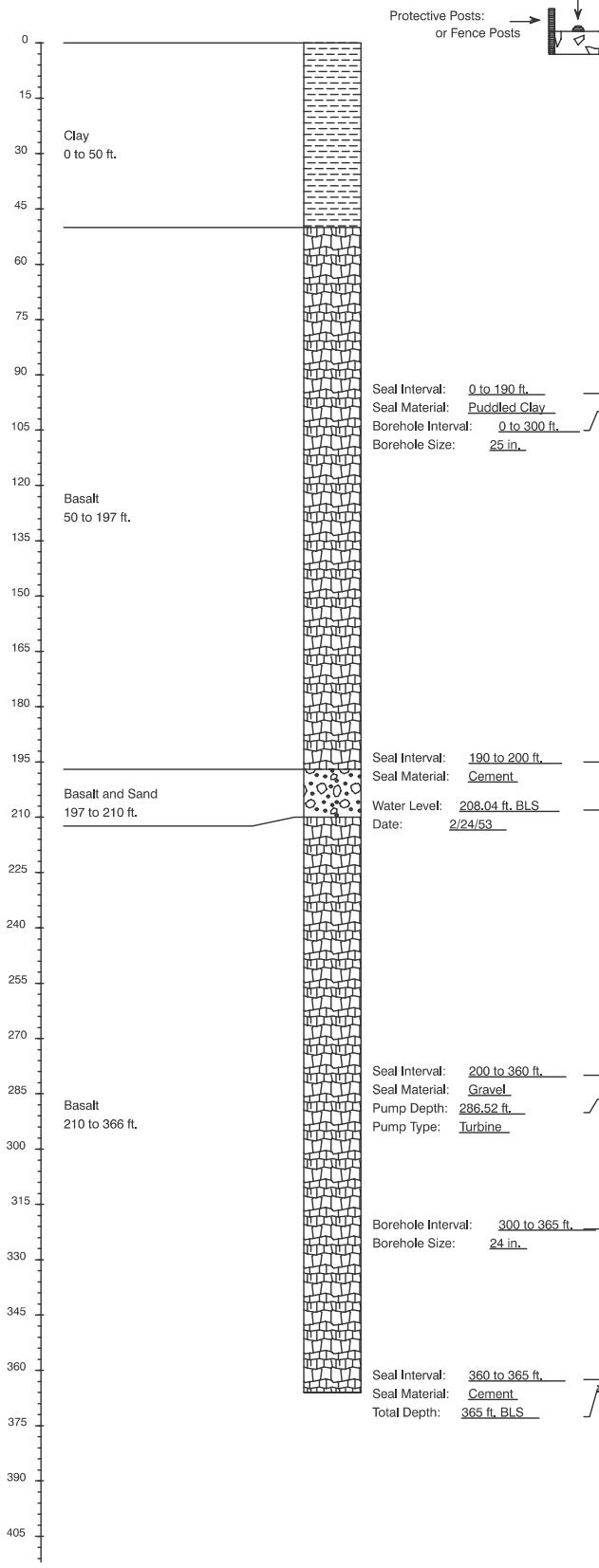

TSF \#1 Production Well

Date of Completion: January 26, 1953 Size and Depth of Casing: 16", 0 to 365 Casing Material: Steel Pump Information: Line shaft, GPM-1000, Horsepower - 80

Media: Aqueous

Special Equipment: None

Access Required: None

Support Required: Operator

Minimum Purge Time: 5 minutes 


\title{
TSF \#2 Potable Water Well
}

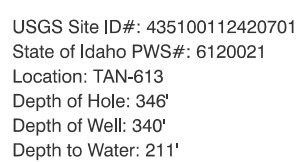

USGS Site ID\#: 435100112420701 State of Idaho PWS\#: 6120021 Location: TAN-613

Depth of Hole: $346^{\prime}$

Depth of Well: 340'

Depth to Water: 211'

\author{
TSF \#2 Production Well \\ Date of Completion: August 29, 1953 \\ Size and Depth of Casing: 16", 0 to 34 \\ Casing Material: Steel \\ Pump Information: Line shaft, \\ GPM-1000, Horsepower - 80 \\ Media: Aqueous
}

Special Equipment: None

Access Required: None

Support Required: Operator

Pint of Contact: (TAN) Utility Operators

Minimum Purge Time: 4 minutes

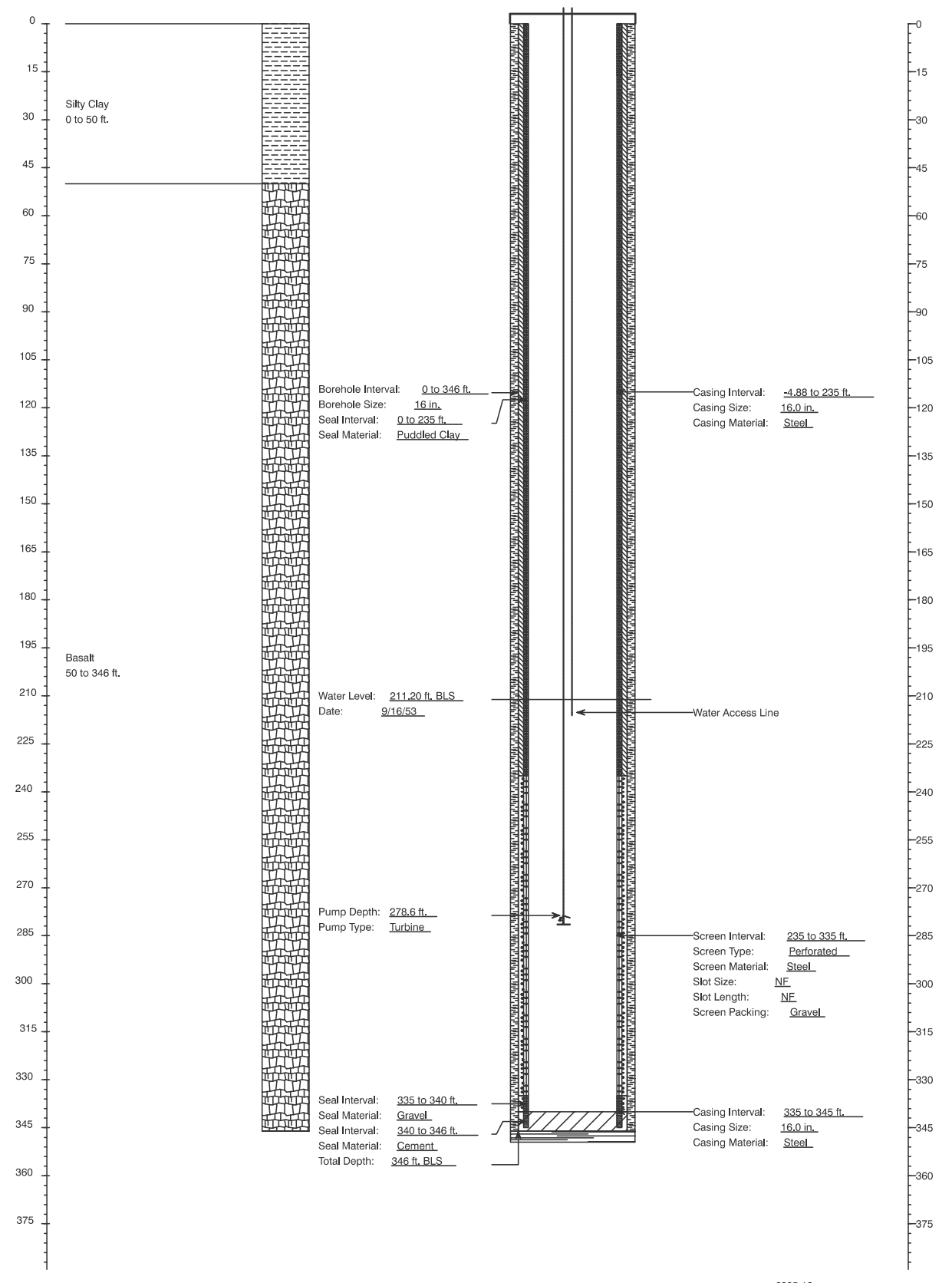

6905-12 
SPERT \#1 Potable Water Well
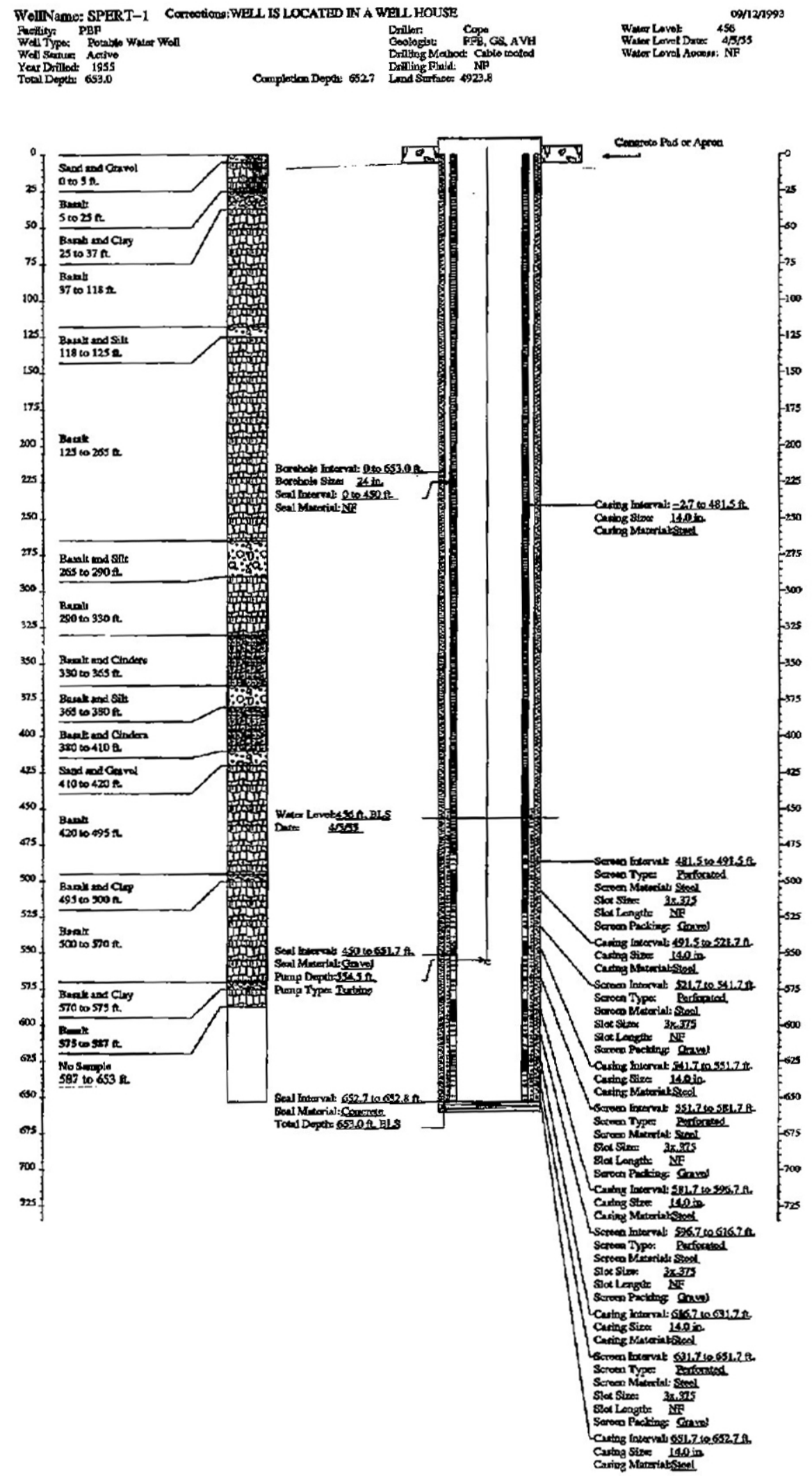


\section{USGS \#121 Potable Water Well}

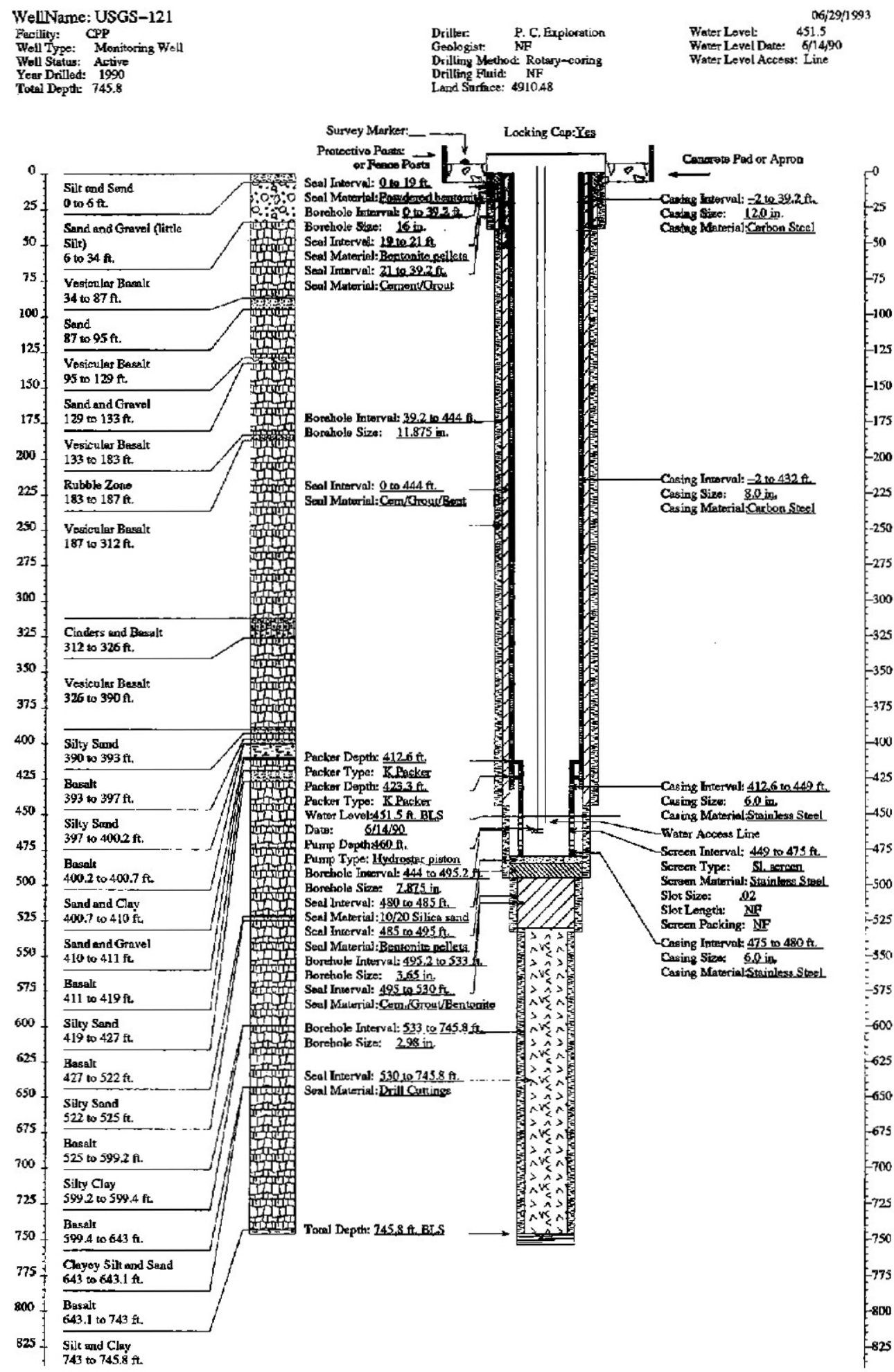




\section{APPENDIX D}

CONTAMINANTS OF INTEREST DETECTED IN INEEL DRINKING WATER SAMPLES FOR FY 1997-FY 2001 



\section{APPENDIX D \\ CONTAMINANTS OF INTEREST DETECTED IN INEEL DRINKING WATER SAMPLES FOR FY 1997-FY 2001}

Table D-1. 1997 Drinking water parameters of interest.

\begin{tabular}{|c|c|c|c|}
\hline Location & Parameter & Average Results ${ }^{\mathrm{a}}$ & MCL \\
\hline RWMC Distribution System & Carbon tetrachloride & $2.64 \mu \mathrm{g} / \mathrm{L}$ & $5.0 \mu \mathrm{g} / \mathrm{L}$ \\
\hline RWMC Well & Carbon tetrachloride & $4.23 \mu \mathrm{g} / \mathrm{L}$ & $N / A^{c}$ \\
\hline RWMC Distribution System & Trichloroethylene & $1.38 \mu \mathrm{g} / \mathrm{L}$ & $5.0 \mu \mathrm{g} / \mathrm{L}$ \\
\hline RWMC Well & Trichloroethylene & $2.08 \mu \mathrm{g} / \mathrm{L}$ & N/A \\
\hline TAN/TSF Distribution System & Trichloroethylene & $0.84 \mu \mathrm{g} / \mathrm{L}$ & $5.0 \mu \mathrm{g} / \mathrm{L}$ \\
\hline TAN/TSF Well \#1 & Trichloroethylene & $6.10 \mu \mathrm{g} / \mathrm{L}^{\mathrm{d}}$ & N/A \\
\hline TAN/TSF Well \#2 & Trichloroethylene & $2.85 \mu \mathrm{g} / \mathrm{L}$ & N/A \\
\hline CFA Distribution System & Tritium & $12,550 \pm 751 \mathrm{pCi} / \mathrm{L}$ & $20,000 \mathrm{pCi} / \mathrm{L}$ \\
\hline CFA Well \#1 & Tritium & $13,093 \pm 870 \mathrm{pCi} / \mathrm{L}$ & N/A \\
\hline CFA Well \#2 & Tritium & $11,774 \pm 929 \mathrm{pCi} / \mathrm{L}^{\mathrm{e}}$ & N/A \\
\hline \multicolumn{4}{|c|}{$\begin{array}{l}\text { b. The distribution system is the point of compliance. However, the Drinking Water Program also samples the individual wells and } \\
\text { tracks their concentrations. }\end{array}$} \\
\hline $\begin{array}{l}\text { c. N/A-not applicable since the wells } \\
\text { d. This average is not a four-quarter a } \\
\text { e. This average is not a four-quarter av } \\
\text { was out of service during the fourth qu }\end{array}$ & $\begin{array}{l}\text { ot the point of compliance. } \\
\text {; it is based on } 2 \text { samples } t \\
\text { r. it is based on } 3 \text { samples. }\end{array}$ & $\begin{array}{l}\text { urveillance purposes. } \\
\text { nstruction activities (repla }\end{array}$ & the pump), the well \\
\hline
\end{tabular}


Table D-2. 1998 drinking water parameters of interest.

\begin{tabular}{|c|c|c|c|}
\hline Location & Parameter & Average Results ${ }^{\mathrm{a}}$ & $\mathrm{MCL}^{\mathrm{b}}$ \\
\hline RWMC Distribution System & Carbon tetrachloride & $2.80 \mu \mathrm{g} / \mathrm{L}$ & $5.0 \mu \mathrm{g} / \mathrm{L}$ \\
\hline RWMC Well & Carbon tetrachloride & $4.75 \mu \mathrm{g} / \mathrm{L}$ & $\mathrm{N} / \mathrm{A}^{\mathrm{c}}$ \\
\hline RWMC Distribution System & Trichloroethylene & $1.45 \mu \mathrm{g} / \mathrm{L}$ & $5.0 \mu \mathrm{g} / \mathrm{L}$ \\
\hline RWMC Well & Trichloroethylene & $2.20 \mu \mathrm{g} / \mathrm{L}$ & $\mathrm{N} / \mathrm{A}$ \\
\hline TAN/TSF Distribution System & Trichloroethylene & $1.42 \mu \mathrm{g} / \mathrm{L}$ & $5.0 \mu \mathrm{g} / \mathrm{L}$ \\
\hline TAN/TSF Well \#1 & Trichloroethylene & $4.60 \mu \mathrm{g} / \mathrm{L}^{\mathrm{d}}$ & $\mathrm{N} / \mathrm{A}$ \\
\hline TAN/TSF Well \#2 & Trichloroethylene & $2.60 \mu \mathrm{g} / \mathrm{L}$ & N/A \\
\hline CFA Distribution System & Tritium & $11,050 \pm 861 \mathrm{pCi} / \mathrm{L}$ & $20,000 \mathrm{pCi} / \mathrm{L}$ \\
\hline CFA Well \#1 & Tritium & $12,317 \pm 953 \mathrm{pCi} / \mathrm{L}^{\mathrm{e}}$ & N/A \\
\hline CFA Well \#2 & Tritium & $10,705 \pm 716 \mathrm{pCi} / \mathrm{L}$ & N/A \\
\hline \multicolumn{4}{|c|}{ a. Radiological averages are weighted averages. } \\
\hline \multicolumn{4}{|c|}{$\begin{array}{l}\text { b. The distribution system is the point of compliance. However, the Drinking Water Program also samples the individual wells and } \\
\text { tracks their concentrations. }\end{array}$} \\
\hline \multicolumn{4}{|c|}{ c. N/A-not applicable since the wells are not the point of compliance. } \\
\hline \multicolumn{4}{|c|}{ d. This average is not a four-quarter average; it is based on 1 sample taken for surveillance purposes. } \\
\hline \multicolumn{4}{|c|}{$\begin{array}{l}\text { e. This average is not a four-quarter average; it is based on } 3 \text { samples. Due to construction activities, the well was out of service } \\
\text { during the third quarter. }\end{array}$} \\
\hline
\end{tabular}


Table D-3. 1999 drinking water parameters of interest.

\begin{tabular}{|c|c|c|c|}
\hline Location & Parameter & Average Results ${ }^{\mathrm{a}}$ & $\mathrm{MCL}^{\mathrm{b}}$ \\
\hline RWMC Distribution System & Carbon Tetrachloride & $2.70 \mu \mathrm{g} / \mathrm{L}$ & $5.0 \mu \mathrm{g} / \mathrm{L}$ \\
\hline RWMC Well & Carbon Tetrachloride & $4.65 \mu \mathrm{g} / \mathrm{L}$ & $\mathrm{N} / \mathrm{A}^{\mathrm{c}}$ \\
\hline RWMC Distribution System & Trichloroethylene & $1.35 \mu \mathrm{g} / \mathrm{L}$ & $5.0 \mu \mathrm{g} / \mathrm{L}$ \\
\hline RWMC Well & Trichloroethylene & $1.98 \mu \mathrm{g} / \mathrm{L}$ & $\mathrm{N} / \mathrm{A}$ \\
\hline TAN/TSF Distribution System & Trichloroethylene & $1.20 \mu \mathrm{g} / \mathrm{L}$ & $5.0 \mu \mathrm{g} / \mathrm{L}$ \\
\hline TAN/TSF Well \#1 & Trichloroethylene & $4.35 \mu \mathrm{g} / \mathrm{L}^{\mathrm{d}}$ & $\mathrm{N} / \mathrm{A}$ \\
\hline TAN/TSF Well \#2 & Trichloroethylene & $2.00 \mu \mathrm{g} / \mathrm{L}$ & $\mathrm{N} / \mathrm{A}$ \\
\hline CFA Distribution System & Tritium & $12,786 \pm 1,003 \mathrm{pCi} / \mathrm{L}$ & $20,000 \mathrm{pCi} / \mathrm{L}$ \\
\hline CFA Well \#1 & Tritium & $13,391 \pm 1,047 \mathrm{pCi} / \mathrm{L}$ & $\mathrm{N} / \mathrm{A}$ \\
\hline CFA Well \#2 & Tritium & $10,910 \pm 1,002 \mathrm{pCi} / \mathrm{L}^{\mathrm{e}}$ & N/A \\
\hline NRF Distribution System & Total coliform & Present $^{\mathrm{f}}$ & Absence \\
\hline INTEC Distribution & Total coliform & Present $^{\mathrm{f}}$ & Absence \\
\hline TRA Distribution & Total coliform & Present $^{\mathrm{f}}$ & Absence \\
\hline \multicolumn{4}{|c|}{ a. Radiological averages are weighted averages. } \\
\hline \multicolumn{4}{|c|}{$\begin{array}{l}\text { b. The distribution system is the point of compliance. However, the Drinking Water Program also samples the individual wells and } \\
\text { tracks their concentrations. }\end{array}$} \\
\hline \multicolumn{4}{|c|}{ c. N/A-not applicable since the wells are not the point of compliance. } \\
\hline \multicolumn{4}{|c|}{ d. This average is not a four-quarter average; it is based on 2 samples taken in October and November. } \\
\hline \multicolumn{4}{|c|}{$\begin{array}{l}\text { e. This average is not a four-quarter average; it is based on } 3 \text { samples. Due to construction activities, the well was out of service during } \\
\text { the third quarter. }\end{array}$} \\
\hline \multicolumn{4}{|c|}{$\begin{array}{l}\text { f. Total coliform bacteria was detected in the INTEC distribution system in May, in the TRA distribution system in August, and in the } \\
\text { NRF distribution system in October. }\end{array}$} \\
\hline
\end{tabular}


Table D-4. 2000 drinking water parameters of interest.

\begin{tabular}{|c|c|c|c|}
\hline Location & Parameter & Average Results & $\mathrm{MCL}^{\mathrm{b}}$ \\
\hline RWMC Distribution System & Carbon tetrachloride & $2.33 \mu \mathrm{g} / \mathrm{L}$ & $5.0 \mu \mathrm{g} / \mathrm{L}$ \\
\hline RWMC Well & Carbon tetrachloride & $4.33 \mu \mathrm{g} / \mathrm{L}$ & $\mathrm{N} / \mathrm{A}^{\mathrm{c}}$ \\
\hline RWMC Distribution System & Trichloroethylene & $1.27 \mu \mathrm{g} / \mathrm{L}$ & $5.0 \mu \mathrm{g} / \mathrm{L}$ \\
\hline RWMC Well & Trichloroethylene & $1.87 \mu \mathrm{g} / \mathrm{L}$ & $\mathrm{N} / \mathrm{A}$ \\
\hline TAN/TSF Distribution System & Trichloroethylene & $0.97 \mu \mathrm{g} / \mathrm{L}^{\mathrm{d}}$ & $5.0 \mu \mathrm{g} / \mathrm{L}$ \\
\hline TAN/TSF Well \#1 & Trichloroethylene & $3.65 \mu \mathrm{g} / \mathrm{L}^{\mathrm{e}}$ & $\mathrm{N} / \mathrm{A}$ \\
\hline TAN/TSF Distribution System & Trichloroethylene $\left(\mathrm{tic}^{\mathrm{f}}\right)$ & $1.00 \mu \mathrm{g} / \mathrm{L}$ & $\mathrm{N} / \mathrm{A}$ \\
\hline CFA Distribution System & Tritium & $11,126 \pm 812 \mathrm{pCi} / \mathrm{L}$ & $20,000 \mathrm{pCi} / \mathrm{L}$ \\
\hline CFA Well \#1 & Tritium & $11,673 \pm 849 \mathrm{pCi} / \mathrm{L}^{\mathrm{g}}$ & N/A \\
\hline CFA Well \#2 & Tritium & $10,028 \pm 883 \mathrm{pCi} / \mathrm{L}$ & N/A \\
\hline \multicolumn{4}{|c|}{ a. Radiological averages are weighted averages. } \\
\hline \multicolumn{4}{|c|}{$\begin{array}{l}\text { b. The distribution system is the point of compliance. However, the Drinking Water Program also samples the individual wells and } \\
\text { tracks their concentrations. }\end{array}$} \\
\hline \multicolumn{4}{|c|}{ c. N/A-not applicable since the wells are not the point of compliance. } \\
\hline \multicolumn{4}{|c|}{$\begin{array}{l}\text { d. This average is not a four-quarter average; it is based on } 3 \text { samples. No volatile organic samples were collected in the third quarter of } \\
2000 \text { because no laboratory contract was in place. }\end{array}$} \\
\hline \multicolumn{4}{|c|}{ e. This average is not a four-quarter average; it is based on 2 samples taken from surveillance purposes. } \\
\hline \multicolumn{4}{|l|}{ f. tic-tentatively identified compound } \\
\hline \multicolumn{4}{|c|}{$\begin{array}{l}\text { g. This average is not a four-quarter average; it is based on } 3 \text { samples. No second quarter results were available for this location } \\
\text { because of maintenance and repair. }\end{array}$} \\
\hline
\end{tabular}


Table D-5. 2001 drinking water parameters of interest.

\begin{tabular}{|c|c|c|c|}
\hline Location & Parameter & Average Results ${ }^{\mathrm{a}}$ & $\mathrm{MCL}^{\mathrm{b}}$ \\
\hline RWMC Distribution System & Carbon Tetrachloride & $2.40 \mu \mathrm{g} / \mathrm{L}$ & $5.0 \mu \mathrm{g} / \mathrm{L}$ \\
\hline RWMC Well & Carbon Tetrachloride & $3.68 \mu \mathrm{g} / \mathrm{L}$ & $N / A^{c}$ \\
\hline RWMC Distribution System & Trichloroethylene & $1.23 \mu \mathrm{g} / \mathrm{L}$ & $5.0 \mu \mathrm{g} / \mathrm{L}$ \\
\hline RWMC Well & Trichloroethylene & $1.63 \mu \mathrm{g} / \mathrm{L}$ & $\mathrm{N} / \mathrm{A}$ \\
\hline TAN/TSF Distribution System & Trichloroethylene & $1.30 \mu \mathrm{g} / \mathrm{L}$ & $5.0 \mu \mathrm{g} / \mathrm{L}$ \\
\hline TAN/TSF Well \#1 & Trichloroethylene & $3.20 \mu \mathrm{g} / \mathrm{L}^{\mathrm{d}}$ & N/A \\
\hline TAN/TSF Well \#2 & Trichloroethylene & $3.00 \mu \mathrm{g} / \mathrm{L}^{\mathrm{d}}$ & N/A \\
\hline CFA Distribution System & Tritium & $9,719 \pm 643 \mathrm{pCi} / \mathrm{L}$ & $20,000 \mathrm{pCi} / \mathrm{L}$ \\
\hline CFA Well \#1 & Tritium & $10,597 \pm 696 \mathrm{pCi} / \mathrm{L}$ & $\mathrm{N} / \mathrm{A}$ \\
\hline CFA Well \#2 & Tritium & $9,844 \pm 652 \mathrm{pCi} / \mathrm{L}$ & N/A \\
\hline RWMC Distribution & Total Coliform & Present $^{\mathrm{e}}$ & Absence \\
\hline \multicolumn{4}{|c|}{ a. Radiological averages are weighted averages. } \\
\hline \multicolumn{4}{|c|}{$\begin{array}{l}\text { b. The distribution system is the point of compliance. However, the Drinking Water Program also samples the individual wells and } \\
\text { tracks their concentrations. }\end{array}$} \\
\hline \multicolumn{4}{|c|}{ c. N/A-not applicable since the wells are not the point of compliance. } \\
\hline \multicolumn{4}{|c|}{ d. This average is not a four-quarter average; it is based on 2 samples taken from surveillance purposes. } \\
\hline
\end{tabular}




\section{Disclaimer}

This software is intended to assist users in identifying, locating, and understanding attributes associated with the Idaho National Engineering and Environmental Laboratory (INEEL) and its Source Water Assessment Program. It was produced using the best information that was readily available as of January 2003. Information provided was sufficient for meeting the author's needs for this project; however, it may be incomplete or not current in meeting the needs of others. Therefore, the user must verify any essential information obtained from this software. Neither the software developer, information contributors, nor INEEL personnel, who sponsored its development, take any responsibility for the accuracy or completeness of information provided by this software. 


\section{CONTENTS}

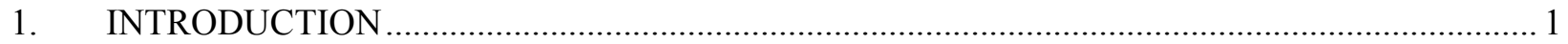

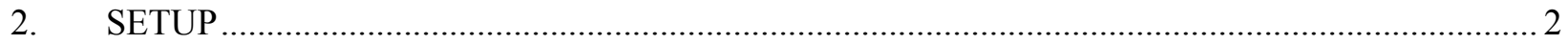

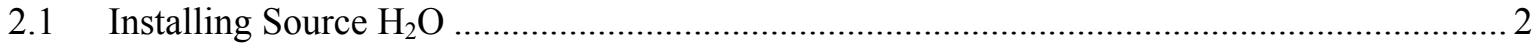

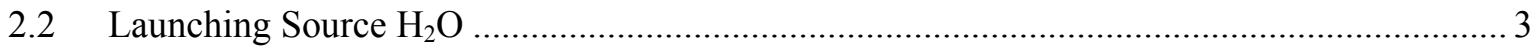

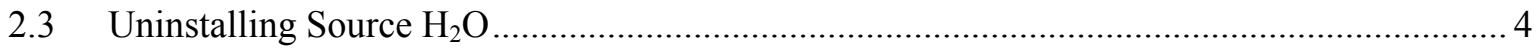

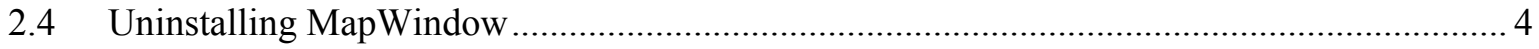

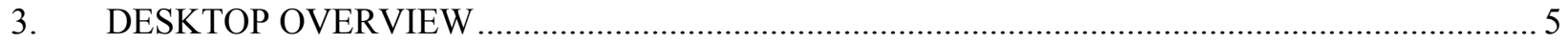

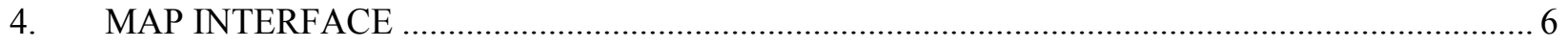

$4.1 \quad$ Legend

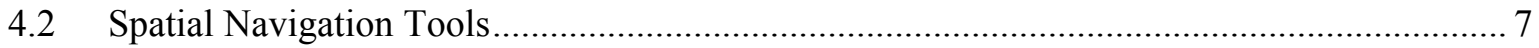

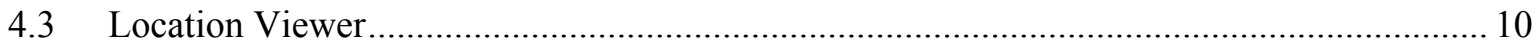

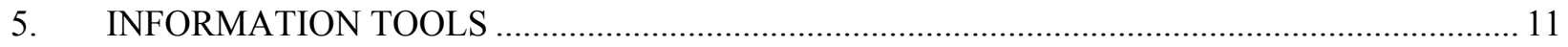

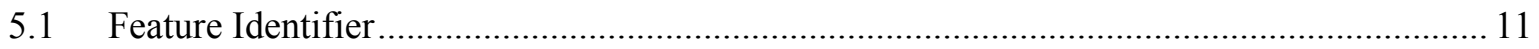

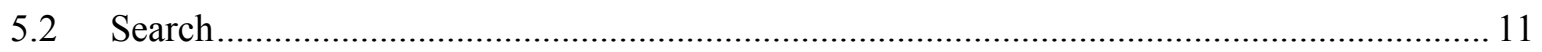

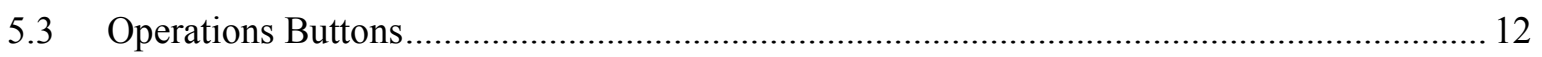

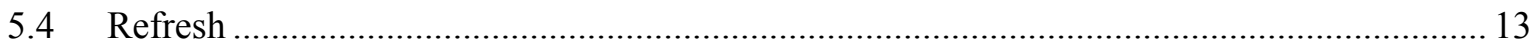

\section{FIGURES}

1. Example of using the Run... option under the Start menu for installing Source $\mathrm{H}_{2} \mathrm{O} \ldots \ldots \ldots \ldots \ldots \ldots \ldots . . .2$

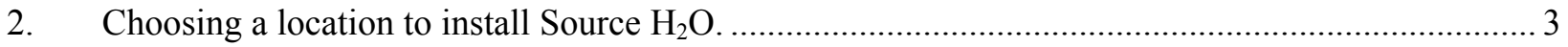

3. Specifying where shortcuts will be located once installation is complete..................................... 3

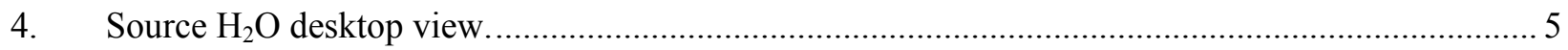

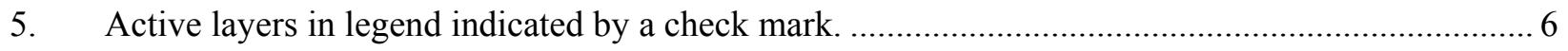

6. Example of moving the position of the Big Lost INTEC 7 mi Points data layer in the legend.......... 6

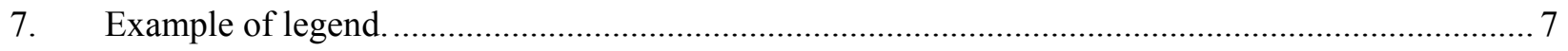


8. Spatial navigation toolbar.

9. Example of zooming in to an area of interest by left clicking and drawing a rectangle around the desired area

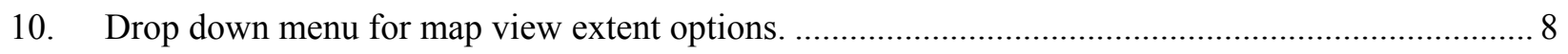

11. Example of Potable Water Wells as the selected data layer.................................................... 9

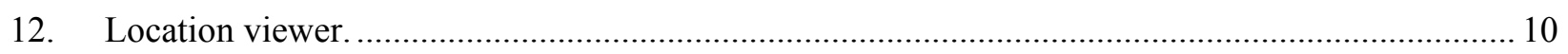

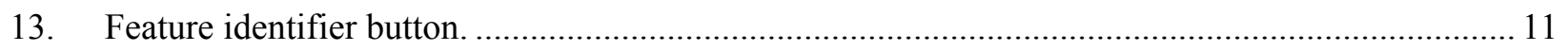

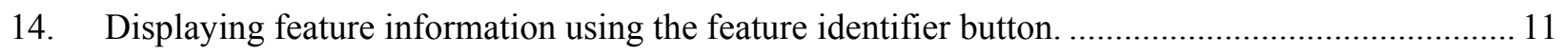

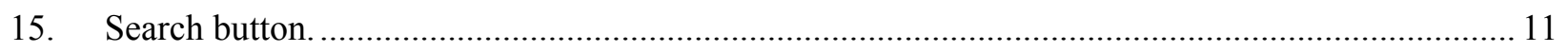

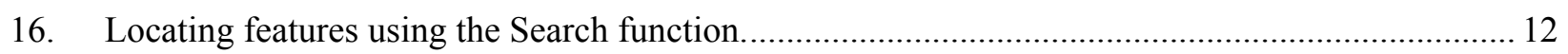

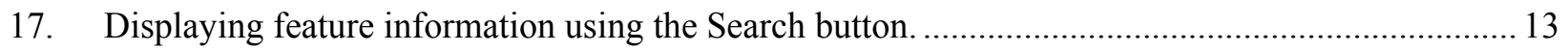




\section{Source $\mathrm{H}_{2} \mathrm{O}$ BETA Version 1.0 User's Guide \\ 1. INTRODUCTION}

The Source $\mathrm{H}_{2} \mathrm{O}$ application was developed as part of the INEEL's Source Water Assessment Program as a tool to clearly and efficiently present and describe the physical attributes associated with source water protection at the Idaho National Engineering and Environmental Laboratory. The Source $\mathrm{H}_{2} \mathrm{O}$ provides users a broad overview of the INEEL and insights into the physical setting, infrastructure, and activities that can affect the quality of the INEEL drinking water sources.

A Source $\mathrm{H}_{2} \mathrm{O}$ prototype was designed and developed at the INEEL using the spatial mapping/analysis platform, MapWindow. This platform was developed through a collaboration between the INEEL and Utah State University's Environmental Management Research Center as a Laboratory Directed Research and Development project in the Ecological and Cultural Resources Department (Integrated Watershed Management Tools; Ron Rope, and Jerry Sehlke). The internally developed platform was chosen because of its flexible user interface, the level of support associated with it due to close relationships with the developers at the Environmental Management Research Center, and the ease of developing added functionality.

The data layers included in this application were collected from existing sources within various departments at the INEEL.

This guide describes:

- Installation and uninstalling Source $\mathrm{H}_{2} \mathrm{O}$

- $\quad$ The map interface operations

- The functionality associated with the Source $\mathrm{H}_{2} \mathrm{O}$ application. 


\section{SETUP}

\subsection{Installing Source $\mathrm{H}_{2} \mathrm{O}$}

Important: Please shutdown all unnecessary running applications before running Source $\mathrm{H}_{2} \mathrm{O}$ setup.

If you have a previous version of Source $\mathrm{H}_{2} \mathrm{O}$ installed on your computer, uninstall both the old Source $\mathrm{H}_{2} \mathrm{O}$ application (Section 2.3) and MapWindow (Section 2.4) before installing this new version.

The Source $\mathrm{H}_{2} \mathrm{O}$ application is distributed on CD-ROM, and all components must be installed on the user's computer before accessing Source $\mathrm{H}_{2} \mathrm{O}$.

To initiate the setup:

Insert the Source $\mathrm{H}_{2} \mathrm{O}$ CD into CD-ROM drive, browse the CD-ROM drive from MS Explorer, and double click on Source H2O_Install.exe.

OR

Click the Start button on the desktop, click Run, and then type the drive letter assigned to the CD-ROM drive followed by Source H2O_Install.exe (Figure 1).

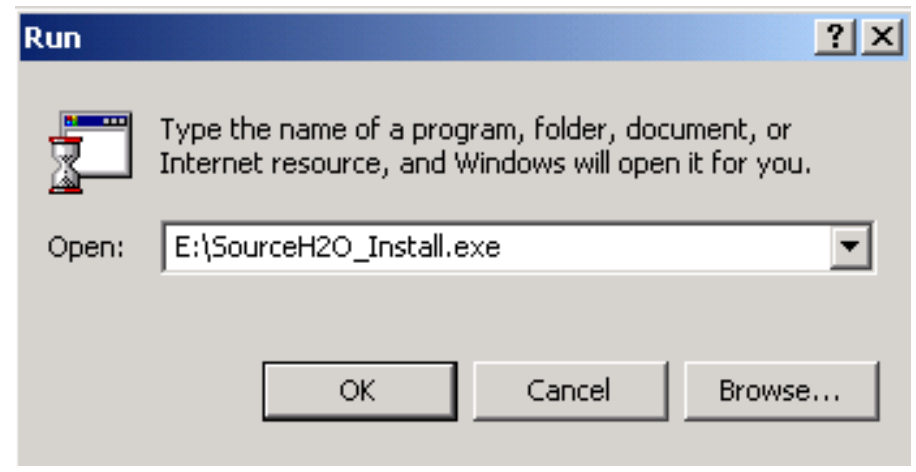

Figure 1. Example of using the Run... option under the Start menu for installing Source $\mathrm{H}_{2} \mathrm{O}$. 
The default installation folder for Source $\mathrm{H}_{2} \mathrm{O}$ is " $\mathrm{C}$ : Program Files $\backslash$ Source $\mathrm{H}_{2} \mathrm{O}$ ". You can change this default destination drive and folder. Ensure that the required memory is available before choosing an installation location. To change the destination drive and folder, select the Browse... button, and enter the desired default destination drive in the popup box (Figure 2).

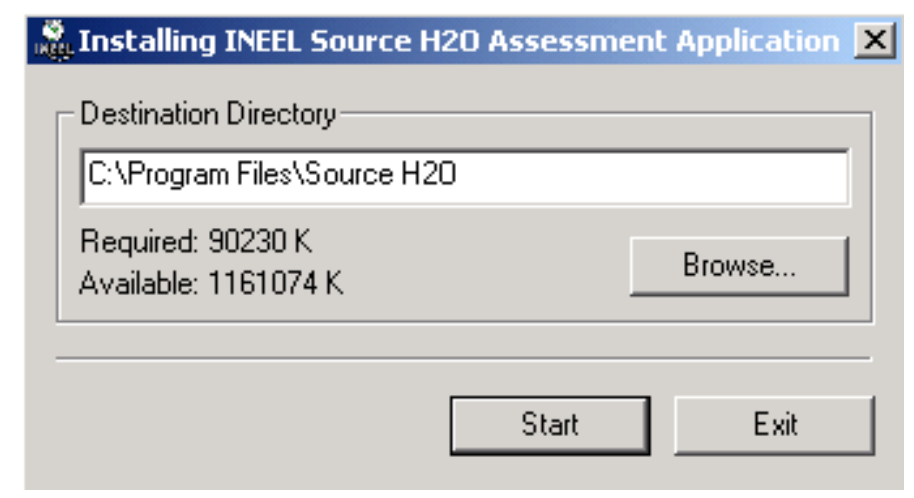

Figure 2. Choosing a location to install Source $\mathrm{H}_{2} \mathrm{O}$.

Source $\mathrm{H}_{2} \mathrm{O}$ requires the installation of MapWindow as its mapping interface. The setup for MapWindow will launch automatically at the end of the Source $\mathrm{H}_{2} \mathrm{O}$ setup. The onscreen dialog will guide you through this setup.

After MapWindow is installed, a window will pop up with two locations to create shortcuts for running and uninstalling Source $\mathrm{H}_{2} \mathrm{O}$ : "Create Shortcut(s) on Desktop" or "Create Shortcut(s) in Startup" (Figure 3). The default selection is both options. To keep the default or select/deselect either option, check or uncheck the related box to the left of the option.

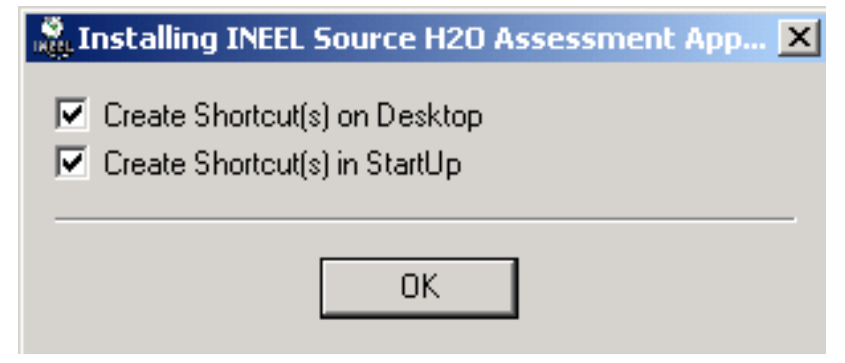

Figure 3. Specifying where shortcuts will be located once installation is complete.

\subsection{Launching Source $\mathrm{H}_{2} \mathrm{O}$}

If the "Create Shortcut(s) on Desktop" option was chosen during setup, a window will pop up with shortcuts for starting Source $\mathrm{H}_{2} \mathrm{O}$ or uninstalling the application. To move these shortcuts to the desktop, left click and drag them to the desired location. To begin running Source $\mathrm{H}_{2} \mathrm{O}$, double click on the Source $\mathrm{H}_{2} \mathrm{O}$ icon.

If the "Create Shortcut(s) in StartUp" option was chosen during setup, launch Source $\mathrm{H}_{2} \mathrm{O}$ by clicking on the Start button, going to Programs, then Source $\mathrm{H}_{2} \mathbf{O}$, and clicking on the Source $\mathrm{H}_{2} \mathrm{O}$ icon.

To run Source $\mathrm{H}_{2} \mathrm{O}$ the first time, restart your computer after setup.

If Source $\mathrm{H}_{2} \mathrm{O}$ did not install properly after the first installation, uninstall Source $\mathrm{H}_{2} \mathrm{O}$ as described in Section 2.3. Next, install Source $\mathrm{H}_{2} \mathrm{O}$ again. When asked whether to Modify, Repair, or Remove the MapWindow application, select Cancel. 


\subsection{Uninstalling Source $\mathrm{H}_{2} \mathrm{O}$}

There are three ways to uninstall Source $\mathrm{H}_{2} \mathrm{O}$ from your computer depending on the options you selected during setup:

- If the "Create Shortcut(s) on Desktop" option was chosen during setup and the "Uninstall" icon was placed on the desktop, double click the "Uninstall" icon to remove the application.

- If the "Create Shortcut(s) in StartUp" option was chosen during setup, click on the Start button, select Programs, then Source $\mathbf{H}_{2} \mathbf{O}$, and click on the "Uninstall" icon.

- If the "Uninstall" icon was not placed on the desktop or in the Start menu, locate the Uninstall.exe file in the Source $\mathrm{H}_{2} \mathrm{O}$ program folder. The location of this folder was determined by the user during installation. To locate the Source $\mathrm{H}_{2} \mathrm{O}$ folder, go to the Start menu, choose Find..., select Files or Folders...., and enter "Source $\mathrm{H}_{2} \mathrm{O}$ " for the search term.

\subsection{Uninstalling MapWindow}

To uninstall MapWindow, double click on the My Computer icon on the desktop, double click on Control Panel, double click on Add/Remove Programs, click the Install/Uninstall tab, scroll through the program list, select MapWindow, and, click the Add/Remove button.

If you uninstall Source $\mathrm{H}_{2} \mathrm{O}$ or MapWindow, you must reload the appropriate application by going through the steps described in Sections 2.1 and 2.2 before accessing them again. 


\section{DESKTOP OVERVIEW}

The Source $\mathrm{H}_{2} \mathrm{O}$ desktop view (Figure 4) consists of six areas:

- $\quad$ Menu Bar

- Toolbar

- $\quad$ Data Layer Menu

- $\quad$ Legend

- $\quad$ Location Viewer

- $\quad$ Map View.

These areas and their associated functions are described in detail in the following sections.

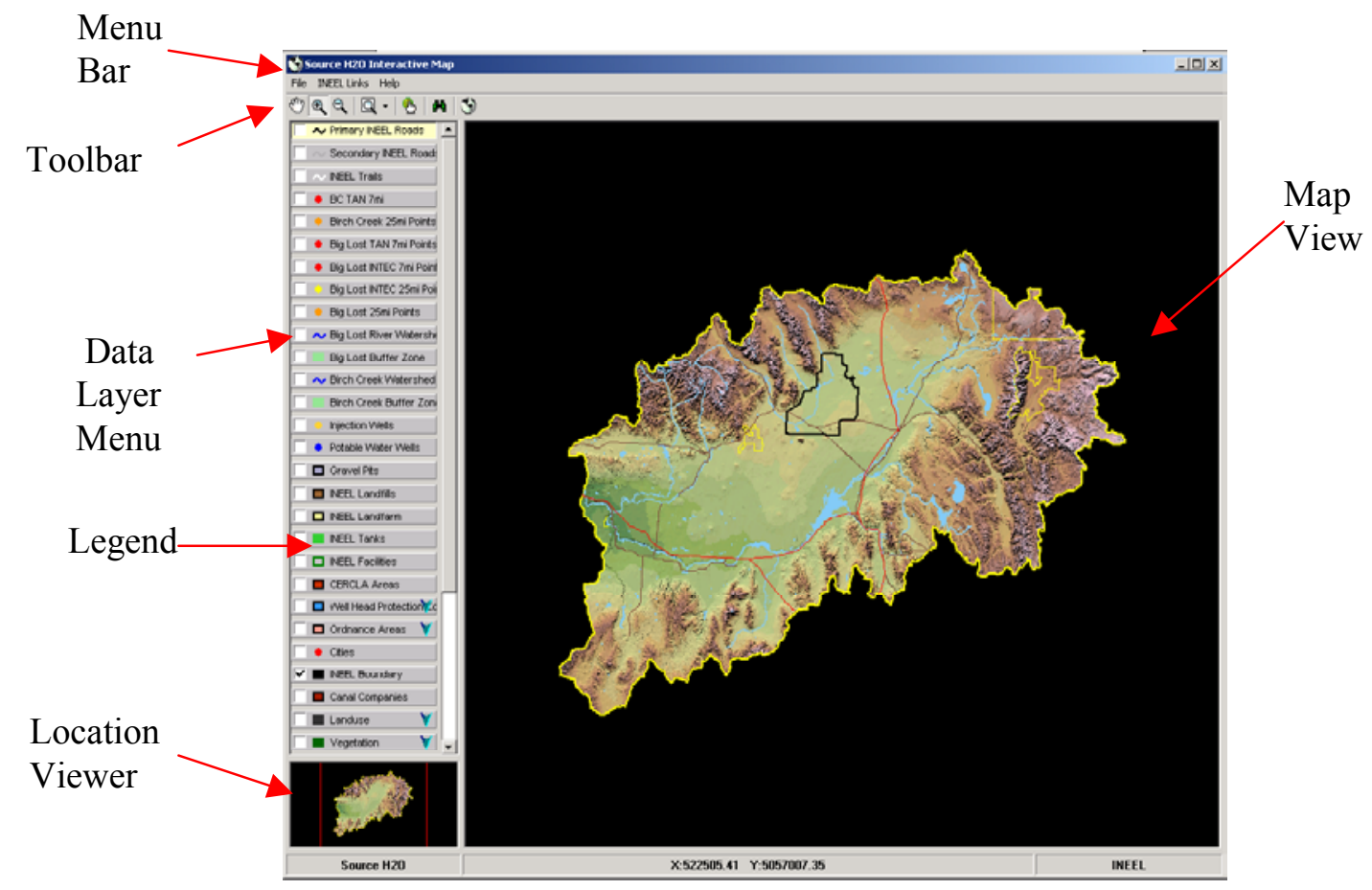

Figure 4. Source $\mathrm{H}_{2} \mathrm{O}$ desktop view. 


\section{MAP INTERFACE}

\subsection{Legend}

When initiated, Source $\mathrm{H}_{2} \mathrm{O}$ automatically loads all the data layers contained in the application into the map interface legend. However, only a few data layers are active on the map when the application loads. These data layers are indicated by a check mark in the box to the left of the data layer name (Figure 5). To activate other data layers, click inside the corresponding check box, and a check mark will appear indicating that layer's visibility on the map. To "remove" data layers from the map view, click in a check box of an active data layer (indicated by check mark), and the check mark will disappear, indicating that the layer is no longer active in the current map view.

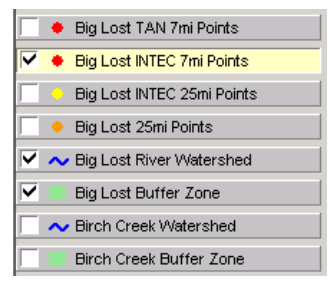

Figure 5. Active layers in legend indicated by a check mark.

The position of a data layer can also affect its visibility. For data active in the map viewer, the data layer positioned nearest the top of the Layer Menu will overlay data layers listed below it and may partially block them from view.

To change the position of a data layer in the data layer menu, select the desired layer by clicking and holding it and dragging it up or down in the legend. A bar will appear showing the position of the data layer as you move it (Figure 6).

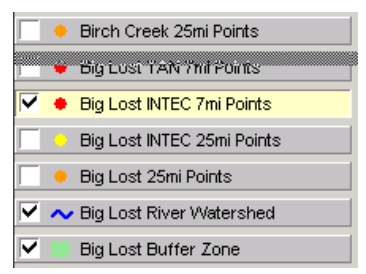

Figure 6. Example of moving the position of the Big Lost INTEC $7 \mathrm{mi}$ Points data layer in the legend. 
Data layers in this application may have legends associated with them (Figure 7). These data layers are indicated by a blue arrow to the right of the data layer name. To view the legends for these data layers, click on the blue arrow. A legend will then appear for that data layer. To hide the legend, click on the blue arrow again, and the legend will disappear.

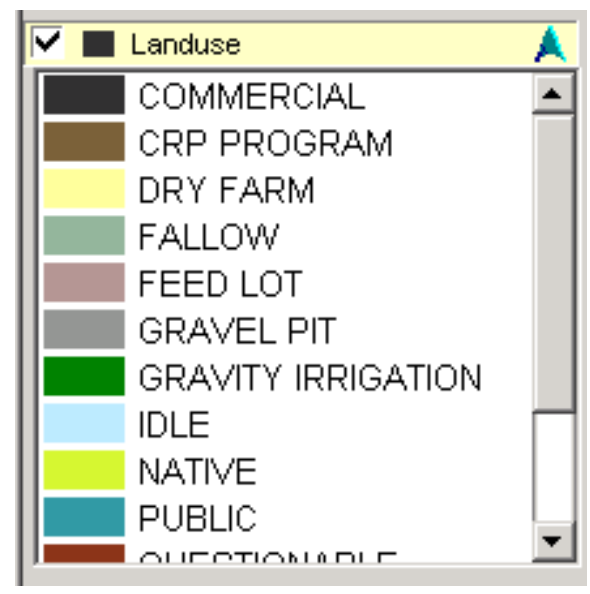

Figure 7. Example of legend.

To adjust the horizontal size of the legend, click and hold the right boundary of the legend, and move it either left or right.

\subsection{Spatial Navigation Tools}

The spatial navigation tools for the map viewer are in the toolbar above the data layer menu (Figure 8). These tools are used to zoom in and out, pan, and select viewing extents for the map view.

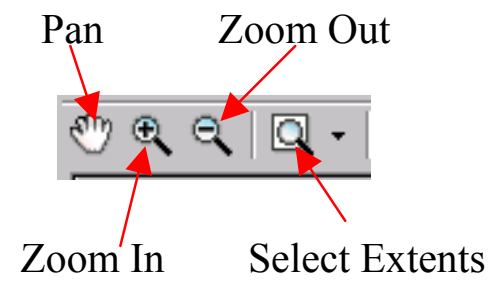

Figure 8. Spatial navigation toolbar.

To pan the map view, click on the Pan button on the toolbar to select it, and click and hold on the map to drag it to the desired position. 
There are two methods for zooming in on the map:

- Select the Zoom In button on the toolbar, left click on a location on the map to zoom in on. The map will zoom in incrementally with each click, centering on the location you click on.

OR

- Select the Zoom In button on the toolbar, place cursor on a location on the view, and left click and hold button down while moving cursor in the map view to drag a rectangle around the area of interest. The map will automatically zoom into the area within the rectangle and center it in the map view (Figure 9).

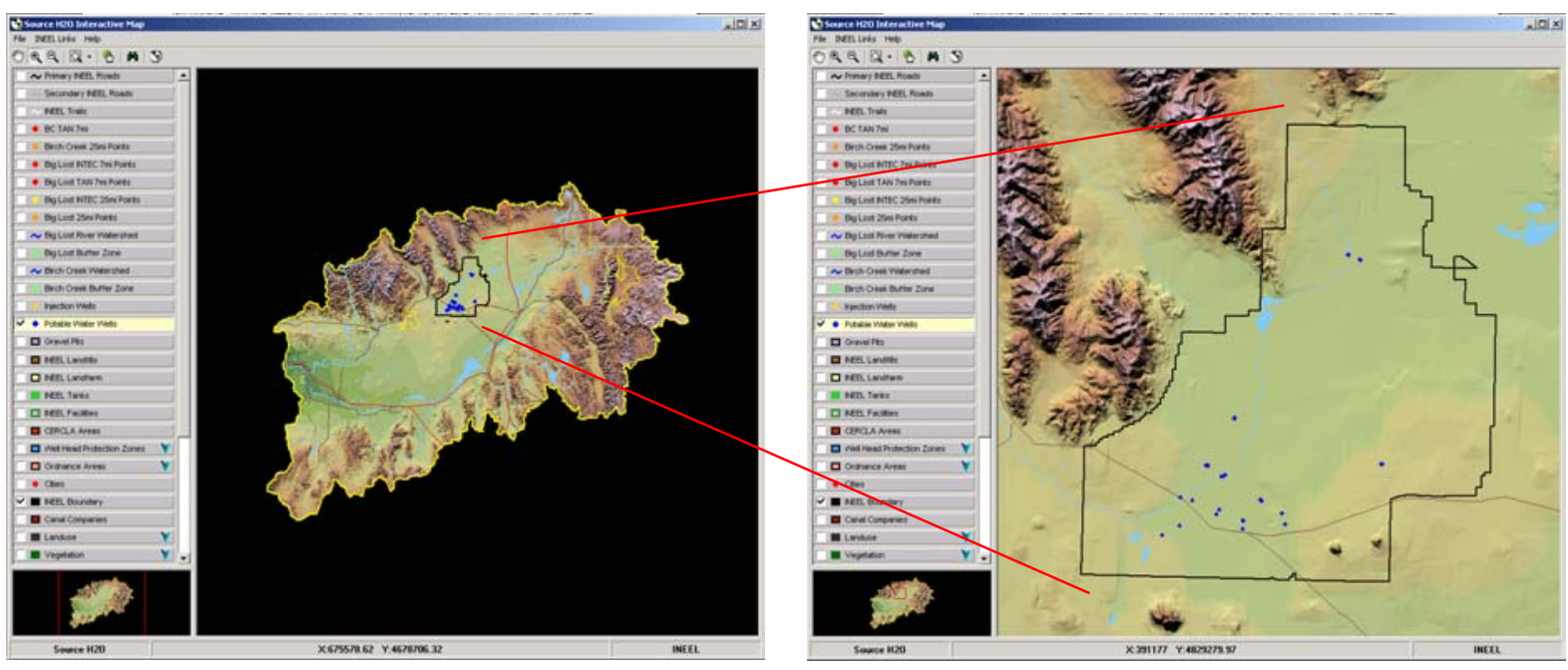

Figure 9. Example of zooming in to an area of interest by left clicking and drawing a rectangle around the desired area.

To zoom out on the map, select the Zoom Out button on the toolbar. Next, place the cursor on the area to zoom out from, and click the mouse. The map will zoom out incrementally with each click, centering the location you are clicking on in the center of the map view.

To return the original extent of the map, click the Select Extents button on the toolbar. This button also has other options associated with it that can be accessed through the drop down menu by clicking on the down icon to the right of the Select Extents button (Figure 10).

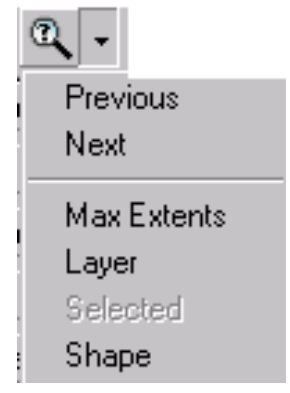

Figure 10. Drop down menu for map view extent options. 
This drop down menu allows you to instantly go back to the previous map extent by clicking the Previous option. If the Previous option is chosen, the Next option becomes available. When the Next option is clicked, it will take you back to the extent that was viewable before the Previous option was selected. The Max Extents option, when clicked, will take the map view out to the full extent of all currently active data layers. The Layer option allows you to zoom to the extent of a specific data layer that is selected in the data layer menu. To select a layer, click on its name in the data layer menu. That data layer will turn yellow in the legend to indicate it is selected (Figure 11).

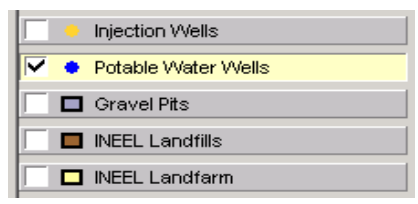

Figure 11. Example of Potable Water Wells as the selected data layer.

The Selected option is not available in this application. The Shape option allows you to go to the extent of a specific item (e.g., well, river segment, and building) by entering the GIS record number for that shape if it is known. A more intuitive procedure for locating a specific item is described in Section 5. 


\subsection{Location Viewer}

The location viewer is in the bottom left corner of the Source $\mathrm{H}_{2} \mathrm{O}$ display window (Figure 12). This Location Viewer allows you to see the general location on the INEEL site that may be zoomed into as indicated by a red box in the location viewer. In addition, you can change the area you are viewing. To change the area, click and hold the red box in the location viewer, and move it to a new location. This will automatically change the extent in the map view to contain the geographic area within the red box.

To size the location viewer, click and hold the right and top boundaries of the viewer, and drag them up or down and right or left.

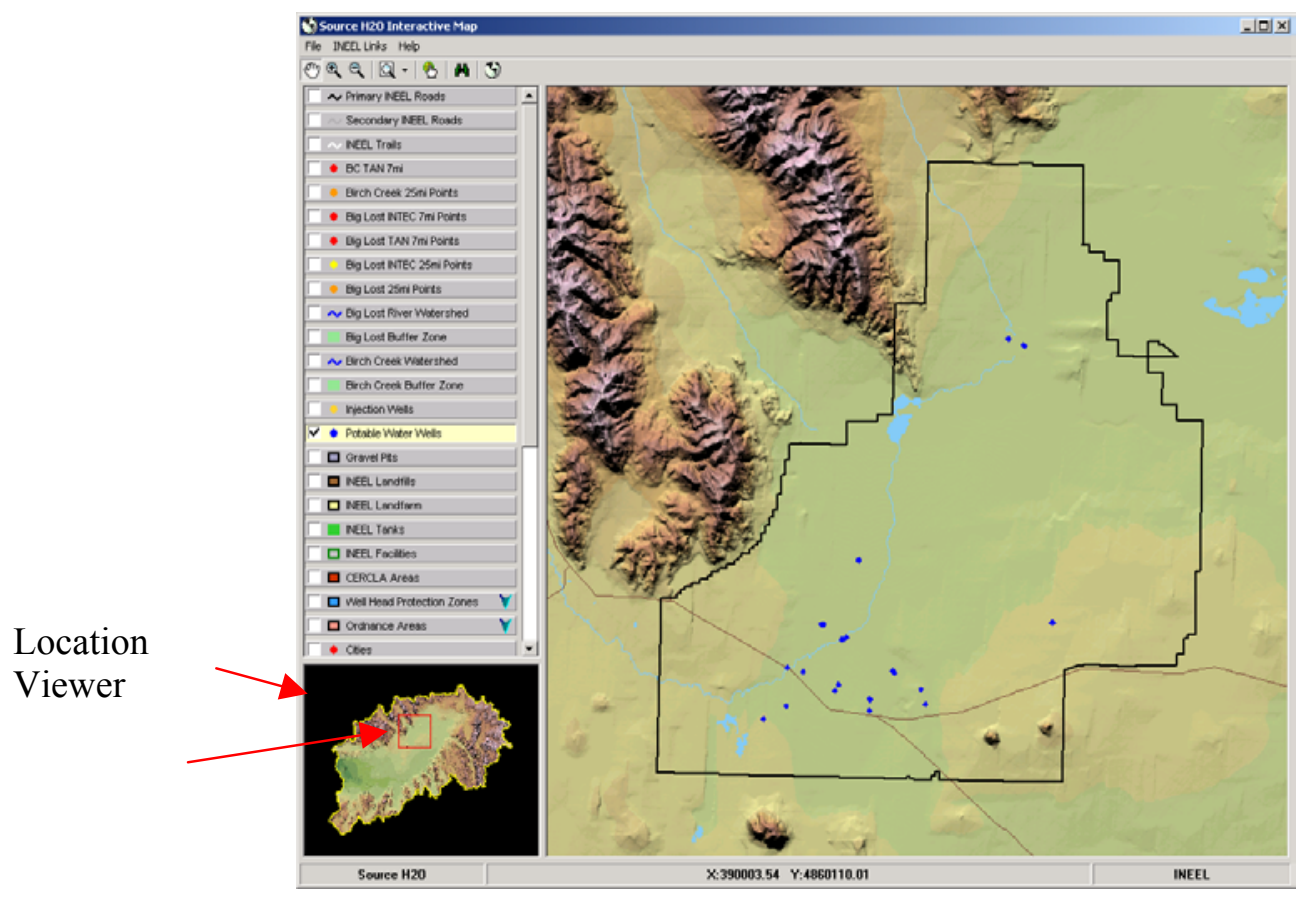

Figure 12. Location viewer. 


\section{INFORMATION TOOLS}

\subsection{Feature Identifier}

Another useful tool in the Source $\mathrm{H}_{2} \mathrm{O}$ application is the feature identifier function. The feature identifier function allows you to identify all features associated with the active data layers that fall within a set radius from the point of interest. You can then list those features' attribute information. To access the feature identifier function, click on the Feature Identifier button on the toolbar to select it (Figure 13).

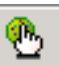

Figure 13. Feature identifier button.

Next, click on a point of interest in the map view. A yellow circle will be drawn showing the geographic area for which features will be identified. A window will activate that lists all the features found in that area. To view the attribute information associated with a specific feature, click the drop down menu in this window, and select a feature of interest. This feature will be highlighted in the map view, and its information will be available in the Attributes area of the Identify window (Figure 14).
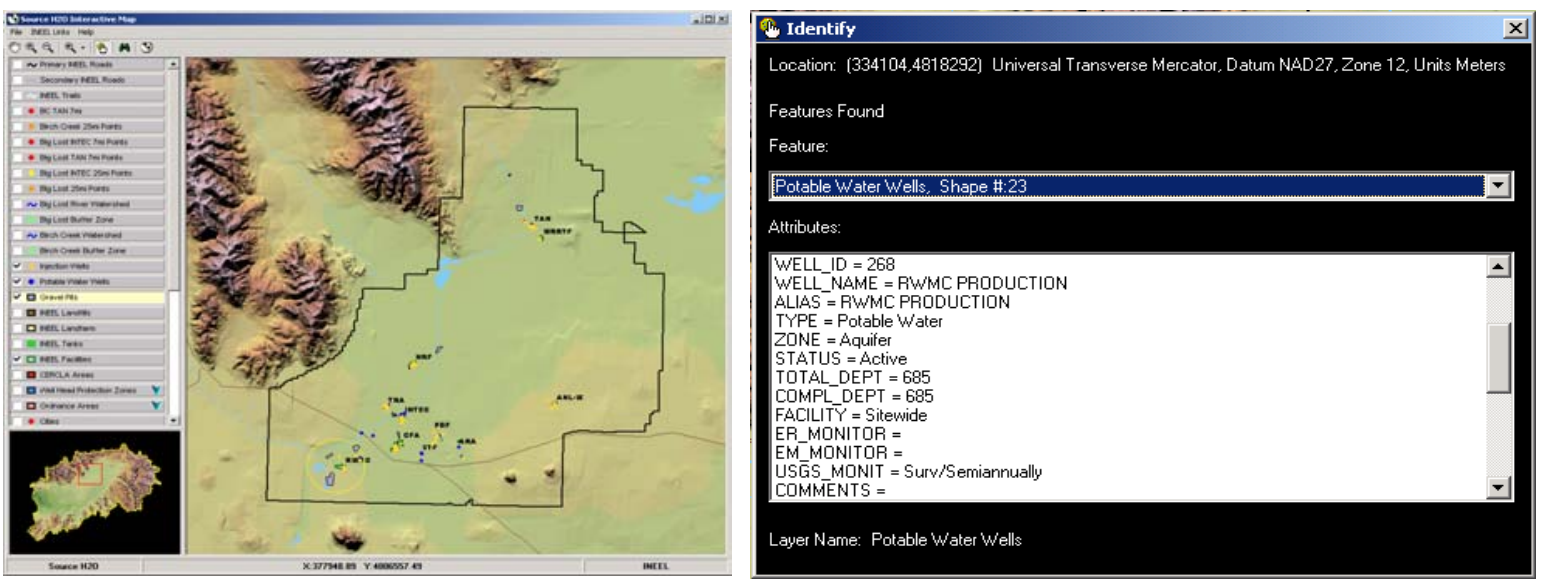

Figure 14. Displaying feature information using the feature identifier button.

Note: The search radius is fixed to a specific number of screen pixels. Thus, when zoomed out, the search radius will encompass a larger geographic area than when zoomed in on the map view.

\subsection{Search}

The search function allows you to type in any search string and identify and locate features associated with the data layers in the Data Layer Menu that contain that string somewhere within their data attributes. To access the search function, click on the Search button on the toolbar (Figure 15).

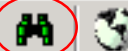

Figure 15. Search button. 
A Search window will then come up (Figure 16). Type a search string in Section 1, and either click the Search Active button or the Search All button in the window, depending on the level of search required.
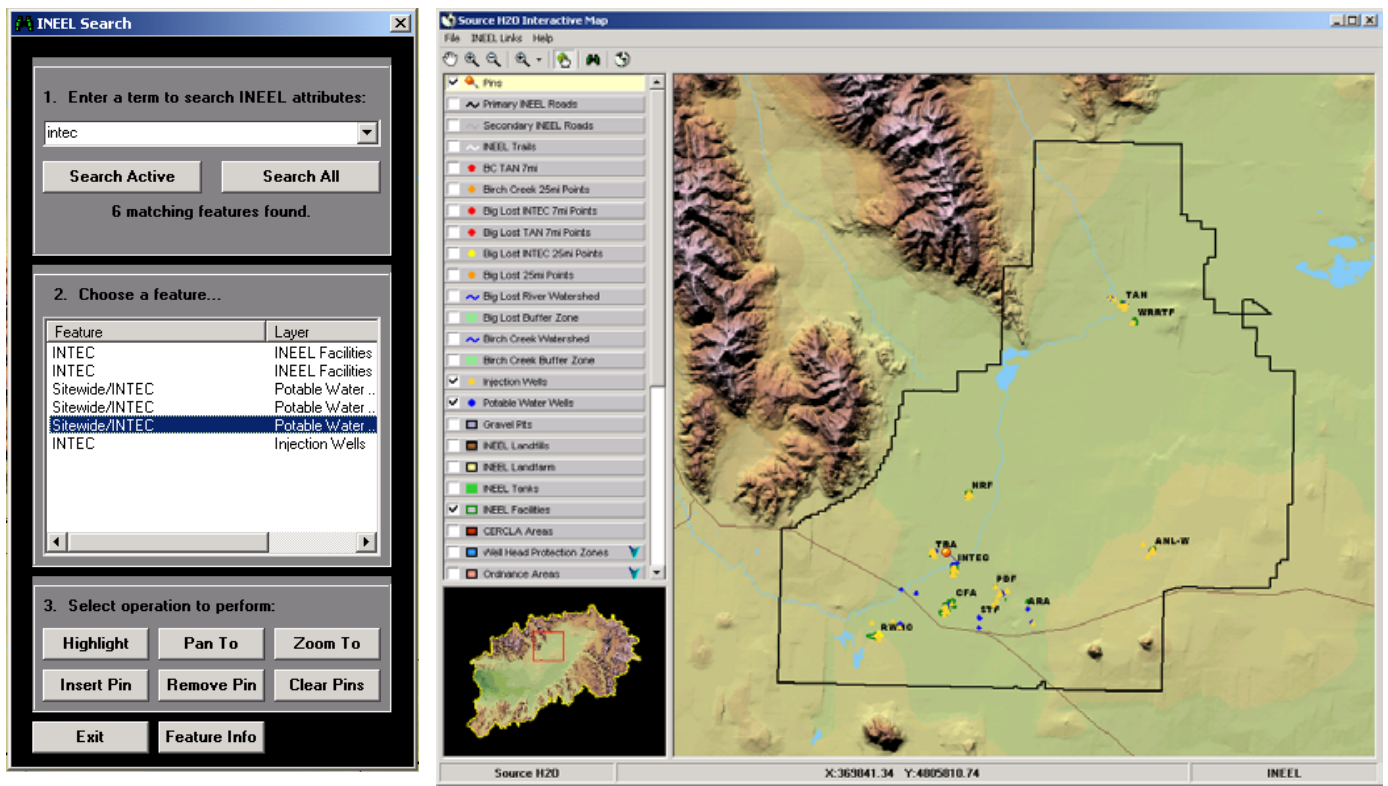

Figure 16. Locating features using the Search function.

The Search Active function searches only the information associated with the active data layers in the map view to determine if they contain the search string. This function can be used to refine searches by limiting them to specific data layers.

The Search All function searches all the information in the Source $\mathrm{H}_{2} \mathrm{O}$ application to determine if they contain the search string. This function is used for global searches to identify all features that may have the desired information associated with them.

Note: All previous search strings are stored in memory and can be accessed by clicking on the drop down menu in Section 1 of the Search window and selecting the string of interest.

All features associated with active data layers and that contain the search string somewhere within their attribute data will be listed in the table in Section 2. To expand the width of the data fields in the table, click and hold the bar to the right of the field name, and drag the field to the desired size.

From the search results list, select a feature of interest by clicking on it. Once selected, there are several options in Section 3 of the Search window for locating the feature in the map view (Figure 16).

\subsection{Operations Buttons}

The Highlight button flashes the selected feature and changes its color to yellow. When a new feature is selected, the color of the previously selected feature will return to normal (Figure 16). Highlighted items are cleared as described in Section 5.4.

The Pan To button centers the selected feature in the center of the map view keeping the same map viewing extent that was available prior to feature selection (i.e., it does not zoom in or out to the selected feature, but moves the current map view extent to include the feature in its center) (Figure 16).

The Zoom To button takes the map view to the extent of the selected feature (Figure 16). 
Note: This Zoom To function is not available for point features (i.e. wells, air monitoring points, etc.) To zoom into these features, use the Pan To function and then the Highlight function to locate the point of interest. Then use the Zoom In button on the toolbar to zoom into the feature.

The Insert Pin button places a pin in the center of the selected feature so that in can easily be located in the map view. To insert multiple pins, individually select other features in the list in Section 2 of the Search window, and click the Insert Pin button (Figure 16).

The Remove Pin button removes the pin associated with the selected feature in Section 2 of the Search window (Figure 16).

The Clear Pins button removes all pins in the map view (Figure 16).

The Feature Info button (Figure 16) accesses attribute information (Figure 17) for the selected feature from within the Search window.

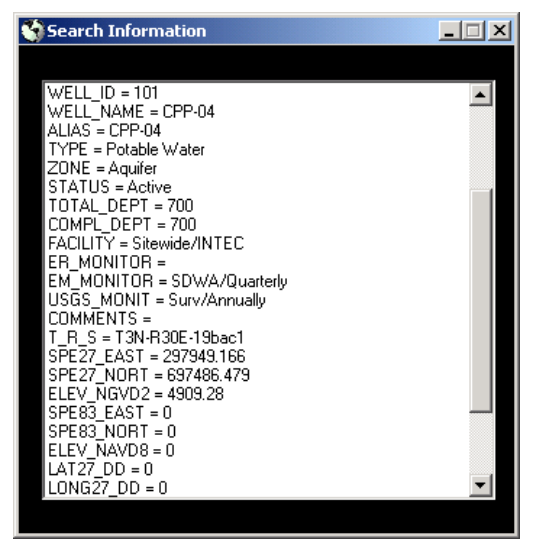

Figure 17. Displaying feature information using the Search button.

\subsection{Refresh}

To clear all highlighted features or pins from the map view, click the Refresh button on the toolbar (Figure 18).

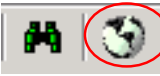

Figure 18. Refresh button. 